National Uranium Resource Evaluation

\title{
GEOLOGY AND RECOGNITION CRITERIA FOR SANDSTONE URANIUM DEPOSITS IN MIXED FLUVIAL-SHALLOW MARINE SEDIMENTARY SEQUENCES, SOUTH TEXAS
}

\section{FINAL REPORT}

BY: Samuel S. Adams

SAMUEL S. ADAMS AND ASSOCIATES

Boulder, Colorado

R. B. Smith

R. B. SMITH AND ASSOCIATES

Austin, Texas

January 1981

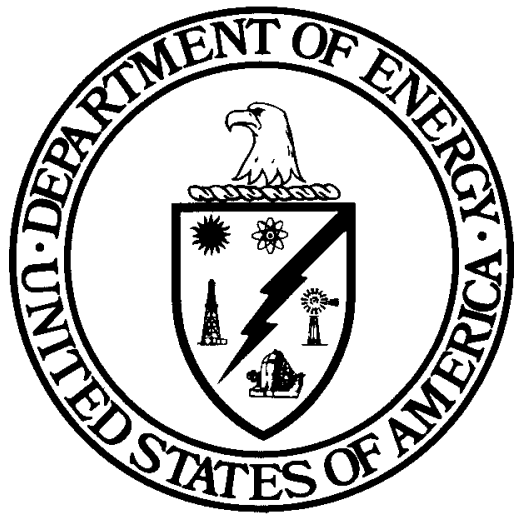

PREPARED FOR THE U.S. DEPARTMENT OF ENERGY Grand Junction Office, Colorado 
This report is a result of work performed by Samuel S. Adams and Associates through a Bendix Field Engineering Corporation Subcontract, as part of the National Uranium Resource Evaluation. NURE is a program of the U.S. Department of Energy's Grand Junction, Colorado, Office to acquire and compile geologic and other information with which to assess the magnitude and distribution of uranium resources and to determine areas favorable for the occurrence of uranium in the United States.

This report was prepared as an account of work sponsored by an agency of the United States Government. Neither the United States Government nor any agency thereof, nor any of their employees, makes any warranty, express or implied, or assumes any legal liability or responsibility for the accuracy, completeness, or usefulness of any information, apparatus, product, or process disclosed, or represents that its use would not infringe privately owned rights. Reference herein to any specific commercial product, process, or service by trade name, trademark, manufacturer, or otherwise, does not necessarily constitute or imply its endorsement, recommendation, or favoring by the United States Government or any agency thereof. The views and opinions of authors expressed herein do not necessarily state or reflect those of the United States Government or any agency thereof. 


\section{DISCLAIMER}

Portions of this document may be illegible in electronic image products. Images are produced from the best available original document. 


\section{GEOLOGY AND RECOGNITION CRITERIA FOR \\ SANDSTONE URANIUM DEPOSITS IN MIXED FLUVIAL-SHALLOW MARINE SEDIMENTARY SEQUENCES, SOUTH TEXAS}

FINAL REPORT

Samuel S. Adams
Samue1 S. Adams and Associates $95 / 3027$

and

R. B. Smith

corp.

R. B. Smith and Associates

9513206

December 1980

PREPARED FOR THE U.S. DEPARTMENT OF ENERGY

GRAND JUNCTION OFFICE, COLORADO

UNDER CONTRACT NO. DE-AC13-76GJ01664

SUBCONTRACT NO. 79-296-S

This book was prepared as an z c rount of work sponsared by an agency of the United States Government

Netither the United States Government nur any azency thereot nor aniv of their employees makes any

wartanty express or impled or assumes any legal liabli ty or ressonsibility for the accuracy

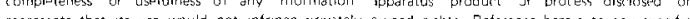

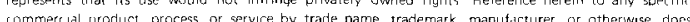

commercial product process or service by trade hame rodemank mank deturer or otherwise does 
○

- 
LIST OF FIGURES . . . . . . . . . . . . . . . . . . 5

LIST OF TABLES .......................... . . . . . 7

LIST OF PLATES . . . . . . . . . . . . . . . . . . . 8

SUMMARY . . . . . . . . . . . . . . . . . . . . . . . . 9

Source of Uranium . . . . . . . . . . . . . . . . . . 9

Host Rocks . . . . . . . . . . . . . . . . . 10

Reductants ........................... . 11

Alteration ............................ . 12

Ore Habits . . . . . . . . . . . . . . . . . . . . 12

Recognition Criteria..................... . 13

Reflections and Continuing Studies.............. . 14

Potential for South Texas-type Deposits. . . . . . . . . . . . 14

INTRODUCTION . . . . . . . . . . . . . . . . . 15

Objectives . . . . . . . . . . . . . . . . . 16

Source of Data........................ 17

Acknowledgements . . . . . . . . . . . . . . . . . 18

REGIONAL GEOLOGIC SETTING . . . . . . . . . . . . . . . . . 19

Brief Geologic History . . . . . . . . . . . . . . . . 23

STRATIGRAPHY AND SEDIMENTOLOGY . • . . . . . . . . . . . . . . 25

Midway Group . . . . . . . . . . . . . . . . . . . 25

Wilcox Group . . . . . . . . . . . . . . . . . . 25

Claiborne Group .......................... 27

Carrizo Sand ........................ 27

Reklaw Formation ..................... 28

Queen City Formation .................... 29

Weches Formation ................... 30

Sparta Formation ................. 30

Cook Mountain Formation . . . . . . . . . . . . 31

Yegua Formation ..................... 32

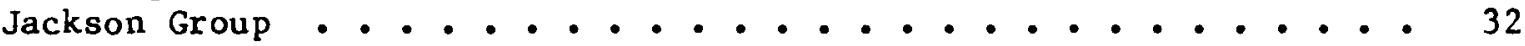

Frio Formation .......................... 34

Catahoula Formation ................... 35

Fleming Group .......................... 37

Oakville Formation .................. 37

Fleming Formation...................... 38

Citronelle Group .......................... 39

Goliad Formation .................... 39

Willis Formation .................. 41

Houston Group ... . . . . . . . . . . . . . . . . 43

URANIUM DEPOSITS . . . . . . . . . . . . . . . . . . . 4 45

Introduction .......................... 45

Deposits in the Jackson Group .................. . 51

Brysch Uranium Mine, Karnes County, Texas .......... 55

Deposits in the Catahoula Formation . . . . . . . . . . 55

Deposits in the Oakville Formation . . . . . . . . . . . 62

Deposits in the Gollad Formation . . . . . . . . . . . . 68

SOUTH DUVAL COUNTY MINERAL TREND . . . . . . . . . . . . . . 73

Introduction . . . . . . . . . . . . . . . . . . . 73 
Deposits in the Catahoula Formation . . . . . . . . . . 73

Deposits in the Oakville Formation.............. 79

Deposits in the Goliad Formation . . . . . . . . . . . 81

ORIGIN OF THE DEPOSITS . . . . . . . . . . . . . . . . 83

Source of Uranium ..................... 83

Host Rocks ....................... . . . 84

Mechanism of ore Formation . . . . . . . . . . . . . 84

Mega-Channel Systems . . . . . . . . . . . . . . 85

Working Model . . . . . . . . . . . . . . . . 89

RECOGNITION CRITERIA ...................... 95

Introduction . . . . . . . . . . . . . . . . . 95

Evaluation of Recognition Criteria . . . . . . . . . . 98

Description of Recognition Criteria . . . . . . . . . . . 104

Tectonic, Structural, and Regional Geologic Setting . . . . . 104

Tectonic Setting ............... 104

Structural Setting ................ 105

Sediment Dip.................... 105

Sediment Provenance .............. 105

Uraniferous Province................. 106

Sedimentary Sequence ................. 106

Age . . . . . . . . . . . . . ....... 106

Thickness .................... 106

Area . . . . . . . . . . . . . . . 107

Host Sediments . . . . . . . . . . . . . . . 107

Volcanic Ash or Bentonite . . . . . . . . . . 107

Color ..................... 108

Depositiona1 Environment . . . . . . . . . . 108

Sand-Shale Relations ................ 108

Host Sandstone ................... 109

Thickness ..................... 109

Area ...................... 110

Permeability ................ 110

Depositional Environment ............. 110

Composition .................. 111

Alteration and Mineralization . . . . . . . . . 112

Alteration ..................... 112

Mineralization............... 113

REFLECTIONS AND CONTINUING STUDIES . . . . . . . . . . . . . . . 115

POTENTIAL FOR SOUTH TEXAS-TYPE DEPOSITS IN THE UNITED STATES • • • • • • 117

South Texas Uranium Region . . . . . . . . . . . . . . . . 117

APPENDIX: ESTIMATION OF GEOLOGIC FAVORABILITY FOR THE OCCURRENCE OF

SOUTH TEXAS-TYPE DEPOSITS . . . . . . . . . . . . . . . . . . 119

Introduction . . . . . . . . . . . . . . . . . . . . . 119

Calculation of Estimated Favorability . . . . . . . . . . . 119

Completeness and Confidence of Geologic Data . . . . . . . 121

Interpretation of Results . . . . . . . . . . . . . . . 122

Examples of Favorability Estimates for Three Areas . . . . . . . 125

SELECTED REFERENCES . . . . . . . . . . . . . . . . . . 135 
Number

$\underline{\text { Page }}$

1. Location map for the South Texas Uranium Region and certain neighboring geologic provinces.

2. Distribution of depositional environments at six times during the Tertiary, South Texas (modified from Guevara and Garcia, 1972; and Ricoy and Brown, 1977).

3. Cenozoic stratigraphy, global sea level changes, and principal uranium-bearing units, South Texas (modified from Berggren and Van Couvering, 1974; and Vail et al, 1977b).

4. Diagrammatic stratigraphic cross section from the Rio Grande Embayment to the Houston Embayment, South Texas (modified from Guevara and Garcia, 1972; Galloway, 1977; and Wilbert and Templain, 1978).

5. Schematic cross section depicting the development of growth faults, South Texas (modffied from Bruce, 1972).

6. Schematic cross section depicting the accumulation of hydrocarbons and movement of $\mathrm{H}_{2} \mathrm{~S}$ associated with growth faults, South Texas.

7. Diagrammatic cross section showing the migration paths of fresh ground water and fault-related $\mathrm{H}_{2} \mathrm{~S}$, South Texas (modified from Baker, 1979).

8. Schematic cross sections showing the sequence of events leading to the formation of uranium deposits related to faultderived $\mathrm{H}_{2} \mathrm{~S}$, South Texas. $\mathrm{H}_{2} \mathrm{~S}$ introduction likely preceded and followed roll-front formation but was not synchronous.

9. Uranium deposits and net-sand isolith for Tordilla Sandstone Member of Upper Jackson Group, Western Karnes County, South Texas. Depositional environments identified include distributary channel (A), cuspate delta (B), coastal barrier-bar (C), tidal inlet (D), and lagoon (E) (modified from Galloway et al, 1979a).

10. Geologic map showing parts of Karnes County and locations of uranium mines (from Eargle et al, 1975).

11. Map and cross section for the Brysch uranium deposit, Whitsett Formation, Karnes County, South Texas (modified from Dickinson and Sullivan, 1976).

12. Schematic reconstruction of Gueydan depositional environments (modified from Galloway et a1, 1979a). 
13. Geologic setting of the Washington-Fayette deposit, Catahoula

Formation, showing roll-front uranium mineralization within the crevasse splay sand body (modified from Galloway and Ka1ser, 1979).

14. Diagrammatic cross section across the roll front in the Washington-Fayette deposit. Location of cross section indicated in Figure 13 (modified from Galloway and Kaiser, 1979).

15. Geologic setting of the House-Seale deposit, northern Live Oak County. Deposit occurs in crevasse splay facles that have been reduced by north-flowing $\mathrm{H}_{2} \mathrm{~S}$-bearing waters (modified from Galloway and Kalser, 1979).

16. Geologic map of the Ray Point district showing approximate outlines of urantum deposits, South Texas (modifled from Galloway et al, 1979a).

17. Cross section through the Zamzow deposit, Ray Point uranium district, South Texas. Location of cross section shown on Figure 16 (modified from Galloway et al, 1979a).

18. Distribution of uranium deposits in the Oakville Formation, South Texas (Galloway et al, 1979a).

19. Cross section through the Lamprecht uranium deposit, Ray Point district, showing roll front and alteration, South Texas (modified from Goldhaber et al, 1979).

20. Map and cross section showing relations of various fluvial facies in the Oakville Sandstone (from Klohn and Plckens, 1970; modified by Eargle et al, 1975).

21. Cross sections through the roll front in the Felder uranium mine, Live Oak County, South Texas (from Klohn and Pickens, 1970; modified by Eargle et a1, 1975).

22. Schematic cross section of the Palangana Dome and associated uranium deposits, Duval County, Texas.

23. Schematic cross section (B-B') across the South Duval County Mineral Trend.

24. Cross section of the Benavides deposit showing the distribution of the major chemical zones. Sampled portions of core are shown in heavy lines (modified from Reynolds and Goldhaber, 1978).

25. Schematic cross section (C-C') across the South Duval County Mineral Trend. 
26. Schematic cross section ( $D-D^{\prime}$ ) across the South Duval County Mineral Trend.

27. Schematic cross section (E-E') across the South Duval County Minera1 Trend.

28. Distribution of molybdenum, selenium, vanadium, pyrite, and uranium in some roll-type deposits (from Harshman, 1974; modified by Harshman and Adams, 1981).

29. Composite Eh-pH diagram for the principal elements in rol1-type uranium deposits and for copper. Solid phases are underlined (from Harshman, 1974; modified by Harshman and Adams, 1981).

30. Schematic cross section across the South Texas Central Plain showing the Catahoula Formation resting with angular unconformity on older Tertiary sediments.

31. Simplified location map for uranium mines, the surface projection of the Cretaceous Edwards Carbonate Reef Trend and deep Edwards fault trend, and the Cretaceous S11go shelf edge (modified from Goldhaber et al, 1979).

32. Schematic cross section across a roll front showing relations for secondary reduction and subsequent partial re-oxidation of the altered tongue for a fault-derived sulfide-bearing sandstone. Pathways of earlier $\mathrm{H}_{2} \mathrm{~S}$ introduction are indicated.

33. Recognition criteria net for the South Texas-type uranium deposits.

34. Example of the dssignment of weights to recognition criteria using the four criteria that determine Composition for the Host Sandstone.

35. Schematic relation between calculated favorablitity for South Texas-type deposits and the chances of a deposit belng present within the area evaluated.

LIST OF TABLES

Number

1. Estimates of the values (scale +100 to -100 ) for the recognition criteria for South Texas-type deposits for establishing the favorability of the criteria above them in the recognition criteria net (see Fig. 33).

2. Hypothetical recognition criteria values, from four Imaginary field areas, for the four criteria that determine Host Sandstone Composition. 


\section{PLATES}

(Pocket Inside Back Cover)

Number

I. Uranium deposits of South Texas and the South Texas Mineral Trend

II. Structural map of South Texas

III. Geologic map of Cenozolc rocks in South Texas

IV. Cenozoic geologic column of South Texas

V. Petroleum and natural gas in South Texas

VI. Channel sands in the Jackson Group, South Texas

VII. Channel sands in the Catahoula Formation, South Texas

VIII. Channel sands in the Oakville Formation, South Texas

IX. Channel sands in the Goliad Formation, South Texas

X. South Duval County Mineral Trend, South Texas

XI. Schematic northwest-southeast cross section ( $\left.A-A^{\prime}\right)$ of the South Duval County Mineral Trend

XII. Present fluvial drainage systems in South Texas

XIII. Mega-channel sand systems in South Texas 
Uranium deposits in the South Texas Uranium Region are classical roll-type deposits that formed at the margin of tongues of altered sandstone by the encroachment of oxidizing, uraniferous solutions into reduced aquifers containing pyrite and, in a few cases, carbonaceous plant material. Study, during the past twenty years, of the wel1-exposed rol1-type districts in Wyoming has substantially aided geologic interpretation and exploration in South Texas. The roll-type model as an ore-forming process is widely accepted and is the subject of a companion report (Harshman and Adams, 1981).

Many of the uranium deposits in South Texas are strikingly dissimilar from the roll fronts of the Wyoming basins in some important characteristics. The host sands for many of the deposits contain essentially no carbonaceous plant material, only abundant disseminated pyrite. Secondly, many of the deposits do not occur at the margin of altered (ferric oxide-bearing) sandstone tongues but rather occur entirely within reduced, pyrite-bearing sandstone. Excellent studies by Goldhaber and co-workers have supported early suggestions that the abundance of pyrite within the sands probably reflects the introduction of $\mathrm{H}_{2} \mathrm{~S}$ up along faults from hydrocarbon accumulations at depth. Such introductions before ore formation prepared the sands for roll-front development, whereas post-ore introductions produced re-reduction of portions of the altered tongue, leaving the deposit suspended in reduced sandstone. Evidence from three deposits suggests that ore formation was not accompanied by the introduction of significant amounts of $\mathrm{H}_{2} \mathrm{~S}$ (Busche et al, in press).

As the principal objective of this study is to identify the most useful geologic characteristics, referred to as recognition criteria, and develop a method for their systematic use in resource studies and exploration, the important geologic observations on the uranium deposits of South Texas are briefly summarized below.

\section{Source of Uranium}

(1) The source of uranium in the South Texas deposits is presumed by most investigators to have been in the associated tuffaceous sediments. There is no convincing evidence that this is the case, although certain circumstantial arguments tend to support this hypothesis.

(2) Tuffaceous and bentonitic volcaniclastic sediments, principally in the Catahoula Formation, but also in the Jackson Group and the Oakville Formation, are present as they are in all major roll-type districts in the United States. Similar volcanic-rich sediments are also associated with other major types of sandstone deposits such as the Grants Uranium Region in northwestern New Mexico and the Triassic and Morrison uranium districts of the Colorado Plateau. These relations provide strong circumstantial evidence that these volcaniclastics were the source for the uranium. We favor such a source, which is supported by low uranium content and high thorium:uranium ratios for the Catahoula Formation. 
(3) Most uranium districts can be shown to occur within or be associated with regions that contain anomalous concentrations of uranium. These concentrations may occur as greater than normal concentrations within granites, volcanic sequences, or, as is the case with certain Precambrian deposits, anomalous uranium concentrations in basement metamorphic rocks. Both uraniferous granites and volcanic rocks are present in the vicinity of the Wyoming basins. The volcanic components of the sediments in the South Texas area are belleved to have been derived from volcanic centers in the Big Bend ragion. Rocks in this area have been shown to contain anomalous concentrations of uranium, hence, may have provided adequate amounts of uranium to the South Texas region either in volcanic detritus or ground waters. The importance of a uraniferous province to the formation of uranium deposits seems logical. It is not certain, however, whether normal concentrations of uranium in source rocks are adequate to form deposits or whether those source rocks must contain anomalous concentrations of uranium.

(4) Uranium deposits that occur in sediments other than the tuffaceous Catahoula Formation, or its immediately overlying or underlying sands, are within hosts that are down hydrologic gradient from the Catahoula. This suggests that these tuffaceous rocks supplied the uranium which ground waters have subsequently transported to reducing environments.

Host Rocks

(1) All of the uranium deposits in South Texas occur in proximity to permeable sandstones which range in composition from quartz arenites to arkoses. The sandstones are of primary importance as an aquifer which permitted the transport of uraniferous ground waters. The composition of the sandstone is indicative of depositional environment but is otherwise not important provided most clasts are resistant to alteration, i.e., quartz and feldspar. Deposits in the Jackson Group, for example, occur in quartz arenites deposited in a marine beach and bar environment, whereas the balance of the deposits in South Texas are largely arkoses and subarkoses deposited principally in fluvial environments.

(2) Sand bodies of sufficient permeability and transmissivity deposited in a variety of types of depositional environments occur in complex relations one to another. Productive sand bodies include point bars, lateral bars, and crevasse splays deposited in fluvial environments, and barrier bars and offshore bars deposited in shore facies. Associated unproductive finer grained sediments include silt-rich crevasse and floodplain deposits and lagoonal, swamp, and lacustrine sediments. Relations between these permeable and nonpermeable sediments vary both laterally and vertically in response to changes in and migrations of sedimentary environments. This produces a complex sedimentary package in which it is more difficult to project ground water flow patterns than in the less complex sedimentary sequence of, for example, the Wyoming basins. Ironically this very complexity has contributed to the slower exploration of the South Texas region, thereby preserving considerably more exploration potential than remains in most Wyoming basins. 
(3) The depositional environments and relations between depositional environments exert great effect on the shape, orientation, and continuity of mineralization. The distribution of ore trends, for example, is controlled by broad-scale sedimentary features such as the mega-channel systems associated with the dip-oriented ore trends in the South Duval County Mineral Trend. The strike-oriented roll fronts in the beach sands of the Jackson Group reflect a different broad-scale sedimentary feature.

\section{Reductants}

(1) In marked contrast to other types of sandstone uranium deposits, the uranium deposits in South Texas, with the exception of the deposits in the Jackson Group and possibly the Carrizo Sand, contain negligible quantities of carbonaceous material. The deposits in the Wyoming basins and the Grants Uranium Region contain, respectively, detrital and redistributed humic material. Most of the host sands in Texas, however, were apparently strongly oxidized at or shortly after burial, essentially destroying the indigenous carbonaceous material. The deposits of the Jackson Group are atypical, as the roll fronts occur in sands rich in detrital plant material.

(2) The common reductant in the sands of the Catahoula, Oakville, and Goliad Formations is finely dispersed pyrite. The following observations suggest that $\mathrm{H}_{2} \mathrm{~S}$ was introduced into the aquifers along faults, presumably from hydrocarbon reservoirs at depth: (a) the spatial distribution of these pyritiferous sands with respect to faults, (b) sulfur isotope data, (c) the occurrence of some reduced sandstones entirely within oxidized sandstone, and (d) the virtual absence of carbonaceous material. Hydrologic and mineralogic arguments favor early formation for the uranium deposits, and hence the introduction of $\mathrm{H}_{2} \mathrm{~S}$ to form pyrite immediately after burlal, but prior to ore formation, is critical. The absence of uranium deposits over wider areas of otherwise favorable mega-channel sands may indicate that the sands escaped reduction by $\mathrm{H}_{2} \mathrm{~S}$.

(3) Some of the sulfides in the host sandstones are isotopically heavy, and it has been proposed that the $\mathrm{H}_{2} \mathrm{~S}$ which led to their formation was probably derived from the deep Edwards Limestone ofl and some gas fields. Other sulfides in the same host sands contain isotopically light sulfur. It has been suggested that in these cases the sulfide was derived from bacterial sulfate reduction in shallow aquifers promoted by the seepage of organic matter from Tertiary hydrocarbon deposits. It is likely that all the permutations of these processes have not yet been seen. The introduced $\mathrm{H}_{2} \mathrm{~S}$ and organic matter were apparently important to ore formation.

(4) The destruction of carbonaceous material during or shortly after sedimentation is not believed important to ore formation provided that $\mathrm{H}_{2} \mathrm{~S}$ is introduced into the sands shortly after deposition and prior to the diagenetic release of uranium. If the sands are widely oxidized, then the introduction of $\mathrm{H}_{2} \mathrm{~S}$ is essential for the ore-forming process. 


\section{Alteration}

(1) Many deposits in South Texas are at the edge of oxidized sandstone tongues as is characteristic of roll-type deposits. Excellent examples are the deposits of the Jackson Group. The general mineralogic and geochemical characteristics of the unaltered downdip and altered updip (oxidized with respect to iron) sands are similar to those of Wyoming roll-type deposits.

(2) The deposits of the South Duval County Mineral Trend similarly occur at the edge of altered sandstone tongues. Mineralogic studies of one deposit have identified two alteration zones within the oxidized tongue; the first is well updip from the roll fronts and contains $\mathrm{Fe}-\mathrm{Ti}$ oxides that are in various states of oxidation. The second extends for a variable distance back updip from the roll front and contains vestiges of 1 lmenite and magnetite. In the reduced sands downdip from the roll front, $\mathrm{Fe}-\mathrm{Ti}$ oxides have also been completely destroyed, in part through replacement by pyrite. Studies have indicated that the latter two zones were invaded by $\mathrm{H}_{2} \mathrm{~S}$-bearing solutions resulting in the alteration of $\mathrm{Fe}-\mathrm{Ti}$ oxides to pre-ore-stage pyrite. The subsequent introduction of oxidizing solutions into these sulfide-bearing sands oxidized the pyrite and produced the geometric relations as they are observed today. Recognition of the distribution of sulfidized sandstones is, therefore, an important aspect of resource studies and exploration in South Texas.

(3) Some roll-type deposits occur entirely within reduced (sulfide-bearing) sandstone, thus eliminating the oxidation-reduction boundary as a simple exploration criterion. Multiple post-ore introductions of $\mathrm{H}_{2} \mathrm{~S}$ interspersed with periods of oxidation may have locally produced a complex series of alteration zones and even multiple roll fronts. Knowledge of these possible relations should help in the design of field programs.

(4) In the deposits studied in the Catahoula and Oakville Formations, marcasite occurs in a broad zone downdip from the roll fronts. This marcasite has been interpreted to have formed during ore formation by the oxidative destruction of pre-ore-stage pyrite in sulfide-rich, carbonaceous-poor systems. It is a guide, therefore, for interpreting mineralization data and ore-related processes.

\section{Ore Habits}

(1) As with other roll-type deposits, the shape of the ore rolls in South Texas is controlled by the transmissivity of the host rock which reflects the depositional environment in which the sand accumulated. Cuspate or C-shaped roll forms that are concave up the hydrologic gradient are commonly present in uniform sands bounded by impervious shales or siltstones. In many South Texas deposits, however, the complex interrelations between sand units of variable permeability and units of very low permeability produce deposits of complex geometry. Sedimentologic features, therefore, are the first and most important controls on the regional and detalled shapes of the deposits. 
(2) The distribution of indigenous and introduced reductants similarly exerts a strong influence on the distribution and habit of uranium rolls. In carbonaceous-rich sediments such as those of the Jackson Group, roll fronts have formed where oxidizing solutions gain access to carbonaceous-rich sands. The shape of the deposits is determined largely by the shapes of these sand bodies and their relations with adjacent and enclosing finer grained sediments. The abundance and distribution of carbonaceous material also seem to exert control on the shape of the roll fronts. Large concentrations of carbonaceous material in permeable sands tend to form high-grade uranium concentrations with sharp roll-front boundaries. Dispersed low-level concentrations tend to form diffuse lower grade roll-type deposits. Carbonaceousrich sediments adjacent to permeable sands, such as lignite horizons, commonly develop concentrations of uranium at the boundary of the sandstone, but the impervious nature of the lignites has produced mineable grades and thicknesses only locally.

(3) The positions of the large deposits in the South Duval County Mineral Trend, for example the Holiday-E1 Mesquite deposit, suggest particular relations which may have contributed to the formation of these unusually large deposits. The deposits are elongate parallel to the axis of ground water movement and occur at the boundary between oxidized sandstone and $\mathrm{H}_{2} \mathrm{~S}$-reduced sandstone. The presence of the deposit parallel to, rather than perpendicular to, the direction of ground water flow suggests that large volumes of water flowed tangentially past reduced sandstone rather than directly through the roll front. This geometric setting may have permitted exposure of large volumes of uraniferous water to the roll front, leading to the deposition of considerable uranium against the pyrite-rich sandstone. The occurrence of oxidized sands well past these major deposits might cause them to be overlooked if conventional roll front exploration methods were used. The reduced and subsequently oxidized sands in proximity to these deposits should, however, contain neither Fe-Ti oxides nor their oxidation products; hence studies of alteration assemblages are important guides to evaluation and exploration.

\section{Recognition Criteria}

(1) A method is presented for organizing geologic observations into what we refer to as recognition criteria. The use of such observations to draw inferences about favorability has been employed for decades, but in an informal way. Informal methods will continue to be part of any interpretive process, and this is appropriate. We see merit, however, in attemp.ting to identify those geologic criteria that are the most important guides to deposits of the South Texas type and establish at least their relative importances.

(2) Recognition criteria are presented for the appraisal of areas favorable for the occurrence of the South Texas-type deposits. Each criterion has various conditions or states of relative favorability and unfavorability, and most incorporate reference to several types of geologic observations. The criterla are neither new nor have they been developed for geologists intimately familiar with the South Texas deposits. Rather, they lend some consistency to studies performed by geologists responsible for resource investigations or exploration personnel becoming familiar with South Texas. 
(3) The relative importances assigned to the various recognition criteria are subjective judgements, and we would have little argument with comparable but different numbers. On the other hand, to accept substantially different values would require, for us, the presentation of data different from those which we used.

(4) A method is also presented for accumulating the favorability of numerous recognition criteria in a simple but systematic fashion so that the relative favorability for a deposit can be estimated.

(5) The methods presented for using recognition criteria suffer from several shortcomings including the non-independence of the recognition criteria themselves. While these problems detract from the mathematical and logical rigor of the method, we suspect that the errors introduced are well within errors associated with the collection and interpretation of the geologic data. Our attempt has been to present a system which is compatible with the quality of existing data but at the same time provides a useful mechanism for working with the large and complex volume of data and interpretations.

(6) By tying the recognition criteria as closely as possible to documented geologic observations, the results should be useful as a checklist for resource studies and exploration and as a basis for improving upon current concepts and methods. This first attempt undoubtedly has numerous 11mitations which, hopefully, will stimulate improvements by others.

\section{Reflections and Continuing Studies}

Throughout this compilation and interpretation of data for the South Texas deposits, we have been impressed with the paucity of data available for this important uranium region. We have, therefore, included suggestions for continuing studies that could improve exploration and resource studies.

\section{Potential for South Texas-type Deposits}

Uranium deposits will continue to be discovered in the South Texas Uranlum Region. The most promising areas are within mega-channel systems, particularly downdip from known deposits. Additional discoveries can also be expected within and as extensions of known mineral trends. It is possible that some of the older volcaniclastic-bearing Tertiary sediments may prove productive, and reported discoveries in the Carrizo Sand suggest this may be the case. The potential for the discovery of an entirely new district is considered to be only fair to good. 


\section{INTRODUCTION}

This report reviews the geology, genesis, and controls of uranium deposits in mixed fluvial-shallow marine sandstones, South Texas, for the purpose of describing those geologic recognition criteria which seem most useful for evaluating areas with potential for new deposits. The review on which the report is based is part of the National Uranium Resource Evaluation program of the United States Department of Energy (DOE).

The uranium deposits of South Texas occur in sediments deposited in complex fluvial-shallow marine depositional environments not represented in the other major uranium districts in the United States. The South Texas Uranium Region is the smallest of the four principal domestic uranium-producing regions. With estimated reserves of 49,000 tons $U_{3} \mathrm{O}_{8}$ producible at forward costs not exceeding $\$ 50$ per pound $\mathrm{U}_{3} \mathrm{O}_{B}$, the region contains about 5 percent of the domestic uranium reserves (DOE, 1979). Although these reserves are substantially less than those of the Grants Uranium Region, New Mexico (52 percent), the Wyoming Tertiary Basins ( 31 percent), and even the Colorado Plateau ( 9 percent), circumstances have combined to retard exploration and development in South Texas, and recent discoveries suggest that the Texas Coastal Plain may have more untested potential than some of the other regions. Current industry estimates (1980) for South Texas are about 88,000 tons $U_{3} O_{8}$, or approximately twice the DOE estimate. This reflects proprietary company information, particularly regarding new discoveries and recent additions to reserves.

Factors that have retarded mineral development in Texas include the nature of land ownership and the character of the deposits. The paucity of public lands has prevented the systematic exploration of large tracts, as has occurred in the western United States. Most of the area has been held by a patchwork of oil, gas, and other mineral leases, which were largely unexplored until the oil companies became interested in uranium exploration in the late 1960s. This fragmentation of ownership and lack of systematic regional exploration has retarded the development of uranium exploration and a1so inhibited the development, exchange, and release of information on the uranium deposits, perpetuating the paucity of data on the deposits and their geologic settings.

The uranium deposits in South Texas have tended to be smaller and lower grade than those in New Mexico and Wyoming. They are generally thin, seldom exceeding 15 feet, and rarely occur as stacked or multiple-front deposits, such as are common in some deposits in Wyoming and New Mexico. Although the size is in part an artifact of land ownership, the average deposit contains only about 10 million pounds $\mathrm{U}_{3} \mathrm{O}_{3}$, and the largest deposits known to date are estimated to contain about 30 miliion pounds $\mathrm{U}_{3} \mathrm{O}_{8}$. Compared to mines in New Mexico and Wyoming that contain three to five times these reserves, South Texas deposits would naturally be the last to be intensively explored by industry.

The unconsolidated nature of the host sandstone has prevented the development of underground mines, limiting exploitation to open-pit and in situ leaching operations. Since most new production centers will require recovery by in situ leaching operations, the lower grade, permeable ores of this region are a distinct advantage, and successful leaching systems are now routinely developed. 
Of particular importance in this report was the re-evaluation of the "South Texas Mineral Trend". This trend or belt (Plate I) has historically been drawn to include the known deposits, and the boundaries do not entirely correspond with regional geologic boundaries. The possibility exists, therefore, that the "trend" does not accurately reflect the area favorable for deposits. Although the trend does reflect important geologic features, such as the strike of the formations and positions of the favorable lithologic facies in some of the host sediments, there are geologic features that cross the trend, in particular persistent fluvial depositional zones, that are similarly important to the distribution of deposits. The deposits are likely to increasingly occur in clusters along the fluvial trends. These zones and new discoveries can be expected outside the trend, particularly toward the Gulf. To better reflect the shape of the mineralized area, we prefer, therefore, South Texas Uranium Region to former names.

In this report, we compile data on the characteristics of the sediments, hydrology, and uranium deposits of the South Texas Uranium Region. The environments of ore formation and the controls and genesis of the deposits are evaluated. A set of recognition criteria, based on observable geologic data, is developed for the types of deposit that occur in the region. Finally, the potential for discovering new deposits of this type either within the South Texas Uranium Region or within the United States is briefly evaluated in the light of the selected recognition criteria.

The project leading to this report was originally proposed in 1978 by Adams as part of a project to review the geology of the six major types of uranium deposits considered to have significant potential for discovery in the United States. The work plan provided for retaining six experienced geologists, each intimately familiar with one of the deposit types. The contract was awarded in November 1979, and the descriptive and interpretive material was prepared over the next several months by Smith. A system was then developed for estimating the favorability of areas for these types of deposits using selected geologic observations, referred to as recognition criteria. We then selected the recognition criteria on the basis of all accumulated geologic observations and the interpretations discussed in this report.

\section{Objectives}

The objective of this study is to contribute to the National Uranium Resource Evaluation (NURE) program of the U. S. Department of Energy (DOE) by providing a more comprehensive synthesis of the geology of the uranium deposits of the South Texas Uranium Region and a more systematic methodology for evaluating the favorability of geological information. The mission of the NURE program is to prepare more reliable and comprehensive uranium reserve and resource estimates for the United States. Preliminary reports have presented interim estimates of reserves in a series of cost categories and estimates of resources in probable, possible, and speculative categories. Estimates of reserves are based almost entirely on company data supplied to the Department of Energy. By comparison, estimates of undiscovered resources are based upon geologic judgement, which compares the geologic characteristics of known uranium districts with areas perceived to have uranium potential. An estimated resource potential is then assigned to the latter based upon the general geologic similarities, the comparative areas involved, and the grade and tonnage characteristics of the known district. 
The uncertainties associated with resource estimation are considerable, and generally accepted procedures for preparing such estimates have not been available. One major uncertainty is the selection, collection, and interpretation of geologic information. It seemed that the process of comparing geologic characteristics of known deposits with those of untested areas might be improved by identifying the most critical geologic observations (recognition criteria) and then estimating and accumulating the degree of geologic similarity. This possibility became an important part of the objectives of this study, which may be summarized as follows:

(1) Review the geology of the uranium deposits in the South Texas Uranium Region and identify the important geologic characteristics.

(2) Determine if significantly different types of deposits exist within this geologic setting and if new variants are likely to be discovered.

(3) Identify geologic characteristics which can be expressed as recognition criteria, the presence or absence of which most strongly affects the favorability or potential of an area for the occurrence of deposits such as occur in the South Texas Uranium Region.

(4) Develop a simple method for ranking the relative importance of the recognition criteria.

(5) Develop a method for accumulating the favorabilities derived from individual recognition criteria so as to estimate the favorability for these types of deposits in a reasonably systematic but practical fashion.

We have attempted to be thorough in our coverage of the South Texas Uranium Region and have included references to other districts and technical studies where they contributed descriptive material or information pertinent to ore controls and processes of ore formation. Our emphasis has been on the collection and review of well-documented data and observations so as to present a reliable data base for the interpretation of ore genesis and controls and the preparation of broadly useful recognition criteria. Attempts to develop more specific and refined criteria have not met with great success, due both to the range of conditions favorable for ore occurrence and the continued lack of much important geologic data for this region.

Source of Data

Data and observations in this report are based largely on published descriptions of the geology, hydrology, and uranium occurrences in the region. Whereas many of the previous studies have focused on particular deposits or formations, we attempt to discuss available data from the point of view of the lithologic, hydrologic, and geochemical systems which controlled the formation and distribution of the uranium deposits. Some details of individual deposits were derived from public records in Texas state agency offices as well as from uranium companies which generously cooperated during the compilation of this report. Data relating to uranium occurrences in certain formations were gathered from several excellent reports prepared by federal and state agencles. Ground water information was derived from numerous publications of the 
Texas Department of Water Resources and its predecessor agencies. Petroleum data have been drawn mainly from published ofl and gas field data obtained from the Texas Railroad Commission.

Acknowledgements

The writers wish to acknowledge the contributions of several geologists in Industry, the United States Geological Survey, and the Texas Bureau of Economic Geology, whose concepts, data, and assistance have become an 1mportant part of this report. In addition, we are indebted to those individuals in agencies and companfes who made avallable previously unpublished information, which has significantly broadened the data base for this report.

We also express our thanks to those colleagues who reviewed the manuscript and offered numerous constructive criticisms and other forms of assistance, in particular, Merle Crew and Steve Leedom, U.S. Department of Energy; S. R. Austin and C. A. Jones, Bendix Field Englneering Corporation; M. B. Goldhaber, U. S. Geological Survey; W. E. Galloway, Texas Bureau of Economic Geology; and F. D. Busche, Shell Oil Company. Jo Ann Fankhauser skillfully prepared numerous drafts of the manuscript and performed innumerable other tasks essential to the completion of this contract. 
The South Texas Uranium Region occurs on the broad flat coastal plain that flanks the Gulf of Mexico (Fig. 1). The Coastal Plain is underlain by more than 50,000 feet of interbedded Tertiary marine and non-marine sediments (Waters et al, 1955), whose depositional histories reflect interrelations between migrating shorelines (Wilson, 1968), relative and eustatic changes of sea level (Vail et a1, 1977a, b), and structural deformation (Bruce, 1972). Associated with these sediments is a large reserve of economic minerals and energy resources, the formation and distribution of which reflect the same geologic relations. Noteworthy are the occurrences of oil and gas, lignite, geothermal resources, and uranium. As all these resources occur in the same broad complex of depositional systems, the following brief description of hydrocarbon resources, which have been more thoroughly explored, will provide an introduction to uranium environments.

The position of shorelines in South Texas fluctuated during the Tertiary in response to sea level changes (Fig. 2), with deposition gradually prograding into the subsiding gulf, particularly since oligocene. This pattern is reflected in the distribution of petroleum resources (Geomap, 1979) which show a succession of offlapping and onlapping oil and gas reservoirs that occur generally in younger host rocks toward the coast. The relative positions of sea level corresponding to Cenozoic stratigraphic units are shown in Figure 3. Associated with this sediment pile are contemporaneous growth faults that become younger toward the coast and with which are associated structurally controlled hydrocarbon accumulations (Bruce, 1972; Jones and Wallace, 1974). Fisher and McGowen (1967, p. 122) note the generalization that oil and gas occurrences in Gulf Coast regions are controlled regionally by depositional facies and locally by structures. Galloway (1977) has estimated that onethird of the South Texas Coastal Plain is underlain by closely spaced hydrocarbon reservoirs that are largely fault controlled. (See Plate V.)

Petroleum commonly occurs in Tertiary sediments of the Texas Gulf Coast in delta front, strandplain, barrier bar, and shelf deposits (e.g., Fisher and McGowen, 1967; Fisher, 1969; Fisher et a1, 1970; Guevara and Garcia, 1972). Lignite occurrences may be found in fluvial deposits in updip equivalents of the same units, notably in the Wilcox Group, the Queen City (E1 Pico Clay), the upper Yegua Formation, and the lower Jackson Group (Guevara and Garcia, 1972; Kaiser, 1974; Johnston, 1977; Kaiser et al, 1978). In describing these occurrences Kaiser et al (1978) note the "cyclic" nature of Eocene deposition as reflected in outcrop by alternating sequences of regressive, fluvialdeltaic units and transgressive marine units.

In addition to the vertical and lateral changes in depositional patterns that have controlled the occurrence and distribution of oil, gas, and lignite, the accumulation of a thick Tertiary sediment pile has produced widespread geopressurized zones that have potential for geothermal energy. These zones formed where deltas prograded into the ocean and sank along growth faults into underlying prodeltaic, low-density muds (Bruce, 1972; Dorfman and Kehle, 1974; Jones and Wallace, 1974). Continued loading of coarse and fine clastic deltaic sequences on the deep, high-pressured muds forced water out of the muds into the overlying sands. In the process, this water became pressurized as well as overheated, hence a geothermal resource. Since the occurrence of 


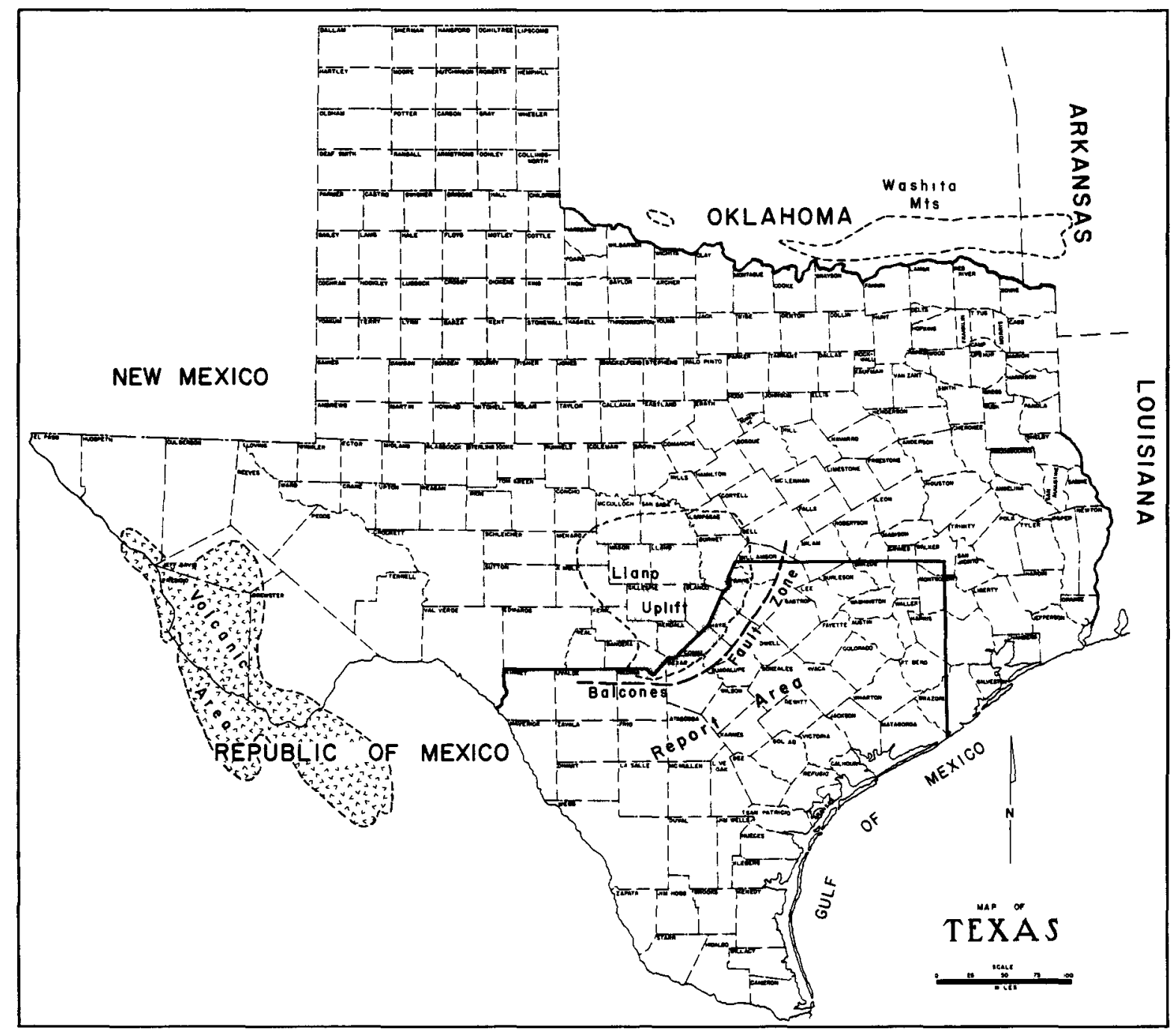

Figure 1. Location map for the South Texas Uranium Region and certain neighboring geologic provinces. 


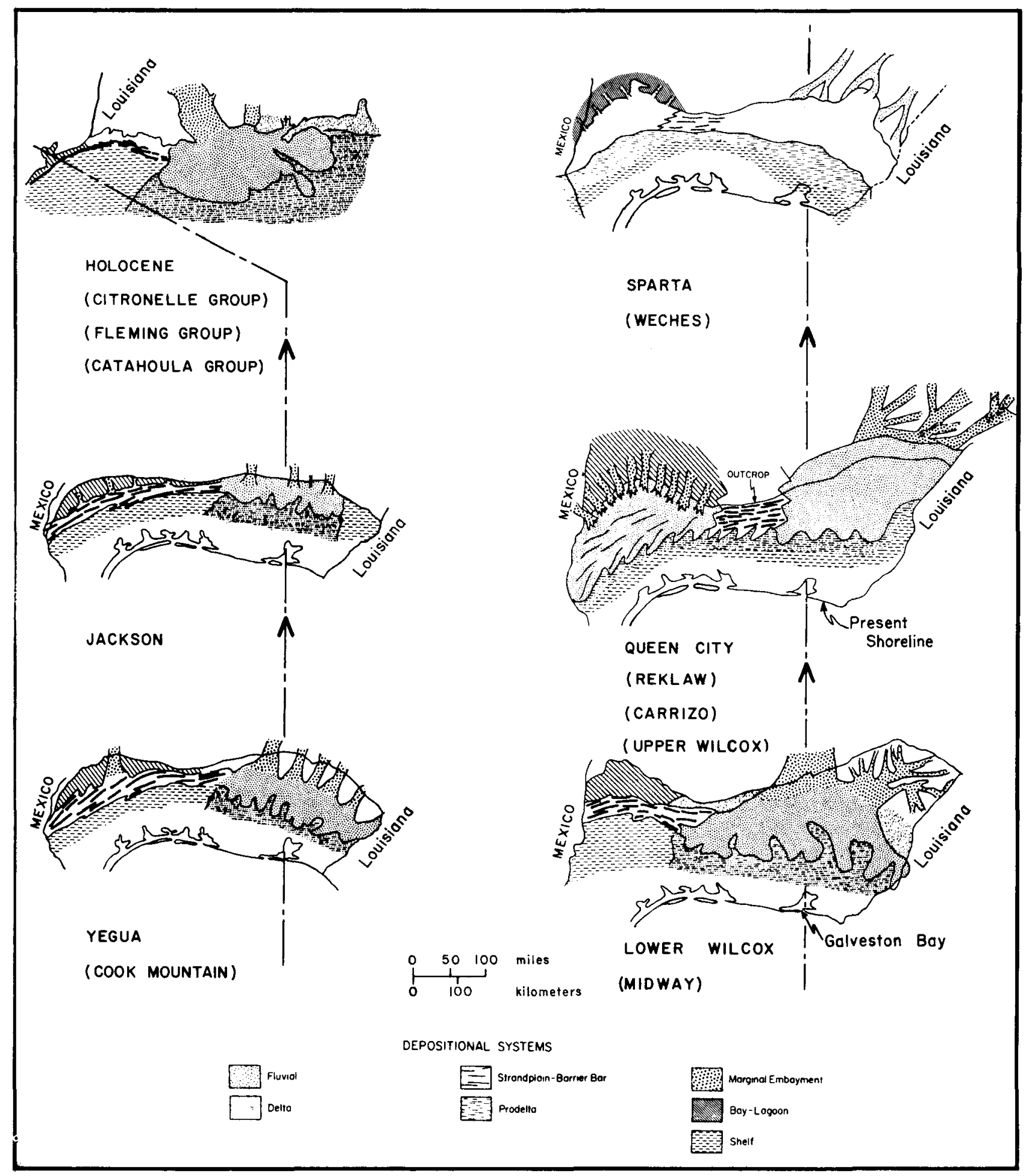

Figure 2. Distribution of depositional environments at six times during the Tertiary, South Texas (modified from Guevara and Garcia, 1972; and Ricoy and Brown, 1977). 


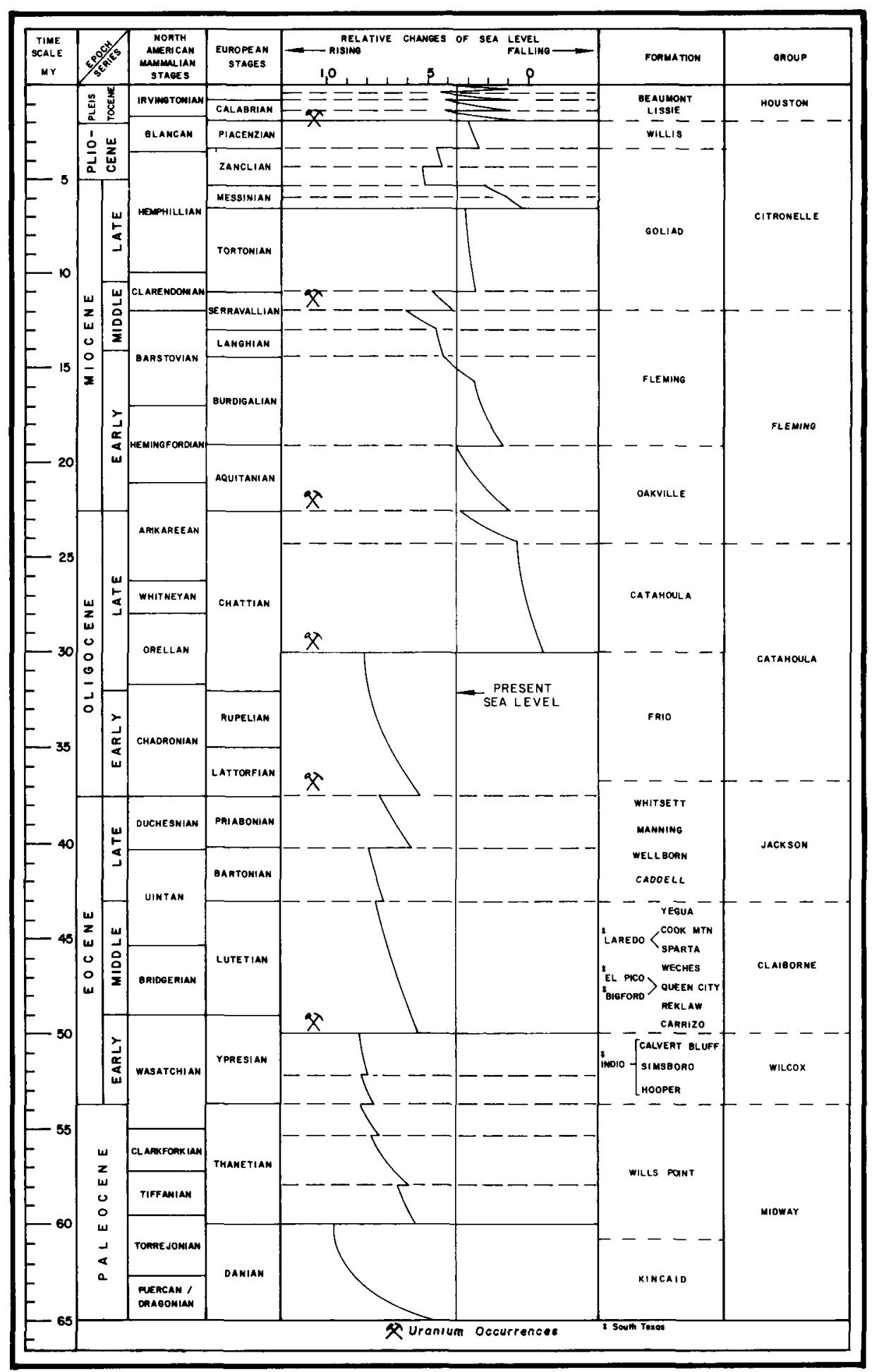

Figure 3. Cenozoic stratigraphy, global sea level changes, and princlpal uranium-bearing units, South Texas (modified from Berggren and Van Couvering, 1974; and Vail et al, 1977b). 
geopressurized zones is genetically related to progradational sequences, it is reasonable that geopressurized zones will also have a regional distribution corresponding to the distribution of deltaic units, growth faults, and even hydrocarbon occurrences. Since petroleum is commonly trapped along the same structures as the geothermal occurrences, both the petroleum accumulations and the geothermal zones are probably pressurized for the same reasons.

All of these energy resources of South Texas have, therefore, common features and are related to the fundamental depositional and structural history of the Texas Coastal Plain.

Only the fluvial systems within the time spans between the Jackson Group of Eocene age and the Goliad Formation of Miocene-Pliocene age are considered in this report. This is based on the presence of known uranium deposits within these formations which permits the development of a geologic base for the uranium deposits of the South Texas Uranium Region. By restricting our consideration to rocks of these ages, we do not intend to imply that older or younger formations are not prospective. In fact, we suspect that the opposite may be the case. Other formations meeting the characteristics of the known deposits are considered very prospective, but their study was beyond the scope of this report.

Due to the lack of information on the geologic characteristics and geologic setting of many of the uranium deposits in South Texas, a systematic discussion of all deposits in the region was not possible. As the best alternative, we have considered in as much detail as possible the deposits of the southern Duval County trend for which a reasonable amount of information is available, and we use this area as a model for the uranium occurrences in the rest of the region.

\section{Brief Geologic History}

During the Paleozoic and Mesozoic, periods of regional uplift and basin formation (Waters et al, 1955) accompanied major episodes of plate subduction and spreading (Keller and Cebul1, 1973), during which the basic structural features of the Texas Gulf Coastal Plain were created. This includes the major uplifted areas, arches, and embayments shown in Plate II, as well as the general homoclinal dip of the greater coastal area that is indicated by Plate III.

Widespread occurrences of evaporites in the Jurassic probably most represent the early period of basin formation in the Gulf of Mexico. The Lower Cretaceous is characterized by deposition of the Comanchean Series dominated by clastics and carbonates in the lower part and limestones in the upper part (Tucker, 1962). With the exception of a relative fall of sea level in Aptian time (Vail et al, 1977a) and deposition of the Edwards Formation (Rose, 1970, 1971), the Lower Cretaceous was primarily a period of advancing seas that covered the entire coastal plain area and extended to Central Texas. Following a relative fall and static sea level in Middle Cenomanian time and deposition of the Woodbine deltaic sandstones and shales (Va1l et al, 1977b), the Upper Cretaceous Gulf Series was deposited. This period was characterized by a gradual marine regression of the area of Central Texas and deposition of sandstones, shale, mar1, and chalk (Waters et a1, 1955) across the coastal plain. 
The end of the Cretaceous was marked by a sharp relative fall of sea level coinciding with major uplift of the Rocky Mountains. At the same time, major river systems were created that transported large volumes of clastic detritus from the Rockies, and to a lesser degree from the Appalachians, into the Gulf Coast. Ultimately this fluvial sedimentation led to the deposition of one of the largest accumulations of Cenozoic clastic sediments in the world (Matthews, 1974).

At the time major clastic deposition began in the Early Tertiary, the Texas coastline was at least as far as 125 to $150 \mathrm{miles}$ inland, which was somewhere north of the Paleocene Midway Group outcrop area (Wilson, 1968). The exact process of how the shoreline moved from its position in the Paleocene to its present location has been the subject of considerable speculation over the years. Most authors agree, however, that the Texas Coastal plain clastic sequence reflects "a complex interaction between sediment supply, sea level fluctuations, and regional subsidence in response to sedimentary loading" (Matthews, 1974). The major problem of interpretation of these sediments has been explaining not only the general "regression" of shorelines but also intervening marine units indicating "transgressions" as we 11 as an overa11 pattern of "oscillating" shorelines. Discussions of the subject invariably revolve around local interpretation of events involving either (a) the degree of sedimentation or subsidence (or "compaction") or (b) "depocenter migrations" as a means of explaining progradational episodes or the lateral or vertical migration of shorelines and depositional facies. Eustatic sea-level changes are generally added to explain anything that cannot be explained by subsidence and supply. The problems of Gulf Coast interpretation are difficult. However, where the same relative shoreline or depositional changes on a global scale can be seen, then the patterns along the Gulf Coast become easier to explain.

One model is provided by Vail et al (1977b), who write that global changes of sea level can come about by either geotectonic events, glacial changes, or other large-scale processes such as major periods of deposition following large-scale uplift. Throughout the Tertiary and Quaternary, there was a general relative fall of sea level superimposed on smaller oscillations of highs and lows (see Fig. 3 ). Sequences leading to highstands or relative increases of sea level ("transgressions") are conformable sequences, and those representing abrupt lowstands or a relative fall of sea levels ("regressions") produce unconformities (Vail et a1, 1977b). 
A general stratigraphic and sedimentologic framework is required for an understanding of uranium occurrences in the South Texas region. Figure 4 is a schematic stratigraphic cross section from the Rio Grande Embayment on the southwest to the Houston Embayment to the northeast. The area described in this report extends from the San Marcos Arch to the Rio Grande River (Plate I) and from the southern margin of the Central Texas Plateau, defined by the Midway Group outcrop (Plate III), to the Gulf Coast. This area is referred to as South Texas and includes the South Texas Uranium Region. In the following pages, the Tertiary stratigraphy of South Texas is described in some detail, as lithology is fundamental to an understanding of discovered deposits and the unexplored potential of the region. The Geologic Atlas sheets of Texas (published by the Texas Bureau of Economic Geology) have been important general references, together with other sources, for the descriptions of stratigraphy and lithologies which follow.

\section{Midway Group}

The oldest Tertiary rocks in South Texas form the Midway Group (Plate IV), dominantly a marine unit consisting generally of argillaceous and silty sediments that are commonly glaucontic in the lower portions. The contact of the Midway with the Cretaceous is either disconformable in the subsurface or is in fault contact along the Balcones Fault System (Plate II). The Midway is divided into two formations, the upper Wills Point Formation and the lower Kincaid Formation. In Plate III, the group is undivided except in southwest Texas where apparently only the lower portion of the unit, the Kincaid Formation, is exposed and hence denoted as such. The thickness of the Midway, where it is not overlapped by the Wilcox or faulted, ranges from 100 to 150 feet. In Dimmit and Zavala Counties, the Kincaid is up to 300 feet thick.

\section{Wilcox Group}

Overlying the Midway is the Wilcox Group, originally referred to as the "Lignitic Beds" (Safford, 1956; Fisher, 1961), which characterizes a major resource of the Wilcox. Because of its lignite content and its environment of deposition, Kaiser (1978) refers to the Wilcox as containing the best example of lignite-bearing cyclic fluvial-deltaic units in the Texas Eocene. The Wilcox marks a retreat from the marine conditions of the Midway as well as the first major cycle of fluvial conditions and delta formation in the Tertiary (Lowman, 1949). The lowest beds of the Wilcox also mark the beginning of the early Eocene, denoted by the appearance of the shallow-water oysters, Ostrea thirsae and 0. multilirata (Wilson, 1968).

The Wilcox Group is differentiated into formations beginning immediately east of the San Marcos Arch (Plate IV). From Bastrop County northeast to Van Zandt County, the Wilcox is divided into three conformable units. The Hooper Formation is the lowest and was deposited as a deltaic/fluvial-deltaic unit. 


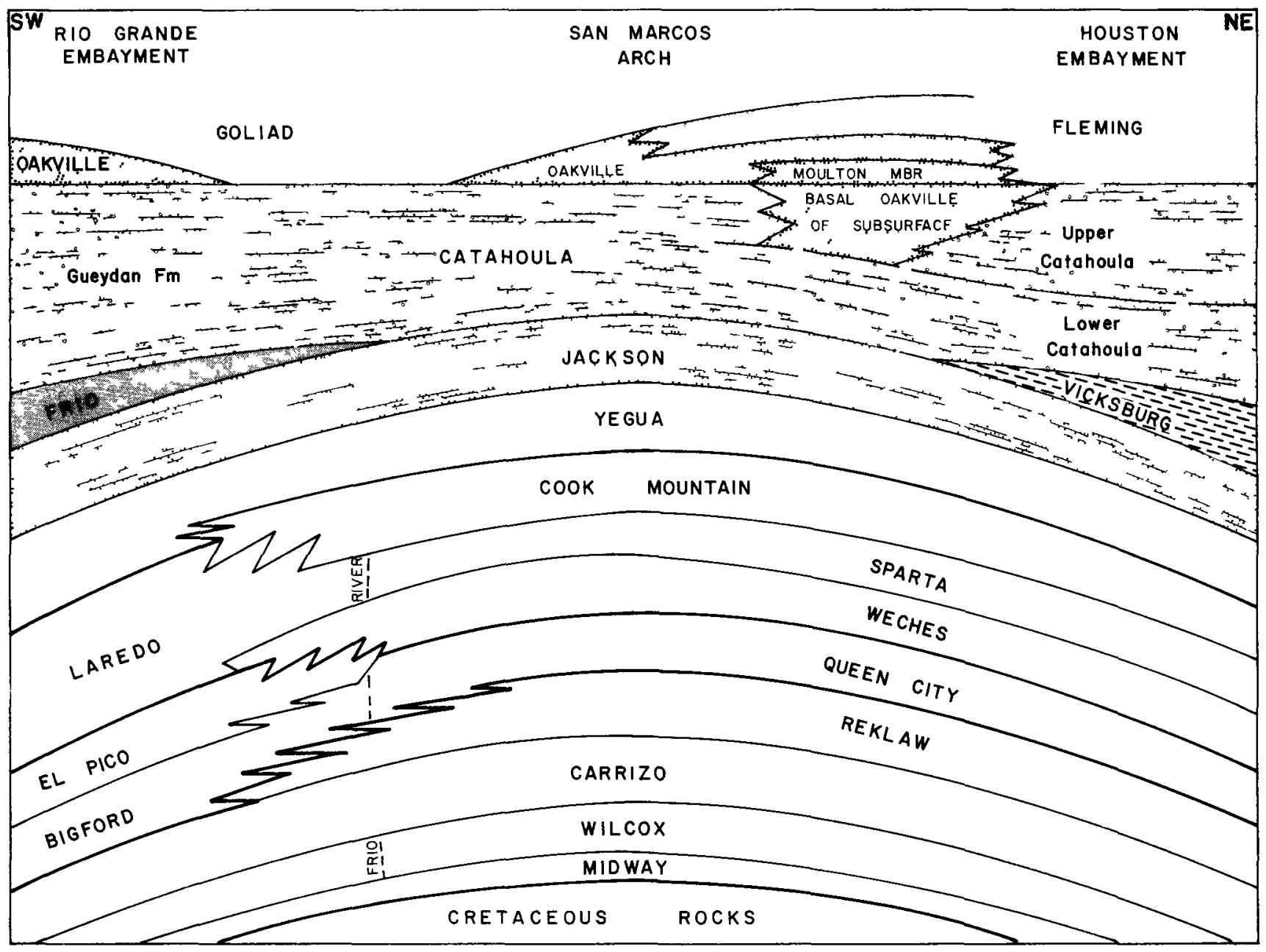

Figure 4. Diagramatic stratigraphic cross section from the Rio Grande Embayment to the Houston Embayment, South Texas (modified from Guevara and Garcia, 1972; Galloway, 1977; and Wilbert and Templain, 1978). 
It has an average thickness of 500 feet and consists primarily of glauconitic mudstone, clay composed mainly of calcium montmorillonite (Kohls, 1963), and some sand, sandstone, and minor 1ignite. The middle unit is the fluvial Simsboro Formation, which ranges from 75 to 300 feet and consists of classic highly meandering to braided, dip-oriented channel facies made up primarily of massive, heterogeneous, fine to coarse, cherty, feldspathic, and muscovitic sands and minor amounts of predominantly kaolinitic clay (McGowen and Garner, 1970; Koh1s, 1963). The upper unit is the fluvial-deltaic Calvert Bluff Formation, which ranges from 450 to 1,100 feet (Kaiser et a1, 1978; Barnes, 1974) and consists of predominantly montmorillonitic clays (Kohls, 1963). Lignite occurs in overbank facies as seams typically 5 to 10 feet thick but ranging from 2 to 25 feet in thickness (Lentz, 1975; Kaiser, 1974; Kaiser et al, 1978; Kohls, 1963) with thin beds of sand and sandstone.

Northeast of the San Marcos Arch, the Wilcox consists primarily of fluvialdeltaic sediments. Southwest of the arch, it consists of lagoons and barrier bars (Fisher and McGowen, 1967). Updip, the outcrop portion of the Wilcox in South Texas has been described and differentiated by Johnston (1977) into: (a) the lignitic "lower Wilcox", which is composed primarily of strikeoriented barrier-bar and strandplain systems, and subordinate dip-oriented delta and bay-lagoon systems; and (b) the largely non-lignitic "upper Wilcox", which is dominantly a deltaic depositional system. Johnston identified 12 deltaic lignite occurrences, 15 lagoonal lignite occurrences in the lower Wilcox in the subsurface, and 6 largely deltaic lignite occurrences in the upper Wilcox. In the subsurface and downdip, Jones et al (1974) describe a middle Wilcox marine shale unit that continues along strike but increases to a thickness of over 5,000 feet towards the coast. West of the Frio River in Frio County, the Wilcox is referred to in outcrop as the Indio Formation and consists of thin, fine-grained sandstone beds, sandy carbonaceous shale, and lignite, with numerous calcareous and ferruginous concretions. Fisher and McGowen (1967) also apply this name to describe the "Indio Bay-Lagoon System" in the updip portion of the Lower Wilcox. In outcrop, the Wilcox in South Texas ranges in thickness from 1,200 to 1,400 feet in an area immediately west of the San Marcos Arch to the Frio River, and 440 to 900 feet from west of the Frio River to where the "Indio Formation" reaches the Rio Grande.

\section{Claiborne Group}

Overlying the Wilcox Group is the Claiborne Group, a Middle Eocene sequence consisting of alternating and interfingering fluvial-deltalc and marine sediments that become increasingly marine coastward (Berg, 1970; Kaiser et al, 1978). Claiborne units were formally established by Dumble (1924), Wendlandt and Knebel (1929), Stenzel (1936), and more recently by Eargle (1968). This group consists of, in decreasing age, the Carrizo, Reklaw, Queen City, Weches, Sparta, Cook Mountain, and Yegua Formations.

\section{Carrizo Sand}

The lowest unit in the Claiborne is the Carrizo Sand, which is a major aquifer along much of the Gulf Coast (Payne, 1975). Early workers included the Carrizo, along with the overlying Reklaw Formation, in the now discarded "Mount Selman Formation" (Wendlandt and Knebe1, 1929; Sellards et a1, 1932). 
The Carrizo has traditionally been included in the Claiborne Group (Berg, 1970), although some workers argue for its being associated with the wilcox (Johnston, 1977).

East of the San Marcos Arch, the Carrizo has been extensively studied for its aquifer properties both in relation to ground-water production (Peckham, 1965) and as a means of mitigating ground-water contamination in the production of lignite from the underlying Wilcox (Henry, 1976; Kaiser, 1974). In the general area of the Brazos River Valley, the Carrizo in outcrop and updip areas is from 100 to 210 feet thick (Boenig, 1970; Barnes, 1974) and unconformably overlies the lignitic Calvert Bluff Formation. It is characterized by the abrupt appearance of fine to coarse quartz sand, calcareous sandstone boulders, and sandstone fragments; followed by well-sorted, massive, very porous quartz-rich, non-calcareous, ferruginous sand and sandstone with thin beds or partings of carbonaceous clay.

Payne (1975) describes the Carrizo in East Texas as a dip-oriented, fluvial valley and channel-fill sequence containing some bar and beach sands, all of which were deposited over an erosional surface that was sometimes deeply incised by post-Wilcox and pre-Carrizo rivers. Brewton (1970) conducted a detailed petrographic study of the Carrizo in East Texas and described some 22 heavy minerals including limonite, hematite, ilmenite, magnetite, and aluminosilicates and concluded the Carrizo River originated from the area of the Rocky Mountains, the Ouachita System, and even the southern Appalachians. Apparently the Carrizo consists of meanderbelt and braided-stream deposits as well as sands reflecting deposition along interdeltaic and deltaic areas on a low coastal plain bordering the Focene sea (Henry, 1976; Boenig, 1970; Brewton, 1970; Stephenson, 1953).

West of the San Marcos Arch and extending to the Rio Grande River, the Carrizo sands are up to 200 feet thick in outcrop and contain some shale interbeds with local occurrences of sideritic and limonitic concretions. Sands are fine to coarse grained and locally indurated with calcite or silica. Although no detailed petrographic study is available for the Carrizo sands in South Texas, it may well be that the Rockies and the Ouachita System further provided some of the same heavy minerals to this region as provided further east (Brewton, 1970). Payne (1975) concluded that the Carrizo in the subsurface in South Texas is never less than 50 percent and more commonly is over 80 percent sand.

The Carrizo-Wilcox unconformity apparently continues in the outcrop area and near surface throughout South Texas (Eargle, 1968), although it may well be that downdip in the subsurface the Carrizo becomes indistinguishable from the Wilcox (Johnston, 1977) as both units become increasingly marine and where interformational erosion was less important. Payne (1975) interprets the general strike-oriented nature of the subsurface sand bodies in South Texas as representing longshore and nearshore bars. It appears, however, that the more northerly updip portion of the Carrizo does represent major dip-oriented channels. In presenting this evidence, Johnston (1977) attributes the lack of lignite in the Carrizo to the absence of overbank facies, a general requirement for 1ignite in East Texas (Kaiser, 1974).

\section{$\underline{\text { Reklaw Formation }}$}

The Reklaw Formation disconformably overlies the Carrizo from just east of the San Marcos Arch to Frio County in South Texas where it pinches out. The 
Reklaw is characterized by glauconitic, fine to coarse sands, shales, and marly muds that represent a distinctly transgressive marine period relative to the Carrizo. In outcrop, the Reklaw consists of a lower unit, referred to as the Newby Member, which is made up primarlly of nearshore, ferruginous, glauconitic sandstones and sands with some gypsiferous clay, minor lenses or partings of 1ignite, and ironstone concretions (Stenze1, 1936; Sellards et al, 1932; Dunlap, 1955; Stephenson, 1953). Poorly preserved marine fossils have also been described from the Newby, the most common being the pelecypod Venericardia planicosta. Stephenson (1953) has described in some detail the occurrences of a conglomeratic facies up to 10 feet thick that sometimes occurs at the base of the Newby. This facies is composed largely of up to boulder-sized fragments of ferruginous or quartzitic sandstone and siderite concretions occurring in a matrix of quartz sands. He speculates that between the time of final deposition of the Carrizo and the first occurrence of Reklaw marine sediments, a period existed when relatively high-energy streams originating in nearby drainage basins eroded and reworked the underlying Carrizo and Wilcox units and deposited this facies on an outcrop.

Overlying the Newby with a gradational contact is the deeper water Marquez Shale Member, which consists of lignitic mudstone, carbonaceous or silty clay, gypsiferous or pyritic shale, and sandstone beds (Stenzel, 1936; Sellards et al, 1932). Foraminifera and Venericardia are also present.

In the subsurface, the Reklaw is described by Guevara and Garcia (1972) as locally containing glauconitic sands of the Newby shelf deposits, but it more commonly consists of glauconitic and fossiliferous marly muds and shale representative of prodeltalc facies.

Before pinching out in Frio County, the Reklaw is described as interfingering and grading upward into the deltaic facies of the Bigford Formation, which is the Southwest Texas equivalent of the lower Queen City Formation. Guevara and Garcia (1972) also describe sediment dispersal in the lower Newby shelf deposits as mainly strike oriented and consisting of reworking the underlying (Carrizo) deltaic facies by marine waves, tides, and longshore currents.

The thickness of the Reklaw ranges from 50 to 80 feet east of the San Marcos Arch to up to 200 feet in Southwest Texas.

\section{Queen City Formation}

According to Guevara and Garcia (1972), the Queen City Formation and equivalent stratigraphic units (the Bigford Formation and the E1 P1co Clay) (Plate IV) represent a predominantly sandy deltalc sequence sandwiched between the prodeltaic and shelf deposits of the underlying Reklaw Formation and the overlying Weches Formation. As summarized by Guevara and Garcia (1972), formational status was originally given to the Queen City by Kennedy (1892) for deposits in East Texas; Trowbridge (1923) incorporated the Queen City beds into the Mount Selman Formation in South Texas while naming the more fluvial sands and sparse lignites the Bigford Formation; finally, Eargle (1968) named the more lignitic beds of the Mount Selman Formation the E1 Pico Clay.

Queen City deposition began when deltas prograded over the glauconitic muds and fine clastics of the Reklaw prodeltaic sediments; thus, the Queen City represents a relative lowering of sea level. 
Major facies changes in the Queen City across the Texas Coastal Plain from northeast to southwest consist of constructive lobate deltalc facies in East Texas, strandplain deposits between the Colorado and San Antonio Rivers, and destructive deltaic deposits with associated fluvial meanderbelt (the Bigford Formation) and lagoonal (El Pico Clay) facies in South Texas. The strandplain facies correspond generally with the area of the San Marcos Arch. A point of interest is that Calendar (1957) contends the Queen City sands on the eastern flank of the arch, in Bastrop County, contain the same suite of metamorphic minerals as the Carrizo Sand (Brewton, 1970), suggesting a similar distant source area for both formations.

In South Texas, the principal facies and lithologies in the near-surface and outcrop appear to be: (1) dip-oriented meanderbelt sands and clays with belts up to 30 miles wide and 25 to at least 200 feet thick and associated interchannel clays, shales, and sume lignite, which occur primarily in the Bigford Formation; and (2) lagoonal clays, sometimes gypsiferous and argi1laceous, sometimes glauconitic sandstone, and impure lignites, primarily representing the $\mathrm{E} 1 \mathrm{Pico} C$ lay.

East of the Frio River, the Queen City Formation in outcrop ranges from 250 to 650 feet thick, while west of the Frio River, the Bigford Formation and E1 Pico Clay combined range from 900 to 1,800 feet thick.

\section{Weches Formation}

The Weches Formation represents a relative rise in sea level and is characterized as a fossiliferous and glauconitic unit representing shelf and prodeltaic deposition (Guevara and Garcia, 1972). The name Weches Formation was originally applied by Wendlandt and Knebel (1926) to the uppermost unit of the nowdiscarded Mount Selman Formation. Present usage maintains the formational status of the Weches across Texas extending to Frio County where the Weches in outcrop apparently merges with and becomes indistinguishable from the El Pico Clay (Eargle, 1968). Ricoy and Brown (1977), however, do differentiate the Weches from El Pico Clay in the subsurface.

Guevara and Garcia (1972) suggest that the transgressive marine facies of the Weches Formation, and hence the termination of predominantly deltaic deposition during the Queen City period, was due to either a shift in delta sedimentation centers, leaving a void that became filled by marine transgression, or tectonic movement that diverted the fluvial system that had fed the deltas. They also state that shelf sediments of the Weches are destructional facies of the Queen City deltas that probably came about due to decreasing cumpaction of the deltas that gave rise to a longer period of wave action. In either case, a relative rise in sea level occurred.

The Weches, east of the Frio River, ranges from about 30 to 50 feet thick and commonly consists of glauconitic, partly marly greensand and quartz sand, with glauconitic clay and silt interbeds. Invertebrate fossils are common, especially in East Texas, and reflect fafrly shallow, clear marine waters (Sellards et al, 1932).

\section{Sparta Formation}

Three principal depositional systems are described by Ricoy and Brown (1977) in the dominantly sandy Sparta Formation: a lobate constructive delta system 
in East Texas; a strandplain/barrier bar system that straddles the San Marcos Arch and extends southwest to McMullen and Atascosa Counties; and a destructive wave-dominated system that occupies the rest of South Texas.

The Sparta was originally the undifferentiated lower portion of the Cook Mountain Formation, as initially described by Dumble (1924). The Sparta was given formational ranking when its predominantly continental beds were distinguished from the more marine beds of what is now referred to as the Cook Mountain Formation (Wendlandt and Knebe1, 1926). West of the Frio River, the Sparta and the Cook Mountain together are referred to as the Laredo Formation on the basis of contrasting 1ithology changes (Gardner, 1938; Barnes, 1976). This distinction is based on the more argillaceous sediments in East Texas contrasting with thick sandstone sequences in the Rio Grande Embayment (Eargle, 1968). Recent studies of the Sparta by Ricoy (1976) have led to the differentiation of the Sparta throughout South Texas; however, details of this are not available at this time.

In East Texas, the constructive deltaic deposits of the Sparta consist of sandstones and mudstones in both the subsurface and outcrop, where exposures range in thickness from 150 to 200 feet. In the Central Texas area, strandplain and barrier bar deposits of the Sparta range in thickness from 130 to 150 feet thick and consist predominantly of a single strike-oriented, finegrained, quartz sandstone unit. In the Rio Grande Embayment, the Sparta and equivalent beds in the lower Laredo Formation consist of 150 to 250 feet of: (a) arcuate to cuspate, coarsening-upward sand bodies commonly 30 to 100 feet thick representing coastal barrier bar/strandplain facles; and (b) narrow, elongate lagoonal deposits composed of sands, silts, and clay, with some gypsum, Invertebrate fossils, and calcareous concretions.

Studies of the hydrogeology of the Sparta by Payne (1968) Indicated that in South Texas it has only local and relatively minor importance as an aquifer despite its high sand content. According to Ricoy and Brown (1977), fresh water is mainly found in the fluvial dip-oriented sand bodies of East Texas, whereas sulfate waters are commonly found in the strike-oriented sand bodies of South Texas that represent restricted paludal environments. They also note that, in general, transmissibility is greater in the East Texas dip-oriented sand bodies than in the strike-oriented sands of South Texas. This hydrologic style is important in subsequent discussions.

\section{Cook Mountain Formation}

Like the Weches Formation, the Cook Mountain can be described as a regionally persistent glauconitic, marly, and fossiliferous facles of marine shelf and prodelta origin (Ricoy and Brown, 1977). As mentioned above, the Cook Mountain was originally described by Dumble (1924), then differentiated into the lower Sparta Formation (Wendlandt and Knebe1, 1926), as well as into a now-discarded middle unit, the transitional Stone City Formation (Stenze1, 1936). The name Crockett Formation has since been abandoned in favor of the original name, the Cook Mountain Formation. As previously mentioned, in the Rio Grande Embayment the Cook Mountain is included with the Sparta Formation in the Laredo Formation (Gardner, 1938).

Throughout Texas, sediments of the lower Cook Mountain are described as highly fossiliferous, marly glauconttic mudstone of shelf origin whereas in the upper 
Cook Mountain, prodeltaic mudstone facies predominate (Ricoy and Brown, 1977). Along the western half of the Rio Grande Embayment, however, the lower Cook Mountain shelf facies merge with a clayey lagoonal facies, while the upper Cook Mountain prodelta beds merge with fine, sandy strandplain/barrier bar deposits. In the area of Webb and Zapata Counties, the latter appears to thin significantly in response to the overriding by the overlying Yegua delta system.

In the outcrop, the Cook Mountain ranges from about 200 to 350 feet thick, with thinning in the far west and major thickening downdip.

\section{Yegua Formation}

Unconformably overlying the Cook Mountain is the Yegua Formation, the uppermost unit of the Claiborne Group. The Yegua represents a major regressive episode and is characterized by: (1) very sandy constructive deltaic deposits in East Texas; and (2) sand, clay, and lignite deposits associated with widespread strandplain/barrier bar and small destructive deltaic facies in South Texas (Fisher, 1969).

Dumble's (1924) inclusion of the Yegua into the Claiborne in East Texas was extended to South Texas by Duessen (1924), who correctly considered the Yegua in outcrop to be mostly non-marine.

Fisher (1968, 1969) described the Yegua, primarily in the subsurface, and compared lithologies and facies in East Texas to those of the Lower Wilcox elongate constructive deltas. He also showed that the quartz sands in outcrop in East Texas are similar to the multilateral, highly meandering channel facies of the Simsboro Formation of the Rockdale Delta System. West of the Colorado River and extending to the Rio Grande, the Yegua consists of strikeoriented strandplain/barrier bar sands, represented by such subsurface sand units as the Pettus, Manita, Rosenberg, and the Bruni (Fisher, 1969) which are noted hydrocarbon sources. Fisher also described a small destructive delta system along the present-day Nueces and Frio River drainage. Associated fluvial fine quartz sands are dip oriented and can be observed in outcrop. These sands may be glaucontic or calcareous and may contain some chert. Elsewhere in outcrop are lagoonal lignites and clay that are derived from restricted environments in areas updip from the linear strandplain/barrier bar facies. Lignitic deposits are primarily known in LaSalle, McMullen, Starr, and Zapata Counties (Kaiser et al, 1978).

East of the San Marcos Arch, the Yegua in outcrop ranges from 750 to 1,000 feet. West of the arch, the Yegua reaches a maximum surface thickness of 1,050 feet in the central portion of the Rio Grande Embayment and then thins southward to 400 feet.

\section{Jackson Group}

The Jackson Group overlies the Yegua Formation and is mainly Upper Eocene in age. The Jackson is the oldest of the documented uranium deposit-bearing units in South Texas (Plate I). The Jackson is characterized in East Texas by 
dip-oriented constructive deltaic sands, muds, and lignites, and in South Texas by strike-oriented strandplain/barrier bar sand bodies and associated lagoonal muds and lignttes (Fisher et al, 1970). The latter also contain minor landward, dip-oriented channel sand bodies as shown on Plate VI and gulfward shelf muds that grade eastward across the San Marcos Arch into the prodeltaic muds of East Texas.

The general geology and nomenclature of the Jackson have been reviewed by Eargle and Snider (1957), Fisher et al (1970), Eargle (1972), Eargle and Weeks (1973), Eargle et al (1975), and Kaiser et al (1978). Because of the economic importance of the Jackson with respect to oil and gas, it has been subdivided in outcrop and near-surface into numerous formations, members, and informal units. Because of the rapidly changing nature of lateral facies in the Jackson, attempts to correlate individual units regionally have led to confusing nomenclature. Fisher et al (1970) have generally resolved these problems by combining surface and subsurface geology with detailed depositional analysis.

Four formations have been distinguished in the Jackson (Plate IV) covering three major "type" areas. The Manning and the Caddell Formations (also the now generally discarded McElroy Formation) were initially described in East Texas for sediments largely consisting of fosslliferous shelf muds flanking fluvial deltaic sediments. The Wellborn Formation was initially described in Central Texas (the San Marcos Arch region) for sediments consisting generally of delta-front sands, as well as locally occurring sand units, such as the Carlos Sandstone Member. The Whitsett Formation, described initially in South Texas, consists of several local strandplain/barrier bar sand units, such as the Dilworth, Deweesville (or the Stones Switch), and the Calliham (or the Tordilla) Sandstone Members and intervening lagoonal or shelf muds (which are locally pyritic) such as the Conquista, Dubose, and the Fashing Clay Members.

The lagoonal deposits already mentioned contain minor feeder channels leading to downdip associated strandplain/barrier bar deposits. These channels appear in outcrop in belts 5 to 10 miles in width with thicknesses averaging 40 feet. When such channels locally cut strike-oriented lagoonal sediments, such as the Dubose Clay Member, the unit becomes a dip-oriented sand body. Various other sand units have been named in South Texas in outcrop and the subsurface, but apparently these have not led to nomenclatural problems. It is important to note that volcanic ash and tuff, or bentonite, commonly occur throughout the Jackson and have long been a conjectured source for the uranium in South Texas uranium deposits (although evidence increasingly points to the overlying Catahoula Formation, e.g., Galloway, 1977; Galloway and Kaiser, 1979). In one such case in the Manning Formation, bentonite has been of sufficient quantity (up to $1.5 \mathrm{feet}$ ) to be referred to as a separate informal subunit called the Plum Bentonite.

The units described in the Jackson Group reflect lateral facies variation across the Texas Coastal Plain. In areas where the Jackson is thickest in outcrop, such as the Rio Grande Embayment, outcrop descriptions have produced the greatest number of sedimentary units. From the eastern flank of the San Marcos Arch to the axis of the Rio Grande Embayment, the total Jackson Group increases in relative thickness from 570 to 680 feet to 775 to 875 feet and progressively increases from four recognized units in the east to nine in the west. 
Frio Formation

The Frio Formation is commonly referred to in South Texas as the Frio Clay and is limited in outcrop (see plate III). The Frio Clay is up to 200 feet thick and is characterized as a thin mud interval that conformably overlies the Jackson and is unconformably overlain by the tuffaceous Catahoula Formation (Bailey, 1926; Sellards et al, 1932; Eargle, 1959; McBride et a1, 1968).

The Frio Clay was first described by Dumble (1894) and is often confused with the subsurface equivalent of the Catahoula Formation, the Frio Sand (see Galloway, 1977). Despite the importance of the Frio Clay to uranium exploration, it is one of the least described and least understood untts in the Texas Tertiary. The base of the Frio Clay in outcrop is marked by greenish-gray clays with thin sandy Jackson interbeds (Sellards et al, 1932). This gradational contact and the general conformity of the Frio Clay with the underlying sand/mud sequence of the Jackson are illustrated in the study of the Jackson by Fisher et al (1970). The main Frio Clay sequence consists of massive, dark greenish clay with a very minor amount of sand and sandy silt. The Frio also contains some gypsum and calcareous concretions. In Karnes County, the upper contact with the Catahoula Formation is marked by a sand layer, conglomerate, and coarse detritus (Sellards et al, 1932).

Sellards et al (1932) suggest the Frio Clay represents a continuation of Jackson conditions, at a time when adjacent land areas were nearly at sea leve1. They attribute the lack of clastics to low rainfall and river transport, and the absence of stratification and carbonaceous matter to a fresh water origin for at least part of the sequence.

The presence of gypsum in the unit, as well as the green clay, suggests restricted, probably brackish conditions such as a flat-lying coastal lake or a salt marsh. That the environment was lagoonal to marginal marine rather than deep marine is suggested by the presence of both oysters and foraminifera in some of the Frio Clay sediments (Sellards et al, 1932). The calcareous concretions found in the Frio clay could indicate efther lacustrine or lagoonal conditions. Analogies to a fresh water/lagoonal ecozone environment can be drawn from studies of coastal lake facles in the overlying Catahoula Formation (Galloway, 1977) and lagoonal facies in the underlying Jackson beds (Fisher et al, 1970). It is of interest to note that the lower Catahoula contains a thick sequence of coastal lake sediments immediately downslope from the Frio Clay outcrop (Galloway, 1977). This indicates that in both Frio and Catahoula times this "sand poor" zone represented a regional embayment removed from fluvial influences for some duration.

The age of the Frio clay is considered to be generally time-equivalent to the subsurface Vicksburg Group, which is Oligocene (Waters et al, 1955; Galloway, 1977; Baker, 1979). Sellards et al (1932) believe that the Frio Clay is older than the subsurface beds which they indicate to be predominantly Middle 0ligocene. Apparently, the Vicksburg is no younger than Middle oligocene (Stuckey, 1954). The Frio Clay probably represents the lower portion of the Frio Clay-Vicksburg Group interval. The gradational contact of the Frio with the underlying Eocene Jackson Group supports the age of the Frio as Early to Middle Oligocene age. There is evidence that the uppermost Jackson may be oligocene from the area just east of the Frio clay outcrop extending to East 
Texas (Wilson, 1968; Baker, 1979). If this is the case, then a Lower 0ligocene age for the Frio Clay-Jackson contact in South Texas is quite reasonable.

East of the point where the Frio Clay is overlapped by the Catahoula Formation in Live Oak County, the Frio Clay-Vicksburg is presumed to be in the shallow subsurface with the erosional edge probably only a few miles downdip from the edge of the Catahoula outcrop (Baker, 1979; also see Waters et a1, 1955; and Burke, 1958).

The subsurface Vicksburg Group, an important oil- and gas-bearing unit, is an extensive shale formation representative of a transgressive sea that apparently extended to just south of the Jackson outcrop area. In South Texas, especially in the area of the Rio Grande River, sand and clay interbeds indicate deposition in shallower seas as well as the influence of the paleo-Rio Grande River drainage (Burke, 1958).

\section{Catahoula Formation}

The Catahoula Formation is a highly tuffaceous fluvial unit that is Late oligocene in age and unconformably overlies the Frio Clay and the onlapped Jackson Group (see Plate III). The Catahoula also serves as a major host for uranium deposits in South Texas.

Current usage for the Catahoula Formation as employed by Galloway (1977) includes the Gueydan Formation of South Texas (McBride et al, 1968) and the Catahoula Formation of East Texas (Sellards et al, 1932). Subsurface equivalents currently referred to as the Catahoula Formation include the lower Frio Sand (also called the Frio Sandstone or the Frio Formation, e.g., Bebout et al, 1978), the overlying Anahuac Shale, and the basal portion of the Oakville Formation occurring uppermost in the subsurface section.

The marine shoreline during the Catahoula period was located about 25 to 50 miles inland from the present shoreline (Bebout et al, 1978). This represents a major regression relative to underlying units. Since the age of the Catahoula is generally considered to be Early or Middle Arikareean (McBride et al, 1968; Berggren and Van Couvering, 1974, p. 13-16), i.e., Late 01igocene, this regression probably corresponded to a worldwide lowering of sea level that took place 25 to 30 million years ago (Vail et al, 1977b). This age also corresponds to a radiometric date obtained for the Catahoula, which is $24 \mathrm{~m} . \mathrm{y}$. $\pm 1 \mathrm{~m} \cdot \mathrm{y}$. (McBride et al, 1968).

The Catahoula period was also characterized by major volcanic activity in West Texas, New Mexico, and the Sierra Madre Occidental range in northern Mexico, during which the Catahoula tuffs were erupted. Concurrent tectonic activity along the Balcones Fault System (Plate II) and erosion of the Cretaceous rocks of the Edwards Plateau by Catahoula rivers contributed reworked Late Cretaceous fossils in the Catahoula and younger units (Weeks, 1945; Young, 1962; McBride et al, 1968).

Depositional systems and sediment lithologies for the Catahoula in the nearsurface and outcrop area may be summarized from Galloway (1977). Although only 
briefly mentioned in this report, descriptions for deeper, time-stratigraphic Catahoula units, primarily occurring in the Frio Formation, have been summarized by Bebout et al (1975a, b, 1978) and Loucks et al (1977).

The Catahoula, like the older terrigenous sediments of the Texas Coastal Plain, consists of two distinct depositional systems occurring generally on either side of, or interfingering along, the San Marcos Arch. In East Texas, the Chita-Corrigan fluvial system occupies the Houston Embayment and consists of three principal mixed-load fluvial drainages, which lead to lobate constructional deltas in the deep subsurface. The Gueydan bed-load fluvial system occupies the Rio Grande Embayment and consists of one major drainage and several smaller fluvial channels, which lead to cuspate destructional deltaic and strandplain systems in the deep subsurface. Both systems are typified by channel-fill, crevasse splay, floodplain, and lacustrine facies.

Lithologies in both the Catahoula and the Frio Sand in East Texas and South Texas reflect their respective source areas and depositional environments.

Mineralogy of the Chita-Corrigan fluvial system in East Texas is characterized by a higher percentage of quartzose sands derived from great distance and a lower percentage of proximal-source volcanic rock fragments than the sands of the Gueydan fluvial system of South Texas. The latter reflects the nearby volcanic source areas to the west. The Gueydan sands contain up to 4 percent magnetite and ilmenite, whereas percentages for these minerals are minor in the Chita-Corrigan sands. Carbonate rock fragments are greater in South (and Centra1) Texas sands than East Texas. This probably reflects the closer proximity and greater exposure of the Edwards Plateau Cretaceous rocks to the Gueydan drainage.

The carbonate that does exist in East Texas is leached in outcrop. The clay minerals of the Catahoula contain a mixed calcium-sodium montmorillonite suite in South and Central Texas and a mixed montmorillonite-kaolinite suite in East Texas. Both montmorillonite and kaolinite are considered to be likely alteration products of volcanic ash. Since kaolinite formation is fostered by an acidic environment rich in humic acids, it is inferred that East Texas had a more humid environment with more widespread vegetation. Reprecipitated calcium carbonate derived from montmorillonite is common in paleosols in South Texas. This is reflective of dryer conditions and a sparser vegetation. Galloway (1977) points out that Gueydan paleosols commonly contain calcium carbonate concretion and cementation zones. He also notes that red, brown, or bleached oxidized soll zones are present, which characterized repeated wetting and drying conditions. The dryer climate is indicated by the preservation of chemically unstable carbonate rock fragments and plagioclase feldspars in the sands.

The considerable thickening of the Catahoula from East to South Texas reflects the Increased thicknesses in general in the Rio Grande Embayment, as well as the greater accumulation of Catahoula tuffs in South Texas due to the closer proximity to the western volcanic source area. Increased thicknesses from East to South Texas can be seen in cross section (Baker, 1979; Quick et a1, 1977) as well as in outcrop. The thickness of the Catahoula varies from 120 to 300 feet in the area of the San Marcos Arch in the Rio Grande Embayment to 800 to 875 feet in the southern portion of South Texas. 
The interest in the Catahoula in South Texas, for uranium as well as its greater thickness and surface exposure in the Rio Grande Embayment, has led to the differentiation of the Catahoula into more stratigraphic units. In the area of Karnes, Live Oak, and McMullen Counties, the Catahoula has been divided into three members: the basal Fant Tuff, the middle Soledad Conglomerate, and the upper Chusa Tuff (see Plate IV).

\section{Fleming Group}

The two Miocene formations overlying the Catahoula, the Oakville Formation and the Fleming Formation, may be reasonably included in the same group based on lithologic similarities and related depositional histories. As Galloway (1977) points out, the Oakville and Fleming together record a major depositional episode in the Miocene, and regional boundaries between the two are often gradational and arbitrary. Generally, the Fleming has a greater proportion of clay and the 0akville a greater proportion of coarse sandstone. The oakville is also a major host for uranium and an important aquifer.

In outcrop, in the area just east of the San Marcos Arch, the contact between the Oakville and the Fleming is gradational and arbitrary. Southwest of the arch, the two units are divided on the "Geologic Atlas of Texas" as far as Karnes County. Based on recent work by Galloway et al (1979a), the two units are tentatively divided on Plate III as far as southern Duval County, where both are onlapped by the Goliad Formation.

The Oakville and Fleming Formations are described in greater detall below.

\section{Oakville Formation}

The Oakville Formation unconformably overlies the Catahoula Formation (McBride et al, 1968; Sellards et al, 1932) and is early Miocene (Hemingfordian) in age (Wilson, personal communication, 1980). In outcrop, the Oakville is a coarse clastic fluvial unit that resulted from a major episode of tectonically induced rapid sedimentation along the Coastal Plain. The Oakville is characterized by reworked volcanic debris, as well as chert, and Cretaceous rocks and fossils derived from the Edwards Plateau. The deposition of the latter resulted from increased tectonic activity and erosion along the Balcones Fault System (Weeks, 1945). A decrease in the amount of reworked Cretaceous material from Central to East and South Texas reflects the influence of the faulting and the proximity of depositional source areas (Ragsdale, 1960).

The Oakville Formation was originally named by Dumble (1894) for deposits near the town of Oakville in Live Oak County. Usage of the term Oakville Formation (also known as the Oakville Sandstone) is limited to that interval between the top of the Catahoula and the top of the upper member of the Oakville, the Moulton Sandstone (Wilson, 1956), which is a calclithic, fluvial sandstone unit occurring in Central Texas (Renick, 1926; Ragsdale, 1960). The Moulton is underlain by the Lower Oakville Member, which consists of light-green and blue calcareous clay deposited in a swampy environment (Wilson, 1968).

As summarized by Galloway et a1 (1979a), the Oakville in South Texas consists of bed-load and mixed-load channel fills and associated sheetflow splay sands 
that are bounded by floodplain muds and silts in the Lower Oakville Member and the overlying Fleming Formation. The Oakville was deposited by several contemporaneous small to large rivers (Plate VIII) that form the Oakville bedload fluvial system. In the area mapped as the Fleming Formation, the Oakville is bounded by relatively fine-grained, ferruginous, high-energy, mixed-load fluvial beds. Downdip, the Oakville grades into equivalent subsurface units consisting of low Coastal Plain and strandplain facies of deltaic and barrier bar systems. Wilson (1968) notes that the position of the Oakville shifted in the (early) Miocene and that its average position would be approximately beneath the present shoreline. Quick et al (1977) note the presence of strandplain barrier bar deposits found near the surface adjacent to the present-day coastline in Calhoun County.

Galloway et al (1979a) note that paleosols occur latera1ly in the Oakville, but that they are poorly defined. They describe the most abundant clay mineral in the Oakville as montmorillonite with variable amounts of kaolinite and subordinate illite. Massive, calcareous floodplain mud deposits also occur containing concentrations of pedogenic micrite nodules, which attests to a syndepositional carbonate precipitation phase. The latter is of ten obscured by post-depositional calichification from the Reynosa Caliche (see Price, 1933) that occurs prominently in outcrop.

The Oakville ranges in outcrop from up to 200 feet just east of the San Marcos Arch to up to 500 feet in the area of Karnes County.

\section{Fleming Formation}

The Fleming Formation generally has a higher clay content than the Oakville and is representative of floodplain or paludal depositional conditions. The Fleming is conformable with the Oakville Formation and like the Oakville is considered Miocene in age. Based on studies of vertebrate faunas in the Fleming, its age is considered to be Barstovian (Wilson, personal communication, 1980), Upper-Lower to Middle Miocene (see Berggren and Van Couvering, 1974).

As discussed by Wilson (1956), usage of the name Fleming Formation now incorporates beds previously referred to as the Lagarto Formation in Southwest Texas. Plummer (1932) has described the Lagarto as consisting of 75 percent clay, and the remainder sand and silt, although apparently in some areas the ratio of sand to clay approximates that of the Oakville (Baker, 1979). More commonly, sand beds are thinner and less massive than those of the Oakville (Sellards et al, 1932). Cretaceous calclithic fragments and fossils may be found occurring in the sands of the Fleming. Ragsdale (1960) has found that the distribution of this Cretaceous material along strike is simflar to that of the Oakville. Thus, the calclithic fraction is highest in Central Texas and proportionally decreases to the northeast and southwest. This signifies the influence and proximity of faulting along the Balcones Fault System.

Fleming 1ithology is described as remarkably unfform in outcrop from the northeast to the southwest. Sellards et al (1932) attribute this to deposition by low-energy streams on a low coastal plain. They suggest that deposition occurred at a time when rivers were nearer to base level and were carrying finer sediments derived from source areas of higher vegetation and less torrential rainfall. They describe the mud as calcareous and, like the 
Cretaceous fossils, derived from the Edwards Plateau. Lagarto streams were continually changing courses, working their way back and forth across the Coastal Plain, and covering it with a thick mantle of fine-grained deposits.

As discussed by Sellards et al (1932), the Lagarto/Fleming shoreline was not far from the present Beaumont-Lissie contact. They note that ofl wells on the Beaumont plain penetrate brackish water and marine beds below the base of the Lissie. The position of this shoreline would be inland about 25 miles from that of the 0akville and would represent a relative rise in sea level that corresponds to a similar rise in sea level occurring worldwide in the Lower Miocene (Vail, 1977b) (Fig. 2).

It is apparent that the Fleming period was accompanied by generally wetter, more humid, and warmer conditions. This is typified by uniform, massive and thick mud deposits that were derived from areas of high vegetation and were deposited on a coastal plain that was probably water saturated. That these conditions remained generally constant for a long period is indicated by the thickness of the Fleming, which in much of South Texas is the thickest of all the Tertiary units. From west of the San Marcos Arch to just east of its onlap by the Goliad Formation, the Fleming ranges from 1,200 to 1,450 feet thick.

\section{Citrone1le Group}

The name Citronelle was originally used by Matson in 1916 as a formational name for Pliocene sands overlying equivalent beds of the Fleming Formation in Louisiana, Alabama, and Mississippi (Sellards et a1, 1932). The name was then extended to include simflar sands in East Texas. Following the differentiation of these sands, Sellards et al (1932) then used Citronelle as a group name to include a lower unit of Pliocene sands occurring in South Texas, the Goliad Formation, and an upper unit of sands occurring in East Texas, which at the time was unnamed but was considered Pliocene in age. This upper unit is now referred to as the Willis Formation; however, subsequent workers considered the Willis to be Pleistocene and placed it in a separate group. Based on new age estimates for the Goliad, however, the Willis may still be part of the Citronelle Group. Since no fossils have been found in the Willis, however, its exact age is unknown.

\section{Goliad Formation}

The Goliad Formation unconformably overlies the Fleming Formation and has traditionally been considered Pllocene in age, although recent studies now give the Goliad an Upper Miocene to Early Pliocene age. The Gollad is typically a coarse, clastic fluvial unit that was deposited by a series of moderately low-gradient, intermittently torrential streams that crossed a broad, flat coastal plain. The Goliad is also a major aquifer and a host for several known major uranium orebodies.

Accepted usage of the Goliad, as adapted by Sellards et al (1932), includes three members: the lower Lapara Sands, consisting of a conglomerate composed largely of quartz and chert cobbles, cross-bedded coarse sand, and limy clay; an unconformable middle unit, the Lagarto Creek Beds (distinct from the 
Lagarto Formation), a pinkish-brown to reddish mottled limy clay; and the upper La Bahia Beds, composed of fine to coarse, cross-bedded or massive sandstone with conglomerate lintels containing quartz, chert, and jasper aggregates.

Based on studies of vertebrate fossils recovered from the Goliad, the currently accepted age of the Lapara Sand is Clarendonian, which is upper Middle to Late Miocene, and the age of the La Bahia Beds is Hemphillian, which is predominant1y Late Miocene (Patton, 1966; Tedford et al, 1973). Cretaceous fossils also occur in the Goliad, as in underlying units, which again reflects the influence of the Edwards Plateau as a source area.

It is probable that final deposition of the Fleming Formation coincided with the onset of a prominent regression and cooling period that occurred at the end of the Barstovian and at the beginning of the clarendonian in the upper Middle Miocene (Vail, 1977b; Berggren and Van Couvering, 1974) (Fig. 2). This may be reflected in South Texas by the unconformity occurring between the Fleming and the Goliad Formations. This is marked by the appearance of coarse, clastic, fluvial sands and conglomerates of the Lapara Sand overlying the mud and silts of the Fleming. With the exception of minor intermediate rises in sea level, which may be represented in part by the Lagarto Creek Clay Beds, this regression continued unabated throughout the remainder of the Miocene. The clastic La Bahia Beds may well represent this final Miocene regressive phase.

Late Miocene terrigenous sediments bearing contemporaneous vertebrate faunas within equivalent units of the Citronelle Group are well documented elsewhere along the southern U. S. Coastal Plain (Alt, 1968). These clastic sediments, like those of the Goliad, commonly form a thick mantle covering subjacent Miocene marine sediments that may be equivalent to those of the Fleming Formation in South Texas. It is apparent that this late Miocene regressive period coincided with widespread aridity marked by lowering temperatures over the southern U. S. and elsewhere (A1t, 1968; Bandy, 1968). This was conspicuously the case in South Texas and is apparent by the Reynosa Caliche that formed syngenetically with or immediately following late Goliad sedimentation (Price, 1933). Caliche is in sufficient quantity to reach thicknesses of up to 20 feet and is an important road and building material for South Texas. It is of interest that significant caliche deposits occur throughout the central Rio Grande Embayment impregnating older Tertiary units (Garner et a1, 1979). Though caliche or its derivatives undoubtedly formed in South Texas during different arid periods and are still forming today, some of the caliche deposits occurring updip from the Goliad may have their origin during late Goliad times. If such is the case, then these caliche outliers would delimit the Goliad paleotopography and relate to Goliad paleodrainage patterns.

It is apparent that Goliad drainage consisted of a series of streams crossing the coastal plain in a southeastward direction (Plate IX). The source of the Goliad quartz, chert, feldspar, and calcium carbonate would have been the rocks of the Edwards Plateau and the Llano Uplift in Central Texas, as well as the Diablo Plateau in West Texas. It is known that by the end of Miocene time, the crystalline core of the Llano Uplift had been exposed and partly denuded. The Mesozoic rocks of the surrounding Edwards Plateau were continuing to be eroded as they had been since Catahoula times. Volcanic constituents contained in the Goliad were likely derived from the still-active volcanic fields in West Texas and northern Mexico. Along the coastal plain, salt domes such as Palangana, 
Piedras Pintas, and Alta Verde were emerging during which localized areas of pre-Goliad sediments were uplifted, eroded, and redeposited by Goliad streams.

Gollad streams were wide and had a low gradient in the coastal plain area and increasingly higher gradients updip towards Central and West Texas. Although brief wet periods apparently existed during Goliad time, conditions were generally arid. Discharge of Goliad streams was probably subject to periods of torrential rainfall, during which rivers greatly increased in both velocity and size. Principal drainages in South Texas were the ancestral Rio Grande (Belcher, 1975), the Nueces, Atascosa, San Antonio, and Colorado Rivers. Since the Goliad overlaps older Tertiary units extending to the Jackson (Plate III), it is apparent that hundreds of feet of Miocene and oligocene sediments were scoured by Goliad streams. This no doubt contributed to the massive multi-storied buildup of Goliad sands downdip that reach thicknesses of up to 450 feet (Quick et al, 1977).

The Goliad shoreline was confined to the immediate present-day coastal area as is evidenced by strandplain and barrier bar deposits that occur beneath the eastern portion of the Beaumont Formation (Quick et al, 1977). This represents a marked retreat in the position of shoreline from the Fleming period.

\section{Willis Formation}

The Willis Formation does not outcrop in South Texas and can only be seen overlying the Goliad in the area of the San Marcos Arch, where it ranges in thickness from a few feet to approximately 30 feet (Plates III and IV). The Willis unconformably onlaps the Fleming Formation in East Texas and may reach a thickness of 100 feet or more. The Willis is characterized as a fluvial unit composed predominantly of up to cobble-size quartz and chert gravels, as well as abundant iron oxide concretions and cement.

Sellards et al (1932) referred to the Willis as the unnamed "upper sands of the Citronelle Group" that in some places have the appearance of ancient upland terrace gravels and sand. In this regard, the willis has been correlated with the calcified Uvalde Gravel (Plate IV), which is found updip in South Texas and occurs as a sheet or plateau gravel on stream divides. The most prominent outcrops of the Uvalde Grave1 are 20 to 30 feet thick, occur on the southern margin of the Edwards Plateau, and may correlate with similar terrace gravels occurring on the margin of the plateau in Central and East Texas.

The Willis Formation has long been viewed as the eastward extension of the Goliad because both units occur between the Fleming and the Lissie Formations. A number of workers have recognized that the Willis is younger than the Goliad (Quinn, 1955; Bernard and LeBlanc, 1965). The most compelling reason for this is its overlap with the Goliad along the San Marcos Arch. Also, it has long been recognized that the Willis is lithologically distinct from the overlying Lissie Formation. Apparently, the similarities of the Willis to the Goliad, and the fact that the Willis can be seen in the field dipping beneath the Lissie, are the reasons that led Sellards et al (1932) to include the Willis Sands in the Citronelle Group. A number of subsequent authors also included 
the Wills in the Citronelle Group and considered its age to be Pliocene (Doering, 1956) as was originally believed by Sellards. Conversely, various workers have considered the Willis to represent the base of the Pleistocene and have correlated the Willis with the Williana Formation in Louisiana, which is considered basal Pleistocene (Frazler, 1974; Bernard and LeBlanc, 1965). Unfortunately, no fossils have been recovered from the Willis so its age must be estimated on other grounds, however tenuous. The view presented here is that if the Willis is more lithologically similar to the Gollad which is predominant1y Upper Miocene, and since the Lissie has an Identifiable Pleistocene fauna, then a Pliocene age for the Willis, as originally suggested by Sellards et al (1932), is quite reasonable.

It appears that the Willis Formation, the Uvalde Grave1, and other associated upland terraces represent typical sequences of intermittent, high-energy fluvial and sheetflood deposition occurring under arid conditions. It could be that this deposition occurred during even more arid conditions in South Texas, namely during the continued formation of the Reynosa Caliche (Price, 1933), which appears to have continued to form following the main period of Goliad deposition. It has been well established, by analogy with conditions today (McGowen et al, 1977), that for much of the Tertiary, conditions were generally dryer and warmer in South Texas than East Texas. Contrasting climatic conditions could explain the absence of the Goliad in outcrop in East Texas. The development of high-energy Willis streams accompanied by the higher precipitation east of the San Marcos Arch would serve to scour out underlying deposits. This is evident by the erosional unconformity at the base of the Willis and the top of the Fleming. Likewise, Increased aridity and extensive calichification in South Texas have no doubt enhanced the preservation of the widespread Goliad deposits.

The upper Goliad member, the La Bahla Beds, is considered Hemphillian in age which is Late Mlocene to Early Pliocene. On the basis of various criteria, it is reasoned that the Goliad as a whole was deposited generally during a regressive and 1ncreasingly arid period that coincided with a drop in temperature across the Northern Hemisphere. Bandy (1968) and Alt (1968) suggest this temperature drop colncided with an expansion of ice masses in the Late Miocene similar to that during the Pleistocene, though not of the same magnitude. Price (1933) also suggested that the formation of the Reynosa Caliche signified the beginning of a glacial perlod, although he was referring to Pleistocene glaciation. Based on what is now known of the age of the Gollad, it is suggested that the main period of calichification may have colncided with the deposition of the Willis, which is speculated to have occurred in the P1iocene. In this context, the Middle Pliocene was also a period of lowering temperatures, aridity, and increased glaciation in the Northern Hemisphere (A1t, 1968; Bandy, 1968). If the age of the Willis is indeed Pliocene, then its occurrence may correspond to this Middle Pliocene dry period.

Both the Early and the Late Pliocene recorded marine transgressions worldwide, presumably in response to a eustatic rise in sea level during "interglactal" periods (Alt, 1968; Bandy, 1968). The early Pliocene transgression was the more prominent and prolonged (Fig. 2) and is recorded in the southeastern U. S. In tectonically stable areas by emergent shorelines 90 to 100 feet above present sea level. Considering the subsidence that has occurred in the Rio Grande Embayment throughout the Tertiary, an Early Pliocene shoreline would be 
expressed well into the subsurface. Any equivalent landward sediments that may have existed would likely have been obliterated by Willis and later Lissie streams that flowed in the Pleistocene. Likewise, Lissie streams would have likely removed any post-Willis Upper P1iocene sediments that may have existed. Apparently, the Upper Pliocene represented fairly equitable climatic conditions elsewhere in Texas, as is noted by a diverse mammalian fossil fauna occurring in the Panhandle in beds that represent the type locality for the Upper Pliocene Blancan period.

\section{Houston Group}

The end of the Pliocene and the beginning of the Pleistocene record rapidly cooling temperatures in the United States assoclated with the first Pleistocene glacial period. This is recorded in the Texas Coastal Plain by an e rosional unconformity at the base of the Lissie Formation that marks the base of the Pleistocene. The association of this unconformity with the "first" glacial period has been a subject of considerable debate, as indicated by the previous discussion on "glacial" periods in the Late Miocene and Middle Pliocene. Because of this debate, the unconformities at the base of the Goliad and at the base of the Willis have been variously described as the base of the Pleistocene (Bernard and LeBlanc, 1965; Frazler, 1974). Unt11 a date is in some way derived from the Willis, no doubt the debate will continue. What is generally agreed upon is that the Lissie and the overlying Beaumont Formation have a diagnostic Plelstocene fauna and can be traced from South Texas to East Texas and Loulsiana where they merge with the Bentley, Montgomery, and Prairie Formations (Sellards et al, 1932; Bernard and LeBlanc, 1965; Garner, 1967) (Plates III and IV).

The name Houston was first applied by Sellards et al (1932) to the group of units occurring between the top of the citronelle Group (the Willis and Gollad Formations) and the base of the overlying Recent coastal silts and windblown sands. Apparently Fisk (1944) was the first to relate Pleistocene terraces on the Gulf Coastal Plain with time-equivalent subsurface units. He showed that each Pleistocene depositional surface is underlain by a distinct stratigraphic unit grading often from basal gravels and sands upward into progressively finer sediments (Bernard and LeBlanc, 1965). Frazier (1974) described this in terms of individual, genetically related stratigraphic units that are separated by major hiatal surfaces that distinguish glacial low-sea level periods from interglacial high-sea level periods.

The Lissie Formation in South Texas has known urantum anomalies and is considered a host for uranium (Geodata International, Inc., 1979; Union Carbide Corp., 1979). In outcrop, the Lower Lissie (the Bentley Formation) can be easily distinguished from the calichified upper surface of the Goliad. Also, a thin gravel commonly occurs at the base of the Lissie. In the subsurface, an angular disconformity exists between the Lissie and the Goliad.

The overall Lissie Formation is up to 200 feet thick and consists of meanderbelt, levee, crevasse splay, and distributary sands overlain by floodplain mud. The top of the Upper Lissie (Montgomery Formation) commonly contains iron oxide, iron manganese, and calcareous concretions and is impregnated and 
capped by caliche deposits in a similar manner as the Gollad Formation (Price, 1933). The overlying Beaumont Formation (the Prairie Formation) has no known uranium anomalies and is characterized as mostly clay and silt with lesser amounts of channel and barrier island sands and gravels.

The position of the shoreline during the Pleistocene ranged from several hundred feet below present sea level during glacial periods to 40 to 45 feet above present sea level during interglacial periods (Fig. 1) (Alt, 1968; Imbrie and Imbrie, 1979). Any existing high stands of the Lissie period are coverad by the Beaumont Formation. Shoreline deposits of the latter exist in outcrop; but, given the history of subsidence in the Rio Grande Embayment, they should be closer to present sea level than their original position. 
The preceding discussion of the stratigraphy and lithologies of the South Texas Uranium Region has emphasized the effects of global sea level changes, depositional environments, and paleoclimate on the formation of the sediments of the region. This background provides a framework for introducing the diverse occurrences of uranium in the Texas Coastal Plain (Fig. 3 and Plate I).

Uranium occurrences have been found at specific intervals throughout twothirds of the Cenozoic stratigraphic column. These occurrences represent a time span of at least 8 to 12 million years and involve, in particular, the following uranium-bearing untts (from oldest to youngest): Carrizo Sand, Whitsett Formation, Catahoula Formation, Oakville Formation (Moulton Sandstone), Lower Gollad Formation (Lapara Sand), and possibly the Lissie Formation. In all cases uranium occurs within regressive units that unconformably overlie transgressive sequences. The latter are represented by the Upper Wilcox Group, Manning Formation, Frio Clay, Lower Oakville Formation, the Fleming Formation, and possibly the Lagarto Creek Member of the Goliad. Insufficient information is available for the Lissie, but presumably any significant uranium occurrences within this unit would be above (or below) the first Lissie interglacial deposits.

The uranium deposits are related to unconformities as they commonly occur within the lower portions of generally porous, regressive units and above impermeable transgressive units that serve as aquitards. It seems to make little difference whether the sands of the regressive units are strandplain/ barrier bar, deltaic, or fluvial deposits. The fluvial deposits, however, commonly have higher porosity, transmissivity, and a steeper hydrologic gradient, all of which favor the introduction of oxidizing waters and their transmission to the various sources of reductants avallable to the megachannel systems. The bounding aquitards similarly may reflect different depositional environments and occur as marine shelf clays, restricted marine muds, or coastal lacustrine deposits. In addition to the effects of sea level and climatic changes on the deposition and modification of the sediments, the constant loading of sediments into the Gulf Coast Basin produced instabilities that led to local faulting and further geologic complexities. The extent to which basement structure controlled these features 1 s unclear, but the structures in turn affected subsequent sedimentation. Plate II shows the location of the principal faults and fault systems in South Texas which form a general arcuate pattern around the basin of sedimentation. Figure 5 is a schematic illustration of the development of a series of growth faults. In many cases, displacements on the growth faults placed sands and shales in juxtaposition and formed ideal traps for hydrocarbon accumulations.

Figure 6 is a schematic cross section of an oil and gas deposit controlled by a growth fault. Numerous such hydrocarbon accumulations are known in South Texas as reference to Plate II (faults) and Plate V (oil and gas deposits) illustrates. Also shown in Figure 6 are the paths that $\mathrm{H}_{2} \mathrm{~S}$-bearing gasses 


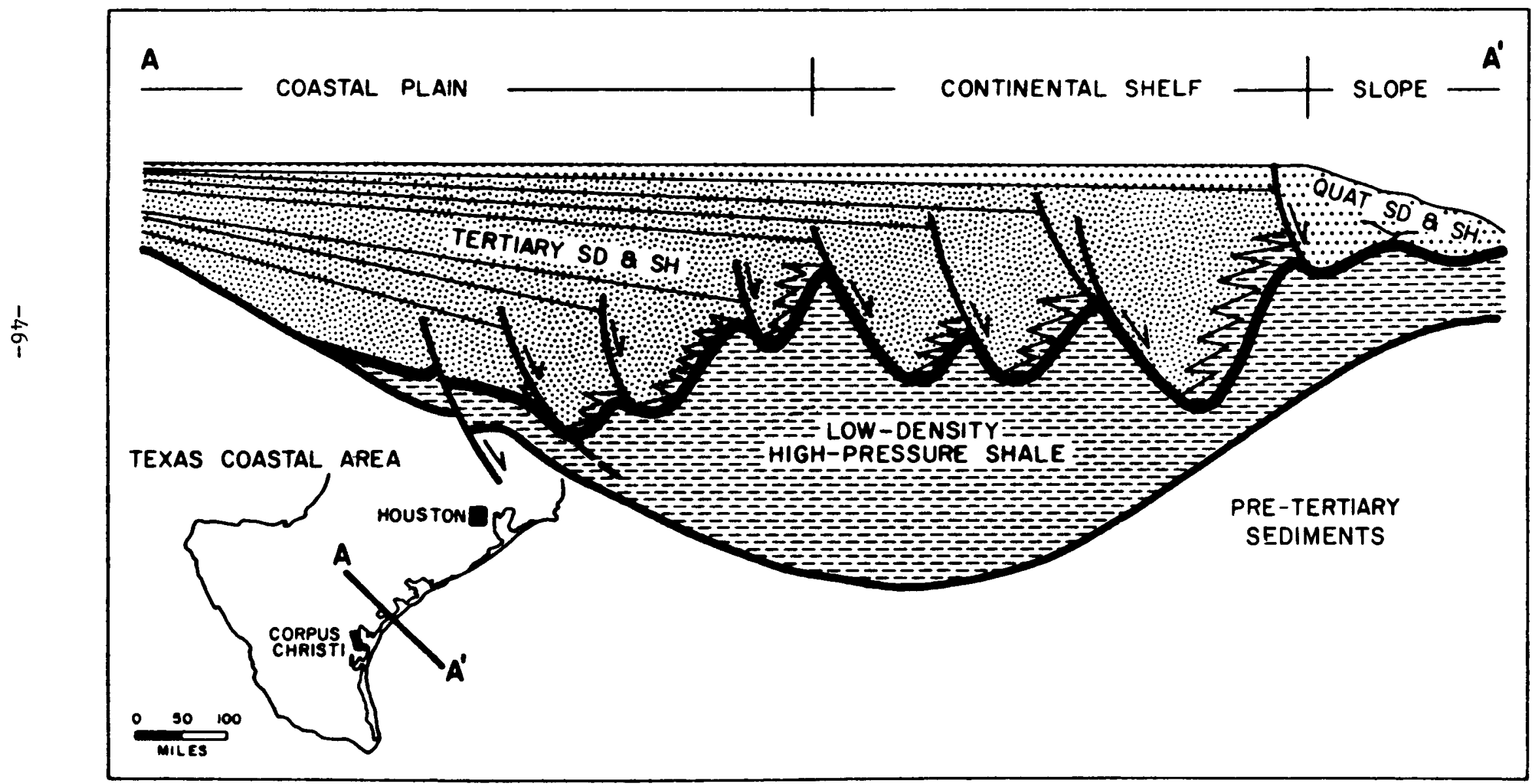

Figure 5. Schematic cross section depicting the development of growth faults, South Texas (modified from Bruce, 1972). 




Figure 6. Schematic cross section depicting the accumulation of hydrocarbons and movement of $\mathrm{H}_{2} \mathrm{~S}$ associated with growth faults, South Texas. 
might have followed when allowed to seep from the reservoirs along the growth fault. These gasses are believed to have been important to the formation of certain types of uranium deposits in South Texas as will be discussed in a subsequent section. However, current studies suggest, on the basis of sulfur isotopes, that only the deep Mesozoic reservoirs could have provided the heavy sulfur found in pyrites associated with several deposits. In addition, the growth faults, and their disruption of the stratigraphy, influenced the hydrology of the sediment piles which, in turn, influenced the formation of uranium deposits.

Hydrologically, any of the thick sand sequences deposited within major fluvial channels probably were aquifers for migrating ground waters from the time of deposition. The uppermost, near-surface sections would have transported fresh ground water, but as the aquifers became buried deeper beneath younger sediments they would have become more saline. Growth faulting and inter-communicating sand bodies probably allowed the fresh ground water system to maintain a near-constant depth below the surface. Galloway (1977) and Galloway et al $(1979 \mathrm{~b})$ describe how ground waters can cross aquitards and continue their downdip migration in a younger aquifer. Figure 7 is a diagrammatic sketch showing fresh ground water surmounting the aquitards and being deflected into younger aquifers adjacent to the same growth faults that control hydrocarbon accumulation and $\mathrm{H}_{2} \mathrm{~S}$ migration. $\mathrm{H}_{2} \mathrm{~S}$ may also form in settings other than hydrocarbon accumulations, and species transported in solution probably include HS.

The continuation of these related geologic events throughout Tertiary time developed the conditions essential to the formation of some of the important uranium orebodies in South Texas. Figure 8 is a sequential illustration showing the development of the geologic conditions leading to the formation of uranium mineralization associated with introduced reductants. This style of mineralization apparently applies to all deposits except those that occur in the Jackson Group and possibly the Carrizo Sand and those associated with salt domes.

The host rocks and uranium deposits in the South Texas Uranium Province have been described by numerous authors including Eargle and Weeks (1973); Eargle et al (1975); Galloway et al (1979a); and others. Numerous additional publications have dealt with particular deposits or formations, and some will be briefly discussed below.

There is consensus that most uranium deposits in South Texas bear great resemblance to the deposits of the Wyoming basins but with some marked dissimilarities. The occurrence of deposits in both regions as roll fronts at the boundaries between oxidized and reduced sediments is the most important similarity. The important dissimilarities reflect the numerous depositional environments of the host sediments and their complex interrelations in South Texas. Although these depositional environments have modern analogs that have been studied in some detail, for example the Texas Coastal Plain, short-range variations within the sediments render them more difficult to study than the host sediments in the Wyoming basins. The distribution and characteristics of roll fronts are strongly affected by relations between transmissive sediments and indigenous and extrinsic reductants, factors that are particularly difficult to predict in the subsurface in mixed fluvial-shallow marine sedimentary sequences. The proximity and migration of shore face, beach, 


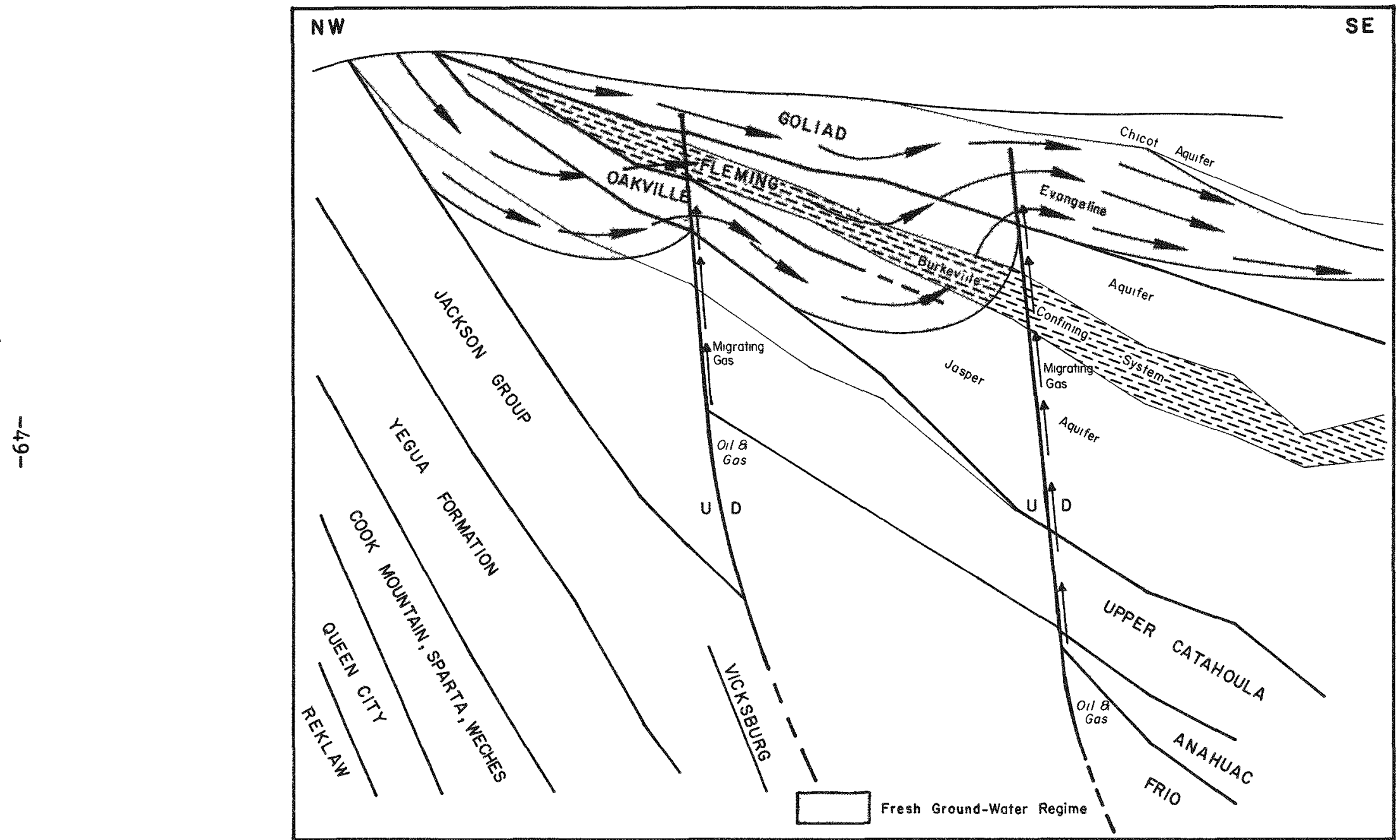

Figure 7. Diagrammatic cross section showing the migration paths of fresh ground water and fault-related $\mathrm{H}_{2} \mathrm{~S}$, South Texas (modified from Baker, 1979). 


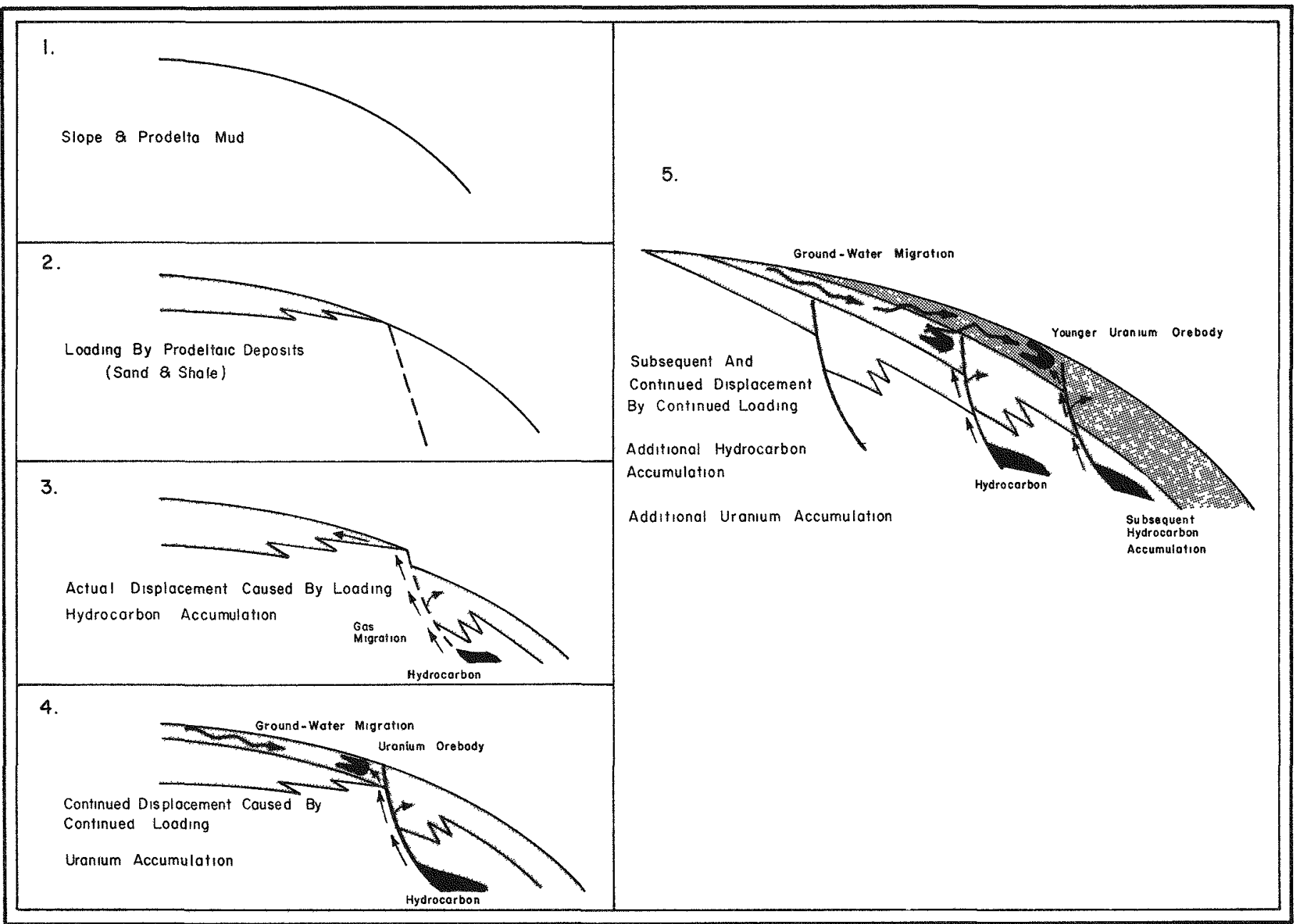

Figure 8. Schematic cross sections showing the sequence of events leading to the formation of uranium deposits related to fault-derived $\mathrm{H}_{2} \mathrm{~S}$, South Texas. $\mathrm{H}_{2} \mathrm{~S}$ introduction 1ikely preceded and followed roll-front formation but was not synchronous. 
lagoon and bay, paludal, and fluvial sedimentary environments account for the rapid lateral and vertical changes in 11 thology and the apparent complexities in the characteristics and distributions of the uranium deposits. Uranium deposits in South Texas occur in four principal geologic settings: (1) in sandstones above salt domes, (2) in beach sandstones and related sediments, (3) along the margins of major fluvial channel systems, and (4) in sandstones close to faults along which hydrogen sulfide has been introduced into the aquifer. These deposit types are not always mutually exclusive and may overlap or be superimposed upon one another. Each ore environment reflects the sediments and hydrology and the depositional environments that produced them.

Many of the uranium deposits of South Texas have the classic characteristics of the roll-type deposits of the Wyoming basins. They (1) occur at the margins of tongues of altered sandstone and (2) display the characteristic uranium disequilibrium patterns, elemental zoning, and mineral distributions which indicate that the alteration and formation of the deposits were the result of oxidizing solutions moving through the sandstone. The general features of roll-type deposits have been discussed in a companion report (Harshman and Adams, 1981) and will not be reviewed in detail here.

Other deposits in South Texas do not resemble rol1-type deposits. The uranium mineralization is not at the margin of a tongue of altered sandstone but is completely within reduced sulfide-bearing, hematite- and limonite-free sandstone (hematite may be found in polished sections). It has been proposed that these deposits were originally formed by the same processes which form roll fronts, but the host sands were subsequently flooded with $\mathrm{H}_{2} \mathrm{~S}$ leading to the re-reduction of part of the altered sandstone tongue. These deposits are, therefore, only a varlant of the roll-type deposit which owe their formation to the introduction of reductants, some of which are believed to have been derived from hydrocarbon sources deeper in the sediment pile. Some investigators do not yet accept the re-reduction mechanism (S. R. Austin, personal communication, 1980).

The characteristics of some of the deposits in South Texas are briefly described below. These descriptions will then be compared with classical roll-type districts in an effort to summarize the genesis and controls of the South Texas deposits.

Deposits in the Jackson Group

More than thirty open-pit mines and extensive exploration have produced considerable information on the deposits in the Jackson Group. The general and detailed characteristics of the uranium mineralization have been described by numerous authors, including Fisher et al (1970); Bunker and MacKallor (1973); Eargle and Weeks (1973); Eargle et al (1975); Dickinson (1976a, 1976b); and Galloway et al (1979a). Brief reference to the general features of these deposits, which are shown on Plate VI, and more detalled discussion of a few deposits w11l serve to characterlze uranium mineralization of the Jackson Group.

The only exposures of the deposits are in open p1ts which Galloway et a1 (1979a) describe as generally occurring in the Tordilla sandstone and the 
Deweesville (Stones Switch) sandstone of the upper part of the Jackson Group. These sands are interpreted to be a complex of depositional types that were deposited as part of a strand line, broken locally by small bay deltas. Figure 9 is a schematic representation of relations between uranium deposits in the Tordilla Sandstone Member in western Karnes County and the interpreted depositional environments. The deposits are associated with the coarsest sandstone units, which are interpreted to have provided the greatest permeability during ore formation and include coastal-barrier, inlet, cuspate-delta and distributary-channel-fill facies. The orientation of the host rock and contained roll systems is parallel, therefore, to the paleo-coastline. The shapes and orientations of the roll fronts are irregular and variable depending upon the geometry of the host sandstone. This indicates the strong control of depositional environments on ore distribution. Fine-grained lagoonal sediments are unproductive except locally where their basal lignites immediately overlie mineralized sands. In these cases, the lignites may contain economic uranium concentrations along the contact. Other 1ignites, such as the older Manning, usually show anomalously low radioactivity on gamma-ray logs.

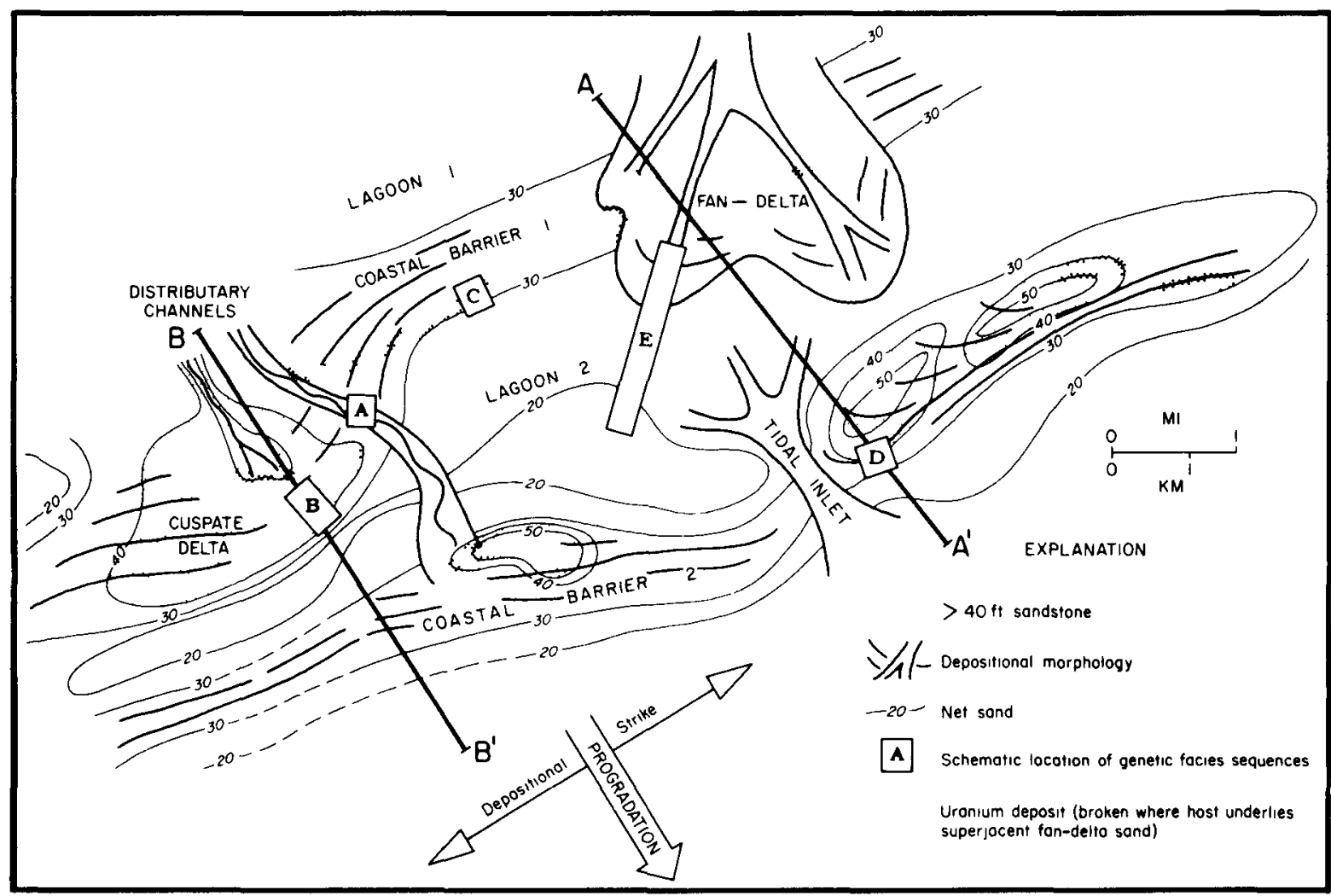

Figure 9. Uranium deposits and net-sand isolith for Tordilla Sandstone Member of Upper Jackson Group, Western Karnes County, South Texas. Depositional environments identified include distributary channel (A), cuspate delta (B), coastal barrier-bar (C), tidal inlet (D), and lagoon (E) (modified from Galloway et al, 1979a). 
A series of small oxidized deposits in the Deweesville Sandstone Member of the Whitsett Formation occur along a trend approximately $10 \mathrm{miles}$ in length in Karnes and Live Oak Counties (Fig. 10). According to Eargle et al (1975), the stratigraphic setting of these deposits is similar to other Jackson deposits. They have yielded about 200,000 tons of ore averaging about 0.2 percent $\mathrm{U}_{3} \mathrm{O}_{8}$, and disequilibrium in favor of radiometric uranium is common. Unoxidized deposits in Karnes County occur along a parallel belt to the southeast and are also shown in Figure 10. These deposits are generally larger but of lower grade than the oxidized deposits and, as one would expect, disequilibrium is less common. The main ore trend is a single roll front that extends for approximately 6 miles. The broader roll system, which may be composed of one or more rolls, extends for several additional miles to the northeast and southwest. In cross section, the rolls commonly display the characteristic crescent shape, convex in the downdip direction. On the updip, concave side of the rolls, the sands are oxidized and otherwise altered and range in color from pale gray to buff. The unoxidized sands of the downdip side are medium gray in color. The thickness and grade of the ore diminish gradually from the roll front to an assay cutoff several hundred feet downdip. The mineralogy of the ore, according to Eargle et al (1975), has not been investigated in detail, but both uraninite and coffinite have been identified. Reynolds and Goldhaber (in press) have studied the Panna Maria deposit and report organic matter and associated pyrite that occurs commonly as framboids and replacements of plant fragments. In addition to the customary detrital minerals, clinoptilolite, authigenic feldspar, opal, and montmorillonite are also present.

Deposits vary from as little as 2 feet to 25 feet in thickness in host sands that are from 20 to 30 feet thick. Widths may vary from 50 feet to 300 feet. Lengths of the Jackson orebodies are often considerable and can extend for a mile or more. Ore grades vary from 0.04 percent to over 2 percent $\mathrm{U}_{3} \mathrm{O}_{8}$, and most ores have averaged between 0.1 and 0.2 percent $\mathrm{U}_{3} \mathrm{O}_{8}$.

Several roll fronts in Jackson deposits exposed in open pit mines show a northerly direction of migration rather than a southeasterly, downdip migration direction. If this phenomenon is widespread, then the residual Jackson channel sands in southeastern LaSalle County and in east-central Webb County could also be prospective where they may have been in hydrologic continuity with the Catahoula Formation.

The source for the uranlum in the Jackson deposits is considered by most investigators to have been in the tuffaceous sediments of the overlying Catahoula Formation. However, the Jackson sediments contain their own volcaniclastic material which some investigations suggest might have provided the source for the uranium. Galloway et al (1979a) consider the volcanic material within the Jackson an improbable source, because early mobilization would have occurred in a zone of regional ground-water discharge. They argue that the dissolved uranium would have migrated into surface drainage and on into the Gulf. The optimum recharge for the Jackson in the vicinity of Karnes County would have occurred, in their opinion, later where the Upper Jackson sands subcropped directly beneath the basal Catahoula tuffs, which they consider the source for the uranium. 


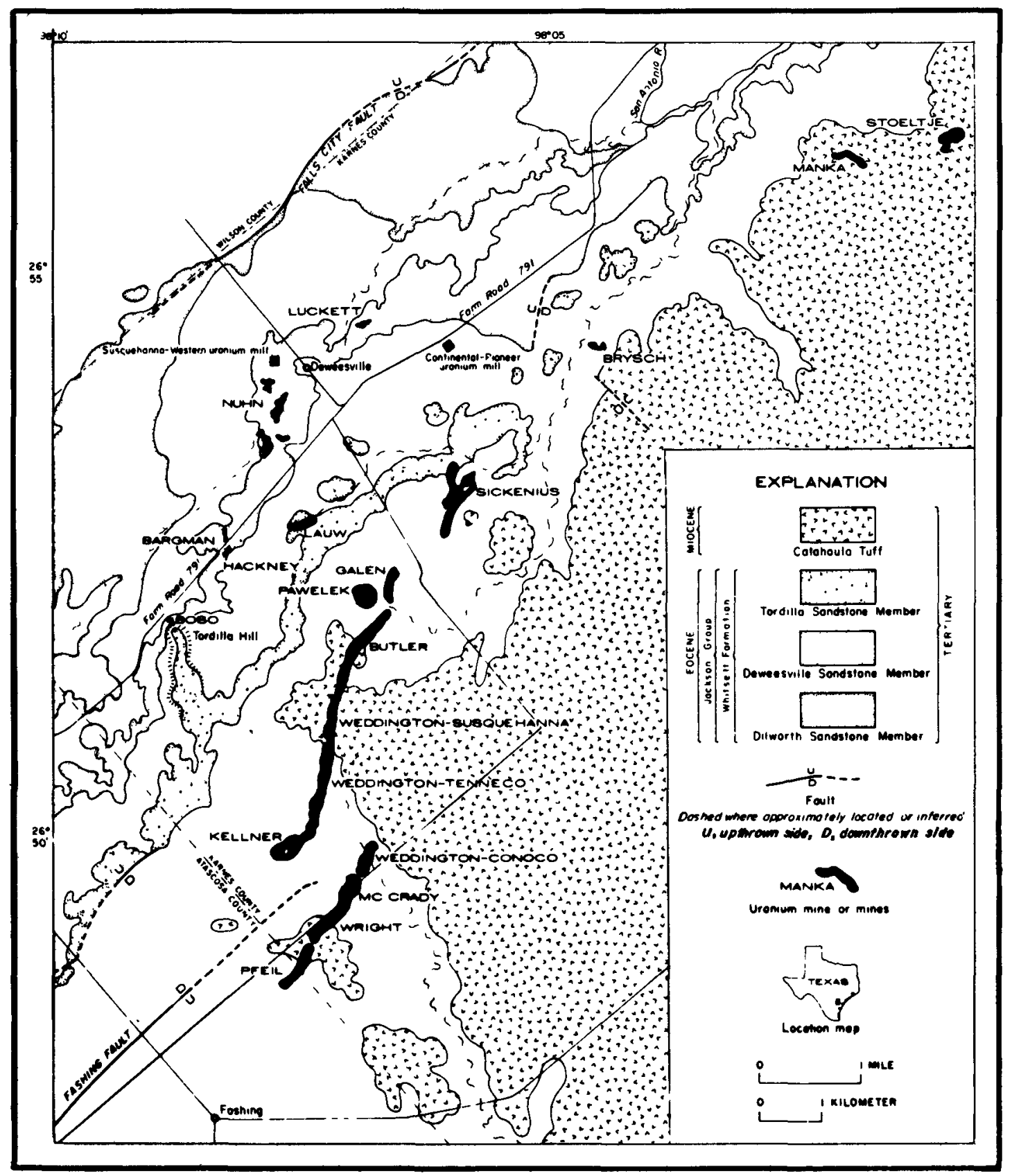

Figure 10. Geologic map showing parts of Karnes County and locations of uranium mines (from Eargle et al, 1975). 


\section{Brysch Uranium Mine, Karnes County, Texas}

The Brysch Urantum Mine (Dickinson and Sullivan, 1976) occurs in the lower unit of the Deweesville Sandstone Member of the Whitsett Formation of the Upper Eocene Jackson Group. The sandstone at the mine is approximately 70 feet thick and consists of an inlet-fill deposit (Galloway et al, 1979a). The uranium is in the basal part of the sandstone, which is overlain by Jackson muds. When discovered the deposit was close to the surface, and the oxidized ores were chiefly comprised of autunite and tyuyamuntte. The shape of the deposit suggested that it originated as a typical ore roll (Fig. 11).

According to Dickinson and Sullivan (1976), the ore-bearing sandstone is a well-sorted, medium-grained, feldspathic sandstone that was deposited in a beach environment. In general, the beach-sandstone units in the Whitsett are fine grained and the fluvial units are medium grained. The occurrence of mediumgralned sand in the lower unit suggests proximity of a fluvial source. The total thickness of the Deweesville at the mine is also greater than normal, further suggesting a nearby fluvial source. Feldspar includes plagioclase, orthoclase, sanidine, and microcline, as well as minor amounts of clinoptilolite and alpha-cristobalite. The sand also contains abundant fossil wood, sometimes in "log jams", and Ophiomorpha sp. burrows indicating marine conditions.

The source of the uranium in the Brysch deposit is considered to be the Catahoula tuff (Eargle et al, 1975). Dickinson and Sullivan (1976) suggest that the tuffaceous rocks of the Whitsett Formation may also have contributed uranium and that an intermediate source may have been older deposits. They suggest that the uranium in the deposit was carried to the depositional site through fluvial sandstones that connected the beach-sandstone host rock to updip areas. The reductant was apparently the plant material and pyrite in the beach sand. There is no evidence of introduced $\mathrm{H}_{2} \mathrm{~S}$ even though faults and oil fields occur in the general vicinity of the mine.

Deposits in the Catahoula Formation

The sediments of the Catahoula Formation in South Texas are divided into two depositional systems by the San Marcos Arch (see Fig. 3 and Plate II). Southwest of the arch, the Catahoula Formation is represented by the Gueydan fluvial system, whereas to the northeast, it is represented by the ChitaCorrigan fluvial system (Galloway et al, 1979a). Both systems are underlain by and grade into the deltaic and barrier-strand plain systems of the Frio Formation. All significant uranium occurrences in the Catahoula occur within the Gueydan sediments which are composed of a series of complexly interweaving belts of sands (Plate VII). The sand-rich portions of the formation, which contain from 10 to 50 percent sand, are represented by fluvial channelfill and crevasse splay facies. The sand-poor facies are represented by tuffaceous mudstones and claystones of flood-plain and lacustrine depositional environments. The relations between these various depositional environments are shown schematically in Figure 12. The fluvial channel-fill deposits average about 35 feet in thickness but bodies of more than 60 feet are common. These bedload channe1-fill deposits are the dominant coarse-clastic facies and are composed of coarse to medium sand with subordinate coarser cobbles and 


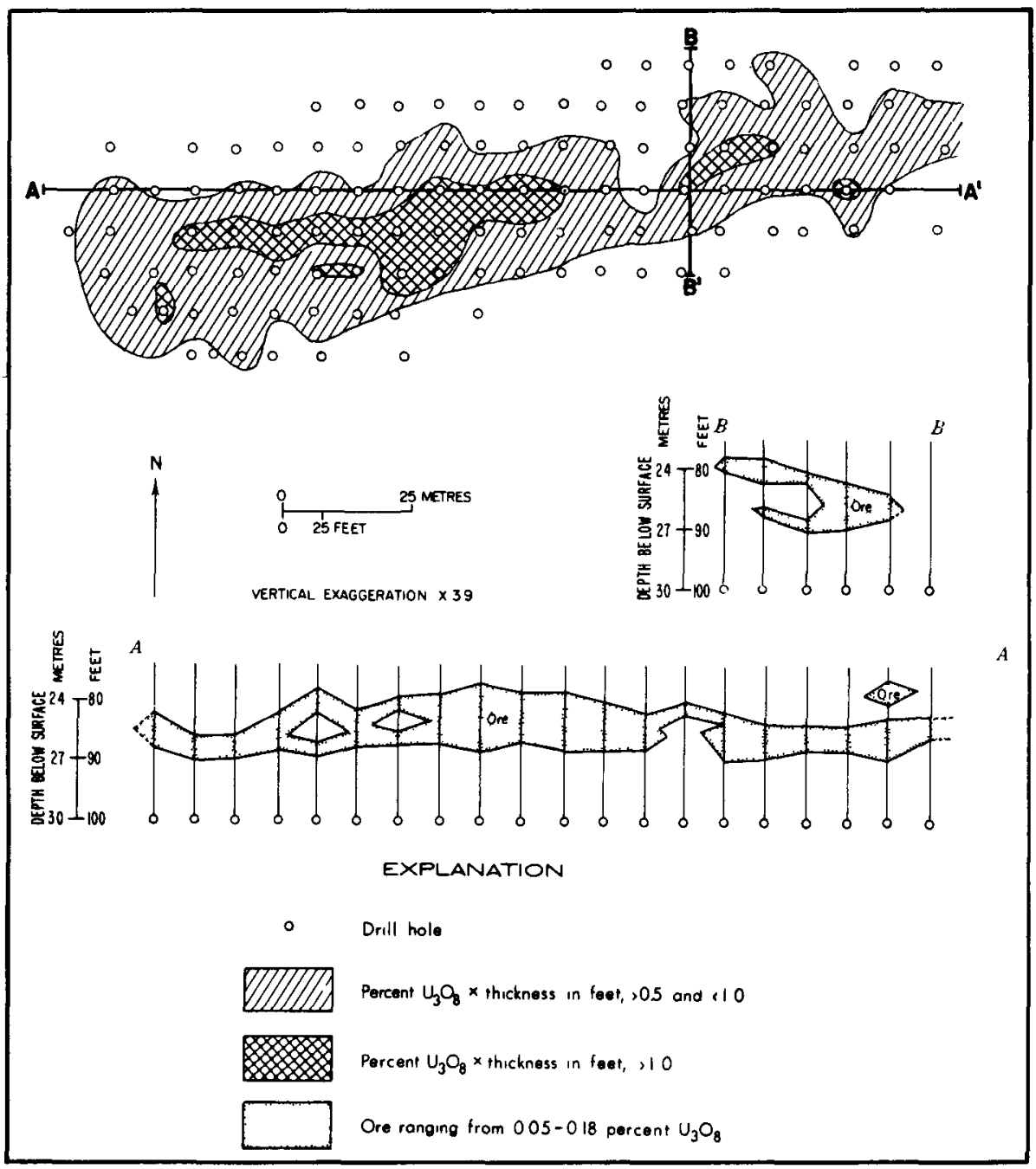

Figure 11. Map and cross section for the Brysch uranium deposit, Whitsett Formation, Karnes County, South Texas (modified from Dickinson and Sullivan, 1976). 


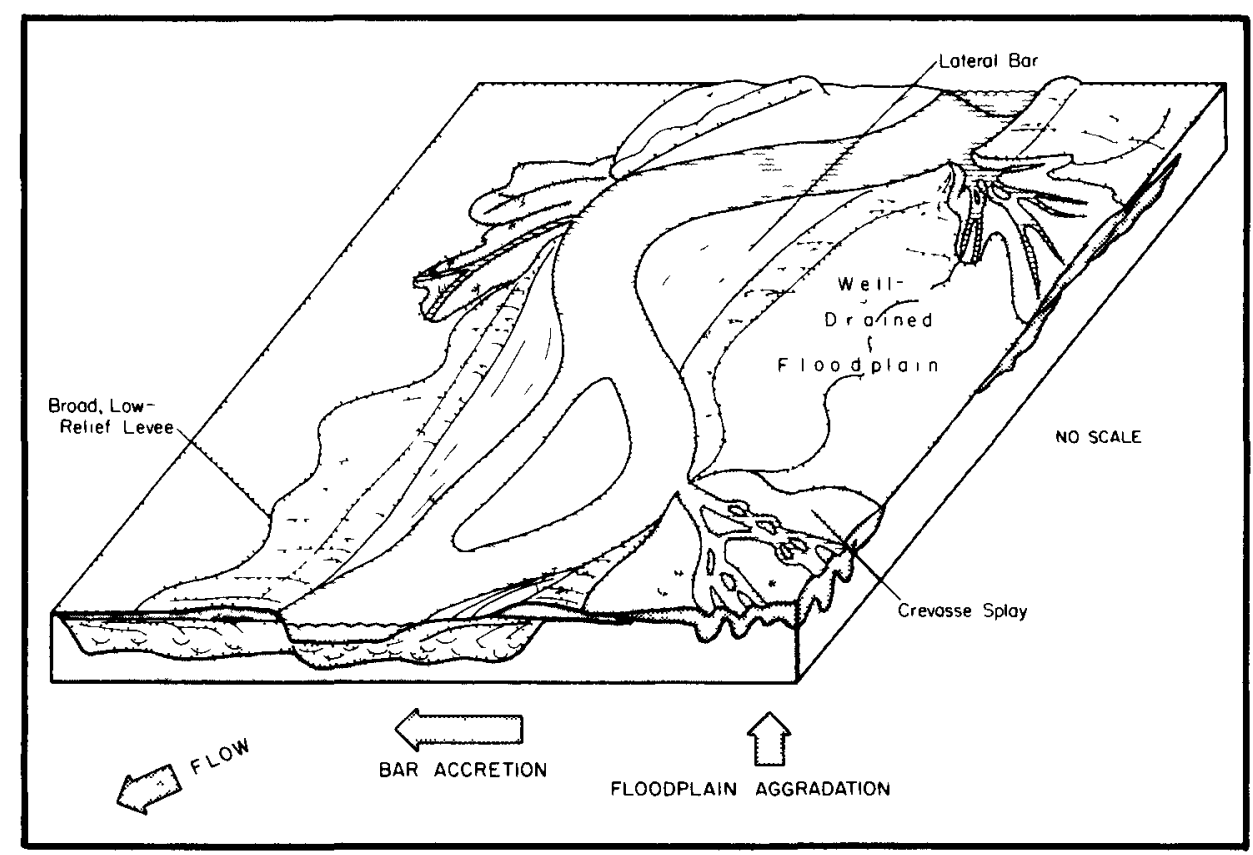

Figure 12. Schematic reconstruction of Gueydan depositional environments (modified from Galloway et al, 1979a).

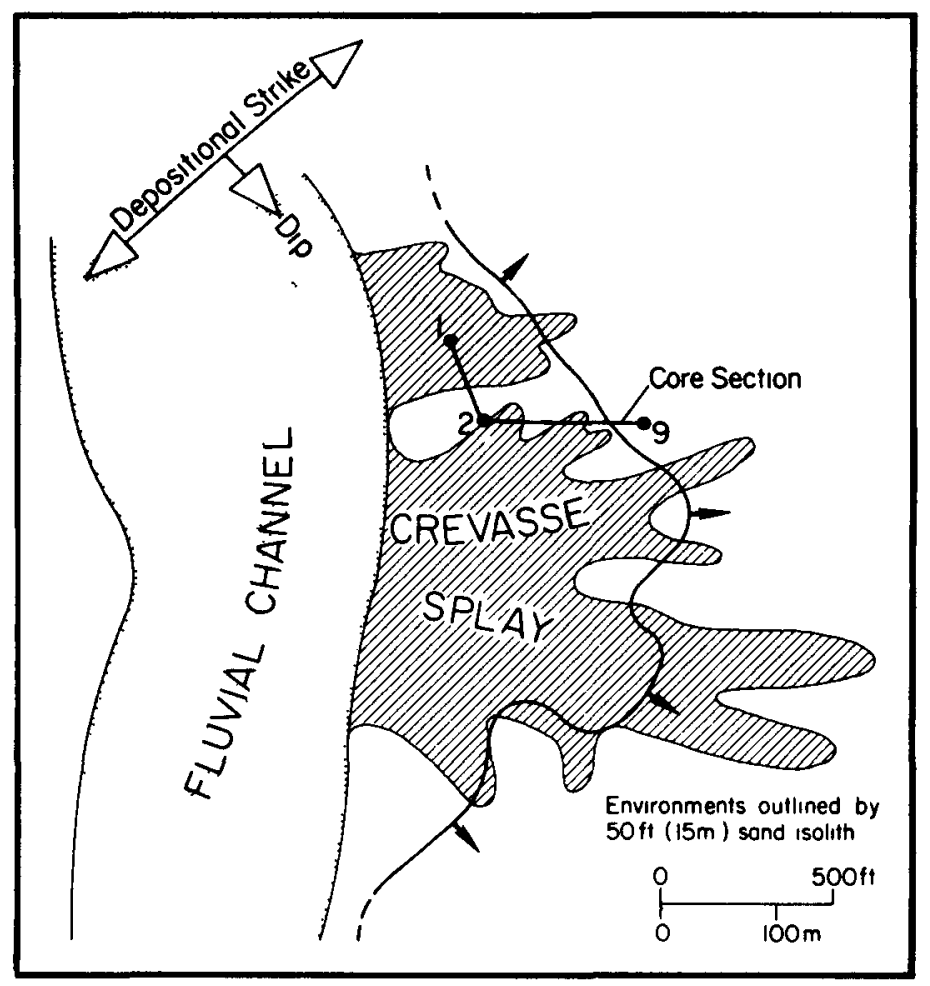

Figure 13. Geologic setting of the Washington-Fayette deposit, Catahoula Formation, showing roll-front uranium mineralization within the crevasse splay sand body (modified from Galloway and Kaiser, 1979). 
fine sand and silt. The sands were initially well sorted, but, due to the diagenetic alteration of volcaniclastic material, they are now a poorly sorted, matrix-rich sand. The crevasse splay sands extend for hundreds to thousands of feet beyond the channel margins into the interchannel areas and average a few tens of feet in thickness. The sediments range from medium to fine sand and mudstone.

Tuffaceous mudstones, siltstones, and bentonitic claystones of the flood-plain facies occupy the interchannel areas surrounding the fluvial systems. Locally, lacustrine sediments composed of bentonitic clays, tuffaceous mudstones, and lacustrine deltas are present within the Catahoula Formation.

The Catahoula Formation has been studied in considerable detail by Galloway and co-workers. Not only does this formation contain some of the largest deposits in the South Texas Uranium Reglon, but its contained volcanic material is widely believed to have been the source for the uranium deposits not only in the Catahoula but in the other major ore-bearing sediments of the regions. Important papers on the Catahoula Formation and its uranium deposits include those by Eargle and Weeks (1973); Eargle et al (1975); Galloway (1977); Galloway et al (1979a); Galloway and Kaiser (1979); Goldhaber and Reynolds (1978, 1979); and Reynolds and Goldhaber (1979).

The principal deposits in the Catahoula Formation occur in southeastern Webb County and southern Duval County (Plate VII). Minor deposits with considerable oxidized uranium occur near the surface in northern Live Oak County and small, isolated deposits and occurrences of mineralization are known in southern Jim Hogg and Starr Counties. Finally, some re-reduced deposits, somewhat unique for the Catahoula, occur in northwest Duval County in the Soledad Member of the formation.

The deposits in northwestern Duval County display a classic roll-front configuration except where they are distorted along faults. Shallower deposits are out of equilibrium in favor of radiometric assays due to recent leaching of uranium. The deposits are small in size but contain high uranium grades. Deposits are usually 1 to 10 feet thick, 150 to 200 feet wide, and have a strike length of a few thousand feet to less than a mile. Average grades of economic deposits are in the range of 0.1 to 0.2 percent $\mathrm{U}_{3} \mathrm{O}_{8}$. The migration direction of the fronts is generally downdip in a southeast direction. The ore rolls strike nearly parallel to a northeast-southwest fault system that is exposed at the surface.

The deposits in Webb and Duval Counties are within the Southern Duval Mineral Trend and are discussed in detail in a subsequent section of this report.

The deposits in northern Live Oak County occur at the base of the Catahoula Formation (Galloway, 1977). Because the host sediments of these orebodies are dominated by mudstones, clay, and ashy, fine-grained sands, the configuration of the deposits is difficult to determine. Many of the deposits are completely within reduced sandstone (i.e., pyrite-bearing) some considerable distance from tongues of altered sandstone. This suggests the sands are rereduced. Some shallow deposits do contain oxidized uranium minerals and would probably have been destroyed but for the argillic, relatively impermeable sands. The dimensions of the deposits vary greatly but are never large. The largest occurrence, the Nell deposit, occurs in several sand zones with 11ttle 
continuity, and its erratic character has been described as "ratty". Grades are usually low, averaging 0.15 percent $U_{3} O_{B}$ or less. The shallow deposits were mined by open pits and the deeper ( 500 feet) deposits by in situ leaching. The Nell deposit is currently being developed for in situ leach mining.

Galloway et al (1979a) have summarized the salient geological features related to the major clusters of uranium deposits within the Catahoula Formation. In general, mineralization is concentrated along the flanks of principal fluvial channel systems and many, but not all, deposits are related to faults. The cluster of small deposits within northern Live Oak County (Plate VII) lies in a zone of interfingering between tuffaceous crevasse splays and coastal-1ake facies at the base of the Catahoula Formation. The deposits occur on the flank of a major channel belt which trends northeast. These deposits are remote from any known faults. The deposits in northern Duval County occur at the intersection of a subsidiary channel complex and a broad fault zone. The deposits in southern Duval County occur along the margins of a major channel complex and are associated with the more argillaceous parts of the sandstones. These deposits are generally downdip from a belt of growth faults, but other faults occur substantially farther downdip. At least some of these deposits are interpreted to be related to introduced sulfides. These deposits are part of the South Duval County Trend and will be discussed in a later section. Two additional deposits in the Catahoula Formation are described briefly below.

Galloway and Kaiser (1979) have described a small deposit in the WashingtonFayette Counties area in which the mineralization occurs along an arcuate alteration front within crevasse splay sand at the downdip margin of a channel-fill sand (Fig. 13). The heterogeneity of the host has produced a complex roll-front geometry (Fig. 14). Ore occurs as discontinuous pods within a zone of diffuse mineralization along the roll front. Maximum uranium concentration occurs in or close to lenses or pockets of carbonaceous trash and humate-like material dispersed in clay. They observed that the deposit resembles the classic trash-pile accumulations of other sandstone districts, but with the uranium accumulations occurring only along the well-defined roll front. Disequilibrium occurs locally along the front. Molybdenum is concentrated along the margins of the mineralized pods, most commonly on the reduced side, and selenium is locally enriched on the oxidized side. Iron decreases in concentration from the unaltered reduced sandstone (2.1\%) to the oxidized sandstone (1.2\%). Carbonate is present in amounts exceeding 20 percent in the vicinity of mineralization, and although it may be related to ore formation, $1 t$ shows no relation to the ore zones. Volcanic detritus constitutes a minor portion of these sands.

A second deposit described by Galloway and Kaiser (1979) and Galloway (1977) is the House-Seale deposit in northern Live Oak County (Plate VII). The deposit is one of several that occur in a zone of interfingering between a major northeast-trending fluvial axis and a sequence of lacustrine ash, silt and mud (Fig. 15). The host sediments consist of crevasse splay and lacustrine delta fine sands, ash, and tuffaceous mudstone. Mineralization occurs along a series of erratic, local roll fronts that can be traced for a few thousand feet. The deposit occurs entirely within gray, pyritic sediments that extend updip for at least several thousand feet; hence, the host rock appears to be re-reduced.

No faults are immediately associated with the deposit, but a zone of growth faults is associated with the uranium deposits of the Oakville Formation in 


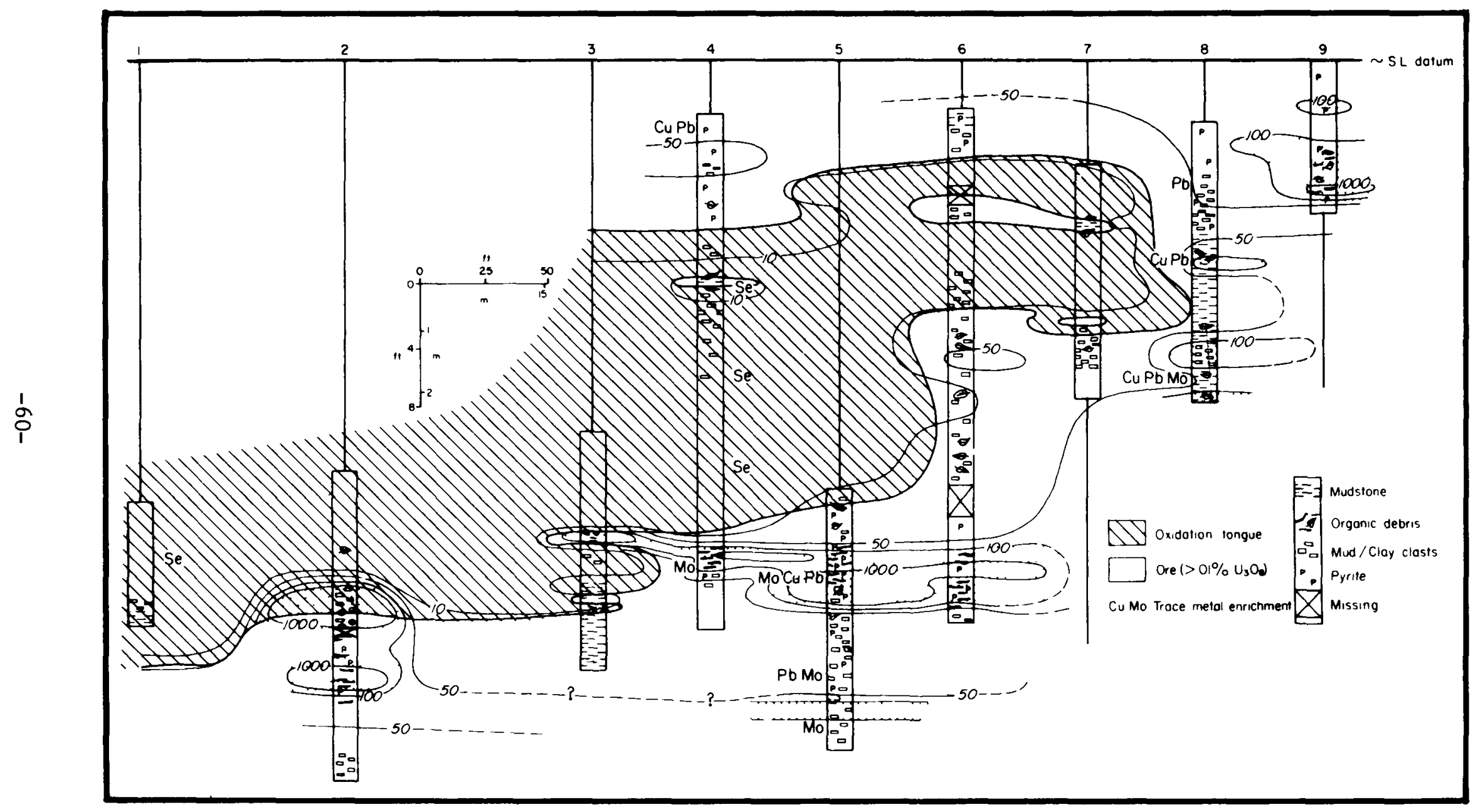

Figure 14. Diagrammatic cross section across the roll front in the Washington-Fayette deposit. Location of cross section indicated in Figure 13 (modified from Galloway and Kaiser, 1979). 


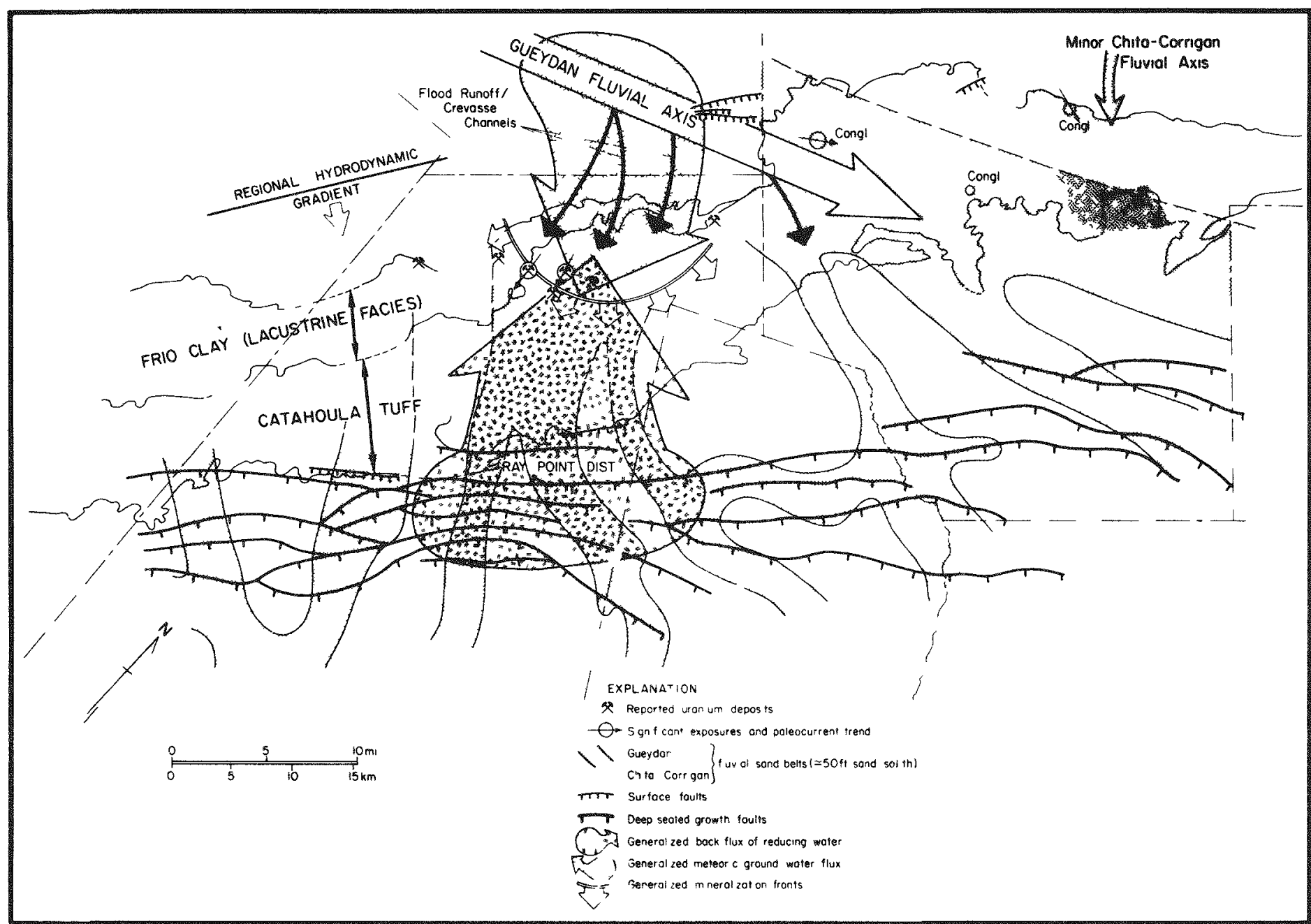

Figure 15. Geologic setting of the House-Seale deposit, northern Live Oak County. Deposit occurs in crevasse splay facies that have been reduced by north-flowing $\mathrm{H}_{2} \mathrm{~S}$-bearing waters (modified from Galloway and Kaiser, 1979). 
the Ray Point district about ten miles to the south. Several sands within the basal Gueydan trend extend northwest from this fault zone toward the HouseSeale deposit and could have transmitted the sulfide-rich waters which obviously have invaded the aquifer.

As is common, selenium and molybdenum are zoned in a downdip direction across the rolls in the House-Seale deposit. Detailed studies of a few samples suggest uranium is concentrated with matrix Ca-montmorillonite. Although the ratio of $\mathrm{Fe}_{2} \mathrm{O}_{3}$ to $\mathrm{FeS}_{2}$ is significantly higher behind the front, the characteristic oxidized tongue has apparently been masked by a post-mineral flooding of sulfide. The average content of carbon in unaltered ground is 0.1 percent, in altered ground 0.03 percent. Uranium concentration shows no correlation with organic carbon content. The host sediments include claystone, tuffaceous mudstone, muddy siltstone, and argillaceous fine sand characterized by partly altered and vitric volcanic debris. Some fresh glass is present within the ore zone. As at the Bruni deposit, a pre-mineral stage of sulfidization is inferred in this deposit. Oxidizing solutions subsequently moved down the fluvial channel and formed a roll front against the finer grained sediments of the marginal crevasse splay and crevasse delta. At a later time reducing fluids again flooded the aquifer to produce the present re-reduced host sands. An alternate interpretation suggests that the leaching of uranium may precede the oxidation of pyrite so that a uranium roll could be formed entirely within pyrite-bearing sands. This would be favored by roll-front formation in alkaline solutions (Fig. 29). Existing data suggest, nonetheless, that postore $\mathrm{H}_{2} \mathrm{~S}$ has been introduced in some of the deposits studied; thus we prefer this interpretation.

Deposits in the Oakville Formation

The largest uranium deposits in the Oakville Formation occur in Live Oak and McMullen Counties (Plate VIII). A few small deposits occur to the northeast in northern Bee County, and, in a later section, we will discuss some Oakville deposits in southern Duval County. Uranium occurrences in the Oakville Formation have been discussed by many authors including Klohn and Pickens (1970); Eargle and Weeks (1973); Eargle et al (1975); Ga1loway et al (1979a); Goldhaber and Reynolds (1979); and Goldhaber et al (1979).

Orebodies in the Oakville Formation are usually quite large. The Ray Point district in northern Live Oak County, for example, is essentially one orebody that is divided by property lines (F1g. 16). This deposit is usually about 12 to 15 feet thick and widths range from a minimum of about 100 feet to 300 feet. The deposit is not economic for its entire length but is continuously mineralized for almost 4 miles. The average ore grades depend on exploftation method but generally are in the range of 0.15 to 0.20 percent $U_{3} O_{8}$. The greatest concentration of uranium mineralization is always within the basal sands of the Oakville Formation (Fig. 17). Isolated, smaller deposits are known to occur in sands near the middle of the Oakville within the Ray Point district.

Deposits in the Clay West district, approximately $18 \mathrm{miles}$ southeast of the Ray Point district, contain slightly more reserves at approximately the same average grade. The individual deposits are shorter but wider than at Ray Point due to faults that have broken the long roll fronts into a series of shorter deposits. The ore minerals are reported to be uraninite and coffinite. 


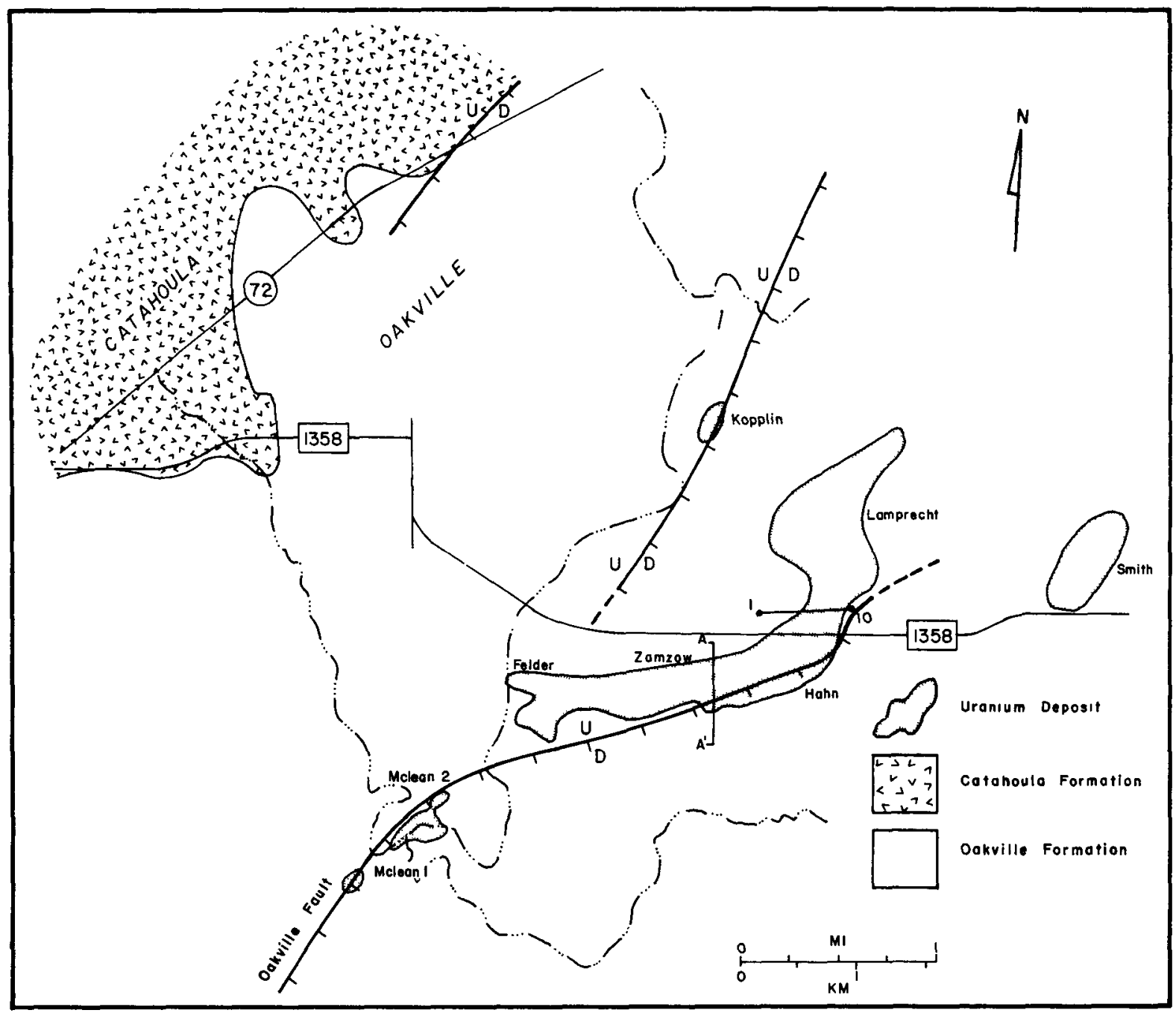

Figure 16. Geologic map of the Ray Point district showing approximate outlines of uranium deposits, South Texas (modified from Galloway et al, 1979a).

The uranium deposits in the 0akville Formation occur more commonly entirely within pyrite-bearing sandstones than those of any other formation. Goldhaber et al (1979) studied the Lamprecht deposit and found at least three and possibly a fourth stage of iron disulfide mineralization. Some of the deposits in the Clay West district also occur entirely within reduced sandstone. The Rhode Ranch deposit in McMullen County is totally within re-reduced sands, and the multiple roll fronts in this deposit suggest it may have been reduced three and possibly four times. The only oxidation associated with mineralization results from surface oxidation of shallow mineralization.

All of these districts and deposits are closely associated with a major fault zone extending the length of the South Texas area. In northern Live Oak County 


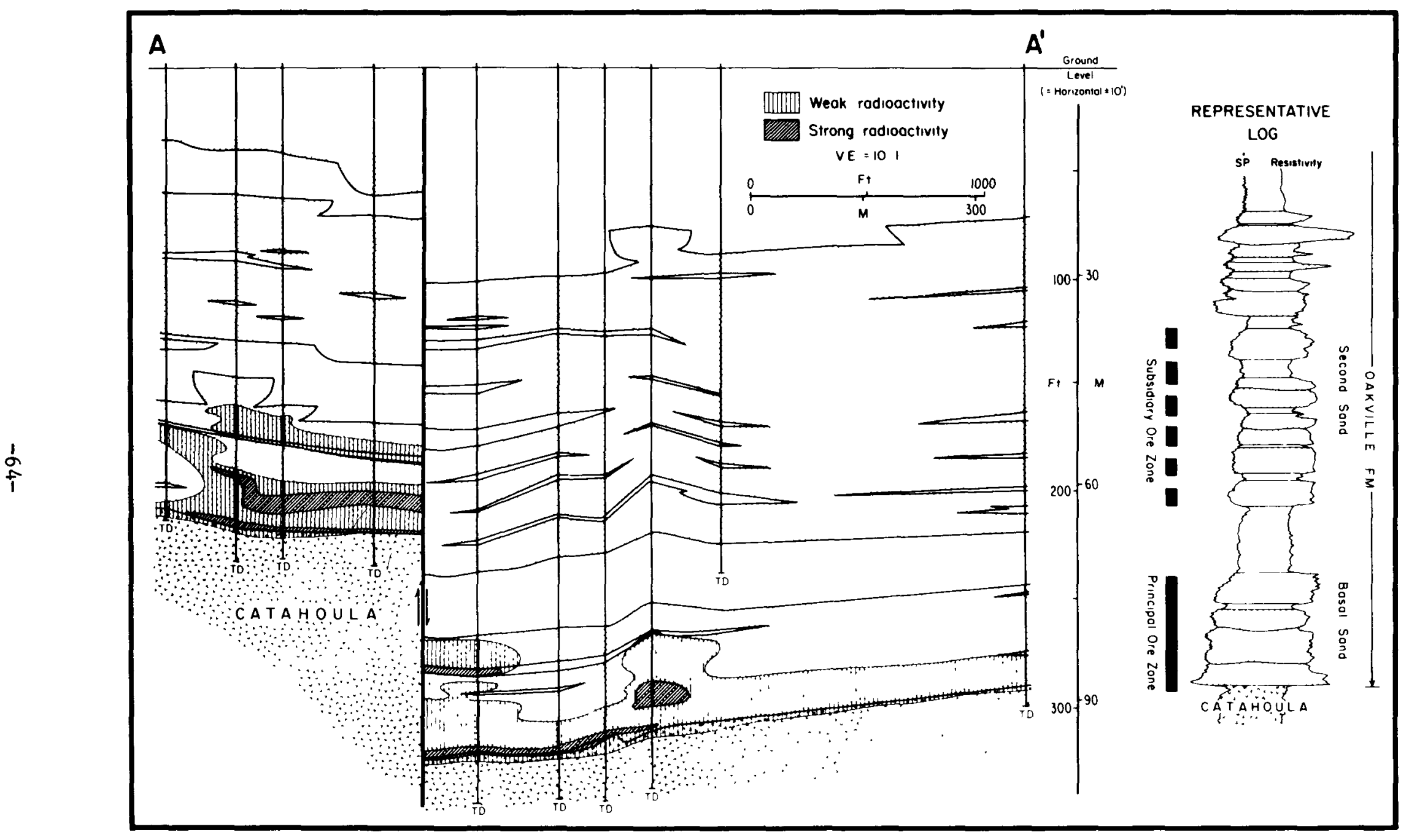

Figure 17. Cross section through the Zamzow Deposit, Ray Point uranium district, South Texas. Location of cross section shown on Figure 16 (modified from Galloway et al, 1979a). 
the Oakville fault, a down-to-the-coast fault, runs through or close to the mines on the north, and an up-to-the-coast fault runs through the deposits on the south, forming a wide graben that extends northeastward through Live Oak County. Two of the northern mines (McLean 1 and Kopplin) are cut by faults and two others (McLean 2 and Felder) are within half a mile of a fault. The two southern deposits (Clay West and Burns) are close to a fault.

Several of the deposits contain post-fault mineralization and in the McLean Mine, high-grade mineralization occurs within the fault gouge for several meters depth. Figure 17 shows an orebody offset by movement on the Oakville fault.

Galloway et al (1979a) describe the Oakville as having been deposited in a bedload fluvial system comprised of several coastal-plain rivers. Downdip toward the paleocoastline, the fluvial sediments grade into equivalent strandline facies of deltaic and barrier-bar sedimentary systems (Plate VIII). The host sands are generally composed of bed-load and mixed-load channel fills and associated crevasse splay units. The less permeable units marginal to the channel axes include heterogeneous distal crevasse sequences, abandoned channels, channel-margin levees, and calcareous flood-plain muds. The clay minerals of these sequences are dominantly montmorillonite with variable amounts of kaolinite and subordinate illite.

Uranium deposits within the Oakville Formation occur as sinuous roll fronts near the margins of major fluvial sedimentary axes. The major districts occur in the vicinity of faults, but not all deposits are associated with known faults. Larger deposits appear to be associated with larger, more transmissive host sandstones.

The principal uranium deposits in the Oakville Formation, excluding those in the South Duval County Mineral Trend, are shown in Figure 18. Identifying numbers for the Clay West/Burns district (1) and the Ray Point district (2) are indicated. Location 3 is a small deposit in the Lower Oakville sands that occurs along a minor fluvial axis but is not associated with any known structure (Galloway et al, 1979a). At location 4, the uranfum-bearing host sands occur in a transition zone between Catahoula and Oakville 1ithologies. Although they are included within the Oakville in regional mapping, they lie stratigraphically lower than other basal Oakville sands. The deposits occur in a thick sand near the margin of an oxidized fluvial axis and are associated with faults.

Bomber et al (1980) have investigated the McLean 5 deposit in the Ray Point district. The deposit occurs in the oakville Formation adjacent to a fault. The major detrital constituents are quartz, feldspar, and rock fragments which are accompanied by authigenic zeolites, micritic calcite, pyrite, marcasite, and clays. In low-grade mineralization, uranium occurs adsorbed on titanium oxides, principally leucoxene, altered rock fragments, and clay galls. In higher grade ores, uranium, principally as pitchblende, coats grains. Molybdenum is enriched in the ores, and some uranium occurs within opaline matrix cement.

Many uranium deposits within the Oakville Formation occur completely within reduced sands. Recent studies by Goldhaber et al (1979) on the Lamprecht deposit in Live Oak County have largely explained these unusual ore occurrences (Fig. 16). They demonstrated that the geometric shape of the deposit 


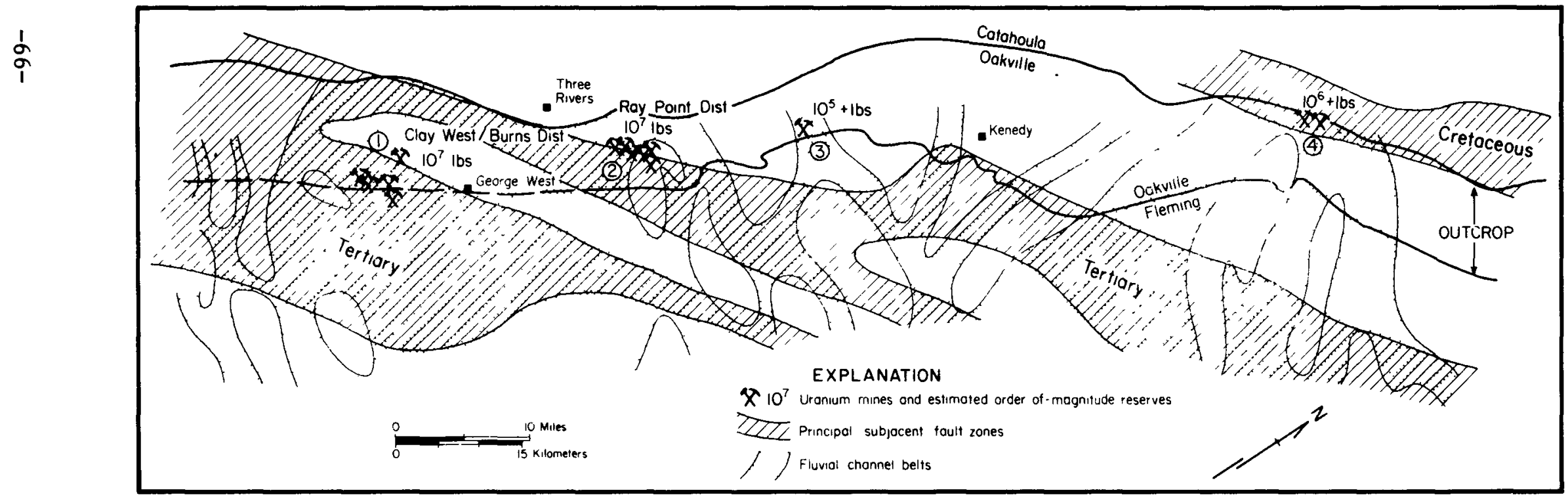

Figure 18. Distribution of uranium deposits in the Oakville Formation, South Texas (Ga1loway et a1, 1979a). 
and the suite of elements zoned across it are typical of roll-type deposits that occur at well-developed oxidation-reduction boundarles (Fig. 19). This suggests that these deposits are formed by the customary roll-front mechanism. They have also provided evidence that prior to roll-front development $\mathrm{H}_{2} \mathrm{~S}$ was introduced into the oxidized host sand forming a pre-ore stage of pyrite. Oxidizing waters moving within the host sand impinged upon these reduced pyrite-bearing sediments and formed the roll front. As part of the ore-forming process, marcasite was deposited downdip in the sands adjacent to the roll front and synchronous with ore formation. At a later time additional $\mathrm{H}_{2} \mathrm{~S}$ was introduced into the aquifer. It combined with hematite and limonite in the oxidized updip sands producing a re-reduction of the altered tongue and leaving the deposit completely within reduced sandstone. These conclusions of Goldhaber et al (1979) are convincing and appear to explain the origin of this and similar deposits entirely within reduced sands of the Oakville and other formations in South Texas. Recent work (Goldhaber, personal communication, 1980) suggests that pre-ore sulfides in at least one of the deposits are isotopically light, suggesting they were derived from shallower sources than the Edwards Limestone and may have resulted from sulfate-reducing reactions in shallow aquifers.

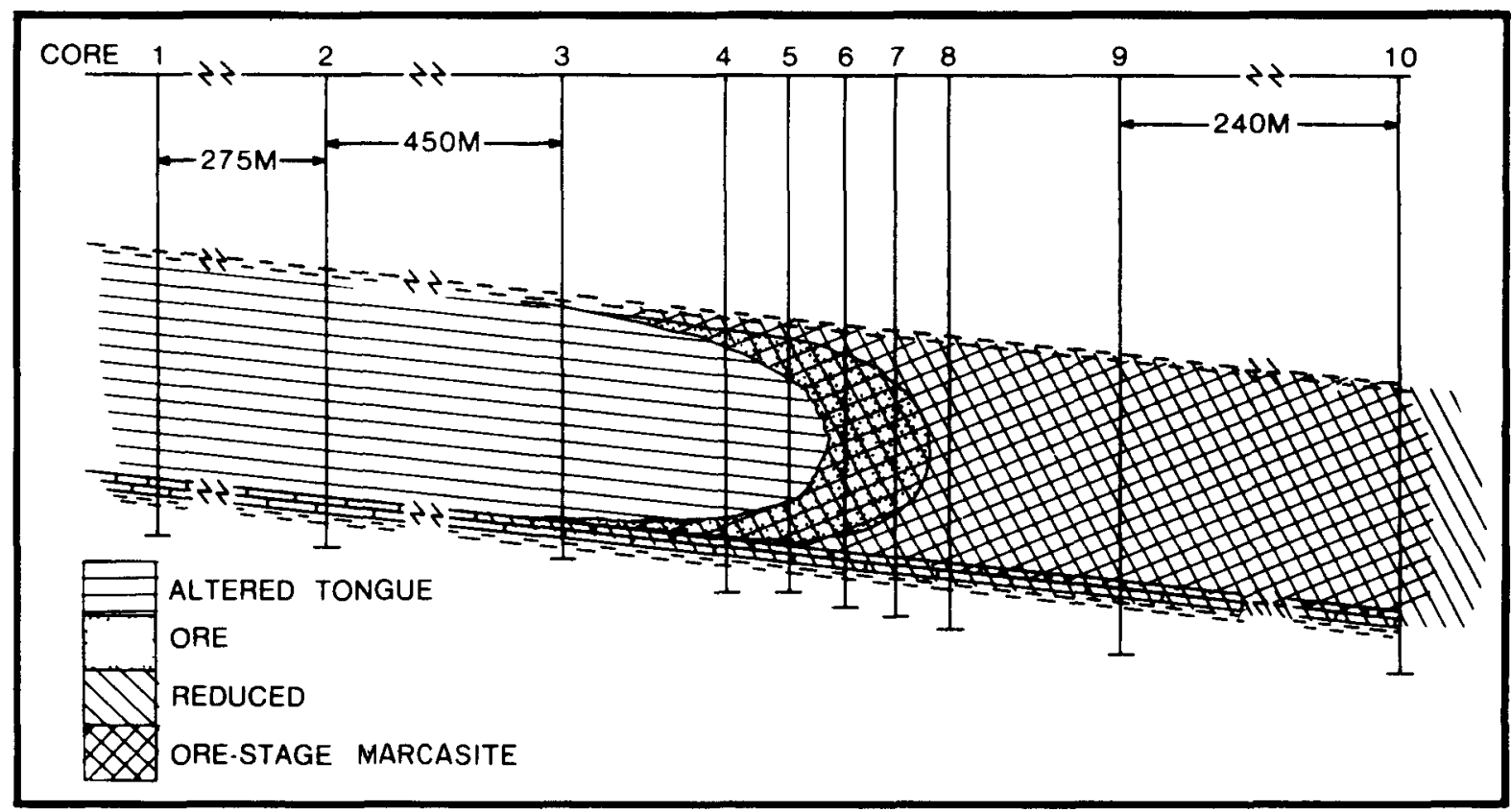

Figure 19. Cross section through the Lamprecht uranium deposit, Ray Point district, showing roll front and alteration, South Texas (modified from Goldhaber et al, 1979). 
Klohn and Pickens (1970) have presented an excellent description of the Felder deposit in Live Oak County which is in the basal sands of the Oakville Formation, also in the Ray Point district (Fig. 16). The host sand is a fineto medium-grained, moderately sorted, carbonate-rich arkose which locally contains large clay galls, clay lenses, and stringers and is composed of quartz with lesser amounts of chert, feldspar, detrital carbonate, and finegrained volcanic fragments. Organic carbonaceous debris is virtually absent within the host sands.

The Felder deposit occurs marginally to a major southeast-trending alluvial sand system, the central portion of which reaches a thickness of approximately 300 feet (Fig. 20). This axis of coarser sediments is flanked on both sides by interbedded sand and clay, which ultimately give way to predominantly clay and silt. The deposit is in this zone of interbedded sand and clay. Figure 21 presents cross sections for the deposit showing the attitude of the roll fronts.

The ore zone is between two faults, the major of which is approximately 1,500 feet to the southeast and along which the Oakville is displaced approximately 110 feet. A persistent enrichment of molybdenum occurs approximately 1,000 feet downdip from the roll front and may occupy a band of sandstone up to 1,000 feet wide. Anomalous concentrations of selenium are also present in the vicinity of a deposit but are erratically distributed.

The Felder deposit occurs well within reduced sandstone some distance downdip from an oxidation-reduction boundary. Klohn and Pickens recognized that, in the virtual absence of carbonaceous material, the pyrite-bearing sandstone in which the deposit occurs probably resulted from the introduction of $\mathrm{H}_{2} \mathrm{~S}$. Observations on the distribution of Fe-Ti oxides demonstrated that these detrital phases are still present in the updip oxidized sands but rapidly disappear downdip within the reduced sandstone. Some pyrite appears to be magnetic, suggesting that residual cores of magnetite may be present in some of the sulfidized grains. These relations are compatible with those of Goldhaber et al (1979), discussed earlier. Klohn and Pickens (1970) suggested, however, that the displacement of the uranium roll front from the oxidation-reduction boundary was a function of the low Eh gradient rather than the re-reduction of oxidized sandstone. Goldhaber et al (1979) had the benefit of more detalled mineralogic and geochemical data in their studies of the Lamprecht deposit, and we accept re-reduction as the most plausible explanation for the occurrence of deposits entirely within reduced sandstone. Recent studies by Reynolds et al (1980) suggest that the age of ore formation was $5.07+0.15 \mathrm{~m} \cdot \mathrm{y}$. ago, and that two stages of post-ore sulfidization have occurred. - One is represented by isotopically heavy sulfur-bearing pyrite in the re-reduced sands and the other by isotopically light sulfur-bearing marcasite. The source of the heavy sulfur is interpreted to have been the Edwards Formation. The light sulfur may have been derived from the Carrizo or Wilcox Formations, and light sulfur-bearing ground waters are now present in the mine area.

\section{Deposits in the Goliad Formation}

Uranium orebodies have been known within the sands of the Goliad Formation for several years, but this formation has not recelved extensive exploration 


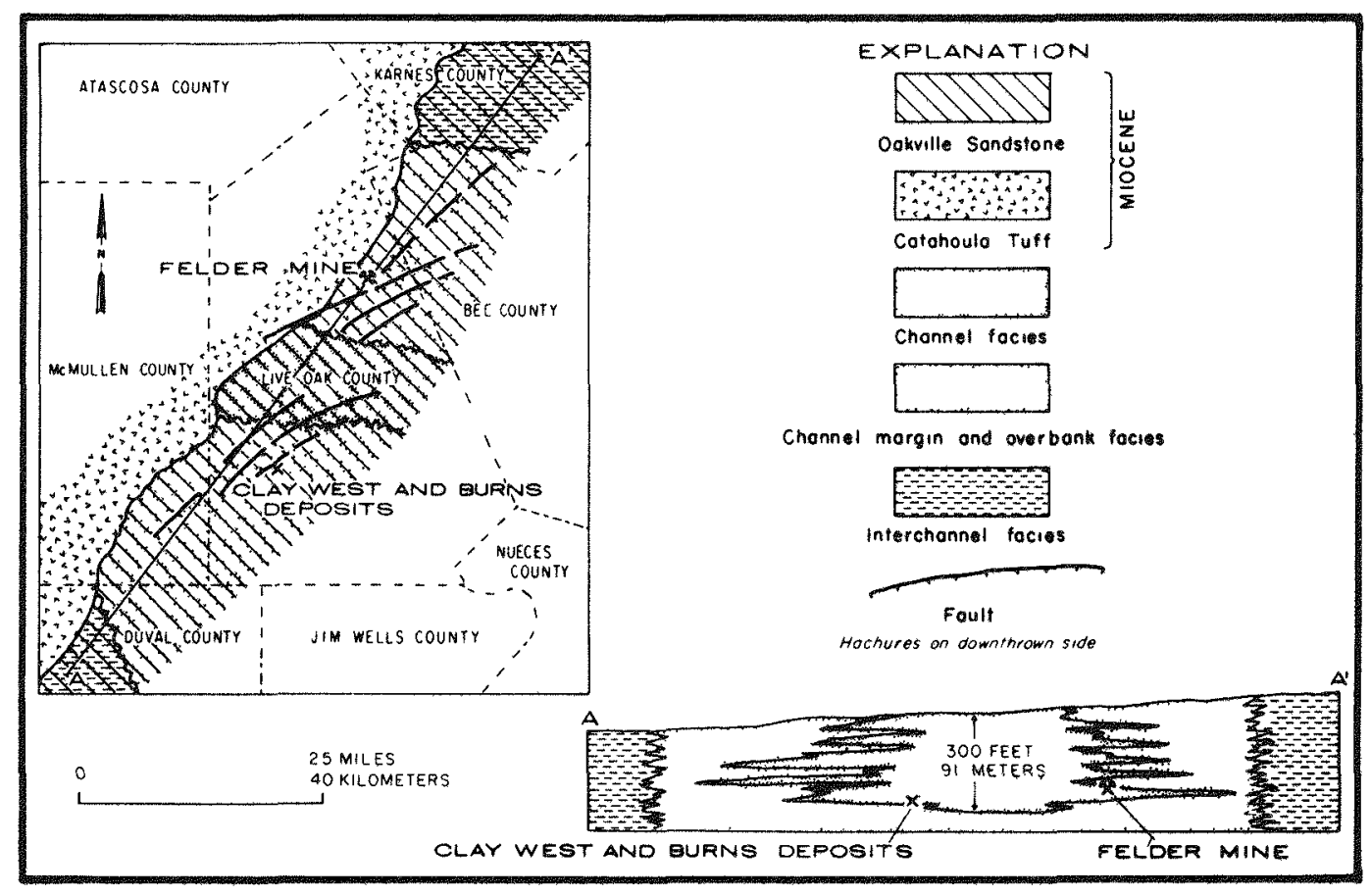

Figure 20. Map and cross section showing relations of various fluvial facies in the Oakville Sandstone (from Klohn and Pickens, 1970; modified by Eargle et a1, 1975).

because of its young age (Pliocene?), its reputation for difficult drilling and its position off the South Texas Mineral Trend (Plate IX).

The largest Goliad orebody and the model for most Goliad exploration has been the deposit at Palangana Dome (Plate I). Several other occurrences are known in the formation, but all are still in the exploration stage and few data are available on their geology. It is reported that where mineralized the Goliad contains four to six well-developed channel sands and usually four of these sands contain ore-grade uranium concentrations. Some mineralized areas are associated with salt domes, as at Palangana Dome, Sejitas, and Piedras Pintas; but others, such as those at Swinney Switch and Mt. Lucas, are not.

Mineralization at Mt. Lucas is reported to occur as roll fronts in three or four sands at depths between 150 feet and 450 feet. The positions of the fronts in the different sands are unrelated to those in overlying or underlying sands, and they apparently cross back and forth above one another. The same is apparently true at sejitas as will be discussed subsequentIy. The Palangana Dome is a shallow piercement structure that also has uranium mineralization in three fronts that occur successlvely deeper off the flank of the dome.

The Palangana Dome has been formed by a salt-plug intrusion that pierced all Tertiary sediments except the Goliad and then subsided after Goliad time (Fig. 22). The Goliad Formation is also reportedly draped slightly over 


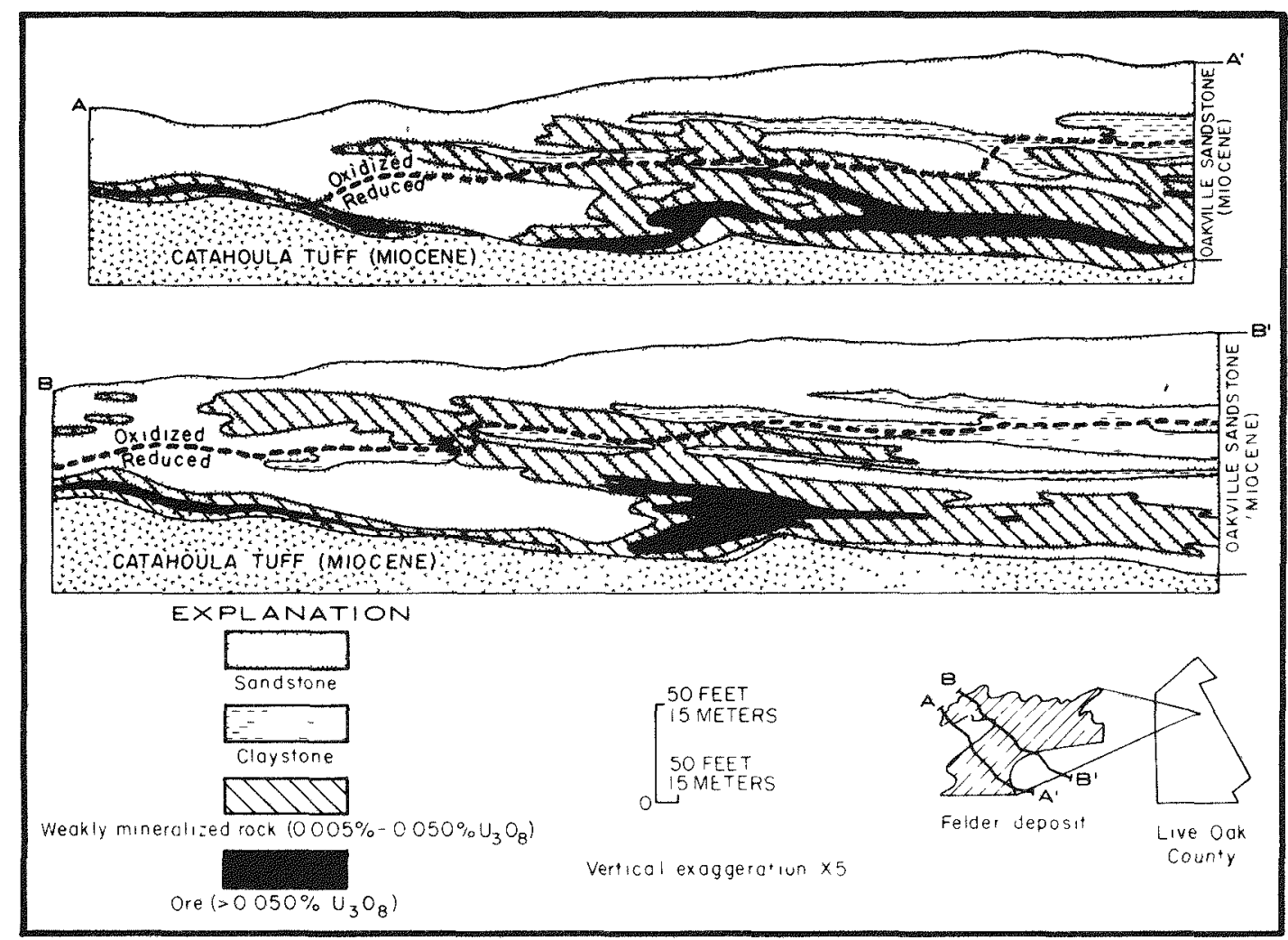

Figure 21. Cross sections through the roll front in the Felder uranium mine, Live Oak County, South Texas (from Klohn and Pickens, 1970; modified by Eargle et al, 1975).

the structure. That the dome was a positive area at the end of the Miocene is evidenced by the weathered anhydrite encountered in drill holes that cut the nonconformity between the Miocene Fleming Formation and the anhydrite of the intrusion. The distribution of sands indicates that the positive area of the dome bifurcated a major channel system during Goliad time. The relief was so slight, however, that both channels occur over the diapir.

Orebodies occur as typical roll fronts at the interface between secondary oxidation and reduction within the channe1 sands on the updip western and southwestern side of the dome. Roll fronts are reported to be en echelon in sands at depth ranging from 200 to 350 feet. Figure 22 schematically shows the position of mineralized zones. The sands are up to 50 feet thick but contain numerous, discontinuous clay lenses with thicker clays between the sands. It is not known if the roll fronts at Palangana Dome are each separate fronts or if they are part of a major roll-front system similar to the one 
described in the Gas Hills district in Wyoming. The same question applies to the other Goliad deposits at Mt. Lucas, Swinney Switch, and Sejitas.

During the 1930s, Palangana Dome produced 240,000 tons of sulfur by Frasch mining. About the same time, oil was discovered trapped in Tertiary units around the flank of the dome. A brief attempt at underground uranium mining was terminated because of abundant hydrogen sulfide in the mine workings. Attempts were then made to exploit the deposit by in situ leaching. Following the construction of a pilot plant and its expansion to a production facility, operations were terminated, reportedly because of fractures and clay partings that disrupted permeability and deflected the leach solutions.

Very little appears in the literature regarding uranium at Palangana Dome. One brief article by Weeks and Eargle (1960) is the most comprehensive reference. They describe the mineralization as disseminated, sooty pitchblende in a highly calcareous, clay-gall conglomerate interbedded with friable sand locally impregnated with a little oil. The conglomerate contains black chert pebbles, nodular chalcedony, and a few fossilized bones and teeth from fauna correlated with the basal units of the Goliad Formation.

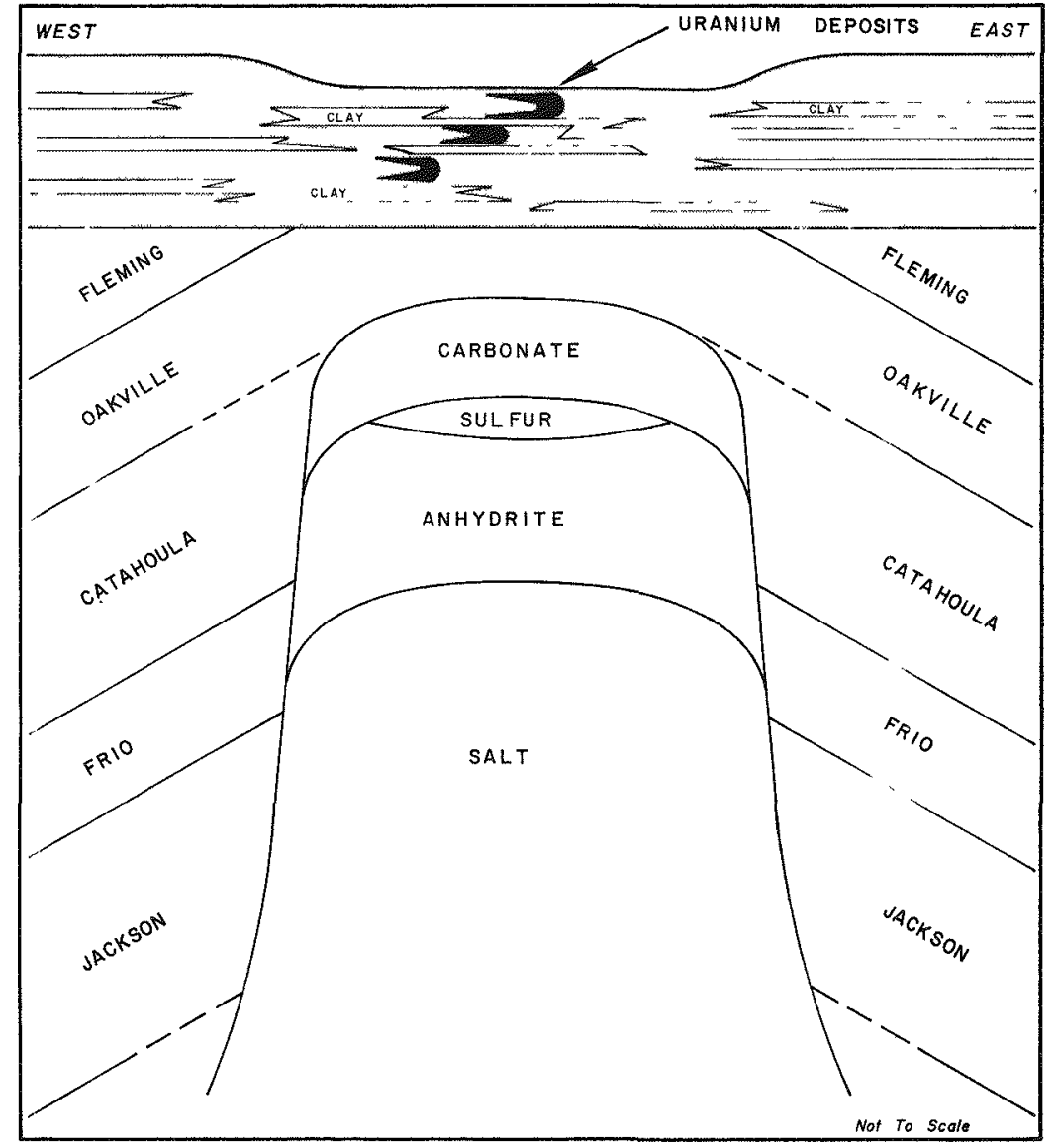

Figure 22. Schematic cross section of the Palangana Dome and associated uranium deposits, Duval County, Texas. 
Considerable importance has been attached to the salt diapir at Palangana, but its association with uranium may be remote and indirect. It appears to have been important as a site of fracturing that permitted the introduction of reductants into the aquifers, but that has occurred elsewhere in South Texas without the presence of salt. The reductants may have been $\mathrm{H}_{2} \mathrm{~S}$ derived from deeper formations or $\mathrm{H}_{2} \mathrm{~S}$ produced from the anhydrite and gypsum of the dome by sulfate-reducing bacteria. There is no report of re-reduction in the Gollad sands. 
The South Duval County Mineral Trend, as presentiy defined, extends for about 35 miles east-southeast from southeastern Webb County to northeastern Brooks County (Plates I and X). The western limit of the trend coincides with the outcrop of the Soledad Member of the Catahoula Formation. The southeastern limit may be an artifact of inadequate exploration and the trend may ultimately be extended to the southeast with further drilling. The margins of the trend are believed to be the approximate edges of major channel sands within each of the formations that comprise the ore-bearing portion of the stratigraphy. The superposition of the fluvial sands in each of the formations is believed due to some fundamental control, perhaps structural, that maintained the major fluvial systems in relatively the same position for millions of years. In each successively younger formation, the fluvial sands are interpreted to extend farther down the depositional axes toward the Gulf before they interfinger with and give way to marine sediments. To the extent that these superimposed sands are in hydrologic communication, they may constitute "interformational aquifers" which rise across the stratigraphy toward the Gulf. This en echelon stacking of fluvial sands is, for lack of a better term, referred to in this report as a mega-channel. Plate $X$ shows the position of this mega-channel together with known uranium deposits.

The South Duval County trend contains one of the largest uranium deposits in South Texas as well as several smaller but important deposits in at least three different geologic formations. There are several similar trends in South Texas which, to the extent that they share geologic characteristics, offer potential comparable to the South Duval County trend.

The major fluvial channel systems in the Jackson Group and the Catahoula, Oakville, and Goliad Formations in the vicinity of the South Duval County trend are shown in Plates VI through IX. The channel in the Jackson Group is west of the area of known deposits, but its presence Indicates that the sedimentary axis of the trend had been established as a fluvial channel system at least as early as Eocene (Plate VI). The Jackson Group is separated from the Catahoula Formation in this area by the impervious Frio Formation which may account for the absence of uranium deposits in the Jackson sands. Reference to the lithofacies maps for the Catahoula and younger formations (Plates VII to IX) indicates that the trend was similarly the site of a channel sand for each of these formations.

\section{Deposits in the Catahoula Formation}

The subsurface distribution of sands along the South Duval County Mineral Trend is shown in Plate XI, a diagrammatic section based on data from ofl we11s. The accumulation of sand in the Fant Member of the Catahoula Formation is shown near the updip end of the section. These sands represent either a continental fluvial channel system or a prodelta sequence that accompanied the marine regression following Frio deposition. 
The sands within the Soledad Member of the Catahoula Formation represent deposition even more distant from a marine environment. Gravels occur throughout the Soledad Member in the South Duval County trend and occupy stratigraphically higher positions downdip toward the southeast. These gravels are believed to have influenced ground-water migration and transportation of uranium.

The host sands of the Soledad Member are composed of coarse gravels, 2 to $3 \mathrm{~mm}$ In size, containing moderate to abundant black chert and volcanic fragments. Some of the gravel units are 70 to 80 percent black chert pebbles and cobbles. The gravels grade upward into medium- to fine-grained, subangular to wellrounded sand composed of chert, quartz, volcanic fragments, and minor mafic minerals. Much of the interstitial material is montmorilionite and illite.

The Chusa Member of the Catahoula Formation overlies the Soledad Member and is primarily a tuffaceous unit formed by air fall and/or fluvial deposition. Prominent sands in the Chusa occur only downdip over the marginal marine sequence of the Soledad.

The stratigraphic positions of the uranium deposits within the South Duval County Mineral Trend are also shown in Plate XI. Along the trend from west to east there is a rise in the stratigraphic position of the deposits. The Santonino and Bruni deposits (off the section to the west) occur in the basal sands of the Soledad Member of the Catahoula Formation (Fig. 23). The Benavides, O'Hern, and Holiday-El Mesquite deposits further along the trend to the east (Plate X) occur higher in the Soledad Member as indicated in Plate $X I$.

Galloway and Kaiser (1979) describe the Bruni uranium deposit as occurring at an oxidation-reduction boundary within a proximal crevasse splay sand sequence that is approximately 45 feet in thickness. The mineralization along the front has been traced for more than two miles. The shape of the deposit is the typical roll form, and elements are concentrated across the roll front in the customary fashion (Harshman, 1974), i.e., from selenium adjacent to the altered tongue through vanadium and uranium to molybdenum some distance beyond the roll front. The host sand is a plagioclase-rich volcanic litharenite.

Companion papers by Reynolds and Goldhaber (1978) and Goldhaber and Reynolds (1978) describe the results of excellent mineralogical and geochemical studies in the Benavides deposit. The deposit is a typical roll-type deposit occurring at the boundary between downdip-reduced sandstone and updip-oxidized sandstone (Fig. 24). They investigated the Fe-Ti oxide minerals and their post-depositional alteration products for a distance of $1.7 \mathrm{~km}$ across the roll front. In reduced rock in front of the roll, they found that titano-magnetite and, to a lesser extent titano-hematite, had been replaced by pyrite and marcasite. Behind the roll, for a distance of approximately $210 \mathrm{~m}$, the sands contain abundant limonite but no titano-magnetite or sulfides. By contrast, $1 \mathrm{~km}$ updip from the roll front the sands contained titano-magnetite and martite, with no evidence that they were ever sulfidized. The evidence suggests, therefore, that heavy minerals were originally sulfidized up to a point at least $210 \mathrm{~m}$ but less than $1 \mathrm{~km}$ behind the present roll front, and that oxidizing solutions subsequently invaded the sandstone, partially oxidized the titano-magnetite well updip from the deposit, and completely destroyed the 


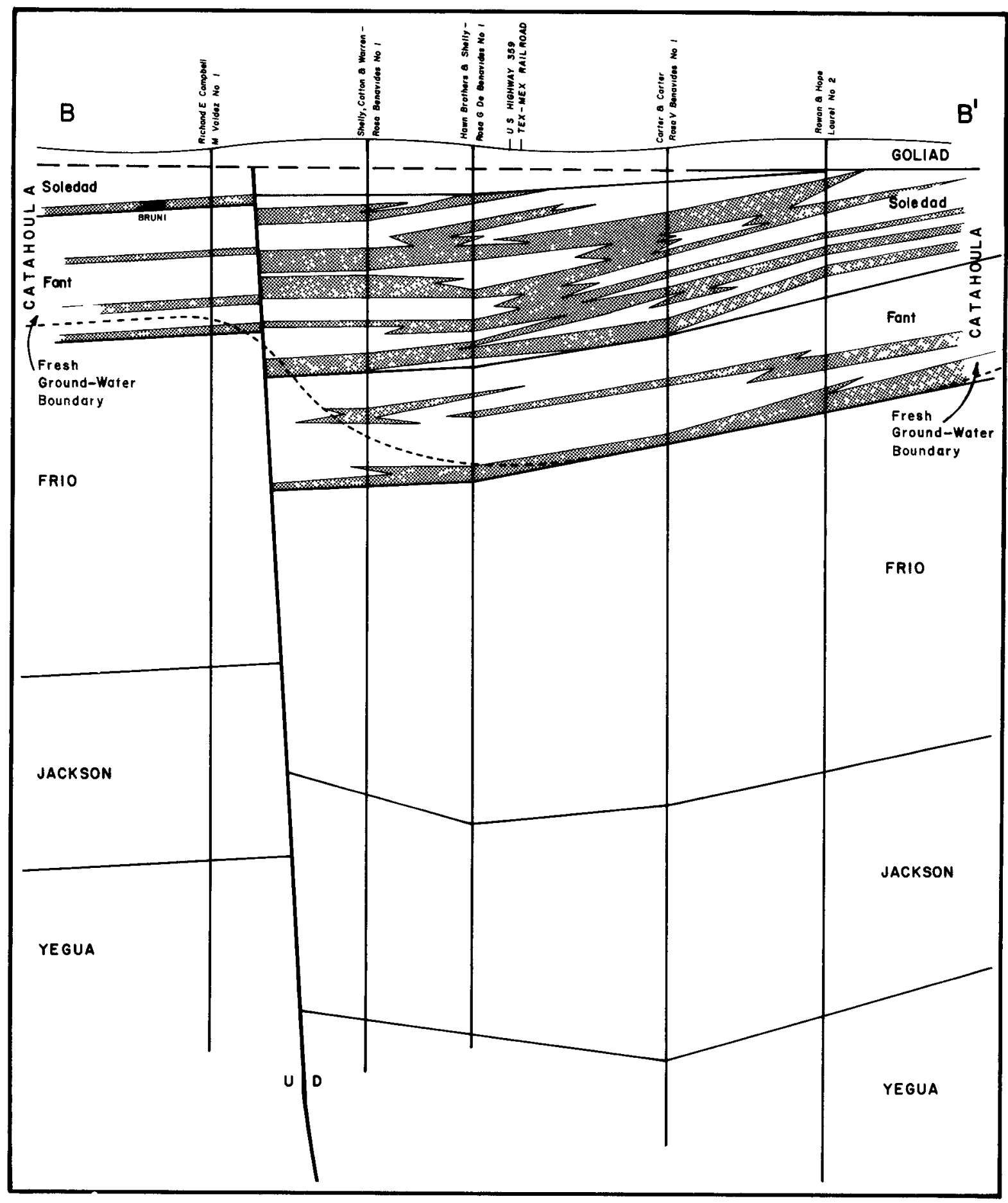

Figure 23. Schematic cross section ( $\left.B-B^{\prime}\right)$ across the South Duval County Mineral Trend. 


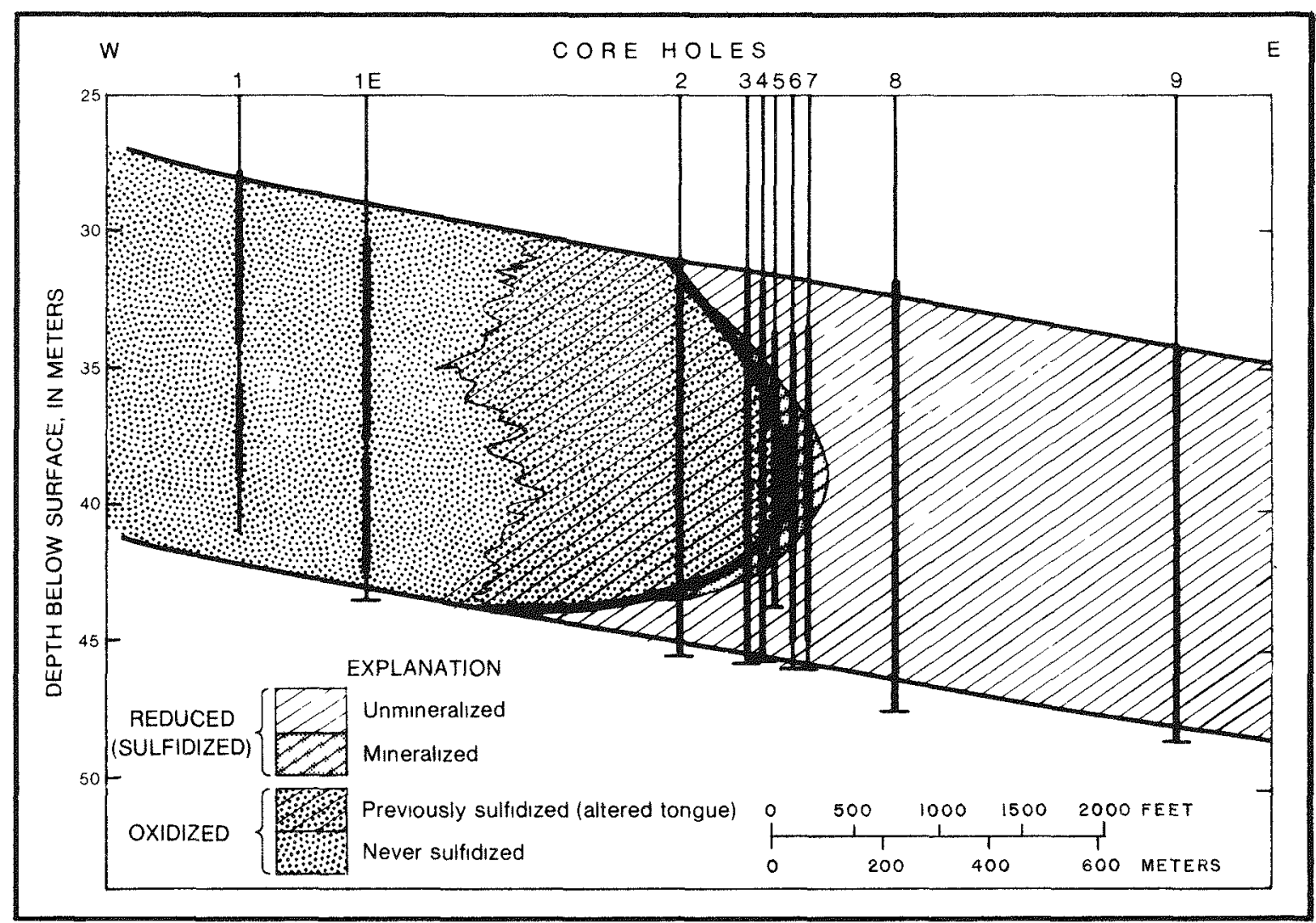

Figure 24. Cross section of the Benavides deposit showing the distribution of the major chemical zones. Sampled portions of core are shown in heavy lines (modified from Reynolds and Goldhaber, 1978).

sulfidized titano-magnetite for a distance of at least $210 \mathrm{~m}$ during the propagation of the roll front.

Studies of sulfide mineralogy and sulfur isotopes produced equally significant patterns. Sands well downdip in front of the roll front contain predominant amounts of pyrite that is isotopically heavy (greater than zero per mil). Distinct from the pyrite distribution is a later stage of marcasite that is associated with the roll front and occurs as rims around the first-stage sulfides. The sulfur of this ore stage-related sulfide mineralization is isotopically light ( -25 to -40 per mil) and is interpreted to have formed from the pre-ore (first stage) sulfides by a partial oxidation to soluble metastable sulfur oxyanions. Based on the foregoing observations, the authors proposed the following mechanism for the formation of the Benavides deposit: 
(1) Shortly after deposition of the Catahoula sediments, fluids containing dissolved hydrogen sulfide $\left(\mathrm{H}_{2} \mathrm{~S}\right.$ and $\left.\mathrm{HS}^{-}\right)$entered the sandstone aquifer along one of the many growth faults in the region. The most likely fault is approximately $1.5 \mathrm{~km}$ downdip from the deposit, and the hydrogen sulfide-bearing fluids were probably derived from oll and gas accumulations at that depth.

(2) As the fluids moved updip within the aquifer, Fe-Ti oxide minerals were altered to $\mathrm{FeS}_{2}$ (dominantly pyrite). The reducing fluids moved only about $2 \mathrm{~km}$ updip, producing a boundary within the aquifer between the sulfidized (downdip) and unaltered (updip) Fe-Ti oxide-bearing sands.

(3) Oxygenated uraniferous ground waters moved downdip into the $\mathrm{FeS}_{2}$-bearing sandstone and established a roll-type deposit. The partial oxidation of firststage pyrite was followed by the precipitation of marcasite as rims on firststage pyrite in unmineralized sandstones. Although no comparable geochemical studies have been performed on neighboring deposits, it is likely they formed by similar processes.

The deposits in the vicinity of the Webb-Duval county line (Plate $X$ ) are associated with a large area of reduced sandstone that is elongate parallel to the channel sands and associated with faults that cross the channel system. The O'Hern and Longoria deposits are on the southern flank of the area of reduced sands, whereas the Benavides and Holiday-El Mesquite are on the northern flank. The positions of the deposits with respect to this reduced body of sandstone are shown in Figure 25.

The $0^{\prime}$ Hern and Holiday-E1 Mesquite deposits are somewhat unique among orebodies in the Catahoula Formation in that several individual sands are mineralized. The Holiday-E1 Mesquite deposits contain an unusually large accumulation of uranium, probably because all of the sands are in some manner interconnected and are part of the mega-channel system. The remarkable size of this deposit can also be seen in its inordinate length (Plate X) that extends downdip for about 5.5 miles within the same stratigraphic units. Over this distance, its depth below the surface increases from 500 feet to near 1,500 feet.

It appears that the oxygenated ground waters related to the period of ore formation moved down the mega-channel within sands of the Soledad Member, bifurcated, and moved around the central body of reduced sandstone. It is probable that these sands contain abundant pyrite, hence offered strong resistance to oxidation. The roll fronts formed at the boundary between the oxidized and reduced sands. The movement of considerable uraniferous oxidized water tangentially past this interface probably accounts for the size of the deposit. The presence of significant Soledad mineralization downdip from the Holiday-El Mesquite and Longoria orebodies is unlikely. The Soledad Member loses its coarse sand nature and approaches a brackish-to-salt water environment (see Plate XI). Furthermore, the sediments are reported to contain primary oxidation and lack the reduced sands necessary for uranium precipitation.

None of the orebodies within the Catahoula Formation in the South Duval County Mineral Trend show evidence of re-reduction. All the deposits show essentially classical roll-front configurations at the interface between secondarily oxidized and reduced sandstones. 


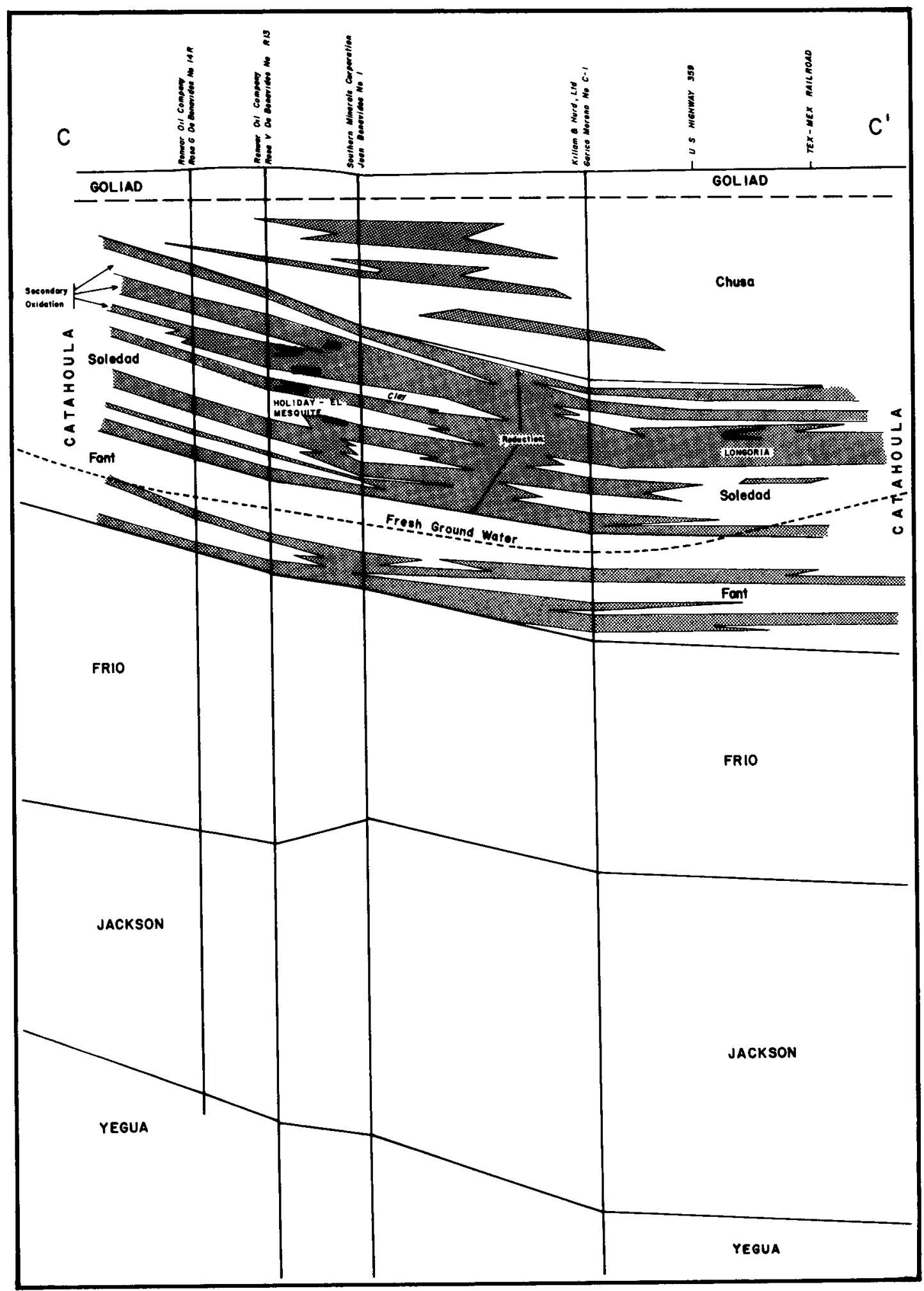

Figure 25. Schematic cross section (C-C') across the South Duval County Mineral Trend. 
East of the Holiday-E1 Mesquite area within the mega-channel system of the South Duval County trend, uranium deposits occur in the basal sands of the Oakville Formation above the Chusa Member of the Catahoula Formation. At least one deposit of economic size has been reported and other significant occurrences of uranium mineralization are known. Plate $X$ shows the location of the McBride, Gurey, and Las Palmas deposits. Figure 26 is a cross section for this area.

These deposits are located near the Crestonia Fault System and occur as roll fronts at the boundary between secondarily oxidized sands to the north and reduced sands to the south. All three deposits occur in the lowest sand of the Oakville, but the sand at Las Palmas is younger in age than the sand at McBride. All the deposits are considered to be part of the same ore-forming solution front. Sands may be up to 50 feet thick and contain mineralization up to 20 feet thick. The deposits are usually small but locally contain high uranium grades. Mineralization is usually confined to the gravels for which measured permeabilities are in the range of 2 to 5 darcies.

The source for the uranium is presumed to be the underlying Chusa Member of the Catahoula, but boulders of trachyandesite reported from the host sand at Las Palmas indicate a volcanic constituent and potential uranium source within the Oakville sands. Volcanic detritus within the Oakville Formation has been reported from other drilling in the area. The mineralization in these deposits is reported to be, at least in part, very young. Disequilibrium factors in a range between 2.5 and 14 in favoring chemical uranium have been reported. This suggests that these deposits may have experienced continuous formation or may be experiencing some rejuvenation due to recent hydrodynamic changes. It is also possible that they are forming at the expense of older orebodies in the underlying Soledad Member.

Plate XI shows an increase in the elevation of the base of the fresh groundwater contact underlying the mineralized area. It has been shown (Galloway et a1, 1979b) that fresh ground water can migrate through aquitards into younger formations. Down hydrologic gradient, within the mega-channel system, ground waters probably move up through the stratigraphic section, particularly where the interconnection of sands and faults permits. As sands in successively younger formations were deposited progressively farther down gradient, many are likely to be in at least limited hydrologic communication (Baker, 1979). Fresh, oxygenated, uranium-bearing ground water may migrate throughout this series until it encounters a reduced host sand. The Las Palmas-McBride area may represent nothing more than the next favorable accessible reduced sandstone downdip from the $0^{\prime}$ Hern-Holiday-El Mesquite area. Mineralization here is found at depths of 300 to 400 feet, the same depths as the updip end of the $0^{\prime}$ Hern and Benavides deposits in the Soledad Member.

Considerable exploration has been conducted east of the Las Palmas deposit at the Tex-Mex and Crestonia occurrences (see Plate X). Mineralization has been reported from depths of 1,200 to 1,400 feet in sands of the basal Oakville Formation. Faulting in this area has evidently been responsible for the introduction of $\mathrm{H}_{2} \mathrm{~S}$ which has reduced the Oakville sands within this area of the South Duval County Mineral Trend. 


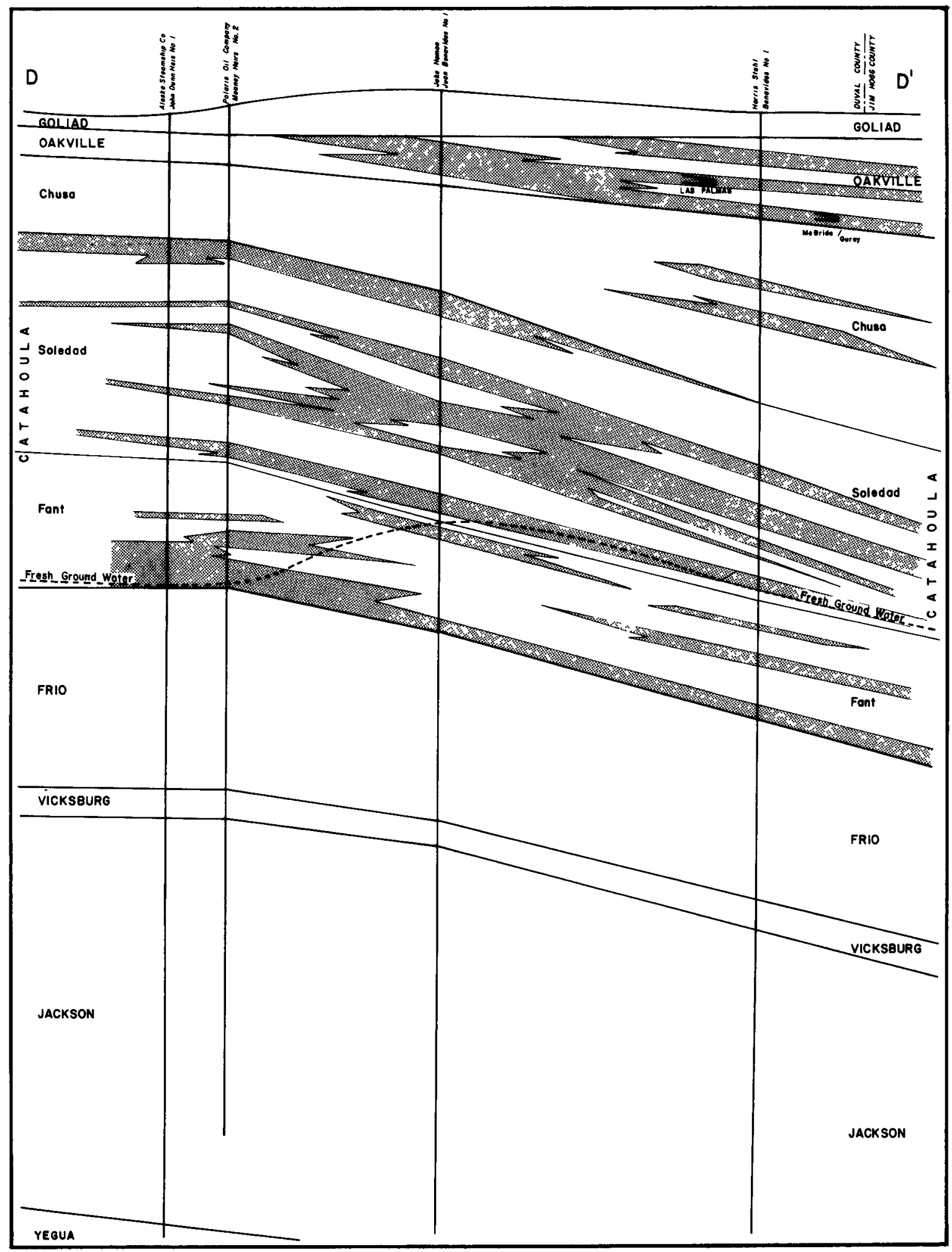

Figure 26. Schematic cross section (D-D') across the South Duval County Mineral Trend. 
Exploration between the Crestonia and Sejita deposits (Plate X) has been scant and no discoveries have been reported. The Sejita deposit occurs on the eastern flank of the Sejita Dome, a salt structure similar to Palangana Dome located about $25 \mathrm{miles}$ to the north. Mineralization occurs as well-defined roll fronts in four or five sands within the Goliad Formation. The area of reduction within the sands is believed to be teardrop shaped and centered over the Sejita Dome, with a tail extending downdip to the east. The secondarily oxidized tongues of sandstone adjacent to rolls are reported to contain limonite that extends west and north along the northern flank of the reduced sands.

Sands of the Goliad are usually well sorted and well rounded but contain moderate amounts of kaolinite. Clear and pinkish quartz, black, brown, and red chert and a few limestone and volcanic fragments comprise the clasts. Sands are usually only 20 to 30 feet thick, and mineralization may nearly occupy the entire thickness. Several high-grade intercepts have been reported (see Fig. 27).

The lack of an obvious source for the uranium in the Goliad deposits partly accounts for the inadequate exploration of the Goliad Formation. The closest source would be the volcaniclastics of the sands or the Catahoula tuffs. Again, as with the deposits in the Soledad Member and the Oakville Formation up the trend, the deposits at Sejita are at depths of 250 to 400 feet. If reduction continues eastward from the Sejita deposit, additional mineralization could be expected in the Gollad Formation at greater depths.

Other mineralization in the Goliad within the South Duval County Mineral Trend has been reported at Alta Verde Dome and Gyp Hill in Brooks County. The known mineralization is not considered economically significant but the area has not been adequately explored.

The South Duval County Mineral Trend represents a single mega-channel sand system that contains more known reserves of uranium than any other trend in South Texas. Whereas all mineralization may not be related to a single mineralizing event, it is apparently related to a single sedimentologic sequence. This sedimentologic sequence is a mega-channel fluvial system that had become established at least by Jackson time and continued to exert control on sedimentation at least through Goliad time. In fact, the present drainage system may be a vestige of this fundamental fluvial system. Where this channel system has been cut by faults, extrinsic $\mathrm{H}_{2} \mathrm{~S}$ has been introduced into various sands of the sediment pile. The base of fresh ground water crosses formational units and maintains a near-horizontal position. This suggests that the oxygenated ground waters introduced throughout geologic time could migrate for considerable distances down the mega-channel system. Uranium in these waters, therefore, would also travel great distances until it encountered one of the local areas of reduced sandstone where it would precipitate in roll fronts. 


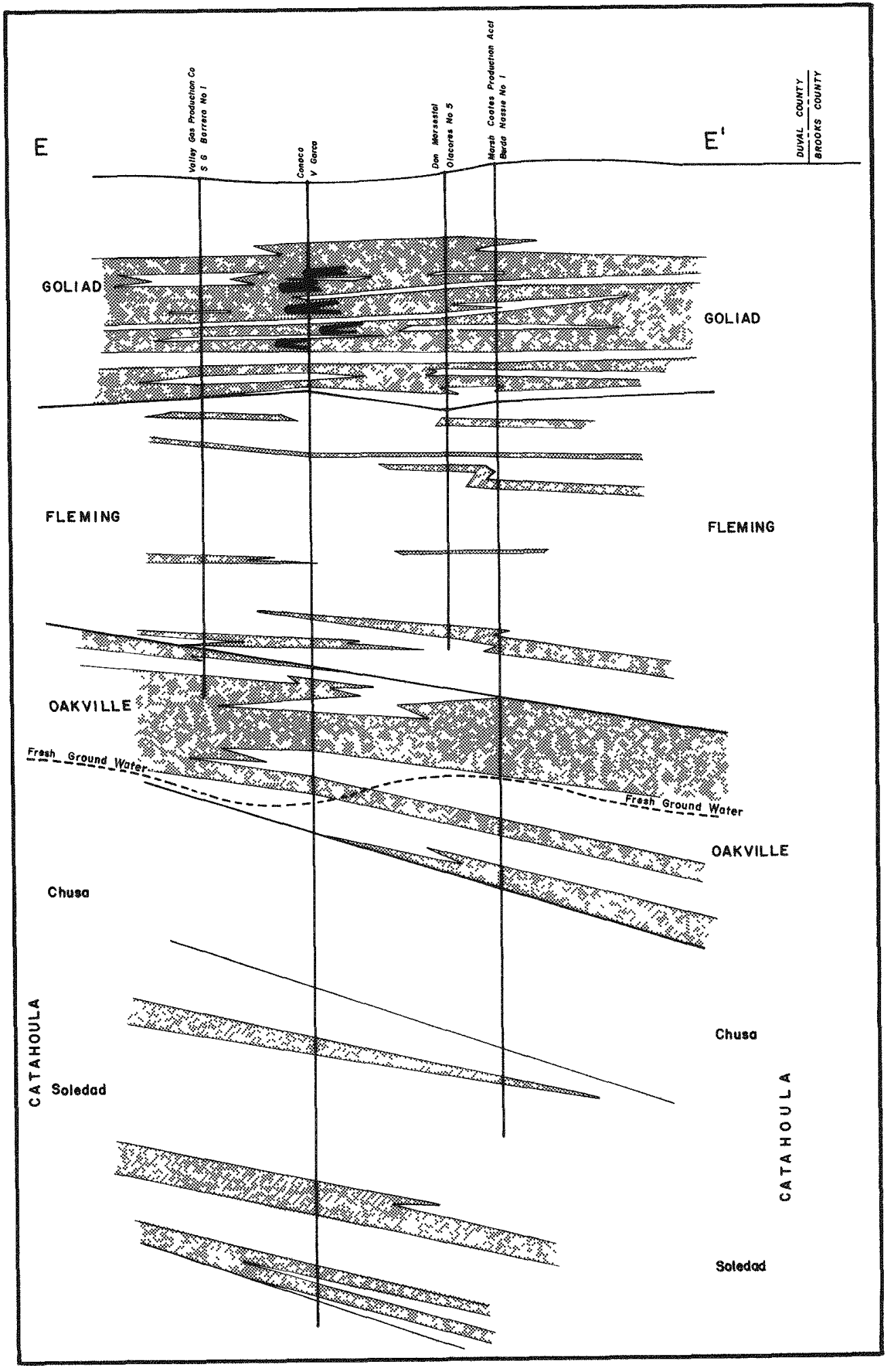

Figure 27. Schematic cross section (E-E') across the South Duval County Mineral Trend. 


\title{
ORIGIN OF THE DEPOSITS
}

\author{
Source of Uranium
}

The source of the uranium in the deposits of South Texas is not known with certainty, but most investigators believe it to have been in the volcanic siltstones and shales of the Catahoula Formation. The restriction of most deposits to sandstones within or immediately above or below the Catahoula, and the association of similar volcaniclastic sediments with all other sandstone uranium deposits, are strong circumstantial evidence that this is correct. The more pertinent observations and comments regarding the source of uranium are briefly reviewed below.

Dickinson (1976b) points to the low uranium content ( $3 \mathrm{ppm}$ ) and the high thorium-uranium ratio (5.6) of the Catahoula Formation as evidence that it has lost considerable uranium. He compares this with the Whitsett Formation of the Jackson Group, which contains an average of $13 \mathrm{ppm} \mathrm{U}_{3} \mathrm{O}_{8}$ and a thorium to uranium ratio of only 2.4 , and concludes that the uranium has not been leached and reconcentrated within this formation. The occurrence of uranium deposits in the Whitsett Formation only where the customarily intervening Frio Formation is absent and the Whitsett and Catahoula are in direct contact suggests that the uranium in those deposits was derived from the Catahoula Formation.

Eargle and Weeks (1973) state that uranium deposits in South Texas are restricted to areas where the host rock contains about 50 percent ash or diagenetically altered ash. They note that the Tertiary igneous rocks in the Big Bend region of western Texas, from which the volcaniclastics of South Texas were presumably derived, contain as much as $45 \mathrm{ppm}$ uranium, which would suggest that the sediments themselves must have had an adequate uranium content to account for the deposits.

Galloway (1977) reports that the average uranium content of 60 samples from the Gueydan fluvial system averages between 2 and $3 \mathrm{ppm} \mathrm{U}_{3} \mathrm{O}_{8}$. He found that the uranium content increased slightly in finer grained sediments but was substantially lower (average less than $1 \mathrm{ppm} \mathrm{U}_{3} \mathrm{O}_{8}$ ) in those sediments which would have experienced leaching and soil formation. By contrast, sediments in lacustrine environments, which presumably would have been protected from early post-depositional leaching, had the highest median uranium contents. Galloway interpreted this to indicate that, as had been suggested earlier by Moxham (1964) and Duex (1971), the Catahoula sediments were strongly leached of their uranium, and the leaching occurred very early after sedimentation. In Galloway's opinion (1977), this is supported by the relations between the uranium contents of the sediments and the inferred extent of syndepositional leaching due to soil-forming processes.

Volcaniclastic material is also an important component of both the Jackson Group and the Oakville Formation (see Sellards et al, 1932, for example). Several authors have suggested that this volcanic material might have provided the uranium for the deposits which occur in the respective sandstones. This is particularly appealing for the 0akville Formation, but there is no compelling evidence that this is the case. As has been pointed out by Dickinson, 
however, the Jackson Group is not known to contain uranium deposits except where it is in juxtaposition with the Catahoula Formation, suggesting that uranium and its deposits were derived not from within but rather from the Catahoula Formation. Any uranium occurrences in older Tertiary sediments, for example the Carrizo Sand, would presumably have to have derived their uranium from interbedded volcaniclastics or possibly the former superposition of the Catahoula or a similarly tuffaceous formation above an angular unconformity.

Host Rocks

Numerous authors have demonstrated that all significant uranium occurrences in the South Texas Uranium Region are associated with permeable sandstones. The larger deposits are generally associated with the more permeable units, although the actual position of mineralization may now be in close proximity to, or in juxtaposition with, finer grained, less permeable sediments. These relations strongly suggest that the deposits owe their origin to ground-water movement through permeable sediment, as has been demonstrated for rol1-type deposits in other regions.

The Texas uranium province is unique among wel1-described rol1-front regions in that the deposits are developed within a complex heterogeneous sedimentologic sequence involving sediments deposited in environments ranging from beach to fluvial. The geometry of the sand bodies and the resulting groundwater regimes are vastly more complicated than those of the braided fluvial systems of the Wyoming basins. The distribution and characteristics of the uranium deposits depend, therefore, on the local sedimentologic conditions and the relations between sediments of diverse depositional environments. Several examples of these relations have been discussed in the text.

Mechanism of Ore Formation

Many of the uranium deposits in the region are known to occur at the downdip margin of tongues of oxidized sandstone in the classical rol1-front association. Some of these deposits have been shown to occur, moreover, in the classical C-shaped form that reflects the direction of ground water flow and propagation of the roll front. The oxidized sands show the typical mineralogic effects of exposure to the oxidizing solutions, in particular the oxidation of pyrite. Other deposits do not display the classic crescentic roll front, but it seems likely from available data that this is due to the presence of interbedded argillaceous material which disrupts the ground water flow and prevents the development of the classical deposit shape. Few deposits have been studied with the same detail as those in Wyoming; hence, basic mineralogic and geochemical data are lacking. Reference has been made to those Texas deposits for which detailed data are available.

Many deposits in South Texas do not occur at the margin of tongues of oxidized sandstone but occur entirely within pyrite-bearing sandstone. Some of these deposits display the classic crescentic shape, suggesting they formed by the roll-front mechanism. It has now been shown that the displacement of these 
deposits from the present boundary of oxidized sandstone is probably due to the introduction of $\mathrm{H}_{2} \mathrm{~S}$ into the host sandstone after ore formation. This $\mathrm{H}_{2} \mathrm{~S}$ combined with ferric iron in the altered interior to form pyrite, thus reducing the sandstone that had been oxidized during ore formation. It seems clear, therefore, that even these once-problematical deposits have formed by the roll-firont mechanism.

Additional evidence in support of the roll-front nature of the South Texas deposits is reflected by element zoning across the deposits. As discussed for several of the individual deposits and as previously summarized by Harshman (Fig. 28), the elements selentum, vanadium, urantum, and molytdenum are zoned across many of the deposits. This zoning, where it has been documented, is similar to that found in Wyoming deposits. Harshman demonstrated that this sequence of elements is precisely that which would result from the movement of oxidizing ground waters into more reducing environments, for example a pyritebearing sand. Figure 29 shows that, for a $\mathrm{pH}$ of 7.5 , an oxidizing solution that becomes increasingly reducing, for example in crossing a roll front, precipitates phases containing selenium, vanadium, uranium, and molybdenum in precisely the order they are found in the deposits. In fact, the $\mathrm{pH}$ may be expected to decrease during ore formation so the path would be toward low $\mathrm{pH}$. Many of the deposits of South Texas differ from rol1-type deposits, however, in their high concentration of ore-stage marcasite.

\section{Mega-Channel Systems}

Fluvial depositional systems were an important environment during the accumulation of all uranium-bearing sediments in the South Texas Uranium Region. The extent of these channel systems varied throughout the Cenozoic Era, at times covering broad areas as during Catahoula and Oakville deposition (Plates VII and VIII), and at other times being restricted to a few trunk channels (see Jackson and Goliad channels, Plates VI and IX). Possible reflections of these systems persist today in the Rio Grande, Nueces, Lavaca, and other rivers that cross the Gulf Coast Plain (Plate XII). Some rivers, such as the Nueces, abandoned their original channels and now enter the ocean in different bays. Until sometime after Goliad deposition, the Nueces crossed central Duval County and emptied into what is now Baffin Bay. Similar changes occurred recently in the San Antonio and Guadalupe Rivers and probably in many of the rivers throughout Tertiary time.

The positions of the fluvial channels in the various formations are not independent of one another but tend to be superimposed and stacked as a succession of younger sand bodies toward the Gulf. These masses of sand are more or less inter-connected and have probably affected growth faulting and ground-water hydrology. These factors, in turn, have controlled the introduction of oxidizing ground waters and $\mathrm{H}_{2} \mathrm{~S}$ into the aquifers, the formation of reduced pyrite-bearing sandstones, and the formation of uranium deposits. Where these conditions interact within a mega-channel system, major uranium deposits and clusters or trends of deposits have been formed.

A compilation and interpretation of published data suggests that the Tertiary coastal plains of South Texas were crossed by approximately 13 mega-channel systems. This interpretation (Plate XIII) is based on comparisons of the 


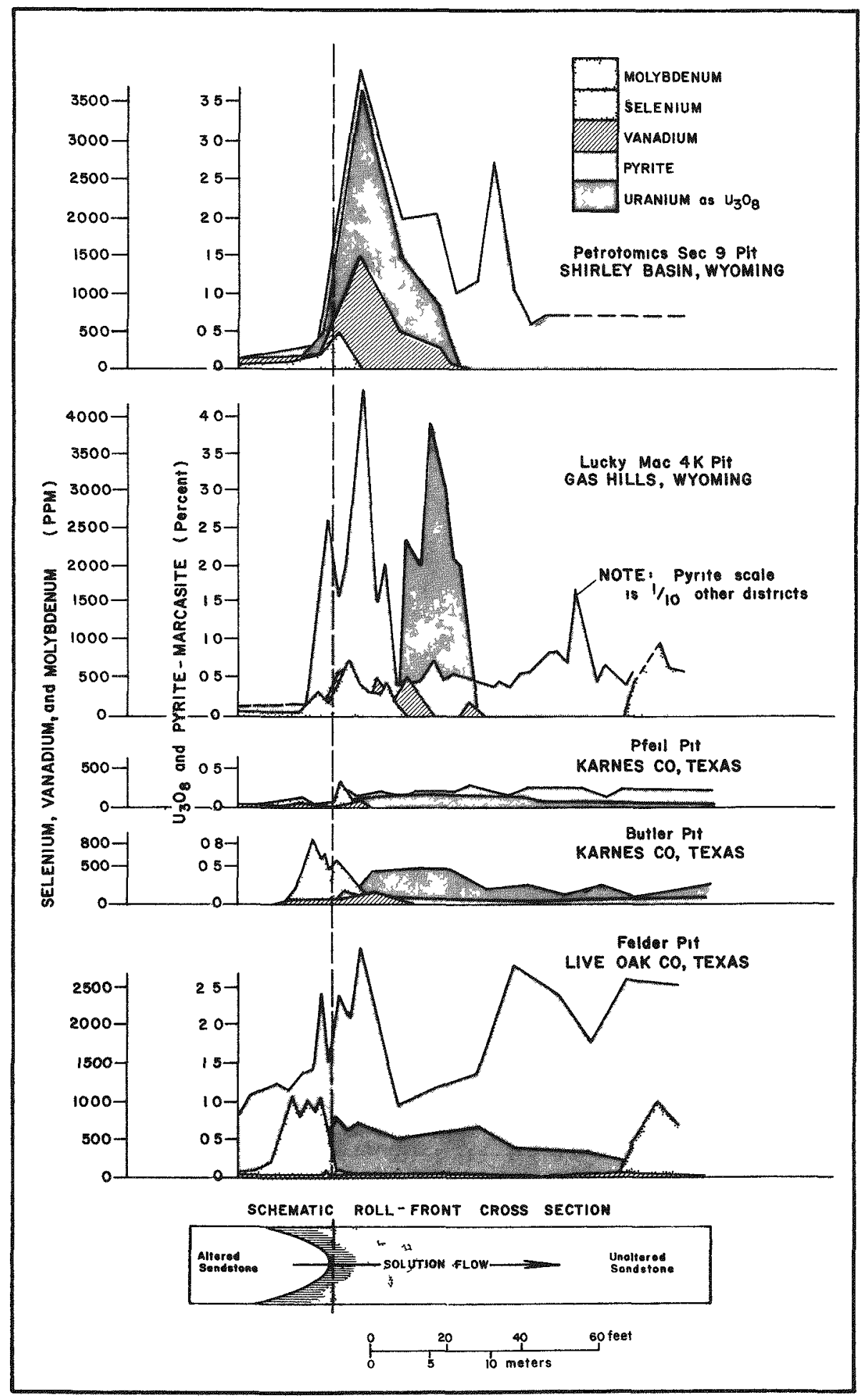

Figure 28. Distribution of molybdenum, selenium, vanadium, pyrite, and uranium in some roll-type deposits (from Harshman, 1974; modified by Harshman and Adams, 1981). 


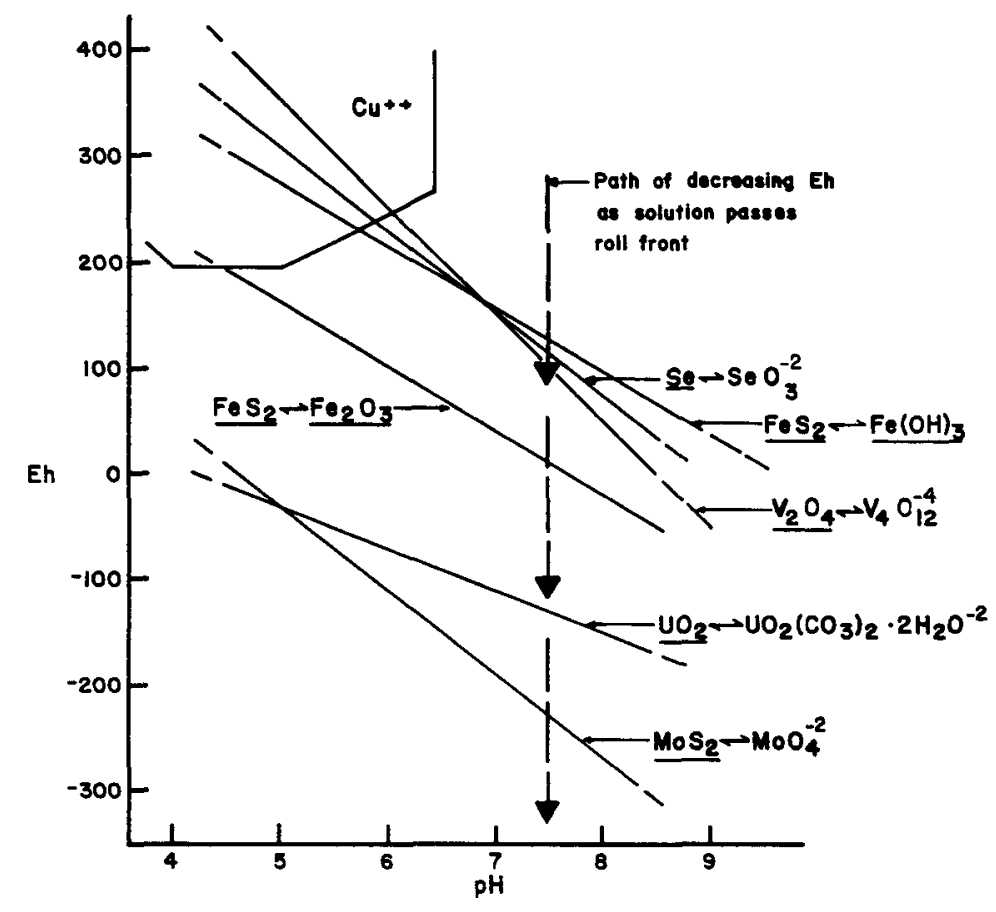

Figure 29. Composite Eh-pH diagram for the principal elements in roll-type uranium deposits and for copper. Solid phases are underlined (from Harshman, 1974; modified by Harshman and Adams, 1981).

channel systems in the Jackson Group and the Catahoula, Oakville, and Gollad Formations and the present river systems (see Plates VI through IX and XII) as presented in the literature. Variations on this interpretation are possible, and, in some cases, well-defined channel boundaries are apparently not present in some formations. The association of ore deposits along some of the better defined channels, however, may encourage the collection of additional data that w11l better define their limits. The possible mega-channel systems have been identified on Plate XIII by geographic location as follows:

East Lavaca County

West Lavaca County

Northwest De Witt County

Southwest De Witt County

Middle Goliad County 
North Bee County

North Live Oak County

South Live Oak County

SoutheasL McMullen County

North Duval County

Middle Duval County

South Duval County

North Starr County

Most of the uranium deposits in South Texas occur within one of these megachannel systems. The notable exceptions are several of the deposits in the Jackson Group that do not occur in continental, fluvial channel sands but rather in sands deposited in beach environments. Even the Jackson deposits, however, appear to be close to a Jackson fluvial channel which probably supplied the oxidizing uraniferous waters to the basal sands. The megachannel systems, therefore, permit the representation of the distribution of uranium deposits in South Texas in a significantly different geometric concept than does the South Texas Mineral Trend shown on Plate I.

The South Duva1 County Mineral Trend has been described to illustrate the occurrence of uranium deposits in successively younger formations along a mega-channel system in a downdip direction. Similar relations can be seen in the North Bee County Mineral Trend where mineralization occurs in Jackson units, possible Frio sands, Catahoula sands, and finally Oakville sands. No Goliad occurrences have yet been reported. The North Live Oak County Mineral Trend has orebodies in the Catahoula, Oakville, and Goliad Formations.

The presentation of the distribution of uranium deposits in South Texas in terms of mega-channels aids in explaining the lack of orebodies in various areas along the South Texas Mineral Trend. Unproductive areas such as westcentra1 Duva1 County or southwest Live Oak County are between mega-channel systems; hence an important component of the ore-forming system is absent.

The area south from the South Duval County Mineral Trend is shown to contain only one mega-channel system, the North Starr County trend. Other megachannels are suspected both north and south of this system, but there are not adequate data to identify their locations. It is known that uranium orebodies occur in Mexico about 30 miles southeast of Rio Grande City in similar fluvial channel systems.

It is obvious from Plate XIII that much of the area of the mega-channel systems, southeast from the South Texas Mineral Trend, does not contain known uranium occurrences. We suspect that this is due largely to the low perceived potential of the Goliad Formation, increased drilling depths to the popular host formations, and the psychological problem of exploring off the historic mineral trend. The updip extent of the mega-channel systems, possibly developed in older Tertiary sediments, has not been investigated. It seems likely that they will continue westward, but their definition will require the analysis of considerable surface and subsurface data. 
The geologic and geochemical characteristics of the South Texas uranium deposits have been discussed in the preceding portion of this report. The origin and controls of the deposits are in general similar to deposits in the major roll-type districts but with important differences that reflect the particular geologic setting of the South Texas Uranium Region. The processes leading to the formation of the deposits, as interpreted from the data presented in this report, are presented briefly below as a working model.

(1) Subsidence in the Gulf Coast region provided a site for the accumulation of more than 50,000 feet of sediments over a prolonged period of sedimentation exceeding $50 \mathrm{~m} . \mathrm{y}$. Acid volcanism, synchronous with part of this subsidence, provided volcaniclastic-rich sediments to a portion of this sedimentary sequence with which all uranium deposits in South Texas are associated. It is uncertain whether basin development and volcanism were related by regional tectonic processes. If so, their juxtaposition can be anticipated in other tectonically similar regions. If not, it might be anticipated that basin sediments without volcaniclastics may be present. Both components are considered to have been essential for the formation of the uranium deposits.

The sediments of the South Texas area were deposited in a complex sedimentologic setting that contained many distinct depositional environments, each with its own characteristics in terms of area, shape, thickness, oxidationreduction characteristics, and the permeability of its resulting sediments. These bodies are now nested in a complex three-dimensional volume of rock which, although orderly and natural in its way, is subject to greater stratigraphic variation and unpredictability than, for example, the braided streams of the Morrison Formation. Similarly, the hydrology of the sediments, which reflects the nature of the sediments and their relations, ranges from simple in the mega-channels to more contorted and complicated in crevasse splays and barrier bars. Available data suggest that the mega-channels are oxidized well beyond the positions of many of the deposits. It is not known whether this oxidation was produced at deposition or formed during early diagenesis as a roll-front phenomenon. This inferred early oxidation does not seem to have been related to ore formation; therefore, it is probably not essential for the formation of major deposits. If it is a post-depositional phenomenon, this oxidation is indicative of high permeability and is, therefore, a useful exploration guide.

(2) Contemporaneous with and early after deposition, the volcanic material within the Catahoula and adjacent Jackson Group and Oakville Formation began to alter and release uranium. Galloway and co-workers have developed evidence to suggest that the effective release of uranium is directly associated with pedogenic processes; hence, it occurred immediately after sedimentation. Sediments escaping these types of soil-forming processes retained much of their uranium.

As the Catahoula Formation continued to accumulate above a slight angular unconformity with the older rock, uraniferous ground waters moved from the Catahoula down into permeable underlying horizons (Fig. 30). Where these horizons contained reductants the oxidized uranium-bearing waters became 
reduced, uranium was precipitated, and roll fronts were formed. The deposits in the carbonaceous-rich beach sands of the Jackson Group are the examples of deposits of this type, and the uranium was probably supplied by dip-oriented fluvial channels which extended from the unconformity down to the beach sand environment. These deposits are similar in structural and 1ithologic settings to the deposits of the Black Hills and Weld County, Colorado, which formed as roll-type deposits in the permeable sediments below an angular unconformity upon which was deposited the tuffaceous White River Formation. With minor exceptions related to the nature of the sediments, the deposits in the Jackson Group, therefore, are similar in terms of ore-forming processes to some of the classical roll-front districts.

The tuffaceous Catahoula Formation was deposited in many different depositional environments characteristic of the South Texas region, in particular, as major fluvial channel systems, crevasse splays, interchannel mud plains, beach, lagoonal and paludal environments, and as marine sediments.

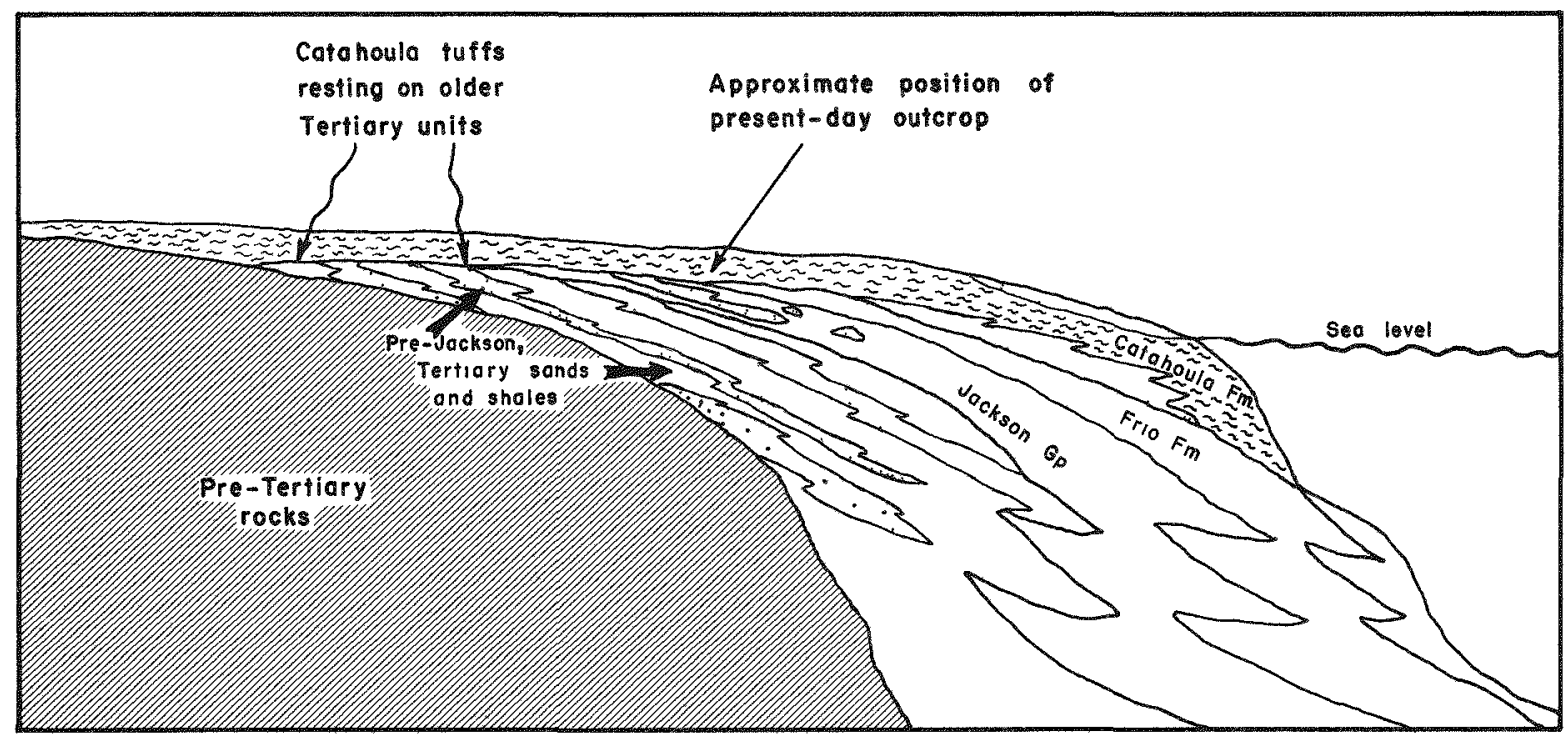

Figure 30. Schematic cross section across the South Texas Central Plain showing the Catahoula Formation resting with angular unconformity on older Tertiary sediments. 
It is uncertain to what extent the important mega-channel systems were oxidized during deposition. With continued sedimentation from Catahoula into Oakville time, many of the sands subsequently involved in ore formation were buried. Ground waters derived from the compaction of adjacent and overlying shales probably moved into these permeable sand systems. This was the period of greatest uranium avallability, and it is likely that all important deposits experienced their initial uranium concentrations during this very early postdepositional period.

(3) Very early after the deposition of the sediments, $\mathrm{H}_{2} \mathrm{~S}$ was introduced locally into the sands of the Catahoula and Oakville Formations. In the virtual absence of carbonaceous material within the ore-bearing sands, this reductant is considered to have been essential for the formation of the deposits. The $\mathrm{H}_{2} \mathrm{~S}$ was apparently introduced into the sands along growth faults that formed contemporaneously with and intermittently after sedimentation. Reduction of the sands may have occurred locally even during sedimentation where the $\mathrm{H}_{2} \mathrm{~S}$ reached the surface and permeated the sandstone adjacent to the structures. The local preservation of carbonaceous trash and highly sulfidic sediments tends to confirm this. The source of some of the pre- and post-ore $\mathrm{H}_{2} \mathrm{~S}$ is believed to have been, on the basis of geologic relation and sulfur isotope data, the Deep Edwards Reef Trend (Goldhaber et a1, 1979). Reynolds et al (1980) found evidence in one deposit for a sulfur source probably within the Tertiary. In the deposits studied thus far (Busche et al, in press), evidence suggests that $\mathrm{H}_{2} \mathrm{~S}$ introduction occurred before and after ore formation but not significantly during ore formation. The map in Figure 31 shows the pertinent geologic relations.

(4) Roll fronts within these two formations, formed by the introduction of uraniferous oxidizing waters into the sulfidized, pyrite-bearingsandstones, account for more than 60 percent of the known uranium of the region. The oreforming process was similar to the formation of roll-type deposits elsewhere, except that pyrite was essentially the only reductant available to establish the oxidation-reduction boundary.

(5) Following ore formation in some of the sands, additional $\mathrm{H}_{2} \mathrm{~S}$ may have been introduced locally into the aquifer, producing the re-reduction of portions of the altered sandstone tongue. Although this arrested ore formation and the propagation of the roll front, oxidizing ground waters may have again moved down the sandstone to form a second roll front at a new updip oxidation-reduction boundary. The propagation of such a younger front might have moved down to and joined the original front, or its progress might have been interrupted by the introduction of more $\mathrm{H}_{2} \mathrm{~S}$. The composite relations in the sandstone after one period of re-reduction and partial re-oxidation are shown in Figure 32.

The timing of these events, the amount of pyrite deposited in the sands, and the rate of ground water flow all affect the mineralogic and geochemical zoning which results, hence the distribution of alteration zones which survive. Although still difficult to prove, it is suspected that all these events that significantly relate to ore formation must have occurred very early in the post-depositional history of the sediments when large amounts of uranium were being released and transported in the aquifers.

(6) The continued movement of oxidizing ground waters, particularly in the mega-channels, probably destroyed some early mineralization in some formations 


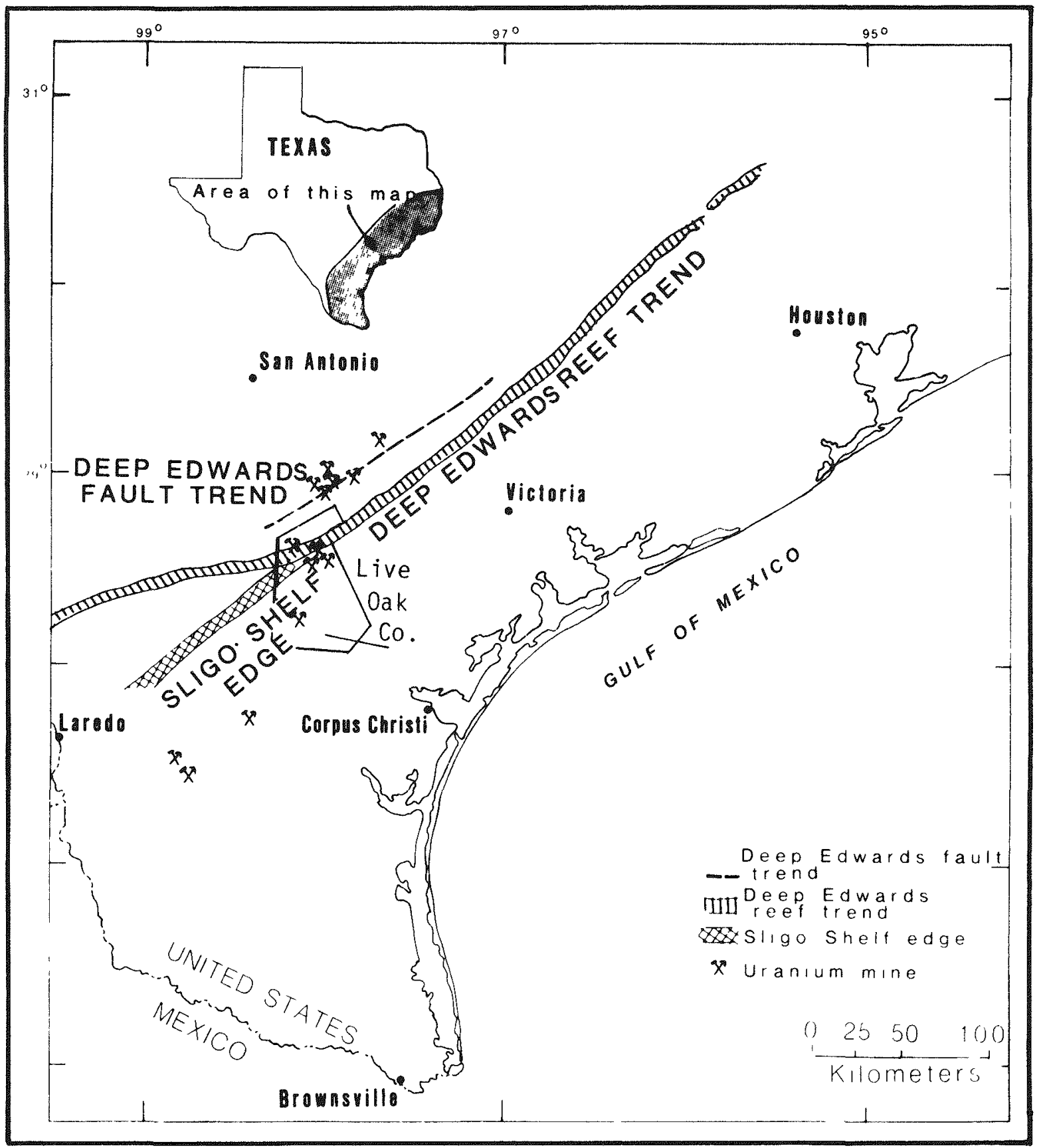

Figure 31. Simplified location map for uranium mines, the surface projection of the Cretaceous Edwards Carbonate Reef Trend and deep Edwards fault trend, and the Cretaceous S1igo shelf edge (modified from Goldhaber et a1, 1979). 
and moved the uranium into younger formations. The apparent presence of oxidized sandstones and uranium mineralization in younger formations (1.e., the Goliad) well down some mega-channel systems suggests that the two are related.

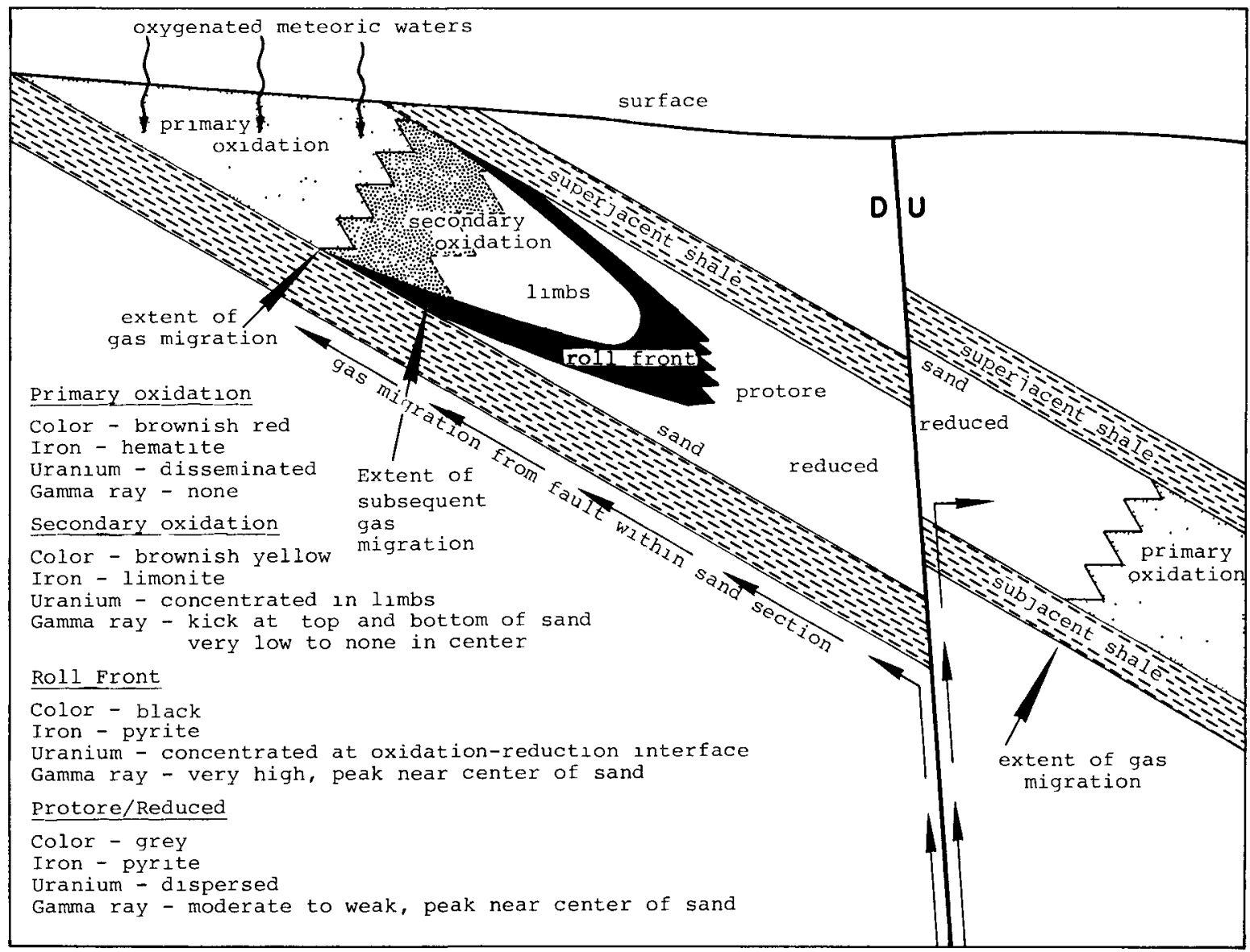

Figure 32. Schematic cross section across a roll front showing relations for secondary reduction and subsequent partial re-oxidation of the altered tongue for a fault-derived sulfide-bearing sandstone. Pathways of earlier $\mathrm{H}_{2} \mathrm{~S}$ introduction are indicated. 
-

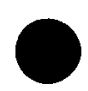




\title{
RECOGNITION CRITERIA
}

\author{
Introduction
}

The available geologic information for the important sandstone uranium deposits in South Texas has been reviewed and discussed in the context of oreforming processes in the preceding sections of this report. We now proceed to identify those geologic characteristics related to these deposits that we feel are most diagnostic for the presence or absence of deposits in unexplored areas. The geologic characteristics selected, including geophysical and geochemical observations, are referred to as recognition criteria and have been shown to be related in some significant way to this type of deposit. These recognition criteria should be useful in resource studies and exploration for estimating the geologic favorability of an area of study for these types of uranium deposits.

The selection, definition, and ranking of recognition criteria are routinely performed by the expert geologist "in his head". The material presented in this section and in the Appendix is not intended for the "expert" but for those geologists involved in exploration or resource studies who are still developing their data bases and interpretations. Nor is this material presented as a "cookbook" to be perfunctorily applied to prospective areas. Considerable geologic judgement is required in the use of the recognition criteria, and inexperienced geologists will encounter much difficulty. The criteria are merely guides to be used by trained geologists as they develop their evaluations of unexplored areas for purposes of exploration or resource studies.

To be useful in resource studies or exploration, recognition criteria are chosen so that: (a) when they are present, or favorable, the chances of a deposit being present are significantly increased, 1.e. they are important "good news"; or (b) when they are absent, or unfavorable, the chances of a deposit being present are significantly decreased, i.e., the negative criteria are important "bad news". Some recognition criteria have both attributes and are thus particularly useful. By using only criteria that significantly affect the likelihood of a deposit being present or absent, one avoids the distraction of including geologic observations which are too ubiquitous or undiagnostic to be useful guides to the favorability of an area.

Considerable subjectivity is involved in the selection, definition, and use of the recognition criteria. Because geologic observations do not lend themselves to rigorous numerical treatment, the use of such data unavoidably involves subjective judgement. In our opinion, it is far better to use the data and the judgements, carefully documenting where and how subjectivity has been used, than simply to leave the reader to make the most of geologic information such as was presented in the preceding sections of this report. In the following paragraphs, therefore, we subjectively select and define those criteria which, based upon our experiences and the data contained in the preceding sections of this report, we consider to be most useful for evaluating areas for the types of deposits that occur in South Texas. We make no pretense that these are the only criteria and definitions that could have been chosen; they are simply the best ones we were able to devise. The reader may 
prefer other criteria and/or other definitions which, if they reflect geologic facts, may improve our 1ist. We acknowledge that such improvements will be needed and solicft constructive comments and contributions. Only through a consensus of careful observations and informed opinions will the criterla become reliable and useful.

Recognition criteria may be defined so that they are general or specific. For example, permeability might be chosen as a criterion and defined to incorporate observations on relevant geologic characteristics, such as sorting, rounding, and sphericity. Conversely, each of these could be chosen as a criterion. For simplicity, we prefer to lump criteria and, therefore, have subdivided them only as far as seems necessary to avoid ambiguity and to identify the most important geologic observations. Here again, subjective judgement and personal preference enter the process.

The detail or scale of each recognition criterion deserves special mention. As exploration and resource studies are conducted on areas of vastly different size and degree of geologic definition, it is appropriate to include recognition criteria that range from regional in scale (1.e., "regional tectonic setting", "uranium content of basement rocks", etc.) to local (i.e., "alteration in the sandstone", "color of interbedded shales", etc.). We have attempted to do this in the accompanying criteria, but some readers may consider certain criteria too general or too detailed to be useful or may wish to include criteria yet more general or more specific. These options, where supported by geologic data, may improve the list of recognition criteria.

In Figure 33, the criteria we have selected for deposits of the South Texas type are arranged by scale of observation, proceeding from the broadest and most regional on the left to the most local on the right. The reader will note that the criteria also are arranged in a hierarchical format, with the more general criteria, located at the top of the diagram, progressively subdivided into more detailed "modifying" criteria toward the bottom of the recognition criteria net. This format, patterned after Hart et al (1978), permits the lowest level criteria (terminal criteria), which are based on field observations, to be combined to evaluate the favorability of the higher level criteria above them. In the evaluation of an area, this combining process continues up through the recognition criteria net until the favorability of the area of study for a South Texas-type deposit is determined. A rigorous method for combining information on the criteria has been presented by Hart et al (1978) and a specific application developed for roll-type deposits by Rackley (Gaschnig, 1980). In the Appendix, we present a much-simplified method for combining geologic observations to reach favorability estimates. The reader is cautioned that the individual criteria are used only to establish the favorability of intermediate level criteria. The ultimate favorability estimate for a South Texas-type deposit is the composite effect of many criteria, and it is not necessarily equivalent to the probability of a deposit being present, as will be discussed in the Appendix.

With recognition criteria identified and organized as in Figure 33 , it is now possible to geologically define each criterion and establish its relative $1 \mathrm{~m}-$ portance in determining the favorability of the criteria above it in the net.

The selection and definition of criteria are subjective, as discussed earlier, but the estimation of the relative importance of criteria is even more so. 
The justification for assigning importance or weight is that intuitively we feel some criteria are more important than others. As with the criteria themselves, we have assigned the best set of welghts we could develop, but they are entirely subjective, and the reader may be justified in modifying our estimates to reflect his data. Weights assigned are obviously only approximations to indicate the relatively encouraging or discouraging nature of a particular definition of a criterion. An estimate of +65 , for example, might as well have been +75 or +50 . We are simply attempting to capture the geologist's approximate estimate of the relative importance of geologic observations as an additional aid in the evaluation of unexplored areas. The system is subjective and imprecise and likely to remain so, but the subjective information is useful if we can learn to collect and use it properly. It is toward that end that the subjective, relative importances are assigned to all criteria in the following section, and a simple method for accumulating this information is presented in the Appendix.

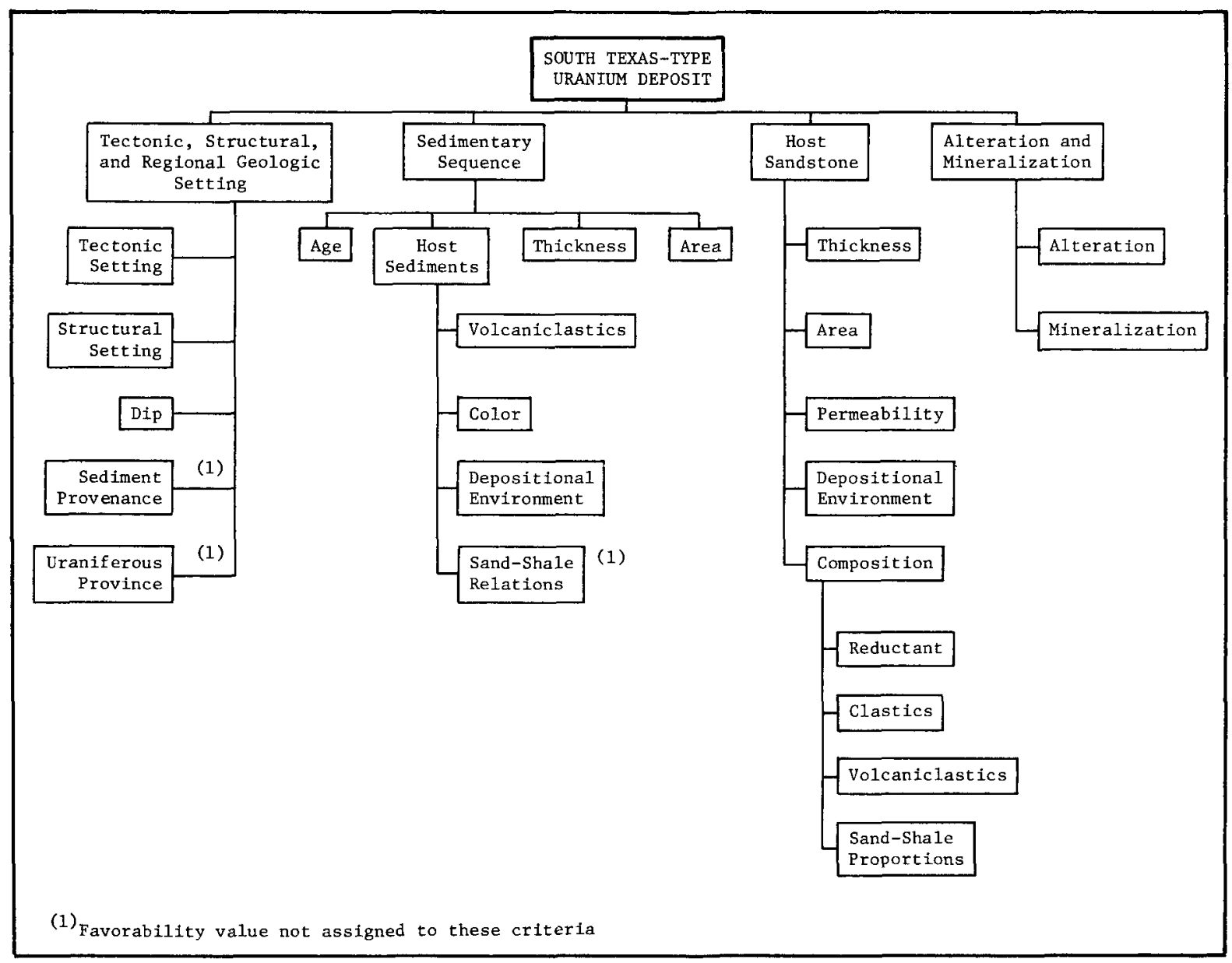

Figure 33. Recognition criteria net for the South Texas-type uranium deposits. 
Evaluation of Recognition Criteria

The assignment of importance or weight to recognition criteria may be conveniently explained by referring to the four criteria in Figure 33 which evaluate the Composition. Each of the four criteria embodies, in the geologist's mind, numerous considerations which relate to geologic observations, the processes they reflect, and their importance to the presence or absence of a uranium deposit. With respect to evaluating Composition, which in turn will be used with four other criteria to evaluate Host Sandstone, these are presumably the four most important criteria that could have been selected, and we assume no important criteria have been omitted.

In most cases, any four such criteria will have different importances in establishing the intermediate criterion above them. Therefore, importance or weight is assigned to each recognition criterion with the aid of the relation shown in Figure 34. Weights are assigned to each criterion independently of the others based on how sufficient the presence of the criterion by itself is for establishing the presence of favorable Composition, or how sufficient the absence of the criterion is by itself to establish the absence of favorable Composition. For example, if one knows about the reductants in the sands in some area under consideration but knows nothing about the three other criteria, how favorable is Composition? The types of reductants one might consider include:

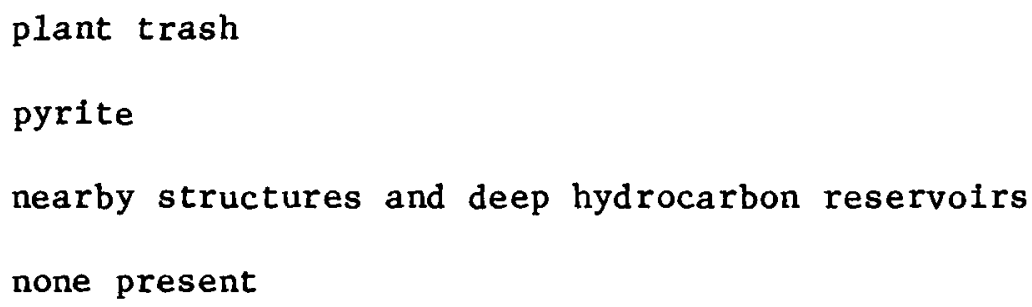

The favorability of Composition decreases from the presence of plant trash in the sands to the total absence of reductants. Other variants on the presence of reductants might have been included, for example, plant trash and pyrite (or more properly its alteration products). No attempt has been made to include examples of all relevant possibilities, merely to provide enough examples so that the geologist can use his judgement in applying the criteria to other geologic conditions. The likelihood of favorable sandstone composition being present is highest if plant trash is present and lowest if no reductants are present in the sands.

Suppose that plant trash is present in the Host Sandstone. Since this is characteristic of sands in which some South Texas-type deposits occur, this is suggestive of "good news" for the presence of the proper sandstone composition, but how suggestive is it? In Figure 34, modifying expressions have been arranged along arbitrary scales from 0 to +100 and 0 to -100 as an aid to the geologist in estimating the importance or weight for a particular criterion. The positive scale is used when geologic observations confirm the presence of a recognition criterion, i.e., it is encouraging or "good news" for the occurrence of the higher level criterion. The negative scale is used when the criterion is absent, i.e., it is discouraging for the presence of favorable composition. Zero is used when the avallable data neither increase nor diminish the favorability of sandstone composition. The scale ranges and 


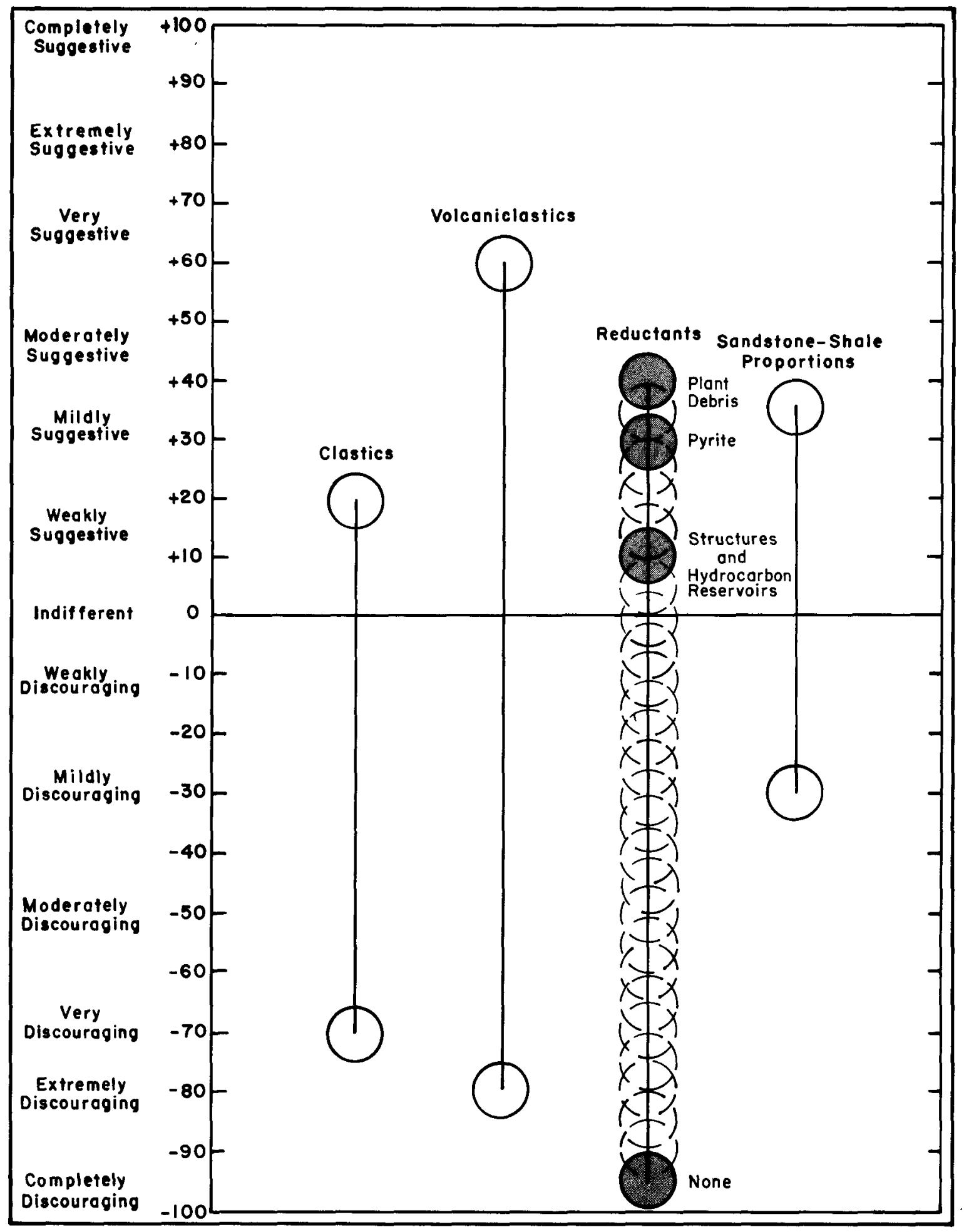

Figure 34. Example of the assignment of weights to recognition criteria using the four criteria that determine Composition for the Host Sandstone. 
modifying expressions might have been chosen quite differently, for example, 0 to 1.0 or 0 to 500 and with different words, such as "favorable" and "very favorable" for the positive scale and "unfavorable" and "extremely unfavorable", etc., for the negative scale. The conventions used were arbitrarily chosen but proved to be suitable for our purposes.

To assign weights to a criterion, the geologist asks, "If the criterion is absolutely perfect, $i . e .$, if in the area under evaluation the sandstone contains plant trash, how suggestive is it that favorable sandstone composition is present?" In the case of composition, we feel the presence of plant trash is moderately suggestive that the composition is perfect, i.e., the criterion by itself is so important that if present with no information on other criteria it provides 40 percent certainty that the composition is perfect.

If, on the other hand, there are no potential reductants present, i.e., plant trash or sulfides, it effectively rules out the possibility of a proper composition, thus we have designated it almost completely insufficient and assigned it a value of -95 . We might have assigned a value of -100 , but out of respect for the vagaries of the earth, we have left some room for surprises. Anyway, the result is essentially the same. The absence of reductants essentially destroys the potential not only for a favorable sandstone composition but also for a uranium deposit. It is up to the geologist using this system to place proper weights on environments not specifically included using his judgement and the examples provided.

Reductants is not the only criterion for evaluating composition. The composition of the clastic grains is also important for the development of proper sandstone composition. When considered without any other information, even perfect clastics are, however, only weakly suggestive $(+20)$ for the presence of favorable composition. If, on the other hand, the clastics are composed dominantly of clasts that can alter and destroy permeability, such as abundant volcanic glass, limestone, mafic lithic clasts, etc., it is considered very discouraging, and we have assigned a value of -70 .

The other two criteria, volcaniclastics and sandstone-shale proportions, have similarly been assigned suggestivity values for when they are present and perfectly favorable and negative values for when they are absent or completely discouraging for the presence of favorable composition. Values have been assigned for all the lowest level criteria and for the intermediate level criteria for evaluating the yet higher level criteria and are tabulated in Table 1. The "model" is now ready to use in the evaluation of real data.

The reader will have perhaps made two observations from the foregoing discussion. First, it is assumed that each recognition criterion is independent of all others, 1.e., each is used separately to evaluate the criterion above 1 . In fact, many criteria are not independently variable and would affect the likelihood of the higher criterion differently in combination than they do by their simple sum. However, error or bias due to non-independence of variables is lost in the accumulated uncertainties of the geologic data and the conclusions we make about them. Second1y, there is a continuous range of decreasing favorability for each criterion starting at the maximum weighting and extendIng down to the most discouraging "worst case". In applying the method, the geologist should use his judgement in selecting favorability values for his field observations. For example, he may believe his area is a miogeosyncline 
but, for some reason, with particular promise for mixed fluvial-shallow marine sediments. He might, for example, assign a value of +50 in contrast to our value of +15 and be justified in doing so. This method is to be used with geologic judgement and good sense and is not a substitute for them.

Table 1. Estimates of the values (scale +100 to -100 ) for the recognition criteria for South Texas-type deposits for establishing the favorability of the criteria above them in the recognition criteria net (see Fig. 33).

\section{$\underline{\text { Criterion }}$}

South Texas-type uranium deposit

$$
\begin{aligned}
& \text { Tectonic, Structural, and } \\
& \text { Regional Geologic Setting } \\
& \text { Sedimentary Sequence } \\
& \text { Host Sandstone }
\end{aligned}
$$

Alteration and Mineralization
Estimate of Suggestivity When Present or Favorable
Estimate of Discouragement When Absent or Unfavorable

Tectonic, Structural, and Regional

Geologic Setting

Tectonic Setting

\begin{tabular}{ll}
$+30 *$ & $-95 *$ \\
$+50 *$ & $-95 *$ \\
$+60 *$ & $-95 *$ \\
$+75 *$ & $-95 *$ \\
+215 & $-\underline{-380}$ \\
\hline
\end{tabular}

Coastal Plain

$+80$

$-95$

Miogeosyncline

$(+80)$

$(+15)$

Eugeosyncline

$(-70)$

Continental Basin

$(-95)$

Structural Setting

$+40$

$-50$

Contemporaneous Growth Faults $(+40)$

Possible Growth Faults

No Growth Faults

$(-50)$

Sediment Dip

$+5$

$-70$

$$
\begin{aligned}
& 0^{\circ}-5^{\circ} \\
& 5^{\circ}-10^{\circ} \\
& 10^{\circ}-20^{\circ} \\
& >20^{\circ}
\end{aligned}
$$

\footnotetext{
*Values assigned to intermediate level criteria.
} 
Sedimentary Sequence

$\begin{array}{ll}\text { Age } & \\ \text { Tertiary } & (+20) \\ \text { Mesozoic } & (+5) \\ \text { Paleozoic } & (0) \\ \text { Proterozoic } & (-70)\end{array}$
Thickness
$>20,000 \mathrm{ft}$
5,000 to $20,000 \mathrm{ft}$
1,000 to $5,000 \mathrm{ft}$
$<1,000$ ft
$(+15)$
$(0)$
$(-30)$
$(-70)$

$+20$

$-70$

$(+5)$

0)

$(-70)$

\section{Area}

$>10,000 \mathrm{mi}^{2}$

1,000 to $10,000 \mathrm{mi}^{2}$

$<1,000 \mathrm{mi}^{2}$

$+15$

$-70$

Host Sediments

Volcaniclastics

Color

Depositional Environment

$+15$

$-50$

$(+15)$

$(0)$

$(-50)$

$$
+70 *
$$

$+120$

$\underline{-285}$

Host Sediments

Volcaniclastics

Abundant

Absent

$(+50)$

$(-95)$
Color
$30 \%-70 \%$ oxidized
$<30 \%$ oxidized

$(+30)$

$(-30)$

$(-50)$

Depositional Environment

Mixed fluvial-shallow marine $(+50)$

Fluvial

$(-40)$

Deep marine

$(-90)$

$+50$

$-95$

$+30$

$-50$

$+50$

$-90$

$$
\text { Deep marine }
$$

$+130$

$-235$

Host Sands tone

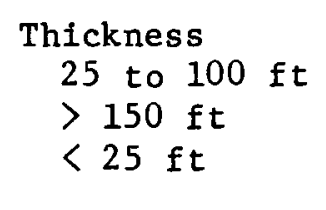
Area
Large
Medium
Sma11

$(+15)$

$(-10)$

$(-60)$

$$
+15
$$

$-60$

*Values assigned to intermediate level criteria. 
Permeability

High

Medium

Low
(+15)

$(-20)$

$(-75)$

Depositional Environment

Abundant fluvial

$(+60)$

Mixed fluvial-shallow marine $(+30)$

No fluvial

$(-50)$

Composition

$+70 *$

$-95 *$

Clastics

Volcaniclastics

Reductants

Sandstone-shale proportions

Composition

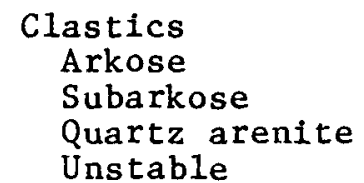

Unstable

$(+20)$

$+60$

$-50$

$(+10)$

$(+5)$

Volcaniclastics

Trace to $15 \%$

None

$>30 \%$

$(-70)$

$+180$

$-330$

$+20$

$-70$

Reductants

Plant trash

Iron sulfides

Structure and hydrocarbon reservoirs

None

$$
+40
$$

$(+40)$

$(+30)$

$(+10)$

$(-95)$

Sand-shale Proportions

$40 \%-60 \%$ sand

$60 \%-75 \%$ sand

$>75 \%$ sand

$<40 \%$. sand

$(+35)$

$(+20)$

$(0)$

$(-30)$

$-30$

$-80$

$+60$

$(0)$

$(-80)$

$$
\begin{array}{r} 
\\
+35 \\
\hline
\end{array}
$$

$+155$

$-275$

Alteration and Mineralization

Alteration

Several types

Some

$(+60)$

$(-10)$

None

$(-80)$

Mineralization

Several anomalies

Some anomalies

$-50$

No a nomalies

$(+80)$

$(+40)$

$(-50)$

*Values assigned to intermediate level criteria. 
In order to apply the recognition criteria net (Fig. 33) to the evaluation of field areas, it now remains to (1) describe the recognition criteria so that they can be evaluated with field geologic observations and (2) assign numerical values to various states of the criteria, depending upon how suggestive or discouraging the states are for the intermediate criterion above them. In the following pages, the criteria are organized by the major second-level criterion shown in Figure 33. The subjective weights for the various criteria, estimated according to procedures described in the preceding paragraphs, accompany the definitions.

\section{Tectonic, Structural, and Regional Geologic Setting}

The South Texas Uranium Region is located within a sedimentary basin on the margin of a continental plate adjacent to a spreading ocean. In addition, the regional geologic setting includes the volcanic field of the Big Bend region and adjacent areas. These simultaneous settings are believed to be critical to the formation of the South Texas Uranium Region; the first as a site for the accumulation of host sediments, roll-front formation, and preservation; the latter as a source for the uranium contained in volcaniclastic sediments and, possibly, ground water. The two components are both essential, although their precise geologic characteristics and relations one to another may differ considerably between field areas. Structures and deformation within the basin are also useful in both broad-scale initial evaluation and in the selection of high-potential areas.

\section{Tectonic Setting}

The tectonic setting strongly affects the accumulation of the sediments, in particular, the thickness, the juxtaposition of depositional environments, the rates of subsidence, and the post-depositional ground water hydrology. A relatively constant rate of subsidence seems to have produced the protracted sedimentation ( 40 to $60 \mathrm{~m} . \mathrm{y}_{.}$) in the Gulf Coast, leading to favorable sedimentologic and structural conditions. In order of decreasing favorability, some possible tectonic settings for the South Texas-type deposits might include:

(1) coastal plain $\quad+\mathbf{+ 8 0}$

(2) mlogeosyncline +15

(3) eugeosyncline $\quad-70$

(4) continental interior basin -95 
Rapid and prolonged sedimentation commonly produces growth faults which reflect compaction and adjustment, particularly in mixed sedimentary environments. The faults are usually tangential or parallel to the basin margins and are both characteristic of the sedimentary environment and probably essential for the formation of many of the deposits in South Texas. If the sediments were widely oxidized during deposition, the faults were probably necessary to the formation of significant deposits. If substantial portions of the sediments were deposited and buried under reducing conditions, deposits could have formed without faulting and the introduction of $\mathrm{H}_{2} \mathrm{~S}$ to form pyrite. If oxidation has occurred, it seems more likely it will be important in the fluvial portion of the mixed depositional environments than in the beach environments. Since the fluvial sediments constitute perhaps two-thirds of the deposits in South Texas, we rank possible structural settings in order of decreasing favorability as follows :

(1) The basin is bounded by numerous parallel or tangential growth faults.

(2) The basin has a limited number of associated faults, some of which may have been active during and after the deposition of the sedimentary sequence.

(3) The basin has no associated faults, or what faults exist are substantially younger than the sediments.

Sediment Dip

Dip during sedimentation is 1 to 2 degrees toward the basin. The dip may be increased to 3 to 5 degrees by deformation related to compaction and the development of growth faults, without disrupting the ground-water hydrology. Steeper dips, either during late diagenesis or subsequent deformation, are considered unfavorable, as they increase the likelihood that deposits were not formed or were destroyed. Estimated ranges in dip are listed below in order of decreasing favorability:

$\begin{array}{lr}\text { (1) } 0 \text { to } 5 \text { degrees } & +5 \\ \text { (2) } 5 \text { to } 10 \text { degrees } & -10 \\ \text { (3) } 10 \text { to } 20 \text { degrees } & -40 \\ \text { (4) Greater than } 20 \text { degrees } & -70\end{array}$

Sediment Provenance

Source rocks yielding coarse, stable clasts such as quartz and feldspar are favorable for the formation of suitable host sandstones. Broad areas of intermediate to acidic, plutonic or granitic rocks, hyperbyssal intrusives and volcanics, and mature coarse clastic sediments are considered favorable. In many cases, the sediment source area may be distant and unknown, and there may even be multiple source areas. For these reasons, we have not assigned favorability values to potential source terrains. 
Evidence suggests that uranium deposits worldwide occur in what have been termed uraniferous provinces. These provinces are characterized by rocks, particularly Precambrian granitic rocks (or the refractory minerals in them such as zircons), acid volcanics, continental clastic sediments, pegmatites, and even metamorphic rocks that contain (a) more than an average concentration of uranium or (b) an abundance of uranium anomalies. In some types of uranium deposits, such as Wyoming roll-type deposits and calcrete deposits, it is generally possible to ldentify the source areas for the sediments. The study of these areas for their uranium contents provides important information on the potential of the sediments in adjacent basins for uranium deposits. In the case of sedimentary environments such as South Texas, it may or may not be possible to infer the sediment source, and the neighboring basement, even if visible, may have little to do with the potential. For this reason, we have not assigned favorability values for uraniferous province.

\section{Sedimentary Sequence}

Uranium deposits of the South Texas type occur in mixed fluvial-shallow marine sedimentary sequences. Favorable sequences contain evidence of contemporaneous sediments ranging from continental fluvial sands to shallow marine muds. The sediments should be thick, deposited under reasonably continuous sedimentation, and with both oxidized and reduced lithologies.

\section{$\underline{\text { Age }}$}

older sediments are less favorable for the presence of uranium deposits because (a) there is a greater likelihood the deposits would have been destroyed during uplifts and changes in ground-water regimes and (b) the amounts of indigenous organic material become less in older sediments, particularly those older than about $2.4 \mathrm{~b} . \mathrm{y}$. An approximate estimate of the favorability of age is as follows:

$\begin{array}{lr}\text { (1) Tertiary } & +20 \\ \text { (2) Mesozoic } & +5 \\ \text { (3) Paleozoic } & 0 \\ \text { (4) Proterozoic } & -70\end{array}$

\section{Thickness}

Thick sedimentary sequences are favorable because (a) the continental margin basins, such as the Gulf Coast, are characterized by thick sedimentary sections and (b) the greater thickness increases the likelihood that conditions suitable for ore formation will occur somewhere within the sediment pile. An approximate measure of the favorability of the thickness might be as follows:

(1) More than 20,000 feet

(2) 5,000 to 20,000 feet 
(3) 1,000 to 5,000 feet -30

(4) Less than 1,000 feet $\quad-70$

Area

As with thickness, favorability increases for large areas covered by the potential sedimentary sequence.

(1) Sediments cover more than 10,000 square miles. +15

(2) Sediments cover 1,000 to 10,000 square miles. 0

(3) Sediments cover less than 1,000 square miles. -50

Host Sediments

Host Sediments refers to a particular part of the Sedimentary Sequence composed of sediments that were deposited in related depositional environments and may include one or more sedimentary members, formations, or even groups. Host Sediments is a more broad and general criterion than, for example, Host Sandstone, which may or may not be known to occur within the Host Sediments. Data on Host Sediments are useful, therefore, in initial regional reconnalssance; whereas data on Host Sandstone will be required in more detailed target evaluation. The Host Sediments will generally be part of a Sedimentary Sequence which either contains uranium deposits or anomalies or is being evaluated for its uranium potential (i.e., the Jackson Group, Catahoula Formation, Oakville Formation, and Goliad Formation in South Texas). As used herein, Host Sediments refers principally to the channel and beach sand bodies and their related shales, lignites, and smaller channel sands. In some settings the requisite sedimentary components, including volcaniclastics and reduced mudstones, may occur in an angular unconformity relation with the potential host sandstone underlying the probable source rock, as is the case for the Jackson Group underlying the Catahoula Formation in South Texas.

The character of the Host Sediments is of critical importance in judging the favorability for South Texas-type uranium deposits. It governs the source of uranium, permeability, distribution of reductants within the unit, position and shape of any mineralized bodies, and their size and grade. Characteristics of both the sandstones and siltstones and their interbedding relations affect the favorability of the Host Sediments and ultimately a Host Sandstone. The abundance, thickness, and character of the mudstones in the Host Sediments provide important information on their likely hydrologic and chemical contributions to the formation of uranium deposits within the associated and interbedded sands.

Volcanic Ash or Bentonite

Volcanic ash, or bentonitic clay derived from the alteration of volcanic ash, is considered to be the most likely source of uranium in the deposits of South Texas. Bentonitic units can generally be recognized by their "popcorn" weathering habit on outcrop. A substantial percentage of volcanic material in mudstones, particularly those in juxtaposition with potential host sandstones, may satisfy the requirement for a uranium source rock in or near the area under investigation. 
Shales and siltstones contain:

(1) Abundant (more than 30 percent) ash or bentonite. $\quad+50$

(2) Volcaniclastics and their alteration products are not present.

Color

Neither entirely oxidized (red) nor entirely reduced (gray, gray-green, buff, etc.) Host Sediments are favorable for the occurrence of uranium deposits in mixed fluvial-shallow marine sediments. Pervasive hematite suggests the sediments were completely oxidized at deposition without subsequent reduction, essentially eliminating the potential for deposits. The absence of any oxidized sediments suggests oxidizing waters have not moved into the sands, hence roll fronts could not have formed. The mixture of oxidized (usually sands) and reduced (usually shales) sediments suggests oxidation and reduction boundaries may be present in the sediments, obviously favorable for roll-type deposits.

The favorability of color may be estimated as follows:

(1) 30 to 70 percent of the sediments are oxidized. +30

(2) Less than 30 percent of the sediments are oxidized. $\quad-30$

(3) More than 70 percent of the sediments are oxidized. $\quad-50$

Depositional Environment

The complex of depositional environments reflected in the sediments is an important characteristic of the South Texas Uranium Region. The presence of depositional environments reflecting fluvial, lagoonal beach, and barrier bar sedimentation is favorable for the occurrence of these deposits, whereas sequences containing dominantly miogeosynclinal or deep-water sediments or braided stream sediments are unfavorable for South Texas-type deposits.

Some possible depositional environments include:

(1) Sediments were deposited in depositional environments characteristic of mixed fluvial-shallow marine sequences. $+50$

(2) Sediments are dominantly fluvial and related continental sediments (i.e., similar to a Wyoming basin which would have low potential for a South Texas-type deposit).

(3) Sediments are dominantly deep marine.

Sand-Shale Relations

Roll-type deposits develop when movement of oxidizing uraniferous ground water is confined to restricted sandstone aquifers by impervious bounding shales or 
siltstones. The interbedding of sand and shale is, therefore, an important criterion. Large orebodies, moreover, form where a large body of water moves across or parallel to an oxidation-reduction boundary, hence within large aquifers. In the fluvial-shallow marine sedimentary sequence, the relations between sand bodies formed in a variety of depositional environments become important. These possible relations are numerous and difficult to appraise in terms of their relative favorability; hence, we have not assigned importance to the relations between sands and shales, but have left the criterion to be covered by Depositional Environment.

Facies relations between sands and shales are also important, particularly those between the source shales and the host sands. It is important that the potential host rock underlies the source rock or be deposited in continuous sedimentary sequence with it. A significant erosional break above the source rock may mean that the uranium released during post-depositional alteration was lost to ground waters before the potential host rock was in place. These sedimentologic relations are typical of mixed fluvial-shallow marine sedimentary sequences; hence, we have assigned no favorability values but leave them to be covered by Depositional Environment.

\section{Host Sandstone}

The Host Sandstone is a specific, potentially favorable sandstone unit or combination of sandstone unlts within the Host Sediments. It has several important and readily identifiable characteristics that are closely related to the source of the sediments and the depositional environment into which it was transported and deposited. Favorable Host Sandstones may be found only in restricted portions of a depositional system and then only locally within a generally favorable area (for example, fluvial sands in the mega-channels, crevasse splays adjacent to them, and beach sands near their terminations). Host Sandstone may be present in several stratigraphic intervals or in several lateral, somewhat parallel belts. If the belts or stratigraphic intervals are sufficiently interconnected, they are perhaps best considered a single Host Sandstone. If not interconnected, they are best considered separate Host Sandstones. Modern hydrostratigraphic nomenclature of ten distinguishes such well-connected aquifers better than conventional stratigraphic names.

\section{Thickness}

The thickness, length, and width of sand bodies are indications of the size of the aquifer, hence its potential for ore formation. These dimensions have different ranges for sand bodies of different types. Uranium deposits of different sizes can form over considerable ranges in these dimensions. As a guide to evaluating areas, we attempt nonetheless to assign ranges in favorability as follows:

(1) 25 to 100 feet in thickness

(2) More than 150 feet in thickness +5

(3) Less than 25 feet in thickness -50 
(1) Host sandstone has a width measured in thousands of feet and the length measured in miles.

$+15$

feet and a length measured in thousands of feet.

(3) Host sandstone has a width measured in tens of feet and a length measured in hundreds of feet.

Permeability

High permeability is essential for the formation of uranium deposits, even though the deposits are commonly not in the most permeable sands but rather in zones where they interfinger with finer grained sediments. Most deposits are associated with medium- to coarse-grained, moderately well sorted sandstone. Host sands may contain considerable clay that formed through the alteration of volcanic clasts, feldspars, and ferruginous silicates. As much of the alteration formed during and after ore formation, such argillaceous sandstone should not necessarily be discouraging. In order of decreasing favorability, sandstones may be classified as follows:

(1) The potential host contains volumetrically significant medium- to coarse-grained, moderately to well

sorted permeable sandstone.

(2) The potential host is a medium- to fine-grained, moderately sorted, somewhat permeable sandstone.

(3) The potential host was deposited as a dominantly poorly sorted, fine-grained sandstone of low permeability (not to be confused with diagenetic clay formed from the alteration of volcanics and other clasts).

\section{Depositional Environment}

Within the mixed fluvial-shallow marine depositional system, potential host sands may be deposited in several restricted environments. Their potential for significant urantum deposits decreases down hydrologic gradient as their size, transmissivity, and access to ground water diminish. The favorability of depositional environments may be represented as follows:

(1) Fluvial sands are well developed and an important part of the mixed fluvial-shallow marine sands in the Host Sediments.

(2) Host Sediments contain some fluvial sands together with delta-plain and shore-facies sands.

(3) Fluvial channel sands are not well developed, and the most prominent sands represent shore facies. 
Four factors related to the composition of the sandstone are considered important in terms of its potential for uranium deposits.

Clastics are considered favorable if they are composed of stable silicates, principally quartz and feldspar, that will resist alteration and preserve permeability. Arkoses are most favorable, because they indicate source rocks which may also have provided the uranium source or even volcaniclastics. Fluvial sands are commonly arkosic to subarkosic. Shore-facies sands, by contrast, may be quartz arenites which, provided they are in hydrologic continuity with fluvial sands, may contain deposits.

Favorability is as follows:

(1) The Host Sandstone is an arkose containing 20 percent or more feldspar.

(2) The Host Sandstone is a subarkose containing 5 to 20 percent feldspar.

(3) The Host Sandstone is composed predominantly of quartz and other non-feldspar clasts.

(4) The Host Sandstone is composed predominantly of unstable clasts such as carbonate, clay, and volcaniclastics.

Volcaniclastics within the sandstone are considered favorable because they suggest that a source for uranium is present within the sediment pile. If information on the Host Sediments is avallable, it will also indicate the likelihood of a source within the sediments; the observation considered here is based on data only for the sandstone. Too much volcanic material is discouraging, as it will likely destroy permeability in the host and prevent the formation of deposits. Favorability may be expressed as follows:

(1) Potential host sandstone contains a trace to 15 percent volcanic clasts. +60

(2) The host sand contains no volcanic clast. 0

(3) The host sand contains more than 30 percent volcanic clasts.

Reductants in the form of detrital plant trash or iron sulfides are essential for ore formation. If plant trash is present, sulfides are unnecessary but may enhance ore formation. In the absence of plant trash, iron sulfides are necessary and will most likely have been formed from introduced $\mathrm{H}_{2} \mathrm{~S}$. The favorability of reductants may be estimated as follows:

(1) The potential host sands contain detrital plant debris. 
(2) The potential host sands do not contain plant debris but do contain reduced zones with iron sulfides in the matrix of the sand.

(3) The oxidation state of the host sands is not we11 known, but they are cut by numerous faults and hydrocarbon reservolrs are present at depth.

(4) No evidence of reductants or reduced sands is known nor are hydrocarbon deposits present at depth.

Sandstone-shale proportions, as reflected by the presence of shale and siltstone interbeds within the host sandstone, are considered favorable because they retard transmissivity and inhibit the flushing of a deposit. Excessive shales, however, may restrict ground water flow, hence prevent the formation of a deposit. The percentage of sand as related to favorability is as follows:

(1) 40 to 60 percent $+35$

(2) 60 to 75 percent $+20$

(3) More than 75 percent

(4) Less than 40 percent

\section{Alteration and Mineralization}

The extent of outcrops and the type of climate will determine if alteration and mineralization are likely to be observed during the early stages of evaluation and exploration. As exploration proceeds, particularly through drilling, differences in host rock characteristics may be noted, and uranium anomalies may be encountered. Uranium anomalies and certain types of alteration are decidedly favorable.

\section{Alteration}

As discussed earlier in this report, favorable types of alteration for the occurrence of roll fronts include sands that contain (a) hematite or limonite (indicating oxidizing ground waters), (b) leached Fe-T1 oxides (whether the sands are oxidized or reduced, indicating strong reduction at some prior time), (c) abundant marcasite (indicating possible roll-front propagation), and (d) partially or completely sulfidized Fe-Ti oxides. The favorability of an area increases with the number of alteration zones recognized. By contrast, it is discouraging to find sands that contain (a) hematite with unaltered or only oxidized Fe-Ti oxides or (b) essentially unaltered Fe-Ti oxides in reduced sands with only minor pyrite. If the sands are known to be essentially all oxidized or all reduced, it is particularly discouraging. Favorability of alteration, therefore, may be summarized as follows:

(1) The potential host contains diverse favorable alteration types. 
(2) The potential host contains minimal favorable alteration types.

(3) The sands do not contain favorable alteration. $\quad-80$

Mineralization

Chemical uranium or radiometric anomalies in the host sandstone, which reflect uranium or its daughter products, are favorable for the presence of deposits. On outcrop, anomalies may be assoclated with small lenses of organic material, clay galls, fossil bones, or the contacts between sands and shales. However, outcrops may show little radioactivity, even updip from large uranium deposits, because uranium is readily leached. In the subsurface, uranium anomalies associated with sand-shale boundaries or high background concentrations in sands or shales as indicated by gamma logs or core assays are encouraging. Arkosic sediments may produce gross gamma radioactivity anomalies due to concentrations of thorium in minerals such as monazite or potassium, principally in potassium clays and feldspars. These anomalies should not be confused with those due to uranium daughter products.

(1) Outcrop and/or limited subsurface data indicate the host contains several anomalies of several times background.

(2) Outcrop and/or subsurface data indicate the potential host sandstone has few anomalies.

(3) Outcrop and/or subsurface data suggest the host sandstone has no anomalies. 
○

0 
Until recently, geologic information on the uranium deposits of Texas was more incomplete than for the other uranium districts in the United States. Not only were the details of the deposits themselves unavailable in the literature, but the geologic setting of the deposits, and even many aspects of the stratigraphy and lithology of the host rocks, had not been well explained. During recent years this has changed dramatically. First, extensive studies of depositional environments along the Texas Gulf Coast have permitted the interpretation of depositional environments within Tertiary sediments of the Coastal Plain. More recently, these studies have provided the basis for investigations of the geologic setting of the deposits, particularly through excellent work at the Texas Bureau of Economic Geology. Finally, some fundamental studies of the mineralogy and geochemistry of certain deposits, conducted by the U.S. Geological Survey, have provided an excellent basis for significantly improving the geologic understanding of this important uranium region.

Although the geologic conditions and processes 1ikely important in ore formation have now been identified, it is important that the successful types of studies be extended to other deposits to test and confirm current hypotheses. It is also important that presumed ore controls be applied to the regional geology in an attempt to improve resource estimates and focus exploration. There are, however, numerous uncertalnties in the working models which could seriously undermine these applications. The more important of these are tabulated below as a note of caution and as an indication of fruftul directions for future geologic studies.

(1) The size, grade, continuity, and geometry of uranium deposits in South Texas are controlled by numerous lithologic and mineralogic factors that reflect, principally, the depositional environment. It should now be possible to categorize in a preliminary fashion the characteristics that might be expected in various geologic settings--for example, fluvial mega-channels with high concentrations of detrital $\mathrm{Fe}-\mathrm{Ti}$ oxides in contrast to well-washed beach sands. Simultaneously, estimates could be made of the relative importance of these environments in terms of economic and potentially economic deposits as reflected in the distribution of past production and present reserves.

(2) Molybdenum is dispersed farther beyond the uranium roll front in some of the Texas deposits, for example the Felder deposit, than is generally characteristic of the deposits formed by the roll-front mechanism. Dispersions such as this, if identified, are useful exploration guides, but it remains to be demonstrated whether this is 11 kely to be a predictable relationship or whether it is unique to those areas in which it has been documented.

(3) Volcanic material contained in the sediments is inferred to have been the source of the uranium in the deposits. Some studies suggest that not all such volcanic material is altered under conditions that released the uranium for ore formation; hence, not all volcaniclastic-bearing sediments would be favorable for ore occurrence. The implications are obviously very important, and studies involving ore microscopy, trace element analyses, thorium:uranium ratios, and other relations should be pursued to establish these relations. 
(4) The mega-channel concept suggests that deposits can be found down hydrologic gradients from fertile, volcanic-bearing sediments, so that the host sands need not contain volcanic material. This hypothesis should be tested wherever subsurface stratigraphic and hydrologic data permit, because the exploration and resource implication could be substantial. Furthermore, whatever additional geologic studies are required to adequately define the location and define the characteristics of the mega-channel system should be conducted.

(5) Oxidation extends well downdip past ore deposits in some sandstones, for example in the South Duval County Mineral Trend. It appears that this reflects the high transmissivity of the fluvial sands in the mega-channel system. This oxidation apparently formed prior to the introduction of $\mathrm{H}_{2} \mathrm{~S}$ and the development of the known rol1-type deposits. It is important to know if this was a depositional oxidaticn or an early post-depositional process with which might be associated ore deposits deeper in the basin.

(6) The importance of growth faults and available $\mathrm{H}_{2} \mathrm{~S}$ for the reduction of oxidized sands has been demonstrated, and some probable sources for the $\mathrm{H}_{2} \mathrm{~S}$ have been identified. It is probably important, however, that the faults were active prior to the time when uranium was being made available to the ground waters. Busche et al (in press) present evidence that $\mathrm{H}_{2} \mathrm{~S}$ was not present during ore formation in the deposits studied. Presumably not all the faults in the Texas Gulf Coast meet this criterion. Regional studies that identify (a) the tectonic setting of known faults and those that could be considered favorable, and (b) viable sources of $\mathrm{H}_{2} \mathrm{~S}$ could identify prospective areas for exploration and resource studies. It has also been suggested (Goldhaber, personal communication, 1980) that faults may transmit organic material from deeper to shallower aquifers where it is used by sulfate-reducing bacteria to produce $\mathrm{H}_{2} \mathrm{~S}$ from $\mathrm{SO}_{4}^{-2}$-bearing ground waters.

(7) The iron content of sediments in which the ore-related reductant is iron sulfide probably influences the character of the deposits. In sediments with low initial iron content in forms such as iron silicates and iron-titanium oxides, the amount of sulfide that can form through the introduction of $\mathrm{H}_{2} \mathrm{~S}$ is presumably low. The resulting low reducing capacity of the sands, therefore, might permit the rapid propagation of a roll front, perhaps even to the distal portion of the permeable sand, without the development of large highgrade deposits. High concentrations of in-place or even introduced iron, by contrast, might permit the development of large high-grade deposits over relatively short transport distances. A better understanding of these relations could permit better estimates of the potential of various sands based upon rather simple petrographic studies.

(8) The regional tectonic relations which produced the Gulf uast sedimentary basin and the volcanic fields of West Texas and adjacent Mexico should be studied to establish whether the proximfty of these two environments is genetically related or coincidental. If the juxtaposition can be predicted in other geologic regions, it will materially assist exploration and resource studies. If not, the favorability of a proper sedimentary sequence, without evidence of source rocks, w111 simply have to be established from 1ithologic studies. 
On the basis of existing data, no deposits have yet been identified, in the United States or elsewhere in the world, that are, in most important respects, analogous to the deposits of South Texas. Although some deposits are reportedly similar, it appears that some of the important geologic characteristics presented under Recognition Criteria are missing. There is no reason why comparable districts should not be present, particularly around continental margins and possibly related to allochogens. Since $\mathrm{H}_{2} \mathrm{~S}-\mathrm{rlch}$ oil and gas occurrences, as sources for $\mathrm{H}_{2} \mathrm{~S}$ and organic material, are essentially prerequisites for a proper South Texas-type environment, it is likely that most areas with potential for South Texas-type deposits would have recelved oll exploration; hence, subsurface data should be available. Such information should be perused for radioactive anomalies and uranium potential. Continental margins adjacent to spreading oceans should be the most favorable exploration regions.

Prospects for the discovery of an entirely new uranium district, comparable to South Texas, in the United States are considered to be only fair to good. Presumably, most o11 and gas logs have been reviewed in at least a cursory fashion and areas with obvious potential pursued. It seems likely, nonetheless, that portions of the Mississippi Embayment, North Slope of Alaska, and perhaps other regions still hold substantial potential. Regional studies, using the recognition criteria described herein, should permit the evaluation of this potential where adequate data exist. A potentially discouraging aspect of such regions might be the long period of subsidence and the deep burial of mineralization should it prove to be present.

South Texas Uranium Region

It is virtually certain that discoveries will continue to be made in a variety of settings within the South Texas region. New deposits will continue to be found along known roll-front systems and as extensions of identified mineral trends. These deposits will generally prove to be comparable to others in the vicinity, in most cases small, and the uranium recoverable only by in situ leaching methods.

Some important discoveries are likely to be made along one or more of the mega-channel systems, particularly where they occur either virtually enclosed in oxidized or reduced ground and have escaped discovery because they do not occur on oxidation-reduction boundaries. If the hosts are sufficiently large aquifers, such as the South Duval County trend, the deposits could be as large or larger than those which have already been discovered. Exploration could be focused by using the various maps and figures presented in the text which help define the distribution of faults, $\mathrm{H}_{2} \mathrm{~S}$ sources in hydrocarbon accumulations and reef zones, and the mega-channel systems. It should be pointed out, however, that all of these data are based on avallable geologic information and presumably could be substantially improved through some original work.

Additional discoveries will undoubtedly be made downdip within the megachannel systems. The most promising targets will be known, productive 
sandstones up through the Goliad, but it is expected that even younger formations may prove to host deposits. Exploration toward the Gulf will, of course, encounter greater depths of the ore occurrence, but potential unquestionably exists.

With the exception of recently reported discoveries in the Carrizo Sand, all discoveries to date have been found in sandstones immediately adjacent to the Catahoula Formation or down hydrologic gradient from its tuffaceous sediments. One might presume, therefore, that hydrologic access to the Catahoula is a requisite for ore occurrence. The presence of deposits within the Jackson Group only where its sands are in continuity with the Catahoula, 1.e., where the intervening Frio is absent, would seem to support this contention. One would conclude, therefore, that the Jackson will be unproductive throughout most of the region. Although this is supported by independent geochemical evidence discussed in the text, this conclusion should be carefully tested so as not to carelessly exclude sands with mineral potential.

Tertiary formations older than the Jackson Group have not yielded uranium production, but deposits are now reported from the Carrizo Sand. Published information suggests that the lithologies, depositional environments, and ground water histories of several formations should have been favorable for ore formation. It is less certain, however, if a proper uranium source was generally available to those hydrologic systems. Bentonite in thin layers has been described from the Queen City Formation, and thin beds of volcanic ash and bentonite also reportedly occur in the Yegua Formation. Even if these occurrences can be verified, it is uncertain whether the material was sufficiently uraniferous and whether it released its uranium in a way that could be accumulated in deposits. The potential of the older Tertiary section should, however, be systematically reviewed, if for no other reason than that it was once probably overlain by the Catahoula from which uraniferous ground waters could have entered these formations and formed uranium deposits at depth. By applying the recognition criteria to field observations in areas of reasonable potential, it is likely that discoveries will continue to be forthcoming. 
ESTIMATION OF GEOLOGIC FAVORABILITY FOR THE OCCURRENCE OF URANIUM DEPOSITS IN MIXED FLUVIAL-SHALLOW MARINE SEDIMENTARY ENVIRONMENTS

\title{
Introduction
}

\begin{abstract}
Numerous methods have been used for estimating the geologic favorability or expected resource endowment of an area for various types of ore deposits (Cargil1 and Clark, 1978; Singer and Ovenshine, 1979; Voelker et al, 1979; Harris and Carrigan, 1980). In this section we present a simplified method for estimating the favorability of an area for the occurrence of South Texastype deposits using the recognition criteria net (Fig. 33) and the weights assigned to the recognition criteria (Table 1). It must be emphasized that the favorability estimate reflects only the general geologic similarities between known deposits, as defined by the recognition criteria, and the geologic characteristics of an area in which similar deposits might occur. A higher degree of geologic similarity yields a higher favorability estimate, suggesting a greater likelihood that the type of deposit for which the recognition criteria were developed is present in the untested area. No attempt is made to estimate the number of deposits or their geologic size, grade, and continuity. These characteristics require information about the known deposits which, in many cases, is not yet avallable.
\end{abstract}

The use of this method presumes that sufficient geologic information is available for the area of study, so that welghts can be confidently assigned to the recognition criteria. In most cases, geologic data are incomplete and values cannot be assigned to all criteria. Using the method described below, the absence of a value for a criterion is analogous to assigning it a value of zero. This could introduce a significant error in the interpretation of the favorability estimate if the geologist fails to note where data were lacking. If the true favorability of the criterion is significantly higher than zero, the absent data lead to a fallaciously low estimate of the area's favorability. This is a common situation, particularly in resource evaluation of Federal lands where adequate geologic information is customarily unavallable for the systematic evaluation for all types of deposits. Geologic favorability simply cannot be estimated until an adequate data base is avallable. Where data are lacking, the large negative and positive welghts indicate those recognition criteria for which data must be acquired. The assignment of a weight of zero may also significantly overestimate favorability if that criterion is in fact very discouraging. There is no substitute for a sufficient data base.

\section{Calculation of Estimated Favorability}

The procedure for calculating an estimated favorability may be conveniently explained by returning to the discussion of Host Sandstone Composition, considered under Evaluation of Recognition Criteria. Weights were assigned to various favorable and unfavorable states of the four criteria that determine 
the favorability of composition. To evaluate the favorability of composition for field areas, favorability values, based on field observations, are assigned to the four criteria. Table 2 presents hypothetical results for four imaginary field areas. In accumulating the values of the recognition criteria, negative and positive values are accumulated separately but in like fashion.

Table 2. Hypothetical recognition criteria values, from four imaginary field areas, for the four criteria that determine Host Sandstone Composition.

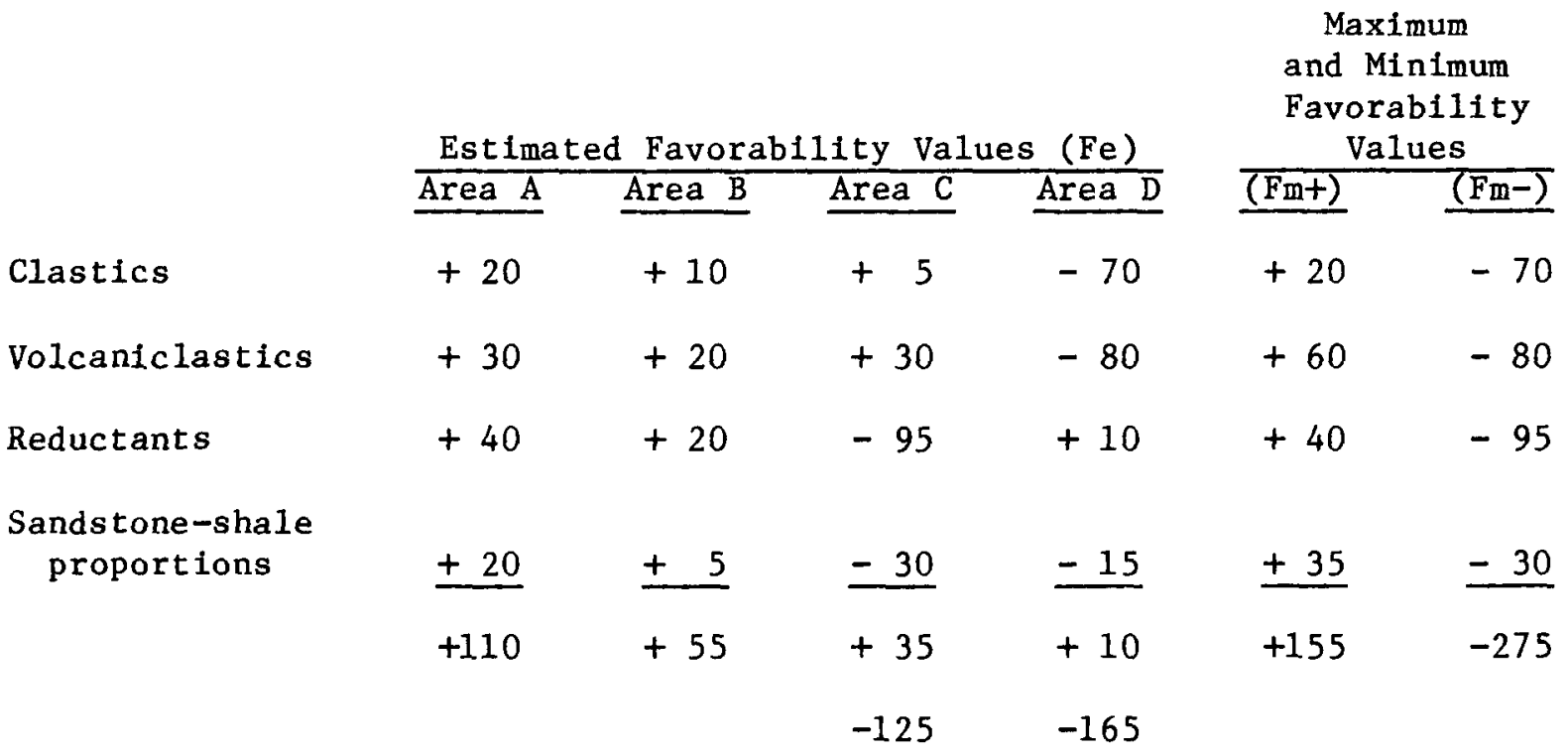

In Test Area A, for example, the clastics have been assigned a value of +20 . Volcaniclastics provides an additional +30 , and so forth for the other two criteria, yielding an estimated favorablitty ( $F e)$ for composition of +110 . However, if all the criteria had been perfect and the maximum favorability values had been used, the sum of the four criteria would have been +155 (Table 2). It is necessary, therefore, to normalize the estimated favorability by dividing it by the maximum favorability ( $\mathrm{Fm}$ ) value to yield a normalized (Fn) value:

$$
\frac{F e}{F m}=\text { or }, \quad \frac{110}{155}=.71
$$

The favorability of composition for Area $A$ is .71, i.e., very suggestive.

For Area $C$, the negative and positive criteria are combined in like manner, but separately, then normalized and summed:

Negative values--

Reductants Sand/Shale Proportions

$-95+(-30) \quad=\quad-125$ 


$$
\frac{F e}{F m^{-}}=F n \quad \text { or, } \quad \frac{-125}{-275}=-.45
$$

Positive values--

$$
\begin{aligned}
& \text { Clastics Volcaniclastics } \\
& +5++30 \quad=\quad+35 \\
& \frac{\mathrm{Fe}}{\mathrm{Fmt}}=\mathrm{Fn} \quad \text { or, } \quad \frac{35}{155}=.23
\end{aligned}
$$

Combining the normalized positive and negative values $(-.45+.23=-.22)$, one determines that Area $C$ has a relatively large negative number, hence, a discouraging composition. This is not a very favorable area in which to prospect for a South Texas-type deposit. In fact, the large negative values for reductants would be sufficient in most geologists' minds to kill the potential of this area. The explorationist should thus not waste further time in collecting other detalled geologic information from this area. This example shows that the geologist making the evaluation must always inspect individual negative numbers, which, if sufficiently discouraging, can destroy the entire potential for the area, even though the accumulation of numerous positive observations may yield a net positive answer.

It can be seen in Figure 33 and Table 1 that composition is merely one of five criteria that define the favorability of the Host Sandstone. From Table 1 it will be seen that composition can contribute a maximum of 70 points; hence, in our example for Area A, composition becomes:

\section{$0.71 \times 70=50=$ Applied Normalized Favorability（Fna）}

This value can now be used with the values for the four other intermediate criteria in calculating the value of the higher order criterion, namely, the favorability of Host Sandstone. In a similar manner, all other terminal criteria are combined to evaluate intermediate criteria until the favorability for a South Texas-type deposit has been evaluated. This favorability is not necessarily equivalent to the probability of a deposit being present, as is discussed in a later paragraph.

\section{Completeness and Confidence of Geologic Data}

Assuming that the field geologist has complete geologic data and is equally and completely confident about all his field observations, he may evaluate the favorability according to the preceding paragraphs. In most cases, however, he will lack data and probably have various levels of confidence regarding the data that do exist. His confidence for different observations may range from completely certain that, for example, a uranium source rock is present, to no confidence (i.e., he does not know) that the age of the prospective basin sediments is Eocene. In such circumstances, methods can be devised to modify the favorability estimates, but no calculations can overcome the lack of data or confident observation. Such shortcomings must be carefully documented and the resulting favorability estimate interpreted accordingly. 
Favorability estimates prepared by the methods described in the preceding paragraphs should be accepted and used only after review of four important parameters:

(1) The final favorability estimate itself;

(2) Favorability estimates for intermediate level criteria;

(3) Favorability values for individual criteria, particularly large negative values; and

(4) Completeness of data and certainty of observations.

Each of these is briefly discussed, with reference to favorability estimates made for three areas in the United States, and presented in the next section.

The final favorability estimate reflects the net geologic favorability of an area when compared with the type area (i.e., the South Texas Coastal Plain) for which the recognition criteria net and maximum and minimum favorability values were selected. A score of 100 indicates a perfect geologic fit, i.e., virtual assurance that at least one deposit is present. A final score of zero indicates a very low level of favorability, provided the geologic data were complete, and the prospects of finding a deposit would be comparable to hitting a deposit with a dart thrown at a map of North America. A favorability of +50 , therefore, is only half as favorable as one of +100 . If the score is based on high confidence in the observations and complete data (i.e., no zeros assigned to criteria because of unavailable data), the area may be said to possess only half the favorable attributes necessary for a deposit. This does not mean the area has a fifty percent chance of a deposit being present. In our fudgement, the likelihood is less, but how much less is difficult to estimate. At a favorability estimate of zero, the chances of a deposit being present are vanishingly small, and at negative favorabilities the chances are even worse. Figure 35 is our subjective attempt to relate estimated favorability of an area to the chances of a deposit being present within that area. The relationship suggests that the chances of a deposit being present decrease more rapidly than the estimated favorability. At 75 percent favorability, for example, we feel there is about a 50 percent chance that a deposit is present.

The estimated favorability values for the second-level criteria of the recognition criteria net (Fig. 33) for the three areas considered in the next section are also useful for interpreting the favorability estimates. Inspection of these values, which are tabulated below, permits one to determine the contribution of each intermediate level criterion to the final estimated favorability. 


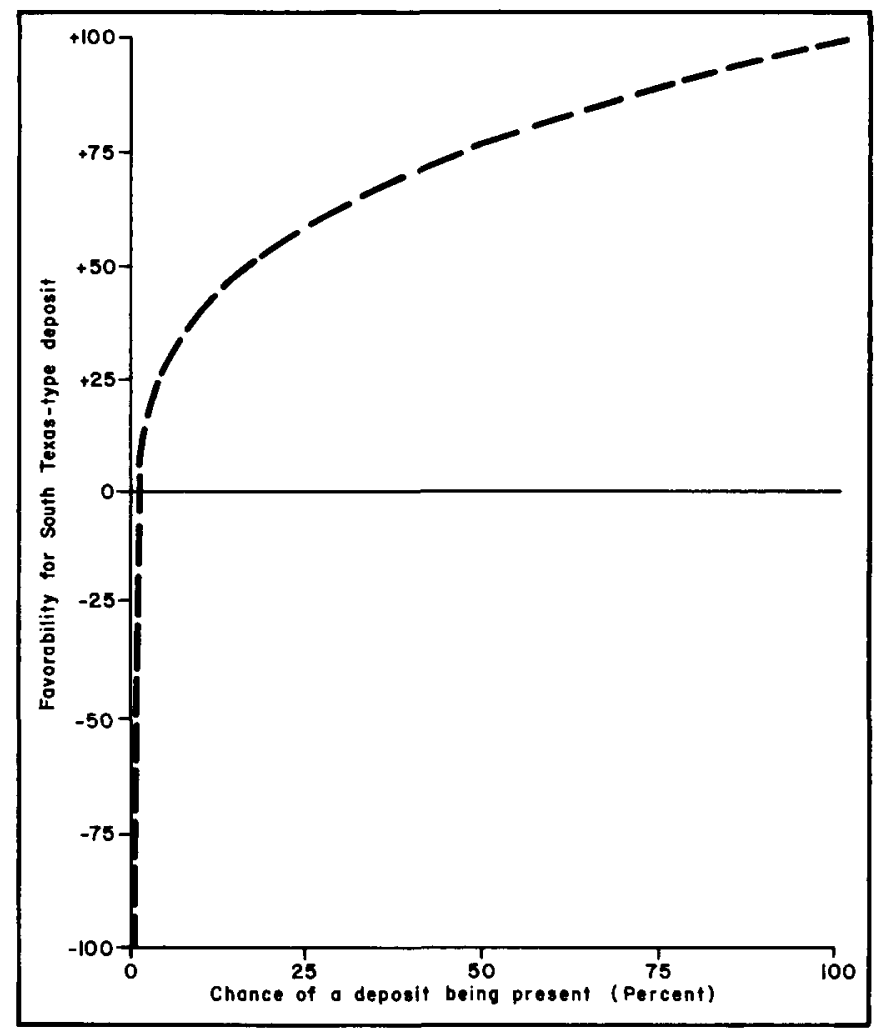

Figure 35. Schematic relation between calculated favorability for South Texas-type deposits and the chances of a deposit being present within the area evaluated. 
Second-Level Criterion

Tectonic, Structural, and

Regional Geologic Setting

Sedimentary Sequence

Host Sands tone

Alteration and Mineralization
Applied Normalized

Favorability Values

\begin{tabular}{|c|c|c|c|}
\hline South & Southern & & Applied \\
\hline $\begin{array}{l}\text { Duval } \\
\text { County }\end{array}$ & $\begin{array}{l}\text { Black } \\
\text { Hills }\end{array}$ & $\begin{array}{l}\text { Houston } \\
\text { Embayment }\end{array}$ & $\begin{array}{l}\text { Normalized } \\
\text { Values }\left(F_{m}+\right)\end{array}$ \\
\hline
\end{tabular}

30

0

25

30

44

0

31

50

57

29

48

60

75

31

54

75

The favorability of the Southern Black Hills (SBH) is substantially less than South Duval County (SDC) because it is inferred to occur in a different tectonic setting and has a different sedimentary sequence than occurs in South Texas. The favorability of the Houston Embayment (HE) is slightly low for all the second-level criteria. By similar comparisons, one can pursue favorability values down through lower levels of the criteria net and ascertain exactly where favorable and unfavorable observations are originating.

Strongly negative values for individual criteria are, in some cases, sufficient to essentially kill the potential of an area. In the final favorability estimate, a single large negative value may become lost in generally positive criteria values; hence, the geologist must inspect the values of individual criteria.

Finally, the completeness of the data, hence the number of zero values, may produce erroneous estimated favorability values. In exploration, low favorability values due to incomplete and uncertain data are not as unfavorable as low favorabllity values resulting from negative or low positive criteria values. In resource studies, however, the absence of data could yield an apparent favorability much lower (or higher) than the area warrants. Careful inspection must be made of incomplete and uncertain data and the resulting favorability estimate interpreted accordingly. Where new data or more certain observations are needed, the criteria weights will indicate which observations are most important to obtain. 
In the following pages, recognition criteria are used to estimate the geologic favorability for South Texas-type deposits in two areas in Texas and one in a Mesozoic marginal marine sedimentary sequence in South Dakota. These examples are chosen to illustrate one simple method for developing favorability estimates.

The following abbreviations are used throughout:

$$
\begin{aligned}
& \mathrm{SDC}=\text { South Duval County, Texas } \\
& \mathrm{SBH}=\text { Southern Black Hills, South Dakota } \\
& \mathrm{HE}=\text { Houston Embayment, Texas } \\
& \mathrm{Fe}=\text { Estimated favorability value } \\
& \mathrm{Fm} \quad=\text { Maximum favorability value } \\
& \mathrm{Fn} \quad=\text { Normalized favorability value } \\
& \text { Fna }=\text { Normalized applied favorability value }
\end{aligned}
$$

Estimated Favorability (Fe) is simply the sum of the favorability values assigned to each of a group of criteria that determines the favorability of a higher intermediate level criterion, based upon field data.

Maximum Favorability $(F m)$ is the sum of the maximum values that could be assigned to those criteria.

Normalized Favorability (Fn) is equal to the estimated favorability divided by the maximum favorability. It may be interpreted, therefore, as a percentage of the total possible favorability of the criteria.

Normalized Applied Favorability (Fna) is the normalized favorability of a group of criteria which is then multiplied by the weight assigned to the criterion above; the product is the weight for that higher level criterion that is then used with other criteria to calculate the favorability of the next higher level criterion. For example (Fig. 33), four criteria determine the favorability of Composition. The normalized favorability obtained from these four criteria is not used directly in combination with the five other criteria that establish the favorability of Host Sandstone but is multiplied by the positive or negative value $(+70,-95)$ assigned to Composition (see Table 1). It is necessary to calculate Fna only where higher level criteria have been assigned separate weight values, generally toward the top of the criteria net, and all such assigned weights are indicated by asterisks in Table 1 .

I. Tectonic, Structura1, and Reglonal Geologic Setting (TSRS)

The favorability of TSRS is determined by the geology of three criteria: 
(a) Tectonic Setting

$$
\begin{array}{lll}
\mathrm{SDC} & +80 & \text { (coastal plain) } \\
\mathrm{SBH} & +10 & \text { (marginal marine sediments) } \\
\mathrm{HE} & +60 & \text { (near perfect score) }
\end{array}
$$

(b) Structural Setting

$$
\begin{aligned}
& \text { SDC }+40 \text { (perfect score) } \\
& \text { SBH }-5 \text { (unfavorable structures) } \\
& \mathrm{HE} \quad+40 \text { (perfect score) }
\end{aligned}
$$

(c) Sediment Dip

$$
\begin{aligned}
& \mathrm{SDC}+5\left(0-5^{\circ}\right) \\
& \mathrm{SBH}-10\left(5-10^{\circ}\right) \\
& \mathrm{HE}+5\left(0-5^{\circ}\right)
\end{aligned}
$$

(d) TSRS Score

The favorability estimate (Fe) for TSRS is the sum of the individual favorability numbers derived from field data:

$$
\begin{aligned}
& \mathrm{Fe} \mathrm{SDC}=80+40+5=+125 \\
& \text { Fe SBH }=\begin{array}{l}
\text { Pos }+10=+10 \\
\text { Neg }-5+(-10)=-15
\end{array} \\
& \text { Fe HE }=60+40+5=+105
\end{aligned}
$$

Reference to Table 1 shows that the maximum and minimum favorabilities for TSRS that could be derived from the sum of these criteria are:

$$
\begin{aligned}
& \mathrm{Fm}_{+}=80+40+5=+125 \\
& \mathrm{Fm}-=-95-50-70=-215
\end{aligned}
$$

We now want to know the extent to which the estimated favorabilities achieved the maximum and minimum potential favorabilities; hence, we divide the estimate ( $\mathrm{Fe}$ ) by the appropriate maximum ( $\mathrm{Fm}+$ ) and minimum ( $\mathrm{Fm}-$ ) values. One also notes (Table 1) that the maxlmum values of TSRS for evaluating the favorability for a South Texas-type deposit are +30 and -95 . We can, therefore, combine two steps and calculate directly the normalized applied favorability which is the contribution to the favorability for a South Texas-type deposit:

$$
\mathrm{Fna}=\frac{\mathrm{Fe}}{\mathrm{Fm}} \times 30 \text {, }
$$


thus,

$$
\begin{aligned}
& \text { Fna SDC }=\frac{125}{125} \times 30=+30 \text { (a perfect score) } \\
& \text { Fna SBH Pos }=\frac{10}{125}=+.08 \\
& \text { Fna SBH Neg }=\frac{15}{215}=-.07 \\
& \text { Fna SBH Net }=+.08-.07=+.01 \\
& \text { Fna SBH }=+.01 \times 30=0 \text { (rounded from } \cdot 3) \\
& \text { Fna HE }=\frac{105}{125} \times 30=+25 \text { (near perfect score) }
\end{aligned}
$$

II. Sedimentary Sequence
(a) Age
$\mathrm{SDC}=+20$ (Tertiary)
$\mathrm{SBH}=0$ (Paleozoic)
$\mathrm{HE}=+15$ (Tertiary)

(b) Thickness

$$
\begin{aligned}
& \operatorname{SDC}=+15 \text { (over 20,000 feet) } \\
& \mathrm{SBH}=-30 \quad(1,000 \text { to } 5,000 \text { feet }) \\
& \mathrm{HE}=+15 \text { (over } 20,000 \text { feet) } \\
& \mathrm{SDC}=0 \quad(1,000 \text { to } 10,000 \text { square miles }) \\
& \mathrm{SBH}=0 \quad \text { (as above) } \\
& \mathrm{HE}=+15 \text { (more than 10,000 square miles) }
\end{aligned}
$$

(c) Area

(d) Host Sediments

(1) Volcanic ash or bentonite

$$
\begin{array}{ll}
\mathrm{SDC}=+50 & \text { (a perfect score) } \\
\mathrm{SBH}=-95 & \text { (none in sediments) } \\
\mathrm{HE}=+20 & \text { (some present) }
\end{array}
$$


(2) Color

$$
\begin{aligned}
& \mathrm{SDC}=+30 \text { (favorable oxidation-reduction) } \\
& \mathrm{SBH}=+30 \text { (as above) } \\
& \mathrm{HE}=-30 \text { (insufficient oxidation) }
\end{aligned}
$$

(3) Depositiona1 Environment

$$
\begin{aligned}
& \mathrm{SDC}=+50 \text { (mixed fluvial-marine) } \\
& \mathrm{SBH}=+50 \text { (as above) } \\
& \mathrm{HE}=+50 \text { (as above) }
\end{aligned}
$$

(4) Host Sediment Score

$$
\begin{aligned}
\mathrm{Fe} \mathrm{SDC}= & 50+30+50=+130 \\
\mathrm{Fe} \mathrm{SBH}= & \text { Pos } 30+50=+80 \\
& \text { Neg }-95=-95 \\
\mathrm{Fe} \mathrm{HE} & \text { Pos } 20+50=+70 \\
& \text { Neg }-30=-30
\end{aligned}
$$

The assigned weights for Host Sediment are +70 and -95 (Table 1); hence:

$$
\begin{aligned}
& \text { Fna SDC }=\frac{130}{130} \times 70=+70 \text { (a perfect score) } \\
& \text { Fna SBH Pos }=\frac{80}{130}=+.62 \\
& \text { Fna SBH Neg }=\frac{-95}{235}=-.40 \\
& \text { Fna SBH Net }=+.62-.40=+.22 \\
& \text { Fna SBH }=+.22 \times 70=+15 \text { (out of possible }+70) \\
& \text { Fna HE Pos }=\frac{70}{130}=+.54
\end{aligned}
$$


Fna HE Neg $=\frac{-30}{235}=-.13$

Fna HE Net $=+.54-.13=+.41$

Fna HE $=.41 \times 70=+29$ (out of possible +70 )

(e) Sedimentary Sequence Score

$$
\begin{aligned}
& \mathrm{Fe} \mathrm{SDC}=+20+15+0+70=+105 \\
& \mathrm{Fe} \mathrm{SBH}=\text { Pos } 0+0+15=+15 \\
& \text { Neg }-30 \quad=\quad-30 \\
& \mathrm{Fe} \mathrm{HE}=+15+15+15+29=+74 \\
& \text { Fna SDC }=\frac{105}{120} \times 50=+44 \text { (out of a possible }+50 \text { ) } \\
& \text { Fna } \mathrm{SBH} \text { Pos }=\frac{15}{120}=+.12 \\
& \text { Fna SBH Neg }=\frac{-30}{285}=-.11 \\
& \text { Fna } \mathrm{SBH} \text { Net }=+.12-.11=0 \text { (rounded from }+.01 \text { ) } \\
& \text { Fna } \mathrm{SBH}=0 \times 50=0 \text { (out of a possible }+50 \text { ) } \\
& \text { Fna HE } \quad=\frac{74}{120} \times 50=+31 \text { (out of a possible }+50 \text { ) }
\end{aligned}
$$

\section{Host Sandstone}
(a) Thickness
SDC +20 (25 to 100 feet thick)
$\mathrm{SBH}+20$ (as above)
$\mathrm{HE}+20$ (as above) 
(b) Area

SDC +15 (a major sedimentary unit)

$\mathrm{SBH}+15$ (as above)

$\mathrm{HE}+15$ (as above)

(c) Permeability

SDC +15 (very permeable)

SBH -20 (some permeability)

$\mathrm{HE}+15$ (very permeable)

(d) Depositional Environment

SDC +60 (we11-developed fluvial sands)

SBH +30 (some fluvial sands)

$\mathrm{HE}+60$ (well-developed fluvial sands)

(e) Composition

(1) Clastics

SDC +10 (subarkose)

$\mathrm{SBH}+5$ (quartz arenite)

$\mathrm{HE}+20$ (arkose)

(2) Volcaniclastics

SDC +60 (perfect)

$\mathrm{SBH}+5$ (negligible)

HE +10 (some)

(3) Reductants

SDC +30 (sulfides)

$\mathrm{SBH}+40$ (plant trash)

$\mathrm{HE}+10$ (faults present) 
(4) Sandstone-shale

SDC +35 (the most favorable proportions)

$\mathrm{SBH}+20$ (excess shale)

$\mathrm{HE}+35$ (the most favorable proportions)

(5) Composition score

Fe SDC $=10+60+30+35=+135$
Fe SBH $=5+5+40+20=+70$
Fe HE $=20+10+10+35=+75$
Fna SDC $=\frac{135}{155} \times 70=+61$ (out of a possible 70)
Fna SBH $=\frac{70}{155} \times 70=+32$ (out of a possible 70)
Fna HE $=\frac{75}{155} \times 70=+34$ (out of a possible 70)

(f) Host Sandstone Score

Fe SDC $=20+15+15+60+61=+171$

$\mathrm{Fe} \mathrm{SBH}=$ Pos $20+15+30+32=+97$

Neg $-20 \quad=\quad-20$

$\mathrm{Fe} \mathrm{HE}=20+15+15+60+34=+144$

Fna SDC $\quad=\frac{171}{180} \times 60=\underline{+57}$ (out of a possible 60)

Fna $\mathrm{SBH}$ Pos $=\frac{97}{180}=+.54$

Fna SBH Neg $=\frac{-20}{330} \quad=-.06$

Fna SBH Net $=+.54-.06=+.48$

Fna SBH $=\quad+.48 \times 60=+29$ (out of a possible 60 )

Fna HE $\quad=\frac{144}{180} \times 60=\underline{+48}$ (out of a possible 60) 
IV. Alteration and Mineralization

(a) A1teration

SDC +60 (diverse favorable alteration)

SBH -20 (minimal favorable alteration)

$\mathrm{HE} \quad+60$ (diverse favorable alteration)

(b) Mineralization

SDC +80 (several anomalies)

$\mathrm{SBH}+80$ (as above)

$\mathrm{HE} \quad+40$ (few anomalies)

(c) Alteration and Mineralization Score

$$
\begin{aligned}
& \text { Fe SDC }=60+80=+140 \\
& \text { Fe SBH }=\text { Pos }+80=+80 \\
& \text { Neg }-20=-20 \\
& \text { Fe HE } \quad=60+40=+100 \\
& \text { Fna SDC } \quad=\frac{140}{140} \times 75=+75 \text { (perfect score) } \\
& \text { Fna } \mathrm{SBH} \text { Pos }=\frac{80}{140}=+.57 \\
& \text { Fna SBH Neg }=\frac{-20}{130}=-.15 \\
& \text { Fna SBH Net }=.57-.15=+.42 \\
& \text { Fna } \mathrm{SBH}=+.42 \times 75=\quad+31 \text { (out of a possible } 75 \text { ) } \\
& \text { Fna } \mathrm{HE} \quad=\frac{100}{140} \times 75=+54 \text { (out of a possible 75) }
\end{aligned}
$$

The favorability estimates for the second-level intermediate criteria, calculated above, can now be tabulated in preparation for calculating the favorability estimates for South Texas-type deposits in these three areas: 
Second-Leve1 Criterion

Tectonic, Structural, and Regional Geologic Setting

Sedimentary Sequence

Host Sands tone

Alteration and Mineralization
Applied Normalized

Favorability Values

\begin{tabular}{|c|c|c|}
\hline South & Southern & \\
\hline Duval & Black & Houston \\
\hline County & Hills & Embayment \\
\hline
\end{tabular}

25

30

30

0

25

Maximum

Applied

Normalized

Favorability

44

0

31

50

57

29

48

60

75

54

75

The favorability for South Texas-type deposits in these three areas is calculated using the data above and the same procedures used in the preceding calculations.

$$
\begin{aligned}
& \mathrm{Fe} \mathrm{SDC}=30+44+57+75=+206 \\
& \mathrm{Fe} \mathrm{SBH}=0+0+29+31=+60 \\
& \mathrm{Fe} \mathrm{HE}=25+31+48+54=+158 \\
& \mathrm{Fm}+\quad=30+50+60+75=+215 \\
& \text { Fn SDC }=\frac{206}{215} \times 100=96 \% \\
& \text { Fn SBH }=\frac{60}{215} \times 100=28 \% \\
& \text { Fn HE }=\frac{158}{215} \times 100=73 \%
\end{aligned}
$$

These results suggest that South Duval County is, not surprisingly, favorable for the occurrence of South Texas-type deposits.

The Southern Black Hills, however, scored quite low, suggesting the area is not favorable for the presence of this type of deposit. The Houston Embayment has many of the geologic characteristics necessary for ore occurrence, but it is substantially less favorable than the South Duval area. Inspection would have to be made of the favorabilities of individual recognition criteria in order to determine whether or not the Houston Embayment has potent 1al worth pursuing. As discussed in the text, the relationship between geologic favorability and the probability of a deposit being present has not been established with any reasonable confidence. Although we have presented a schematic relationship in Figure 35, it should be used with caution because the actual relationship may be quite different and substantially more complicated. 
-

- 


\section{SELECTED REFERENCES}

Alt, D., 1968, Pattern of post-Miocene eustatic fluctuation of sea 1eve1: Palaeogeography, Palaeoclimatology, Palaeoecology, v. 5, p. 87-94.

Austin, S. R., 1970, Some patterns of sulfur isotope distribution in uranium deposits: Wyoming Geological Association Earth Science Bulletin, v. 3, no. 2 , p. 5-20.

Baker, E. T., Jr., 1979, Stratigraphic and hydrogeologic framework of part of the Coastal Plain of Texas: Texas Department of Water Resources Report $236,43 \mathrm{p}$.

Bandy, 0. L., 1968, Cycles in Neogene paleo-oceanography and eustatic changes: Palaeogeography, Palaeoclimatology, Palaeoecology, v. 5, p. 63-75.

Barnes, V. E., 1974, Geologic atlas of Texas: Austin sheet: University of Texas, Austin, Bureau of Economic Geology, scale 1:250,000.

Barnes, V. E., 1974, Geologic atlas of Texas: San Antonio sheet: University of Texas, Austin, Bureau of Economic Geology, scale 1:250,000.

Barnes, V. E., 1974, Geologic atlas of Texas: Sequin sheet: Untversity of Texas, Austin, Bureau of Economic Geology, scale 1:250,000.

Barnes, V. E., 1975, Geologic atlas of Texas: Beeville sheet: University of Texas, Austin, Bureau of Economic Geology, scale 1:250,000.

Barnes, V. E., 1975, Geologic atlas of Texas: Corpus Christi sheet: University of Texas, Austin, Bureau of Economic Geology, scale 1:250,000.

Barnes, V. E., 1976, Geologic atlas of Texas: Crystal City-Eagle Pass sheet: University of Texas, Austin, Bureau of Economic Geology, scale 1:250,000.

Barnes, V. E., 1976, Geologic atlas of Texas: Laredo sheet: University of Texas, Austin, Bureau of Economic Geology, scale 1:250,000.

Bebout, D. G., Agagu, O. K., and Dorfman, M. H., 1975a, Geothermal resources of the Frio Formation, middle Texas Gulf Coast: University of Texas, Austin, Bureau of Economic Geology Geological Circular 75-8, 43 p.

Bebout, D. G., Dorfman, M. H., and Agagu, O. K., 1975b, Geothermal resources of the Frio Formation, South Texas: University of Texas, Austin, Bureau of Economic Geology Geological Circular 75-1, 36 p.

Bebout, D. G., Loucks, R. G., and Gregory, A. R., 1978, Frto sandstone reservolrs: University of Texas, Austin, Bureau of Economic Geology Report 91,93 p.

Belcher, R. C., 1975, The geomorphic evolution of the Rio Grande: Waco, Texas, Baylor Geological Studies, Bulletin 29, 64 p. 
Berg, R. R., 1970, Preface, in Berg, R. R., ed., Outcrops of the Claiborne Group (Middle Eocene) in the Brazos Valley, southeast Texas: Geological Society of America, South-Central Section, Field Trip Guidebook for the 4th Annual Meeting, p. 1-3.

Berggren, W. A., and Van Couvering, J. A., 1974, The late Neogene: Biostratigraphy, geochronology and paleoclimatology of the last 15 million years in marine and continental sequences: Palaeogeography, Palaeoclimatology, Palaeoecology, v. 16, no. 1/2, 216 p.

Bernard, H. A., and LeBlanc, R. J., 1965, Resume of the Quaternary geology of the northwestern Gulf of Mexico Province, in The Quaternary of the United States: Princeton, New Jersey, Princeton University Press, p. 137-185.

Boenig, C. M., 1970, Deltaic and coastal interdeltalc environments of the Carrizo Formation (Eocene), Milam County, Texas: Texas A\&M University Master's thesis, $104 \mathrm{p}$.

Bomber, B. J., Ledger, E. B., and Tieh, T. T., 1980, Textural study of a sedimentary uranium deposit in South Texas: Geological Society of America Annual Meeting, Atlanta, Georgia, Abstracts with programs, p. 389.

Brewton, J. L., 1970, Heavy mineral distribution in the Carrizo Formation (Eocene), East Texas: University of Texas, Austin, Ph.D. dissertation, $167 \mathrm{p}$.

Bruce, C. H., 1972, Pressured shale and related sediment deformation; a mechanism for development of regional contemporaneous faults: Gulf Coast Association of Geological Societies Transactions, v. 22, p. 23-31.

Bunker, C. M., and Mackallor, J. A., 1973, Geology of the oxidized uranium ore deposits of the Tordilla Hill-Deweesville area, Karnes County, Texas; a study of a district before mining: U.S. Geological Survey Professional Paper $765,37 \mathrm{p}$.

Burke, R. A., 1958, Summary of ofl occurrence in Anahuac and Frio Formations of Texas and Louisiana: American Assoctation of Petroleum Geologists Bulletin, v. 42, no. 12, p. 2935-2950.

Busche, F. D., Goldhaber, M. B., and Reynolds, R. L., in press, Fault-leaked $\mathrm{H}_{2} \mathrm{~S}$ and the origin of South Texas uranium deposits: Implications of sulfur isotopic studies: Geological Society of America, Regional Meeting, San Antonio, Texas, 1981, Abstracts with programs.

Calendar, D. L., 1957, Petrology of the Queen City Sand, Bastrop County, Texas: University of Texas, Austin, Master's thesis.

Calendar, D. L., and Folk, R. L., 1958, Idiomorphic zircon, key to volcanism in the lower Tertiary sands of central Texas: American Journal of Science, v. 256, no. 4, p. 257-269. 
Cargil1, S. M., and Clark, A., eds., 1978, Standards for computer applications in resource studies-a conference held as part of the International Geological Correlations Program, Project 98, Taita Hills, Kenya, November 8-15, 1979, published as Journal of the International Association for Mathematical Geology, v. 10, no. 5, p. 405-642.

Dially, G. C., 1976, A possible mechanism relating progradation, growth faulting, clay diapirism and overthrusting in a regressive sequence of sediments: Canadian Petroleum Geology, v. 24, no. 1, p. 92-116.

Dickinson, K. A., 1976a, Sedimentary depositional environments of uranium and petroleum host rocks of the Jackson Group, South Texas: U.S. Geological Survey Journal of Research, v. 4, no. 5, p. 615-629.

Dickinson, K. A., 1976b, Uranium potential of the Texas Coastal Plain: U.S. Geological Survey Open-File Report 76-879, 7 p.

Dickinson, K. A., 1976c, Geologic controls of uranium deposition, Karnes County, Texas: U.S. Geological Survey Open-File Report 76-331, 16 p.

Dickinson, K. A., and Sullivan, M. W., 1976, Geology of the Brysch uranium mine, Karnes County, Texas: U.S. Geological Survey Journal of Research, v. 4 , no. 4, p. 397-404.

Doering, J. A., 1956, Review of Quaternary surface formations of the Gulf Coast region: American Association of Petroleum Geologists Bulletin, v. 40 , no. 8 , p. $1816-1862$.

Dorfinan, M., and Kehle, R. O., 1974, Potential geothermal resources of Texas: University of Texas, Austin, Bureau of Economic Geology Geological Circular 74-4, $33 \mathrm{p}$.

Duessen, A., 1924, Geology of the Coastal Plain of Texas west of the Brazos River: U.S. Geological Survey Professional Paper 126, 145 p.

Duex, T. W., 1971, K/Ar dates and U, K geochemistry of the Gueydan (Catahoula) Formation, in Adams, J. A. S., ed., Final report: U.S. Atomic Energy Commission Research Contract AT (05-1)-935, pt. 7, p. 101-145.

Dumble, E. T., 1924, A revision of the Texas Tertiary section with special reference to the oil well geology of the coast region: American Association of Petroleum Geologists Bulletin, v. 8, p. 424-444.

Eargle, D. H., 1959, Stratigraphy of the Jackson Group (Eocene), south-central Texas: Bulletin of the American Association of Petroleum Geologists, v. 43, no. 11 , p. 2623-2635.

Eargle, D. H., 1968, Nomenclature of formations of the Claiborne Group, Middle Eocene coastal plain of Texas: U.S. Geological Survey Bulletin 1251-D, 25 p.

Eargle, D. H., 1972, Revised classification and nomenclature of the Jackson Group (Eocene), south-central Texas: American Association of Petroleum Geologists Bulletin, v. 56, no. 3, p. 561-566. 
Eargle, D. H., Dickinson, K. A., and Davis, B. 0., 1975, South Texas uranium deposits: American Assoclation of Petroleum Geologists Bulletin, v. 59, no. 5, p. 766-779.

Eargle, D. H., and Snider, J. L., 1957, A preliminary report on the stratigraphy of the uranium-bearing rocks of the Karnes County area, southcentral Texas: University of Texas, Austin, Bureau of Economic Geology Report of Investigations $30,30 \mathrm{p}$.

Eargle, D. H., and Weeks, A. M. D., 1961, Possible relations between hydrogen sulfide-bearing hydrocarbons in fault line oll fields and uranium deposits in the Southeast Texas Coastal Plain: U.S. Geological Survey Professional Paper 424D, p. 7-9.

Eargle, D. H., and Weeks, A. M. D., 1973, Geolog1c relations among uranium deposits, South Texas, coastal plain region, U.S.A., in Amstutz, G. C., and Bernard, A. J., eds., Ores in sediments: Heldelberg, International Union of Geological Sciences Series A, no. 3, p. 101-113.

E1-Atrash, M. E., 1971, Foraminifera and biostratigraphy of the Kincaid Formation (Paleocene) in northeast Texas: Texas Christian University Master's thesis, $123 \mathrm{p}$.

Feray, D. E., and Renfro, H. B., 1972, Tectonic map of the Gulf Coast region, U.S.A.: Tulsa, Oklahoma, Gulf Coast Association of Geological Societies and American Association of Petroleum Geologists.

Fisher, W. L., 1961, Stratigraphic names in the Midway and Wilcox Groups of the coastal plain: University of Texas, Austin, Bureau of Economic Geology Report 44, p. 263-295.

Fisher, W. L., 1968, Basic delta systems in the Eocene of the Gulf Coast Basin (absa): Gulf Coast Association of Geological Societies Transactions, v. 18, p. 48 .

Fisher, W. L., 1969, Facies characterization of Gulf Coast Basin delta systems with some Holocene analogies: Gulf Coast Association of Geological Societies Transactions, v. 19, p. 239-261.

Fisher, W. L., and McGowen, J. H., 1967, Depositional systems in the Wilcox Group of Texas and their relationship to occurrence of oil and gas: Gulf Coast Association of Geological Socteties Transactions, v. 17, p. 105-125.

Fisher, W. L., Proctor, C. V., Jr., Galloway, W. E., and Nagle, J. S., 1970, Depositional systems in the Jackson Group of Texas--their relationship to oil, gas and uranium: Gulf Coast Association of Geological Societies Transactions, v. 20, p. 234-261.

Fisk, H. N., 1944, Geologic investigation of the alluvial valley of the lower Mississippi River: Vicksburg, Mississippi, U.S. Army Corps of Engineers, Mississippi River Commission, 78 p. 
Frazier, D., 1974, Depositional episodes: Their relationship to the Quaternary stratigraphic framework in the northwestern portion of the Gulf Basin: University of Texas, Austin, Bureau of Economic Geology Geological Circular 74-1, 28 p.

Galloway, W. E., 1977, Catahoula Formation of the Texas Coastal Plain: Depositional systems, composition, structural development, groundwater flow history, and uranium distribution: University of Texas, Austin, Bureau of Economic Geology Report 87, 59 p.

Galloway, W. E., and Kaiser, W. R., 1979, Catahoula Formation of the Texas Coastal Plain: Origin, geochemical evolution and characteristics of uranium deposits: Grand Junction, Colorado, Bendix Field Engineering Corporation GJBX-131(79), 139 p.

Galloway, W. E., Finley, R. J., and Henry, C. D., 1979a, South Texas uranium province geologic perspective: Universtty of Texas, Austin, Bureau of Economic Geology Guidebook 18, 81 p.

Galloway, W. E., Kreitler, C. W., and McGowen, J. H., 1979b, Depositional and ground-water flow systems in the exploration for uranium-a research colloquium: University of Texas, Austin, Bureau of Economic Geology, 267 p.

Gardner, J., 1938, Laredo--a new name for a unit of Cook Mountain age in the Rio Grande region: Washington Academy of Sciences Journal, v. 28, no. 7, p. 297-298.

Garner, L. E., 1967, Sand resources of the Texas Gulf Coast: University of Texas, Austin, Bureau of Economic Geology Report of Investigation 60, 85 p.

Garner, L. E., St. Clair, A. E., and Evans, T. J., 1979, Mineral resources of Texas: Untversity of Texas, Austin, Bureau of Economic Geology, scale $1: 1,000,000$.

Gaschnig, J., 1980, Development of uranium exploration models for the Prospector consultant system: Menlo Park, California, SRI International Project 7856,603 p.

Geodata International, Inc., 1979, Aerial radiometric and magnetic survey, Corpus Christi/Laredo national topographic maps, Texas Gulf Coast: Grand Junction, Colorado, Bendix Field Englneering Corporation GJBX-99(79), v. 1,154 p.

Geomap Company, 1979, Executive map for the Southwest Texas Gulf Coast-Map 313: Dallas, Texas, Geomap Company.

Goldhaber, M. B., and Reynolds, R. L., 1979, Origin of marcasite and its implications regarding the genesis of roll-front uranium deposits: U.S. Geological Survey Open-File Report 79-1696, 38 p.

Goldhaber, M. B., Reynolds, R. L., and Rye, R. 0., 1978, Origin of a South Texas roll-type uranium deposit: II. Sulfide petrology and sulfur 1sotope studies: Economic Geology, v. 73, p. 1690-1705. 
Goldhaber, M. B., Reynolds, R. L., and Rye, R. 0., 1979, Formation and resulfidization of a South Texas roll-type uranium deposit: U.S. Geological Survey Open-File Report 79-1651, 41 p.

Guevara, E. H., and Garcla, R., 1972, Depositional systems and ofl-gas reservoirs in the Queen City Formation (Eocene), Texas: Gulf Coast Association of Geological Societies Transactions, v. 22, p. 1-22.

Harris, D. P., and Carrigan, F. J., 1980, A probabilistic endowment appraisa1 system based upon the formalization of geologic decisions, a general description: Grand Junction, Colorado, U.S. Department of Energy, 114 p.

Harshman, E. N., 1974, Distribution of elements in some roll-type uranium deposits, in Formation of uranium ore deposits: Athens, International Atomic Energy Agency, p. 169-183.

Harshman, E. N., and Adams, S. S., 1981, Geology and recognition criteria for roll-type uranium deposits in continental sandstones: Grand Junction, Colorado, Bendix Field Engineering Corporation GJBX-1(81), 185 p.

Hart, P. E., Duda, R. 0., and Einaudi, M. T., 1978, Prospector--a computerbased consultation system for mineral exploration: Journal of the International Association for Mathematical Geology, v. 10, no. 5, p. 598-610.

Henry, C. D., 1976, Land resources inventory of lignite strip-mining areas, East Texas: University of Texas, Austin, Bureau of Economic Geology Geological Circular 76-2, 28 p.

Imbrie, J., and Imbrie, K. P., 1979, Ice ages: Solving the mystery: Short Hills, New Jersey, Enslow Publishers, 224 p.

Johnston, J. E., 1977, Depositional systems in the Wilcox Group and the Carrizo Formation (Eocene) of Central and South Texas and their relationship to lignite: University of Texas, Austin, Master's thesis, $113 \mathrm{p}$.

Jones, P. H., and Wallace, R. H., Jr., 1974, Hydrogeologic aspects of structura1 deformation in the northern Gulf of Mexico Basin: U.S. Geological Survey Journal of Research, v. 2, no. 5, p. 511-517.

Kaiser, W. R., 1974, Texas lignite: Near-surface and deep-basin resources: University of Texas, Austin, Bureau of Economic Geology Report 79, 70 p.

Kaiser, W. R., Johnston, J. E., and Bach, W. N., 1978, Sand body geometry and the occurrence of lignite in the Eocene of Texas: University of Texas, Austin, Bureau of Economic Geology Geological Circular 78-4, 19 p.

Kehle, R. 0., 1972, Origin of the Gulf of Mexico: University of Texas, Austin, Department of Geological Sciences unpublished paper.

Keller, G. R., and Cebu11, S. E., 1973, Plate tectonics and the Ouachita system in Texas, Oklahoma, and Arkansas: Geological Society of America Bulletin, v. 84, no. 5, p. 1659-1665. 
Kelloagh, G. R., 1965, Paleoecology of foraminifera from the Wills Point Formation (Midway Group) in northeastern Texas: American Association of Petroleum Geologists Bulletin, v. 49, no. 10, p. 1753.

Kennedy, W., 1892, A section from Terrel1, Kaufman County to Sabine Pass on the Gulf of Mexico: Texas Geological Survey Annual Report, v. 3, p. 41125 .

Klohn, M. L., and Pickens, W. R., 1970, Geology of the Felder uranium deposit, Live Oak County, Texas: Society of Mining Engineers of the American Institute of Mining, Metallurgical and Petroleum Engineers, Preprint No. $70-1-38,19 \mathrm{p}$.

Kohls, D. W., 1963, Simsboro and adjacent formations between the Brazos and Trinity Rivers, Texas--1ithology and clay mineralogy: Gulf Coast Association of Geological Societies Transactions, v. 13, p. 111-117.

Lentz, R. C., 1975, Relations of Eocene depositional environments to sulfur content and quality of surface waters at lignite strip mines near Fairfield, Texas: University of Texas, Austin, Ph.D. dissertation, 148 p.

Loucks, R. G., Bebout, D. G., and Galloway, W. E., 1977, Relationship of porosity formation and preservation to sandstone consolidation history-Gulf Coast Lower Tertiary Formation: Gulf Coast Association of Geological Socleties Transactions, v. 27, p. 109-120.

Lowman, S. W., 1949, Sedimentary facies in Gulf Coast: American Association of Petroleum Geologists Bulletin, v. 33, no. 12, p. 1939-1997.

Matthews, R. K., 1974, Dynamic stratigraphy: Englewood Cliffs, New Jersey, Prentice-Ha11, Inc., 370 p.

McBride, E. F., Lindemann, W. L., and Freeman, P. S., 1968, Lithology and petrology of the Gueydan (Catahoula) Formation in South Texas: University of Texas, Austin, Bureau of Economic Geology Report of Investigation 63, $122 \mathrm{p}$.

McGowen, J. H., and Garner, L. E., 1970, Physiographic features and stratification types of coarse-grained point bars: Modern and ancient examples: University of Texas, Austin, Bureau of Economic Geology Geological Circular 75-9, 27 p.

McGowen, J. H., Garner, L. E., and Wilkinson, B. H., 1977, The gulf shoreline of Texas: Processes, characteristics, and factors in use: University of Texas, Austin, Bureau of Economic Geology Geological Circular 77-3, 27 p.

Mcknight, W. M., Jr., 1972, A review of South Texas uranium geology: Gulf Coast Association of Geological Societies Transactions, v. 22, p. 97-103.

Moxham, R. M., 1964, Radioelement dispersion in a sedimentary environment and its effect on uranium exploration: Economic Geology, v. 59, no. 2, p. 309-321. 
Patton, T. H., 1966, Miocene and Pliocene artiodactyls, Texas Gulf Coastal Plain: University of Texas, Austin, Ph.D. dissertation, 166 p.

Payne, J. N., 1968, Hydrologic significance of the lithofacies of the Sparta Sand: U.S. Geological Survey Professional Paper 569-A, p. A3-A5.

Payne, J. N., 1975, Geohydrologic significance of lithofacies of the Carrizo Sand of Arkansas, Louisiana, and Texas and the Meridan Sand of Mississippi: U.S. Geological Survey Professional Paper 569-D, 11 p.

Peckham, R. C., 1965, Availability and qual1ty of groundwater in Leon County, Texas: Texas Water Commission Bulletin 6513, $44 \mathrm{p}$.

Peppard-Souders and Associates, 1979, Executive reference map no. 313, southeast Texas Gulf Coast, 1979 edition: Dallas, Texas.

Plummer, F. B., 1932, Cenozoic systems in Texas, in The geology of Texas, v. 1, Stratigraphy: University of Texas Bulletin 3232, p. 519-818.

Price, W. A., 1933, Reynosa problem of South Texas and the origin of caliche: American Association of Petroleum Geologists Bulletin, v. 17, p. 488-522.

Quick, J. V., Thomas, N. G., Brogdon, L. D., Jones, C. A., and Martin, T. S., 1977, Uranium favorability of Late Eocene through Pliocene rocks of the South Texas Coastal Plain: Grand Junction, Colorado, Bendix Field Engineering Corporation GJBX-7(77), 48 p.

Quinn, J. H., 1955, Miocene equidae of the Texas Gulf Coastal Plain: University of Texas Publication 5516, 102 p.

Ragsdale, J. A., 1960, Petrology of the Miocene Oakville Formation, Texas Coastal Plain: University of Texas, Austin, Master's thesis, 196 p.

Renick, B. C., 1926, The Jackson Group and the Catahoula and Oakville Formations in a part of the Texas Gulf Coastal Plain: University of Texas, Austin, Bulletin 2645, 187 p.

Renick, B. C., and Stenzel, H. B., 1931, The Lower Claiborne on the Brazos River, Texas: University of Texas, Austin, Bulletin 3101, p. 73-108.

Reynolds, R. L., and Goldhaber, M. B., 1978, Origin of a South Texas rol1type uranium deposit: I. Alteration of iron-titanium oxide minerals: Economic Geology, v. 73, p. 1677-1689.

Reynolds, R. L., and Goldhaber, M. B., 1979, Iron disulfide minerals and the origin of roll-type urantum deposits: Geological Society of America Annual Meeting, San Diego, California, Abstracts with programs.

Reynolds, R. L., Goldhaber, M. B., Rye, R. O., Fishman, N. S., Ludwig, K. R., and Grauch, R. I., 1980, History of sulfidization of the Felder uranium deposit, South Texas: U.S. Geological Survey Open-F1le Report 80-1096, $23 \mathrm{p}$. 
Ricoy, J. U., 1976, Depositional systems in the Sparta Formation (Eocene), Gulf Coast Basin of Texas: University of Texas, Austin, Master's thesis, $98 \mathrm{p}$.

Ricoy, J. U., and Brown, L. F., Jr., 1977, Depositional systems in the Sparta Formation (Eocene) Gulf Coast Basin of Texas: Gulf Coast Association of Geological Societies Transactions, v. 27, p. 139-154.

Rose, P. R., 1970, Stratigraphic interpretation of submarine versus subaerial discontinuity surfaces--an example from the Cretaceous of Texas: Geological Society of America Bulletin, v. 81, no. 9, p. 2787-2797.

Rose, P. R., 1971, Stratigraphic revision, Edwards Group (Lower Cretaceous) of Texas, and regional surface-subsurface synthesis (abs.): American Association of Petroleum Geologists Bulletin, v. 55, no. 2, p. 361.

Safford, J. M., 1956, A geological reconnaissance of the State of Tennessee: Nashville, Tennessee, Tennessee Geological Society, 164 p.

St. Clair, A. E., Evans, T. J., Gainer, L. E., Nemeth, K. E., and Bartow, W. P., 1976, Energy resources of Texas (map): University of Texas, Austin, Bureau of Economic Geology, scale 1:1,000,000.

Sellards, E. H., Adkins, W. S., and Plummer, R. B., 1932, The geology of Texas, v. 1, Stratigraphy: University of Texas, Austin, Bulletin 3232, 1007 p.

Sellards, E. H., and Baker, C. L., 1934, The geology of Texas, v. 2, Structural and economic geology: University of Texas, Austin, Bulletin 3401, 884 p.

Singer, D. A., and Ovenshine, A. T., 1979, Assessing Alaska's metal resources: American Scientist, v. 67, no. 5, p. 582-589.

Smith, R. B., 1977, The theory of multiple oxidation and reduction of uranium deposits in South Texas: South Texas Uranium Seminar, Corpus Christi, Texas, 1977.

Smith, R. B., 1979, Geology of South Texas uranium deposits, in South Texas Uranium Seminar: Denver, Colorado, Society of Mining Engineers of the American Institute of Mining, Metallurgical, and Petroleum Engineers, p. 45-46.

Stenze1, H. B., 1936, A new formation in the Claiborne Group: University of Texas, Austin, Bulletin 3501, p. 267-279.

Stephenson, L. W., 1953, Probable Reklaw age of the ferruginous conglomerate in eastern Texas: U.S. Geological Survey Professional Paper 243-C, p. 31-43.

Stuckey, C. W., and Woods, R. D., 1954, Stratigraphy of the upper Gulf Coast of Texas: Houston Geological Society Study Group Report 1953-1954, 26 p. 
Tedford, R. H., Galusha, T., and Skinner, M. F., 1973, Faunal succession and biostratigraphy of the Arikareean through Clarendonian interval (Miocene Epoch), North America (abs.): Geological Society of America Abstracts, v. 5, no. 7, p. 837-838.

Trowbridge, A. C., 1923, A geologic reconnaissance in the Gulf Coastal Plain of Texas near the Rio Grande: U.S. Geological Survey Professional Paper 131-D, p. 85-107.

Trowbridge, A. C., 1932, Tertiary and Quaternary geology of the lower Rio Grande region of Texas: U.S. Geological Survey Bulletin 837, p. 141-156.

Tucker, D. R., 1962, Subsurface Lower Cretaceous stratigraphy, Central Texas: University of Texas, Austin, Ph.D. dissertation, 137 p.

Union Carbide Corporation, 1979, Hydrogeochemical and stream sediment reconnaissance basic data for Laredo NTMS quadrangle, Texas: Oak Ridge, Tennessee, Dak Ridge Gaseous Diffusion Plant Report No. K/UR-131 [(GJBX$14(80)], 39 \mathrm{p}$.

Vail, P. R., Mitchum, R. M., Jr., Shipley, T. H., and Buffler, R. T., 1979, Unconformities of the North Atlantic, in The evolution of passive continental margins in the light of recent drilling results: Philosophical Transactions of the Royal Society of London.

Vail, P. R., Mitchum, R. M., Jr., and Thompson, S., III, 1977a, Relative changes of sea level from coastal onlap: American Association of Petroleum Geologists Memoir 26, p. 63-81.

Vail, P. R., Mitchum, R. M., Jr., and Thompson, S., III, 1977b. Global cycles of relative changes of sea level: American Association of Petroleum Geologists Memoir 26, p. 83-97.

Valentine, J. W., and Moores, E. M., 1970, Plate tectonic regulation of faunal diversity and sea level: A model: Nature, v. 228, p. 657-659.

Voelker, A. H., Wedow, H., Oakes, E., and Scheffler, P. K., 1979, A systematic method for resource rating with two applications to potential wilderness areas: Oak Ridge, Tennessee, Oak Ridge National Laboratory ORNL/TM-6739.

Waters, J. A., McFarland, P. W., and Lea, J. W., 1955, Geologic framework of the Gulf Coastal Plain of Texas: American Association of Petroleum Geologists Bulletin, v. 39, no. 9, p. 1821-1850.

Weeks, A. W., 1945, Balcones, Luling, and Mexia fault zones in Texas: American Association of Petroleum Geologists Bulletin, v. 29, no. 12, p. 1733-1737.

Weeks, A. D., and Eargle, D. H., 1960, Uranium at Palangana Salt Dome, Duval County, Texas, in Short papers in the geological sciences: U.S. Geological Survey professional Paper 400-B, p. B48-B52. 
Weeks, A. D., and Eargle, D. H., 1963, Relation of diagenetic alterations and soil-forming processes to the uranium deposits of the Southeast Texas Coastal Plain, in Clays and clay minerals, v. 10: 10th National Conference on Clays and Clay Minerals, 1961, Proceedings: New York, Macmillan Company, p. 23-41.

Wendlandt, E. A., and Knebe1, G. M., 1926, Lower Claiborne of East Texas, with special reference to Mount Sylvan dome and salt movements: American Association of Petroleum Geologists Bulletin, v. 13, p. 1347-1375.

Wilbert, W. P., and Templain, C. J., 1978, Preliminary study of uranium favorability of the Wilcox and Claiborne Groups (Eocene) in Texas: Grand Junction, Colorado, Bendix Field Engineering Corporation GJBX-7(78), 30 p.

Wilson, J. A., 1956, Miocene formations and vertebrate biostratigraphic units, Texas Coastal Plain: American Association of Petroleum Geologists Bulletin, v. 40, p. 2233-2246.

Wilson, J. A., 1960, Miocene carnivores, Texas Coastal Plain: Journal of Paleontology, v. 34, no. 5, p. 983-1000.

Wilson, J. A., 1968, Tertiary shorelines, Texas Coastal Plain: Palaeogeography, Palaeoclimatology, Palaeoecology, v. 5, p. 135-140.

Winslow, A. G., Doye1, W. W., and Wood, L. A., 1957, Salt water and its relation to fresh groundwater in Harris County, Texas: U.S. Geological Survey Water-Supply Paper 1360-F, p. 375-407.

Winslow, A. G., and Kister, L. R., 1956, Saline-water resources of Texas: U.S. Geological Survey Water-Supply Paper 1365, 45 p.

Wood, L. A., Gabrysch, R. K., and Marvin, R., 1963, Reconnaissance investigations of the groundwater resources of the Gulf Coast region, Texas: Texas Water Commission Bulletin 6305, 123 p.

Young, K. P., 1962, Mesozoic history, Llano region, in Geology of the Gulf Coast and Central Texas and guidebook of excursions: Geological Society of America, 1962 Annual Meeting, Houston, Texas: Houston Geological Society, p. 98-106. 
$$
\text { . }
$$ 
plate |

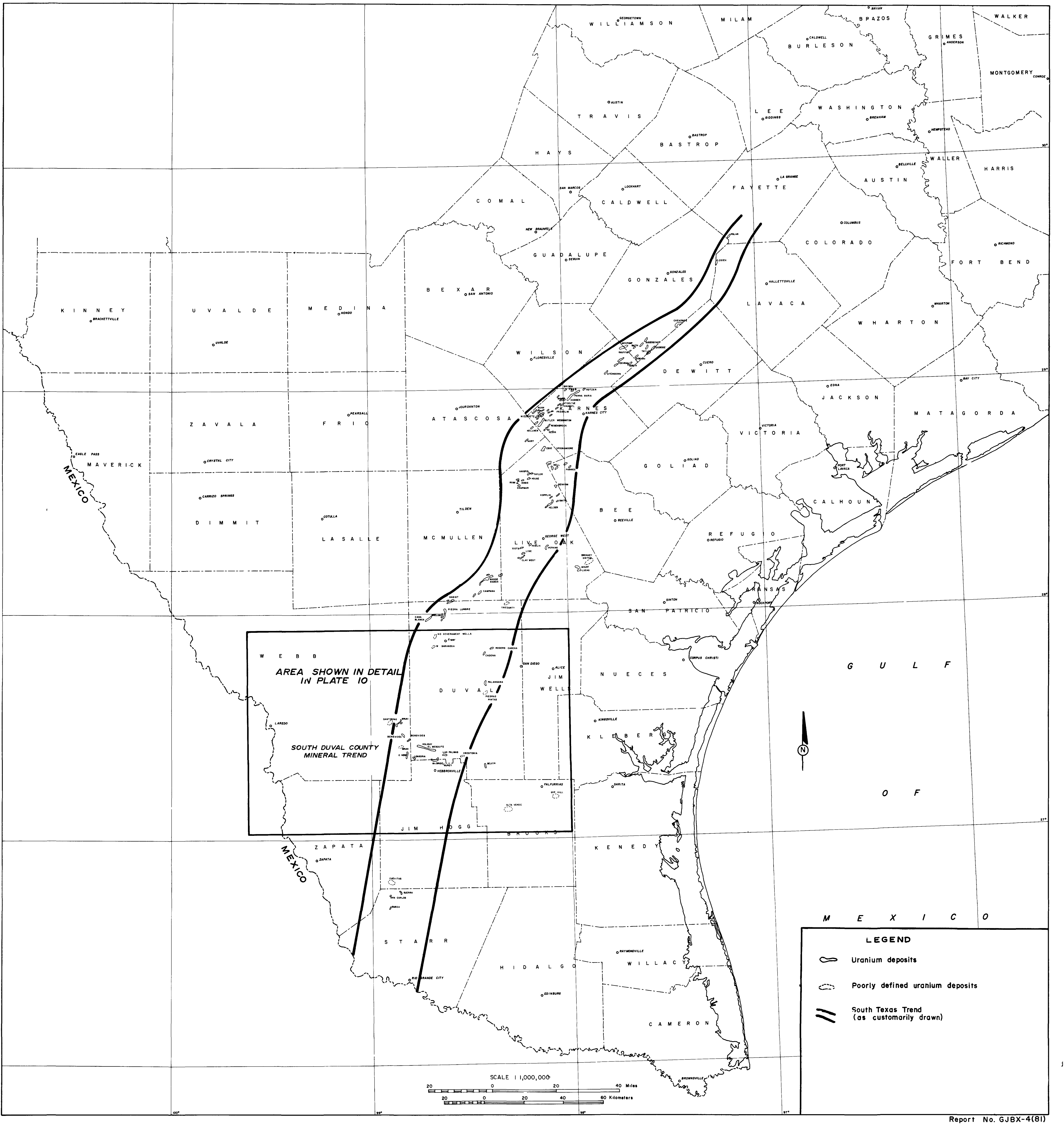


PLATE III






\begin{tabular}{|c|c|c|c|c|c|c|c|}
\hline GROUP & ZONE A & ZONE B & ZONE $\mathrm{C}$ & ZONE D & ZONE E & ZONE $F$ & EPOCH \\
\hline \multirow{2}{*}{$\begin{array}{l}\text { houson } \\
\text { croup }\end{array}$} & 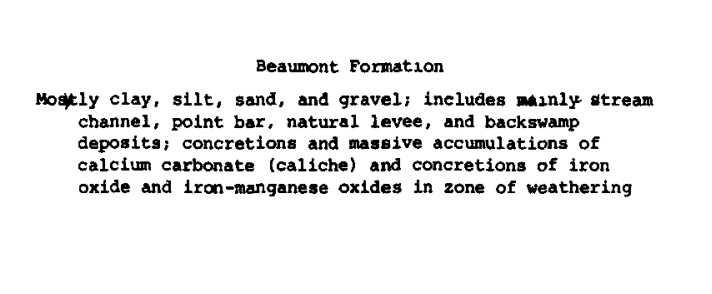 & 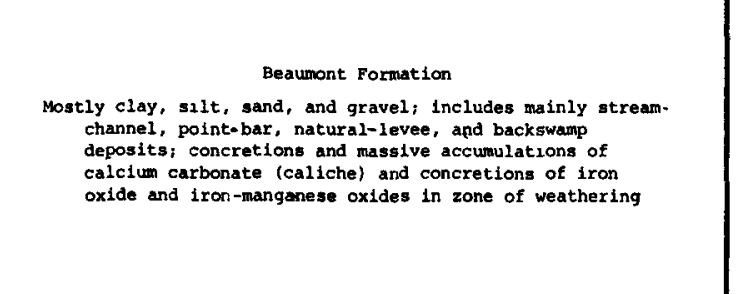 & 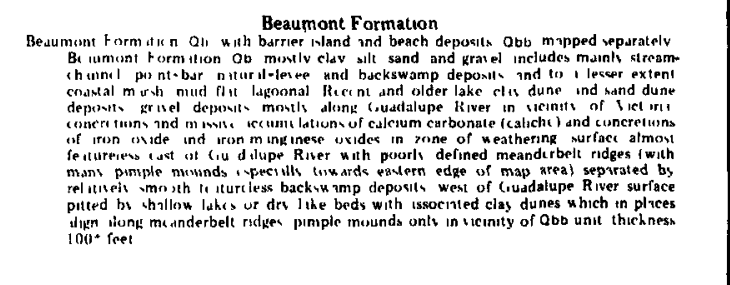 & 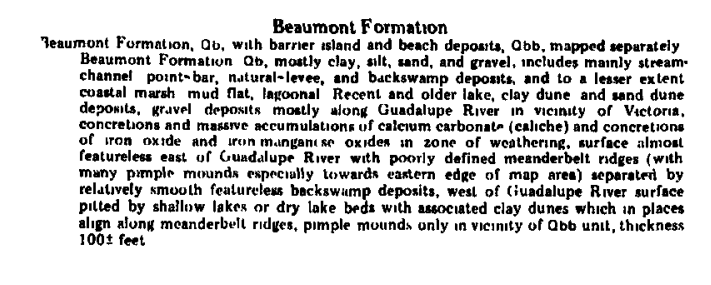 & 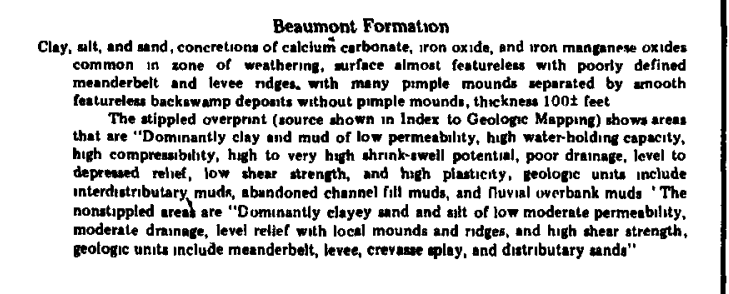 & & \multirow{2}{*}{ PLEISTOCENE } \\
\hline & $=5=$ & $=5=$ & $=3$ & 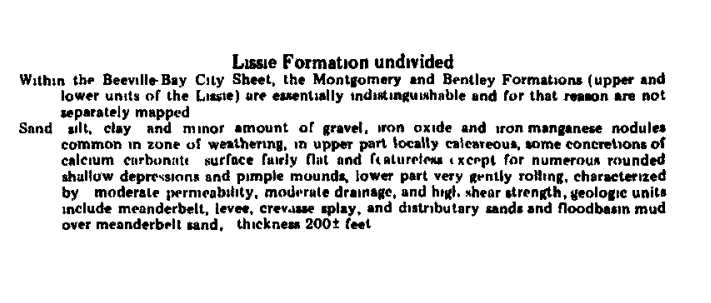 & $3=3$ & $3=3$ & \\
\hline \multirow{2}{*}{ 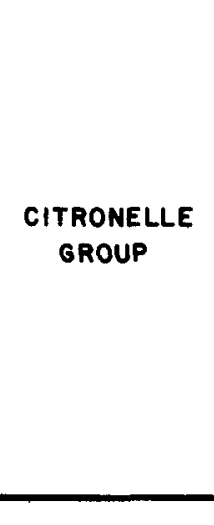 } & $=0$ & $\begin{aligned} y-5 & =3 \\
y & =3\end{aligned}$ & $y=3$ & $y^{2}-5=3$ & $3=3$ & $3=333$ & PLOCENe \\
\hline & 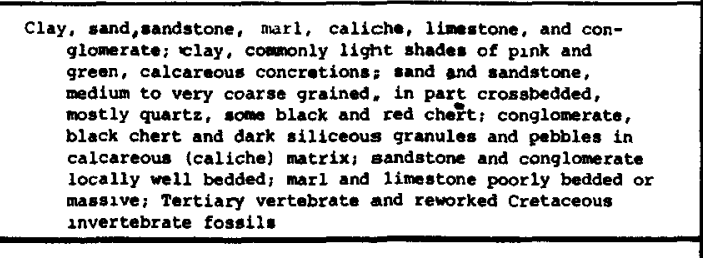 & 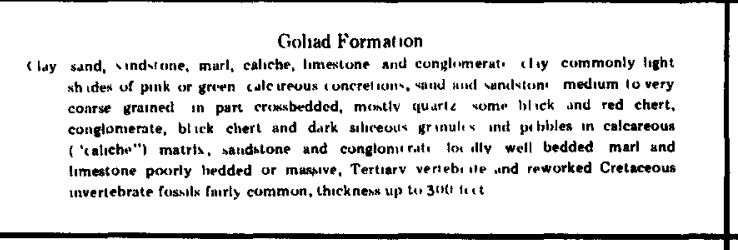 & $y=3$ & $v^{3}=53=3$ & $y=3$ & & 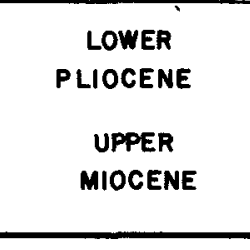 \\
\hline \multirow{2}{*}{ 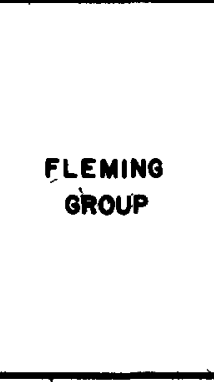 } & \multirow{2}{*}{$y=5$} & $y=$ & $53=$ & $y=-5=$ & $y=5$ & 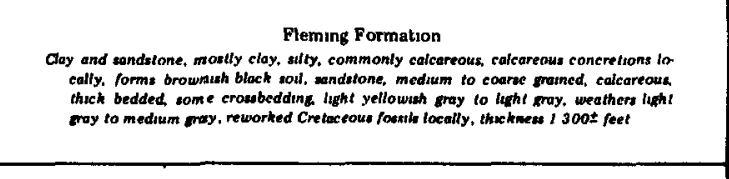 & 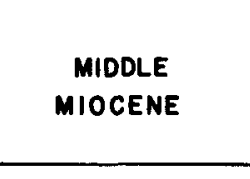 \\
\hline & & 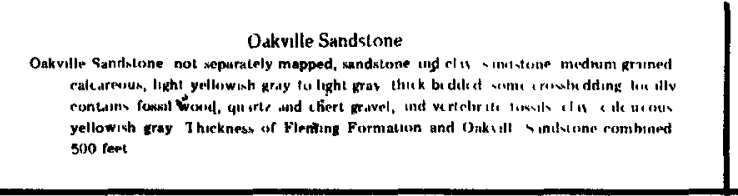 & $\equiv= \pm$ & 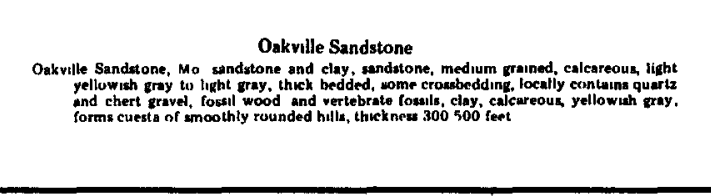 & 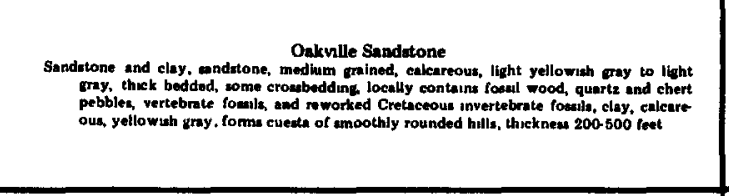 & $=3=3$ & 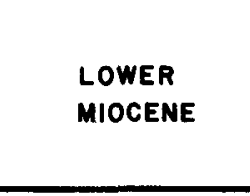 \\
\hline \multirow{4}{*}{ 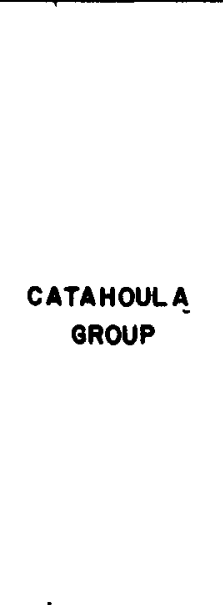 } & \multirow{4}{*}{ 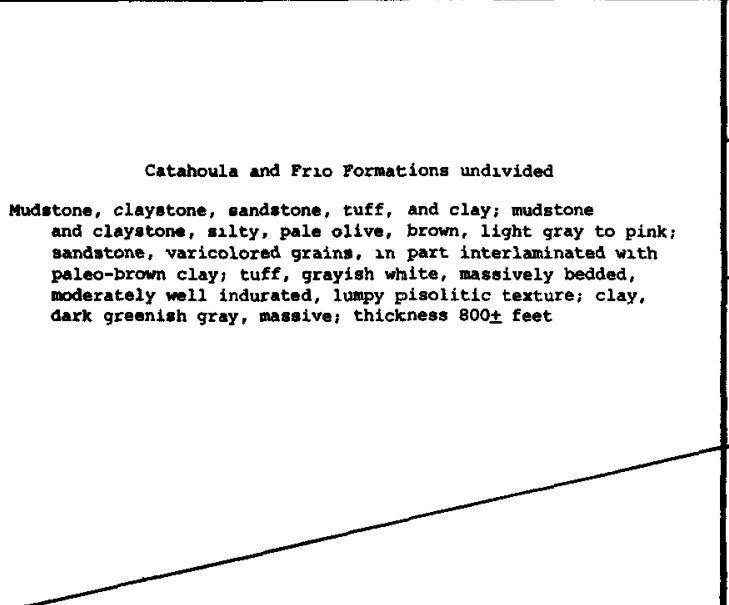 } & $=0$ & $-5=-5=$ & \multirow{4}{*}{ 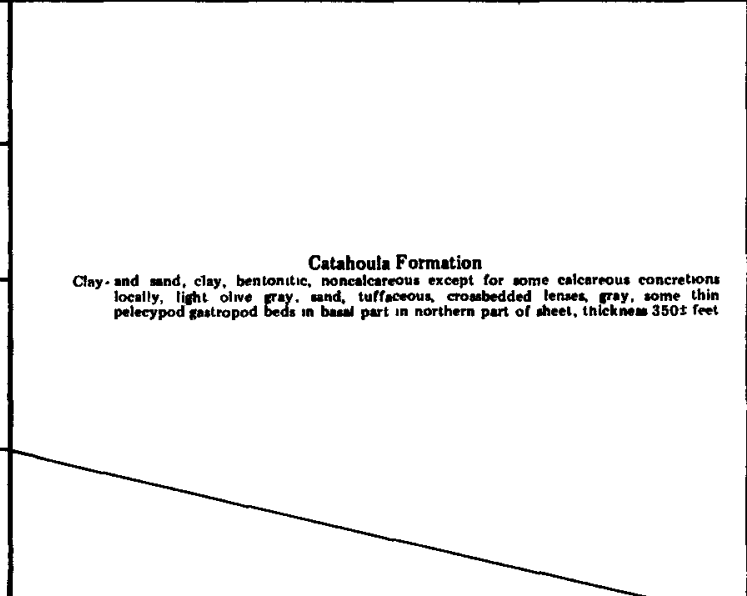 } & \multirow{4}{*}{$y=$} & \multirow{4}{*}{$y=5=$} & \multirow{4}{*}{ OLIOCCEAE } \\
\hline & & $y= \pm=n$ & $y=5$ & & & & \\
\hline & & $=5=$ & $y=-5=$ & & & & \\
\hline & & 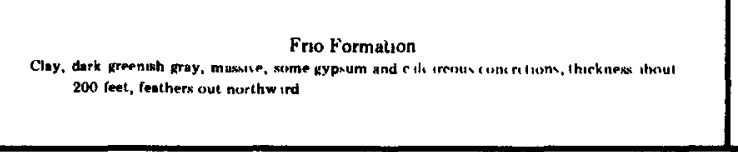 & $a_{n-1}=-\ldots$ & & & & \\
\hline \multirow{8}{*}{ 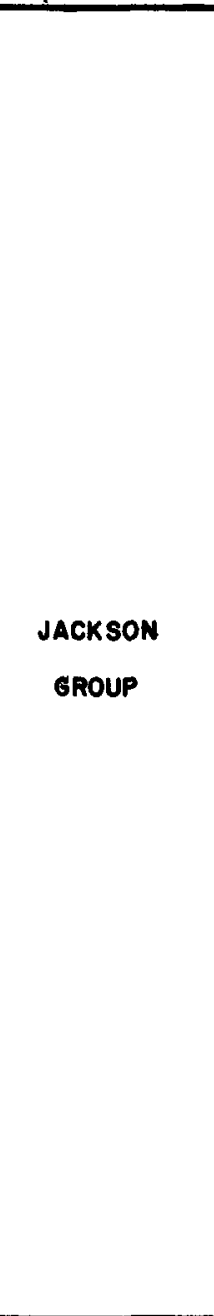 } & \multirow{8}{*}{$\begin{array}{l}y=y \\
y=y\end{array}$} & \multirow{8}{*}{$=3=$} & $\begin{array}{l}y=5= \\
y=-1\end{array}$ & & & \multirow{5}{*}{$=y=$} & \multirow{8}{*}{$\begin{array}{l}\text { uperen } \\
\text { Eocenes }\end{array}$} \\
\hline & & & $y=5=$ & $=0$ & $=-1=$ & & \\
\hline & & & $=5$ & 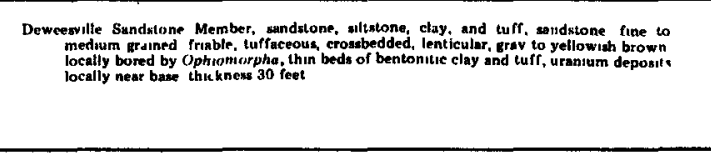 & $y=5=$ & & \\
\hline & & & $= \pm=$ & $=$ & 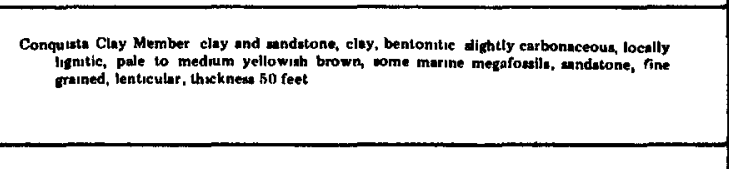 & & \\
\hline & & & $= \pm$ & $=$ & $=$ & & \\
\hline & & & $=3$ & 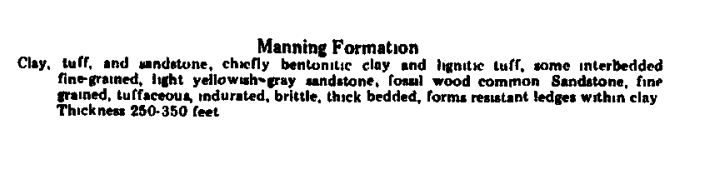 & 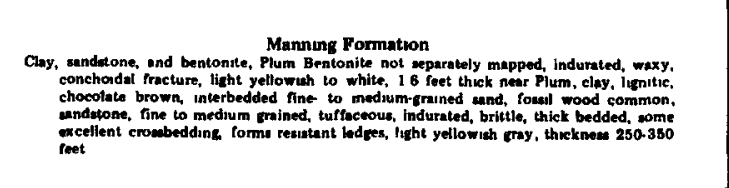 & $y=5$ & \\
\hline & & & $=$ & $-x=-1$ & $=3$ & $= \pm=5=5$ & \\
\hline & & & $y=5=$ & $= \pm=$ & $= \pm=$ & $= \pm= \pm$ & \\
\hline \multirow{7}{*}{ 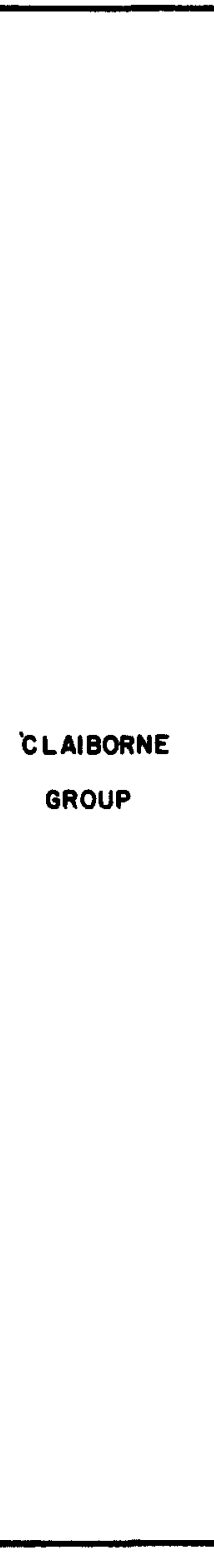 } & 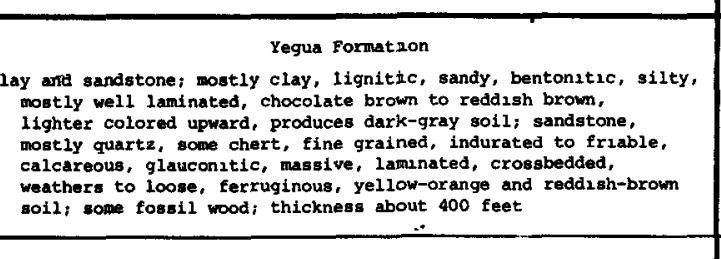 & $3=3$ & 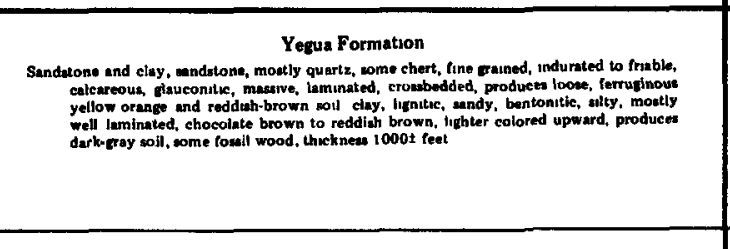 & 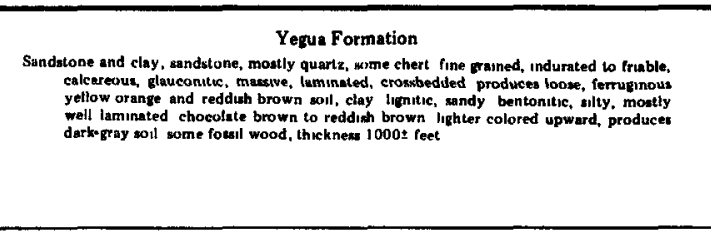 & $=3=3$ & 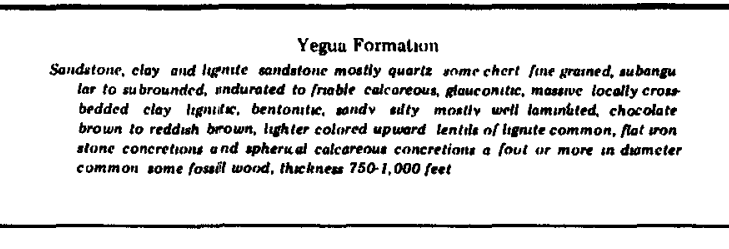 & \multirow{7}{*}{$\begin{array}{c}\text { MIOOLE } \\
\text { Eocene }\end{array}$} \\
\hline & \multirow{2}{*}{$= \pm=$} & \multirow{2}{*}{$y=$} & 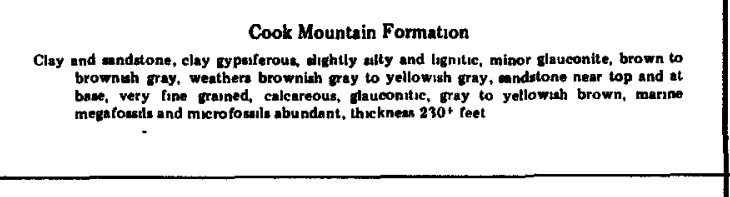 & 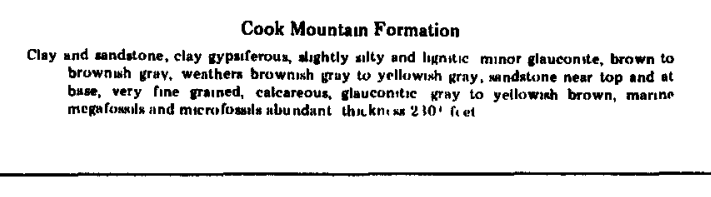 & 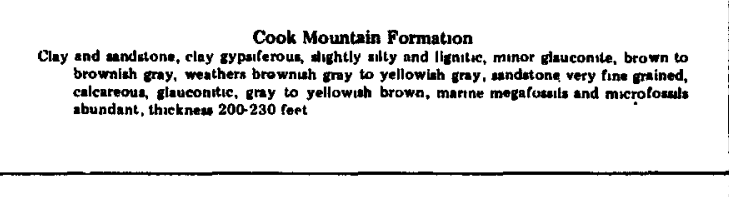 & $y=3$ & \\
\hline & & & $=5=$ & $=5$ & $y=5$ & $= \pm=$ & \\
\hline & \multirow{3}{*}{$y=5=5$} & & $y= \pm=$ & $y= \pm=$ & $=5=$ & 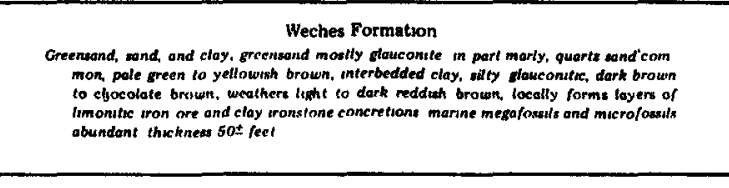 & \\
\hline & & $\begin{array}{l}=5=5 \\
\equiv\end{array}$ & $-3=5=5$ & $=5$ & $=2 y=$ & $= \pm= \pm=$ & \\
\hline & & & $\Rightarrow=5$ & $=5=$ & $=5=5$ & $y=3=5$ & \\
\hline & & $3 \pm=5$ & 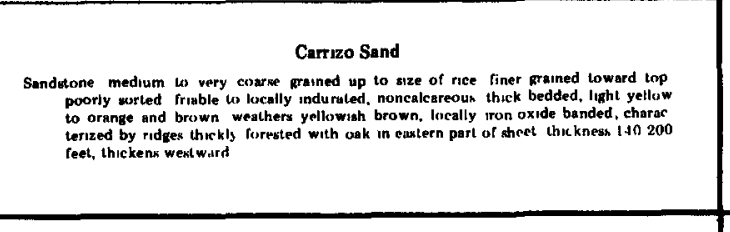 & 53 & $= \pm=5$ & $=5= \pm$ & \\
\hline $\begin{array}{l}\text { mecox } \\
\text { opoup }\end{array}$ & 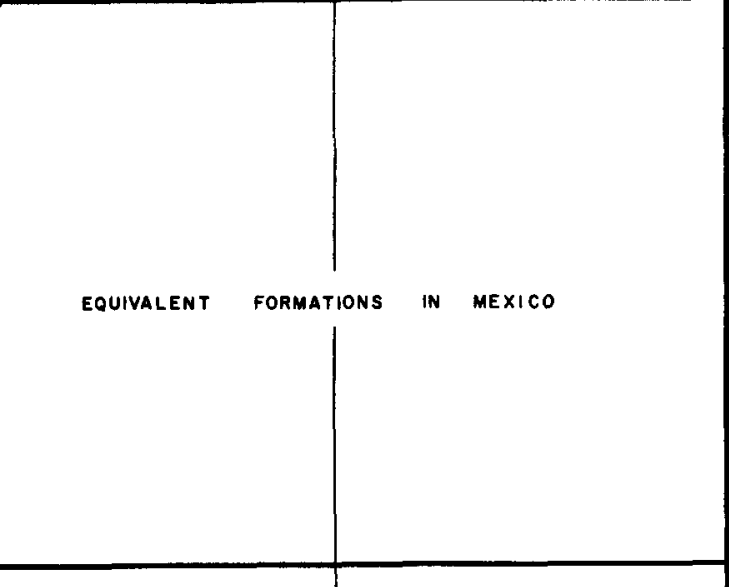 & 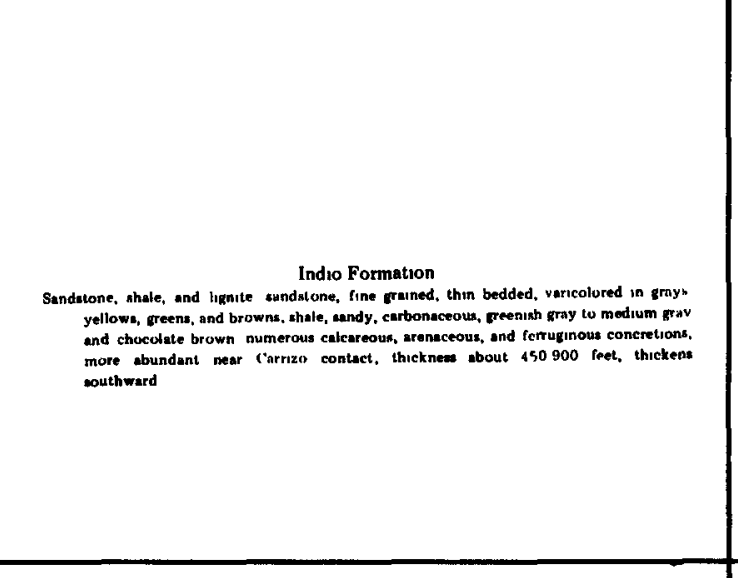 & 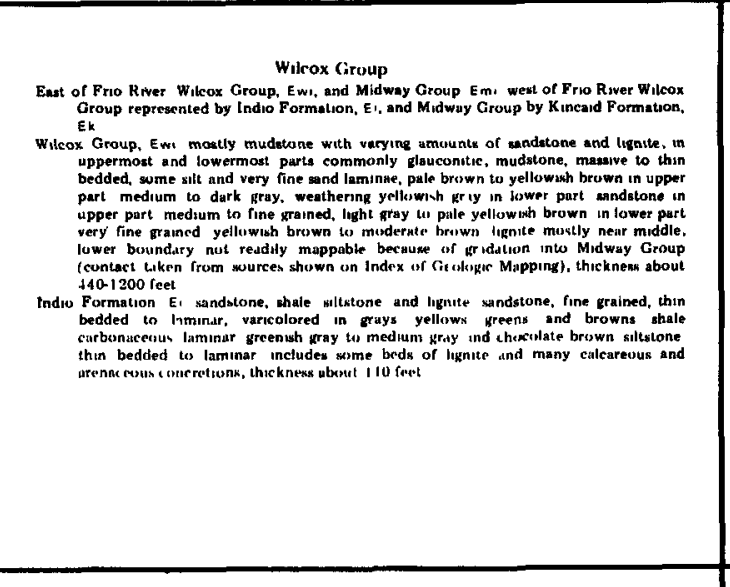 & $\begin{array}{rl}3 & =5 \\
3 & 3\end{array}$ & $=3$ & 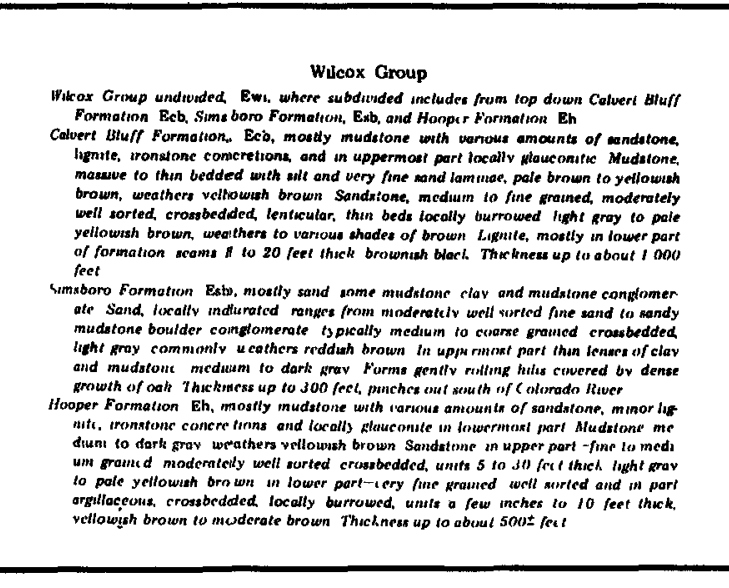 & 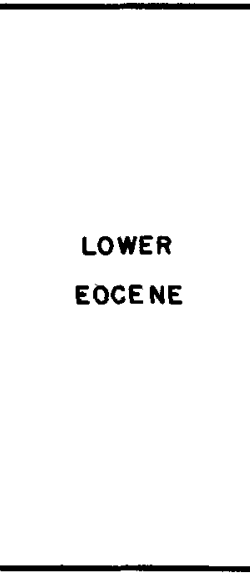 \\
\hline 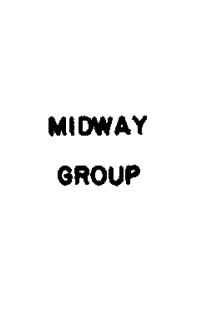 & & $5=5=5$ & 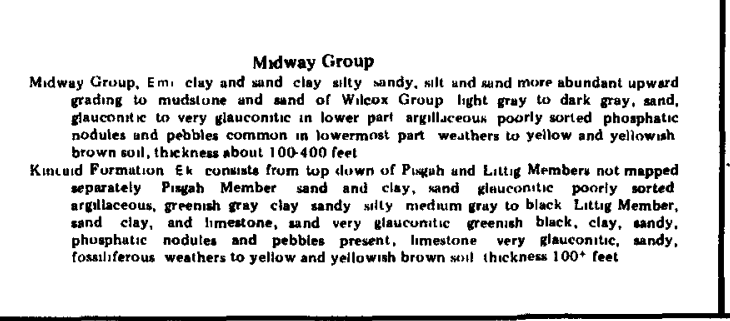 & 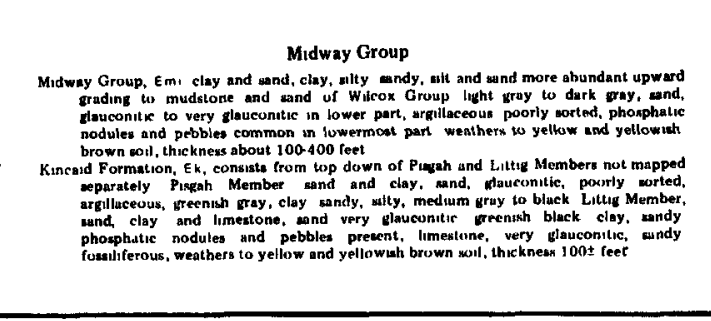 & $\begin{array}{ll}3.23 \\
3\end{array}$ & $y 3=3$ & PaAtecene \\
\hline
\end{tabular}









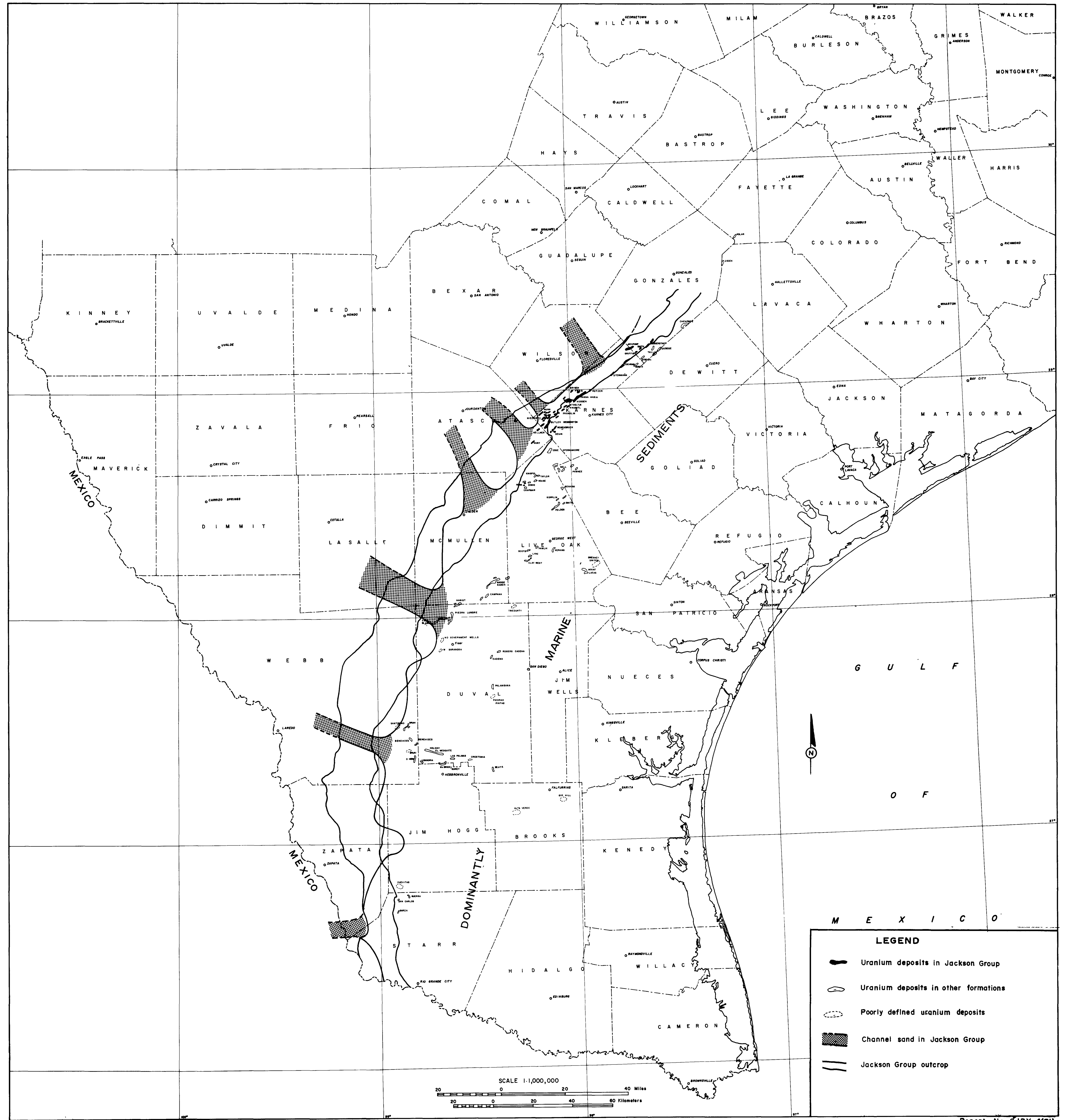









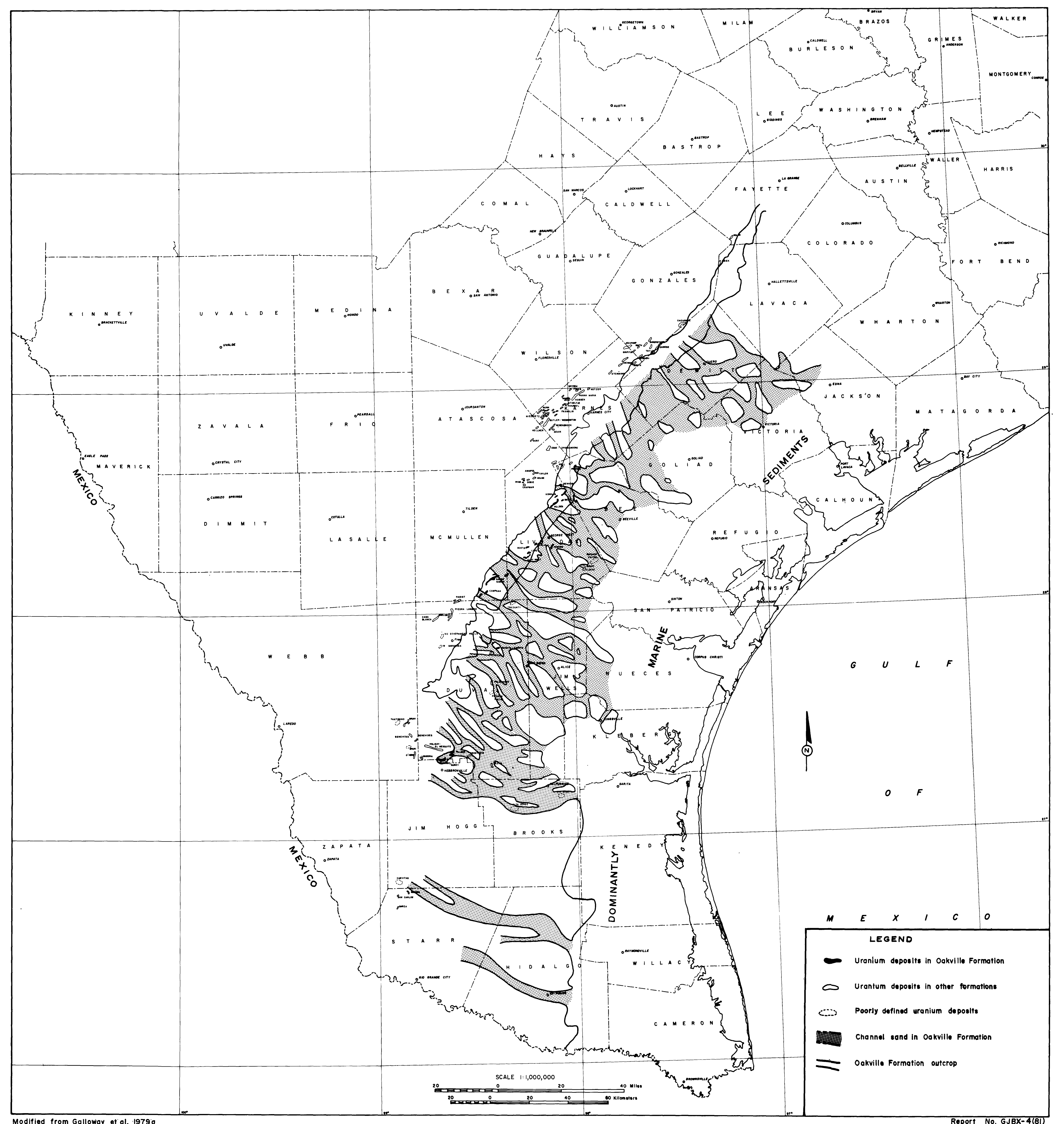




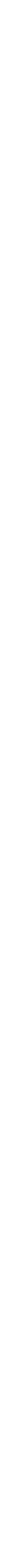




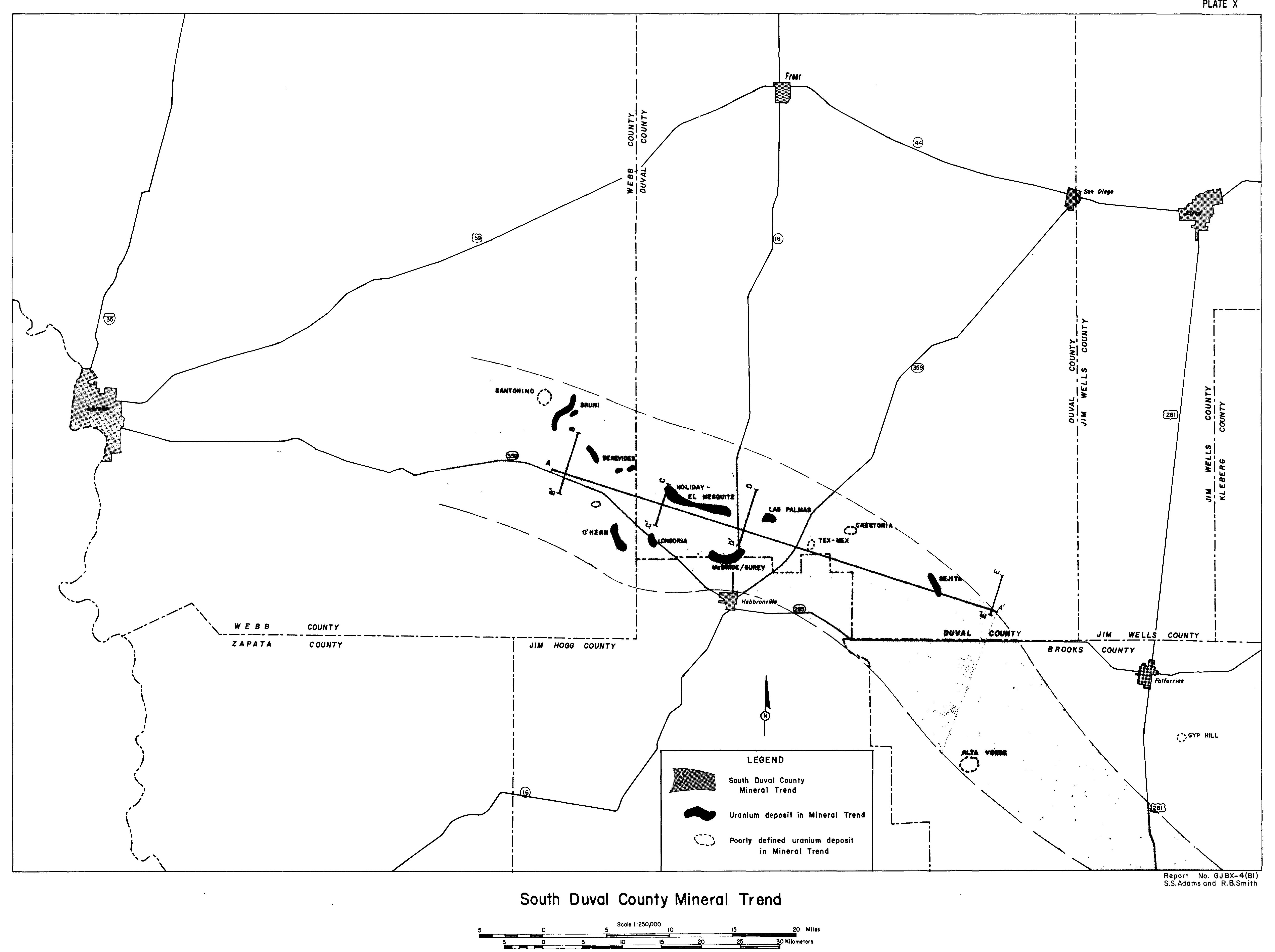










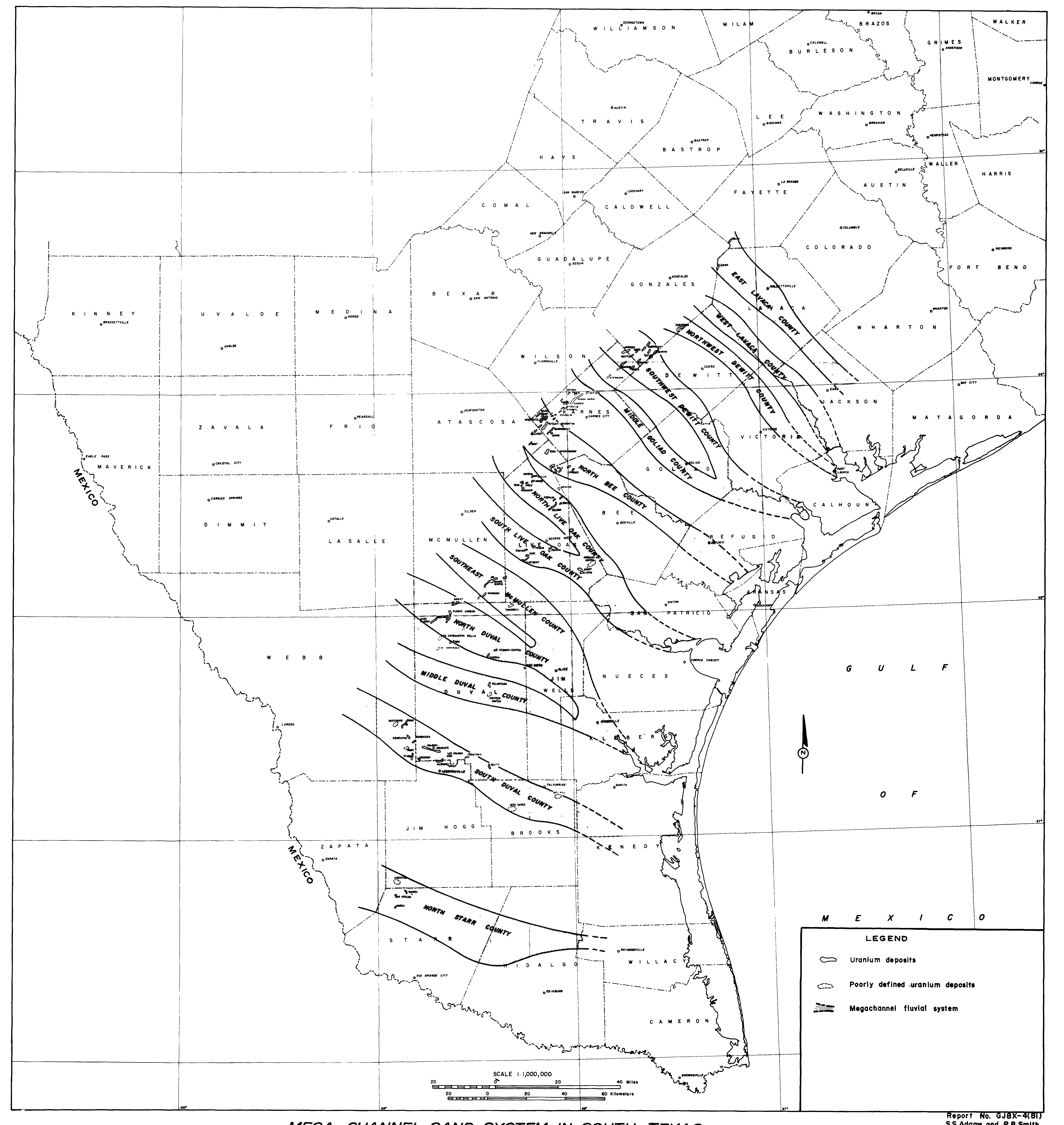

